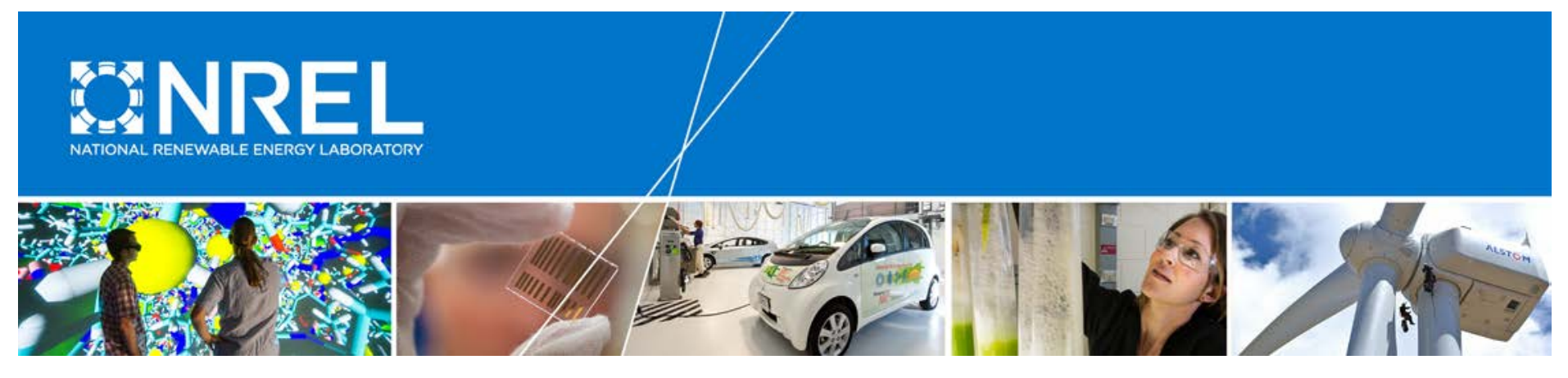

\title{
The Potential for Renewable Energy Development to Benefit Restoration of the Salton Sea: Analysis of Technical and Market Potential
}

Douglas Gagne, Scott Haase, Brett Oakleaf, David Hurlbut, Sertac Akar, Anna Wall, Craig Turchi, Philip Pienkos, Jennifer Melius, and Marc Melaina

National Renewable Energy Laboratory

NREL is a national laboratory of the U.S. Department of Energy Office of Energy Efficiency \& Renewable Energy Operated by the Alliance for Sustainable Energy, LLC

This report is available at no cost from the National Renewable Energy Laboratory (NREL) at www.nrel.gov/publications.

Technical Report

NREL/TP-7A40-64969

November 2015

Contract No. DE-AC36-08GO28308 


\section{The Potential for Renewable Energy Development to Benefit Restoration of the Salton Sea: Analysis of Technical and Market Potential}

Douglas Gagne, Scott Haase, Brett Oakleaf, David Hurlbut, Sertac Akar, Anna Wall, Craig Turchi, Philip Pienkos, Jennifer Melius, and Marc Melaina

National Renewable Energy Laboratory

Prepared under Task No. WWGG.1080

NREL is a national laboratory of the U.S. Department of Energy Office of Energy Efficiency \& Renewable Energy Operated by the Alliance for Sustainable Energy, LLC

This report is available at no cost from the National Renewable Energy Laboratory (NREL) at www.nrel.gov/publications.

National Renewable Energy Laboratory 15013 Denver West Parkway Golden, CO 80401

303-275-3000 • www.nrel.gov

\section{Technical Report}

NREL/TP-7A40-64969

November 2015

Contract No. DE-AC36-08GO28308 


\title{
NOTICE
}

This report was prepared as an account of work sponsored by an agency of the United States government. Neither the United States government nor any agency thereof, nor any of their employees, makes any warranty, express or implied, or assumes any legal liability or responsibility for the accuracy, completeness, or usefulness of any information, apparatus, product, or process disclosed, or represents that its use would not infringe privately owned rights. Reference herein to any specific commercial product, process, or service by trade name, trademark, manufacturer, or otherwise does not necessarily constitute or imply its endorsement, recommendation, or favoring by the United States government or any agency thereof. The views and opinions of authors expressed herein do not necessarily state or reflect those of the United States government or any agency thereof.

This report is available at no cost from the National Renewable Energy Laboratory (NREL) at www.nrel.gov/publications.

Available electronically at SciTech Connect http:/www.osti.gov/scitech

Available for a processing fee to U.S. Department of Energy and its contractors, in paper, from:

\author{
U.S. Department of Energy \\ Office of Scientific and Technical Information \\ P.O. Box 62 \\ Oak Ridge, TN 37831-0062 \\ OSTI http://www.osti.gov \\ Phone: 865.576.8401 \\ Fax: 865.576.5728 \\ Email: reports@osti.gov
}

Available for sale to the public, in paper, from:

\author{
U.S. Department of Commerce \\ National Technical Information Service \\ 5301 Shawnee Road \\ Alexandria, VA 22312 \\ NTIS http://www.ntis.gov \\ Phone: 800.553 .6847 or 703.605 .6000 \\ Fax: 703.605.6900 \\ Email: orders@ntis.gov
}




\section{Foreword}

The Salton Sea and the surrounding region face a wide range of environmental concerns from reduced inflows and other environmental factors, including exposed, potentially emissive lake beds; rising salinity; and impacts to aquatic and migratory avian species. A restoration program is urgently needed to address these concerns. Funded through a grant from the State of California Natural Resources Agency, under Agreement No. 0540-SSA 1, the Salton Sea Authority (SSA) is preparing the Salton Sea Funding and Feasibility Action Plan to address this need.

The broad goal of the Salton Sea Funding and Feasibility Action Plan is to develop an updated vision for the Salton Sea and surrounding region that matches funding realities with needs. The project has three specific goals:

- Provide a healthy environment for residents around the Salton Sea

- Work toward a Salton Sea and bordering habitat that sustains enough aquatic life to provide habitat for wildlife on the Pacific flyway

- Help revitalize the economy around the Salton Sea and in Imperial and Riverside Counties.

Goals and objectives for the project can be divided into the following categories: planning and engineering, environmental, and financing and feasibility which includes evaluating land development options and alternative energy sources. The restoration program is divided into seven benchmarks: 1) Work Plan, 2) Data Compilation, 3) Alternatives Evaluation, 4) Conceptual Plans, 5) Funding Evaluation from Real Estate Development Sources, 6) Funding Evaluation from Renewable Energy Sources, and 7) Final Report.

The Authority retained Tetra Tech to serve as the prime contractor to help complete the plan. Tetra Tech's subcontractor, the National Renewable Energy Laboratory (NREL), was retained to prepare a report analyzing the potential of various renewable energy technologies to financially contribute to Salton Sea restoration efforts in partial completion of benchmark 6 .

In 2013, the Imperial Irrigation District commissioned a preliminary study on the potential for renewable energy projects in the Salton Sea region to partially fund the restoration of the Salton Sea. This feasibility study examined the revenue potential from renewable energy project development in the Imperial Valley and estimated that roughly $\$ 4.1$ billion might be realizable over the study period of 2016 to 2045 . This study specifically seeks to confirm and refine these prior revenue potential estimates, provide a technical review of the renewable energy technologies under consideration, and develop estimates of the region's developable production potential through the year 2030 . 


\section{Acknowledgments}

This work is made possible through and in support of the goals of the State of California, Tetra Tech, and the Salton Sea Authority. The authors would like to thank the interest and support of the many contributors to this report, including: the U.S. Department of Energy, Imperial Irrigation District, Imperial and Riverside Counties, the U.S. Bureau of Reclamation, the California Natural Resources Agency, the California Public Utilities Commission, and the Los Angeles Department of Water and Power. Additional thanks to NREL contributors Connie Komomua, Erik Ness, Anelia Milbrandt, Niall O’Connor, and Nick Grue for their invaluable support of the project. 


\section{List of Acronyms}

\begin{tabular}{|c|c|}
\hline $\mathrm{AC}$ & alternating current \\
\hline APS & Arizona Public Service \\
\hline a-Si & amorphous silicon \\
\hline ASTER & Advanced Spaceborne Thermal Emission and Reflection Radiometer \\
\hline BLM & Bureau of Land Management \\
\hline BWRO & brackish water reverse osmosis \\
\hline CAISO & California Independent System Operator \\
\hline CARB & California Air Resources Board \\
\hline $\mathrm{CCNG}$ & combined cycle natural gas generator \\
\hline $\mathrm{CdTe}$ & cadmium telluride \\
\hline CIGS & copper indium gallium selenide \\
\hline $\mathrm{CO} 2$ & carbon dioxide \\
\hline CPUC & California Public Utility Commission \\
\hline CPV & concentrating photovoltaics \\
\hline CSP & concentrating solar power \\
\hline DC & direct current \\
\hline DOE & U.S. Department of Energy \\
\hline DRECP & Desert Renewable Energy Conservation Plan \\
\hline $\mathrm{DSC}$ & dye-sensitized solar cell \\
\hline EHV & extra-high voltage \\
\hline EIM & energy imbalance market \\
\hline EISA & Energy Independence and Security Act \\
\hline EPA & Environmental Protection Agency \\
\hline EPAct 2005 & Energy Policy Act of 2005 \\
\hline FCEV & fuel cell electric vehicles \\
\hline GEA & Geothermal Energy Association \\
\hline gge & gallons gasoline equivalent \\
\hline ggm & gallons per minute \\
\hline GHG & greenhouse gas \\
\hline GIS & geographic information system \\
\hline gpm & gallons per minute \\
\hline GW & gigawatt \\
\hline GWh & gigawatt hour \\
\hline HTF & heat-transfer fluid \\
\hline IID & Imperial Irrigation District \\
\hline IOU & investor-owned utility \\
\hline IRP & integrated resource plans \\
\hline ITC & investment tax credit \\
\hline $\mathrm{kg}$ & kilogram \\
\hline KGRA & known geothermal resource area \\
\hline LADWP & Los Angeles Department of Water and Power \\
\hline $\mathrm{LCOE}$ & levelized cost of energy \\
\hline LCZ & lower convective zone \\
\hline LDV & light-duty vehicles \\
\hline LH2 & liquid hydrogen \\
\hline MED & multi-effect distillation \\
\hline MLD & mineral leasing districts \\
\hline MMBTU & one million British Thermal Units \\
\hline MSF & multi-stage flash \\
\hline MT & magnetotelluric \\
\hline MW & megawatt \\
\hline
\end{tabular}




\begin{tabular}{|c|c|}
\hline MWh & megawatt hour \\
\hline NADB & North American Development Bank \\
\hline $\mathrm{NCZ}$ & non-convective zone \\
\hline NREL & National Renewable Energy Laboratory \\
\hline O\&M & operation and maintenance \\
\hline ORC & organic Rankine cycle \\
\hline PG\&E & Pacific Gas and Electric Company \\
\hline PILT & payments in lieu of taxes \\
\hline PPA & power purchase agreement \\
\hline ppm & parts per million \\
\hline PRODES & Promotion of Renewable Energy for Water Production through Desalination \\
\hline PV & photovoltaics \\
\hline QSA & Quantification Settlement Agreement \\
\hline R\&D & research and development \\
\hline $\mathrm{RD} \& \mathrm{D}$ & research, development, and demonstration \\
\hline REZ & renewable energy zones \\
\hline ROW & right-of-way \\
\hline RPM & Resource Planning Model \\
\hline RPS & renewable portfolio standard \\
\hline SCE & Southern California Edison \\
\hline SDG\&E & San Diego Gas and Electric \\
\hline SEBASS & Spatially Enhanced Broadband Array Spectrograph System \\
\hline SEZ & solar energy zones \\
\hline SGI & Synthetic Genomics, Inc. \\
\hline SGSP & salinity gradient solar ponds \\
\hline SMR & steam methane reforming \\
\hline SONGS & San Onofre Generating Station \\
\hline SRP & Salt River Project \\
\hline SSA & Salton Sea Authority \\
\hline SWRCB & State Water Resources Control Board \\
\hline SWRO & seawater reverse osmosis \\
\hline TDS & total dissolved solids \\
\hline TEP & Tucson Electric Power \\
\hline TES & thermal energy storage \\
\hline TRL & technology readiness level \\
\hline $\mathrm{UCZ}$ & upper convective zone \\
\hline USDA & U.S. Department of Agriculture \\
\hline USGS & United States Geological Survey \\
\hline WAPA & Western Area Power Administration \\
\hline WECC & Western Electricity Coordinating Council \\
\hline ZEV & zero emission vehicles \\
\hline
\end{tabular}




\section{Abstract}

This report summarizes the potential for renewable energy development in the Salton Sea region, as well as the potential for revenues from this development to contribute financially to Salton Sea restoration costs. Based on Tetra Tech estimates, the Salton Sea will recede most rapidly between 2020 and 2030, exposing roughly 30,000 acres of playa around the entire Salton Sea, of which approximately 11,000 acres will be exposed within the Salton Sea known geothermal resource area (KGRA). The exposed land within the KGRA is potentially available for development of geothermal projects, and the remaining land may be suitable for algal biomass, solar PV, salinitygradient solar ponds, or for construction of wetlands/habitat.

Key findings reveal the technical potential for the following:

- Geothermal development by 2030 is estimated at $1.05 \mathrm{GW}$ to $1.81 \mathrm{GW}$ of generation capacity.

- Solar photovoltaics and concentrating solar power is estimated at $1.8 \mathrm{GW}$ and $1.3 \mathrm{GW}$, respectively.

- Algal biomass potential is estimated at up to 40 million gallons of algal biofuel per year, or 600,000 tons of algal food and feed annually. Algal biomass development could potentially cover large tracts of exposed playa, absorb a portion of existing irrigation fertilizer runoff, and generate an additional revenue stream from biofuel sales.

- Potential mineral recovery of lithium from Salton Sea geothermal brines is estimated at 54,000 to 122,000 metric tons annually by 2030 , with significant uncertainty due to limited well data. Although no commercial geothermal brine mineral recovery projects exist currently, this technology has been verified as technically viable at pilot-plant scale in the Salton Sea KGRA.

The potential for an additional tax on generation to fund Salton Sea restoration is also examined. Based on analysis using the California Public Utilities Commission's Renewable Portfolio Standard (RPS) calculator, it appears that any "restoration adder" on generation located in the region could disadvantage the development of these resources in comparison to other regions. Any adder would need to reflect market conditions, as even the addition of a relatively small $\$ 5$ per megawatt-hour restoration charge to the cost of new Salton Sea renewable energy projects could make them significantly more expensive than competing alternatives in the regional supply pool.

The development of the renewable energy technologies examined within the report will generate local tax revenues, environmental mitigation fees, regional economic development from construction, geothermal royalty payments to the state and counties from development on BLM lands, and land lease revenues from development on Imperial Irrigation District-owned lands. Land lease revenues were the primary revenue stream examined. Under current conditions, if the amounts estimated in the report are fully developed by 2030, geothermal land lease royalties that could be usable for Salton Sea restoration would range between $\$ 7$ million- $\$ 15$ million annually, depending primarily on lease rates and power purchase agreement pricing. Additional revenue streams from development of renewable energy projects could potentially range from $\$ 5.6$ million to $\$ 77.8$ million annually, but are dependent on future changes in technology and policy conditions. 


\section{Executive Summary}

\section{Overview}

The U.S. Department of Energy's (DOE)

National Renewable Energy Laboratory

(NREL) conducted a comprehensive analysis

to evaluate the potential of various renewable energy technologies to financially contribute to the restoration of the Salton Sea.

In 2013, the Imperial Irrigation District (IID) commissioned a preliminary study on the potential for renewable energy projects in the Salton Sea region to partially fund the restoration of the Salton Sea. IID's feasibility study examined the revenue potential from land leases in the Imperial Valley for renewable energy projects, and estimated that roughly $\$ 4.1$ billion might be realizable over the study period of 2016 to 2045 .

This report, The Potential for Renewable Energy Development to Benefit Restoration of the Salton Sea: Analysis of Technical and Market Potential, specifically seeks to confirm and refine these prior revenue potential estimates, provide a technical review of the renewable energy technologies under consideration, and develop estimates of the region's developable production potential through the year 2030.

\section{The Salton Sea}

The Salton Sea, with a surface area of roughly 365 square miles, is the largest lake in California. It was created in 1905 when the Colorado River flooded, broke through diversion canals, and flowed freely into the Salton Basin for close to two years. By the time the break was fixed, the Salton Sea was created and became a popular recreational area for campers, boaters, and anglers.

\section{Salinity}

Water inflows from irrigation runoff bring several million tons of salt annually to the Salton Sea. There are no outflowing rivers or streams, so water primarily escapes through evaporation, leaving salt and other minerals behind. Over the years, the salinity of the Salton Sea has become higher than that of the nearby Pacific Ocean. While few fish species, with the exception of tilapia, have been able to survive, the Salton Sea surroundings have become an important wildlife habitat, home to North America's largest population of migratory waterfowl outside of the Everglades.

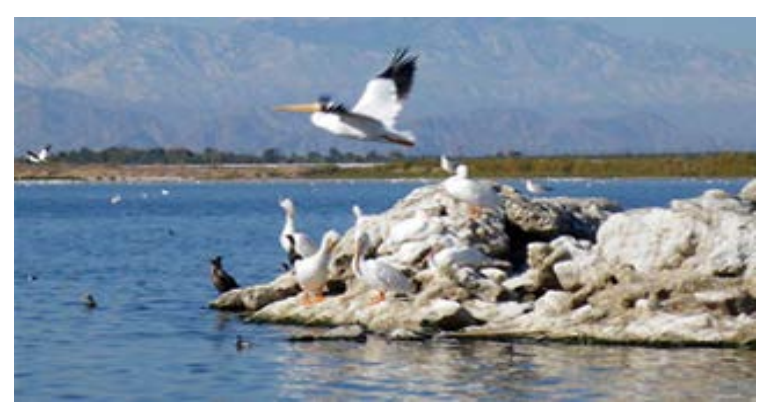

Figure ES-1: Salton Sea migratory birds.

\section{Drought}

California is undergoing a record-setting drought that began in 2012. Salton Sea agricultural and rainwater inflows have diminished and water conservation measures call for Colorado River water to be transferred from agricultural to urban use in San Diego and the Coachella Valley.

As a result, the water level of the sea is expected to fall significantly, leaving a dry and dusty lake bed, commonly called a playa. For the purposes of this report, playa exposed by the recession of the Salton Sea shore from 2010 levels will be defined as "offshore".

\section{Restoration}

The Salton Sea and the surrounding region face a wide range of environmental concerns from reduced inflows and other environmental factors, including exposed, potentially emissive lakebeds; rising salinity; and impacts to aquatic and migratory avian 
species. A restoration program is being explored to address these concerns. This report examines the potential for renewable energy resources to help fund long-term restoration efforts of the Salton Sea.

\section{Study Areas}

To identify the land available for renewable energy development in the Salton Sea study area, geographic information system methods were used to compile land use shapefiles from the multiple stakeholders in the region. The Desert Renewable Energy Conservation Plan (DRECP), Imperial County, Riverside County, Imperial Irrigation District, and the U.S. Bureau of Land Management (BLM) all contributed data to the analysis.

The Salton Sea Study Area is as follows:

- The national border with Mexico was established as the southern border.

- The northern and eastern borders were extended to the eastern extent of Riverside County in order to incorporate the BLM's Riverside East solar energy zone (SEZ).

- The western border was extended to roughly correspond to the DRECP.

- The Salton Sea playa was listed as a potentially developable area, although there is uncertainty concerning both the rate of recession and additional costs for development in this land area.

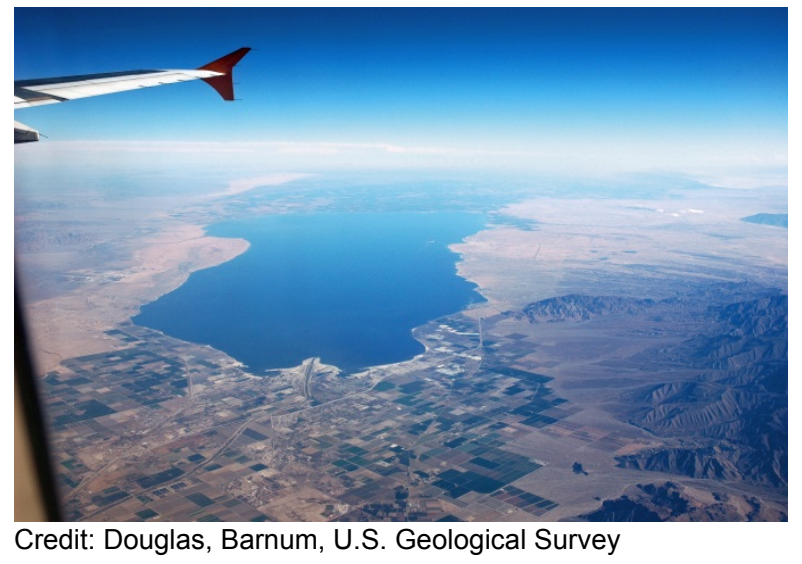

Figure ES-2: Looking south at the Salton Sea.
Within the Salton Sea study area, the southern half of the Salton Sea has been identified as the primary area of opportunity for significant development, primarily due to the presence of large tracts of potentially developable public and private land, existing and planned projects, and greater opportunity for future transmission export. This does not preclude development in other areas; potentially developable solar resources exist within the West Chocolate Mountains SEZ as well.

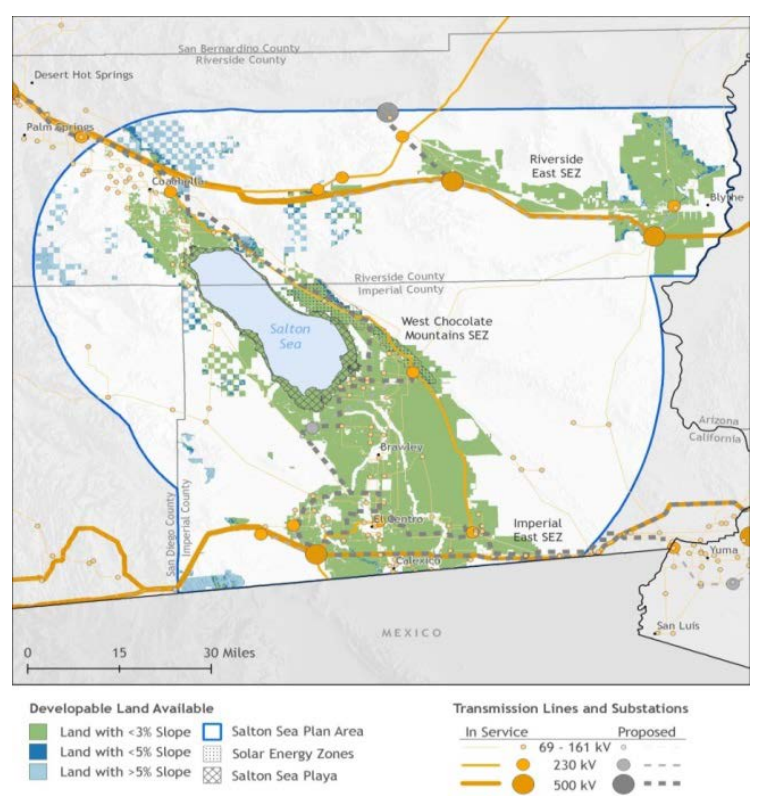

Figure ES-3: Total Developable Renewable Energy Land.

\section{Evaluations}

Technologies considered in this report are:

- Electricity production from geothermal

- Mineral recovery from geothermal fluids

- Electricity production from solar photovoltaics (PV), concentrating solar power (CSP), and salinity-gradient solar ponds (SGSP)

- Hydrogen production

- Biofuels and nutraceutical production from algae pond cultivation.

Wind is not evaluated in the report due to the minimal resource potential within the region. 
In addition to renewable energy technologies and their coproducts, desalination of the Salton Sea from renewable energy is also discussed as a potential benefit to restoration.

\section{Renewable Energy Potential}

Of the commercially available renewable energy technologies, geothermal, solar photovoltaics (PV) and concentrating solar power (CSP) have the greatest technical potential for development. The resource potential, costs, and estimated revenue streams from these technologies are summarized in Table ES-1.

\section{Constraints}

Market factors are the biggest constraint on development. Development on the playa itself will be constrained by the rate at which the shoreline recedes, and although playa may be exposed in a given year, there will likely be an additional lag in development due to variability in Salton Sea water levels and potentially muddy site conditions.

Despite the large total resource potential, constraints such as proximity to transmission access and regional cost-competitiveness of the electricity generated may limit the technical potential of the power generation technologies before 2030 .

Additionally, PV and CSP require between 5 and 10 acres per megawatt (MW), so larger scale projects over $20 \mathrm{MW}$ could be limited by the availability of contiguous land parcels.

Table ES-1. Salton Sea Renewable Energy Resource Potential and Costs

\begin{tabular}{|c|c|c|c|c|c|}
\hline Technology & $\begin{array}{l}\text { Land } \\
\text { Developable } \\
\text { by } 2030 \\
\text { (acres) }\end{array}$ & $\begin{array}{l}\text { Undeveloped } \\
\text { Energy } \\
\text { Resource } \\
\text { Potential }\end{array}$ & $\begin{array}{l}\text { Resource } \\
\text { Potential } \\
\text { Developable } \\
\text { by } 2030\end{array}$ & $\begin{array}{l}\text { Current } \\
\text { levelized- } \\
\text { cost } \\
(\$ / \mathrm{MWh})^{* * *}\end{array}$ & $\begin{array}{l}\text { Estimated } \\
\text { levelized-cost } \\
\text { in } 2030 \\
(\$ / M W h)^{* * *}\end{array}$ \\
\hline $\begin{array}{l}\text { New Geothermal } \\
\text { power }\left(K_{\left.G R A^{*}\right)}\right.\end{array}$ & 50,330 & $\begin{array}{l}1.78 \mathrm{GW}- \\
2.94 \mathrm{GW}\end{array}$ & $1.05-1.81 \mathrm{GW}$ & $\$ 107-\$ 131$ & $\$ 107-\$ 131$ \\
\hline $\begin{array}{l}\text { Mineral recovery } \\
\text { from geothermal } \\
\text { brines (KGRA) }\end{array}$ & 50,330 & $\begin{array}{l}115-222 \\
\text { thousand MT } \\
\text { Lithium }\end{array}$ & $\begin{array}{l}54.3-122 \\
\text { thousand MT } \\
\text { Lithium }\end{array}$ & $\begin{array}{l}\text { Not } \\
\text { commercial }\end{array}$ & Not available \\
\hline $\begin{array}{l}\text { Onshore Solar } \\
\text { PV }\end{array}$ & 14,405 & $31.9 \mathrm{GW}$ & $1.8 \mathrm{GW}$ & $\$ 100-\$ 113$ & $\$ 49-\$ 94$ \\
\hline $\begin{array}{l}\text { Offshore Solar } \\
\text { PV }\end{array}$ & 9,938 & $4.2 \mathrm{GW}$ & $1.25 \mathrm{GW}$ & $\$ 100-\$ 113^{* *}$ & $\$ 49-\$ 94^{* *}$ \\
\hline Onshore CSP & 13,147 & $23.9 \mathrm{GW}$ & $1.3 \mathrm{GW}$ & $\$ 181$ & $\$ 84-\$ 132$ \\
\hline $\begin{array}{l}\text { Offshore Algal } \\
\text { Biofuels }\end{array}$ & 32,821 & $39 \mathrm{M}$ gal/year & $\begin{array}{l}\text { Not } \\
\text { commercial }\end{array}$ & $\$>10 /$ Gallon & \$3/gallon \\
\hline $\begin{array}{l}\text { Offshore } \\
\text { Salinity-Gradient } \\
\text { Solar Ponds }\end{array}$ & 9,938 & $0.444 \mathrm{GW}$ & $.1 \mathrm{GW}$ & $\$ 80-110$ & Not available \\
\hline
\end{tabular}

${ }^{*}$ Known geothermal resource areas, ${ }^{* *}$ offshore playa construction requirements may result in higher LCOE,

${ }^{* * *}$ Exclude state and federal incentives, but are inclusive of MACRS depreciation. Deal provisions, such as: escalation rate, ITC, term length, state income and sales tax rates, project financing, and additional grid services can all result in a disparity between the LCOE and ultimate PPA price of a technology. 
Assumptions and Conditions in Table ES-1

- The figures for geothermal power and mineral recovery include the developable land within the KGRAs for reference, but the resource potentials are solely calculated based on volumetric assessments of the geothermal resource.

- The figures for PV and CSP refer to developable land and resource potential within one mile of $138 \mathrm{kV}$ to $230 \mathrm{kV}$ transmission access, excluding the land within the KGRAs.

- The undeveloped potential for PV and CSP refers to developable land and resource potential within five miles of $138 \mathrm{kV}$ to $230 \mathrm{kV}$ transmission access.
- Resource potentials are mutually exclusive; developing a CSP system on a piece of land would preclude installing $\mathrm{PV}$ on the same piece of land.

- The underlying data set used for cost estimates in this report is the NREL Annual Technology Baseline and Standard Scenarios.

- The cost assumptions do not reflect state or federal incentives, such as the investment tax credit, but are inclusive of Modified Accelerated Cost Recovery System (MACRS) depreciation.

- Specific cost-related assumptions can be found in Appendix B of the full report.

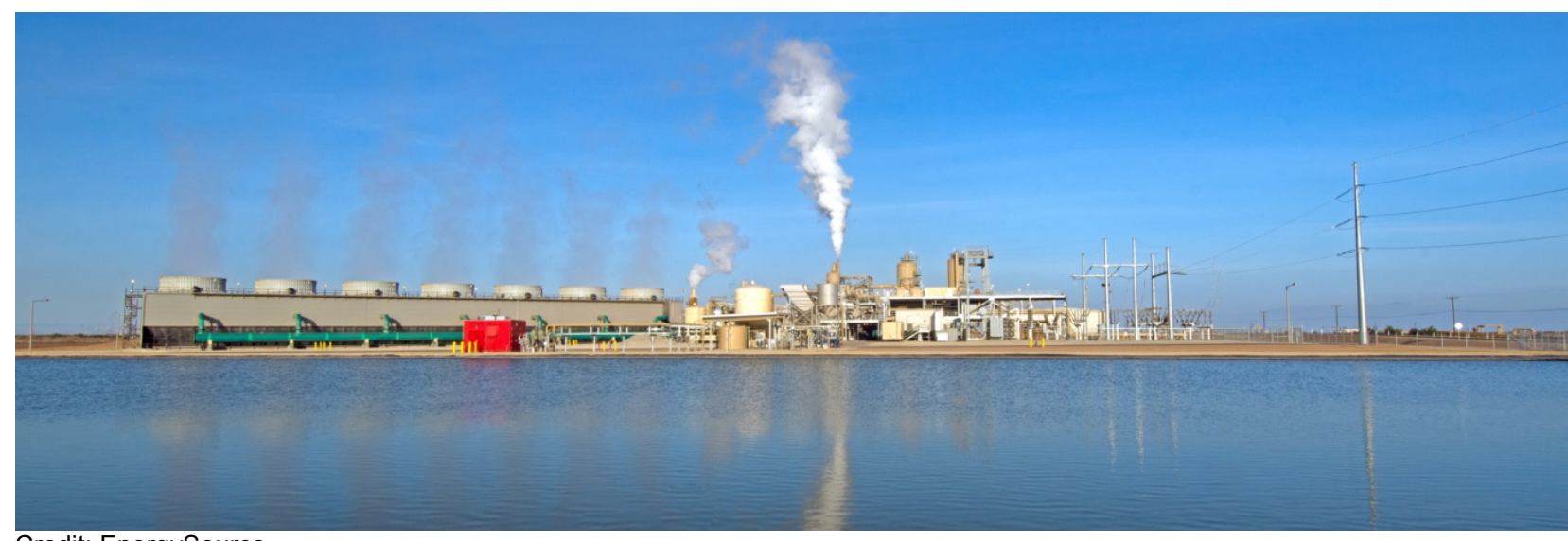

Credit: EnergySource

Figure ES-4: A geothermal plant on the Salton Sea.

\section{Geothermal}

The Salton Sea area has exceptional geothermal resources, with one of the largest geothermal anomalies in the United States located at the southern end of the Sea in Imperial County.

\section{Electricity Production}

There are roughly 232,000 acres of developable land within the various Imperial County KGRAs, of which 1,851 acres lie within 1 mile of a $138 \mathrm{kV}$ to $230 \mathrm{kV}$ substation. Approximately 50,000 acres lie within 5 miles of a $138 \mathrm{kV}$ to $230 \mathrm{kV}$ substation, which could allow for future geothermal development. Additionally, geothermal power plants have relatively small footprints; thus constructed wetlands, algae farms, and renewable energy projects could be interspersed with geothermal plants within the KGRA. An additional benefit of geothermal development is that infrastructure such as roads and berms will be created and can then be utilized by other projects.

The technical potential for geothermal development is constrained by both the availability of surface land area, as well as the 
underlying geothermal resource. For the purposes of this analysis, the required surface area is assumed to be available, and the technical potential is determined through volumetric resource estimates of the underlying reservoir. Using this volumetric resource assessment method, the maximum remaining developable geothermal capacity by 2030 within this area is roughly 1,800 MW. However, the Salton Sea KGRA comprises 1,350 MW of this capacity, and much of that resource is still under water within the Salton Sea.

Although the offshore resource is not currently accessible, Tetra Tech provided water recession forecasts that were used to estimate that $370 \mathrm{MW}$ to $570 \mathrm{MW}$ of the offshore resource could be developable by 2030.

\section{Mineral Recovery}

Mineral recovery of lithium from Salton Sea geothermal brines could potentially produce up to $\$ 860$ million annually in total business revenues, with up to $\$ 25.8$ million going to IID via annual royalties of $3 \%$ on gross revenues. For a high-temperature $50 \mathrm{MW}$ geothermal power plant, mineral recovery of lithium at current market prices could yield $\$ 91$ to $\$ 118$ million in annual revenues. This is a nascent technology and revenue estimates are highly uncertain because: 1) the cost structure of such mineral recovery operations may not be adequate to encourage businesses to enter the market, and 2) the degree to which potential increases in demand for lithium-based products may outstrip supply and impact market prices.

\section{Solar Technologies}

Given the generally strong solar resource in the Salton Sea area, a variety of solar electric or solar thermal technologies may be suitable for development within the region. However, note that because both $\mathrm{PV}$ and CSP require similar conditions, developing a CSP system on a piece of land would preclude installing PV systems on the same piece of land.

Although electricity production from salinitygradient solar ponds has been technically proven, it has not been established in the U.S. as an economically viable power production technology to date. The low-grade heat produced by this technology may also be supplied to other processes, including: desalination, algae pond heating, food processing, and other industrial processes.

\section{Solar Photovoltaics}

There are 815,271 acres in the Salton Sea study area with less than 5\% slope that could potentially accommodate $103 \mathrm{GW}$ of PV generation. Within this area, 14,405 acres lie within 1 mile of $138 \mathrm{kV}$ to $230 \mathrm{kV}$ transmission access and could accommodate $1.8 \mathrm{GW}$ of $\mathrm{PV}$, which is a conservative estimate of the resource that could be developable by 2030. Although the total capacity potential is extremely large, the developable potential is significantly smaller, due to proximity to transmission, land access, financing, and utility demand, among others.

\section{Concentrating Solar Power}

There are 771,656 acres in the Salton Sea study area with less than $3 \%$ slope, which could potentially accommodate $77 \mathrm{GW}$ of CSP. Within this area, 13,147 acres lie within 1 mile of $138 \mathrm{kV}$ to $230 \mathrm{kV}$ transmission access which could accommodate $1.3 \mathrm{GW}$ of CSP.

Due to the strong solar resource and relatively low slope constraints, there is a very high technical potential for CSP projects in the Salton Sea study area. However, as was noted in the solar PV section, while this capacity may be technically feasible, CSP development is also constrained by numerous other factors, including its relative economic competitiveness and potential avian impacts. 
Capacity factors for CSP technologies vary widely, with a range between $25 \%$ and $49 \%$.

\section{Salinity-Gradient Solar Ponds}

The total salinity-gradient solar pond (SGSP) resource potential in this area is estimated to be $444 \mathrm{MW}$, based on 26,628 acres of potential playa within 1 mile of transmission, and an assumed power density of 60 acres/MW. The current cost of power from SGSP is estimated to be within the range of $\$ 80-\$ 110 / \mathrm{MWh}$, but the technology is still nascent, making predictions about the likely cost in 2030 subject to significant uncertainty.

Given that SGSP projects have not yet been developed within the region, $100 \mathrm{MW}$ was estimated to be technically developable by 2030, although this does not account for transmission or economic viability, which are still uncertain.

\section{Hydrogen Production}

Hydrogen can be produced by reforming natural gas or splitting water molecules using any primary energy resource, including the resources abundant in the Salton Sea region.

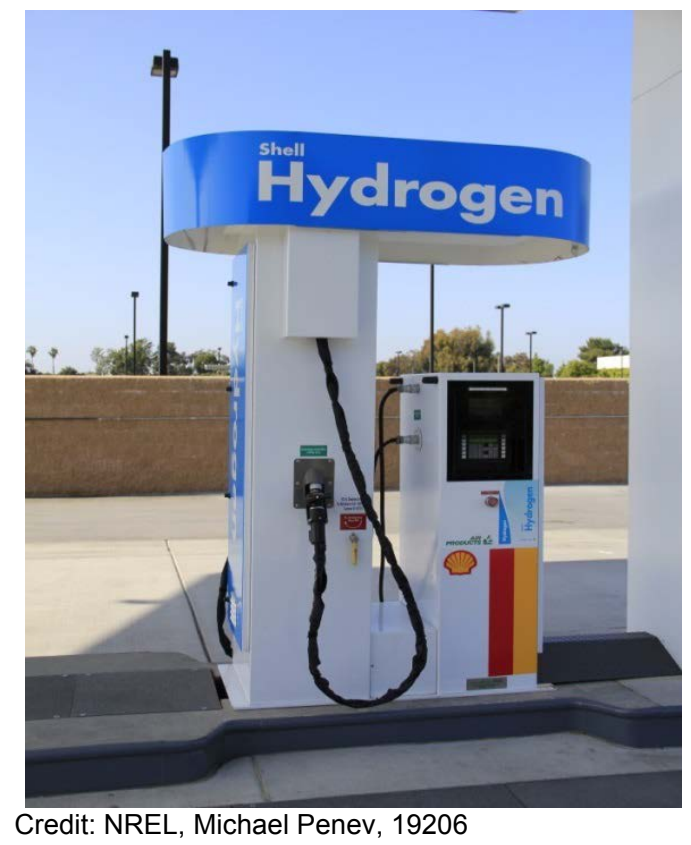

Figure ES-5: The first hydrogen fueling station, Los Angeles, CA.
California has several policies in place to accelerate the adoption of hydrogen fuel cell electric vehicles (FCEV). The biggest market for FCEVs is expected to be Los Angeles, which currently leads California in hydrogen station installations. However, the Salton Sea is 150 miles from Los Angeles, with transportation/delivery costs adding significantly to the cost of the delivered hydrogen compared to facilities operating closer to the city, and there are considerable uncertainties surrounding the rate at which FCEVs might be deployed.

Current projections are that the total number of FCEVs in California might be roughly 18,500 by 2020 . Based on projected FCEV adoption rates and due to the comparatively low cost of natural gas, it does not appear likely that hydrogen from the Salton Sea region would be competitive in the Los Angeles market until at least 2030.

\section{Algae Pond Cultivation}

Strains of algae have been identified that can grow in brackish, saline, and even hypersaline water.

\section{Biofuels}

The study area appears to be a favorable region for development of algal biomass resources due to the presence of large volumes of highly saline water, large tracts of unused playa and high insolation.

Algal ponds offer similar benefits as solar ponds to the local environment: covering the recently exposed soil and thereby reducing the potential for dust emissions. There are currently 32,821 acres of total developable land on the playa (unconstrained by transmission access), which could produce roughly 39 million gallons of biofuels per year.

Current costs are roughly \$17/gallon and would need to decrease substantially for this 
technology to be viable. Algal biofuel production is still pre-commercial and is unlikely to be cost-competitive with crude oil by 2030 , barring the implementation of Renewable Fuel Standards for algal biofuel consumption.

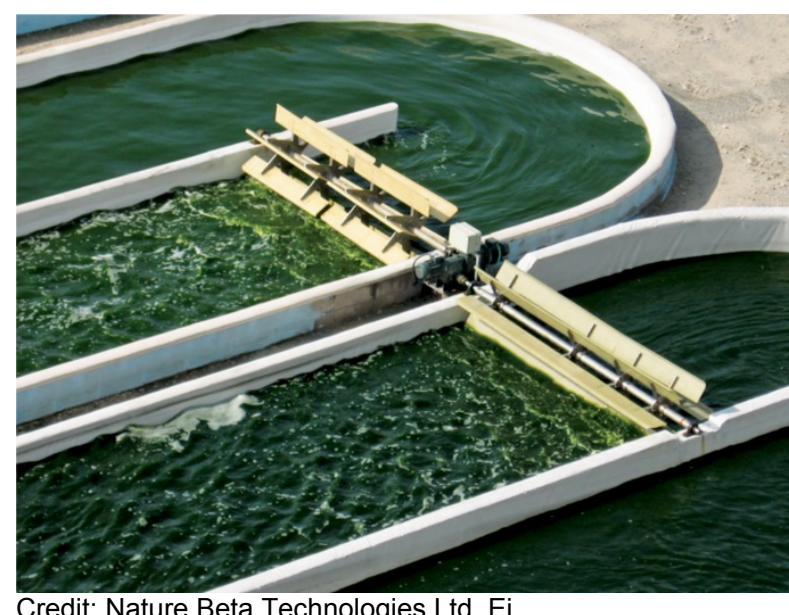

Figure ES-6: Algae raceway ponds; Largescale algae biomass production

\section{Nutraceuticals}

The production of cosmetic and dietary products, such as beta-carotene or spirulina, is commercial at scale, with operating plants in numerous countries. Notably, Synthetic Genomics, Inc. performs research and development and test-scale operations near the southern tip of the Salton Sea, and has been consulted concerning the feasibility of further development of algal ponds for nutraceutical products on the exposed Salton Sea playa. Further study of the Salton Sea's water quality is required, but development of an algal biomass pilot plant on exposed Salton Sea playa could verify whether this technology is viable in the region.

\section{Desalination}

In addition to the potential of renewable energy technologies and their coproducts to financially contribute to the restoration of the Salton Sea, the added benefit these technologies could bring to the high salinity levels of the Salton Sea was explored.
Desalination from renewable energy could provide a significant potential benefit to Salton Sea restoration efforts by feeding desalinated water back into the Sea and addressing the increasing salinity problem directly. Although this method is technically feasible, there is a cost, and returning fresh water to the Sea at zero or near-zero cost requires an alternative source of revenue for the process, such as salt sales.

The type of energy required is a pivotal consideration when considering renewableenergy powered desalination. Wind or Solar PV could be used to power an all-electric desalination process, although accommodation would have to be made for fluctuation in the resource. From a technical perspective, batteries can be added, but this is unlikely to be economically attractive.

The more interesting case for renewable energy desalination in the Salton Sea region is the potential to use geothermal or solar thermal energy with a thermal-desalination process. The benefit of this approach is that the process can be designed to run $24 / 7$ for smoother operation of the desalination treatment process. In the case of geothermal, such high availability is routine. For solar thermal, storage of the solar heat transfer fluid could be incorporated to separate solar collection from energy use and ensure a much higher availability.

Currently, there appears to be one desalination company operating by the Salton Sea. Several pilot-scale projects have operated on the edge of the Salton Sea, with a combined capacity of approximately 25,000 gal/day. These plants currently rely on low temperature steam provided by adjacent geothermal plants, but could also potentially utilize low-grade heat from salinity gradient solar ponds in the future. 


\section{Economic Outlook}

Table ES-2 summarizes potential mitigation revenues under current policy and technology conditions within the Salton Sea region. The development of geothermal and solar projects will generate tax revenues, environmental mitigation fees, regional economic development, geothermal royalty payments from development on BLM lands, and land lease revenues from development of IIDowned playa for Salton Sea development from power generation projects.

Estimated restoration revenue streams in previous studies have typically assumed that development in the Salton Sea region is sufficiently attractive from an economic standpoint to absorb the additional impact of a restoration charge on a project's cash flows while still providing a regionally competitive return on investment. However, based on modeling of potential scenarios, it has been determined that any additional tax on generation to support Salton Sea restoration may disadvantage the development of these resources relative to other renewable resources in the region.

Any added tax would need to reflect market conditions, as even the addition of a relatively small \$5 per megawatt-hour restoration charge to the cost of new Salton Sea geothermal projects could make them significantly more expensive than competing alternatives in the regional supply pool.

Similarly, a \$5/MWh charge for solar could result in the area's best resources becoming more expensive than competing projects. As modeled in the CPUC RPS Calculator, the area's solar resources could slip by about 7 percentage points in competitiveness in the California renewable energy supply curve, meaning that $49,000 \mathrm{GWh}$ of competing projects may become economically superior. For context, the modeled incremental demand from increasing California's RPS to $50 \%$ may be between 44,000 GWh and 74,000 GWh.

Table ES-2. Summary of Potential Mitigation Revenues under Current Conditions

\begin{tabular}{|c|c|c|}
\hline & $\begin{array}{c}\text { Current } \\
\text { Conditions } \\
\text { [Annual } \\
\text { Millions] }\end{array}$ & Notes: See Appendix C for full calculations \\
\hline Geothermal (KGRA)* & $\$ 7$ to 15 & $\begin{array}{l}\text { Onshore: BLM land lease royalties: } \$ 1-3 \\
\text { Offshore: IID land lease royalties : } \$ 6-12\end{array}$ \\
\hline Solar PV (onshore) & $\$ 0$ & \multirow{2}{*}{$\begin{array}{l}\text { Available onshore land is predominantly private, and } \\
\text { BLM Solar Energy Zone royalties are currently fully } \\
\text { allocated to the U.S. Treasury. }\end{array}$} \\
\hline CSP (onshore) & $\$ 0$ & \\
\hline \multicolumn{3}{|r|}{ 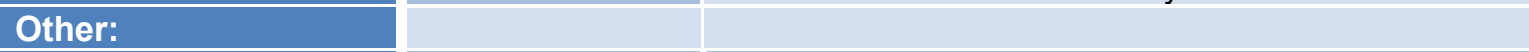 } \\
\hline $\begin{array}{l}\text { AB } 1471 \text { (CA } 2014 \\
\text { Water Bond) }\end{array}$ & $\$ 0$ to 14.3 & $\begin{array}{l}\text { Total CA water bond is } \$ 475 \mathrm{M}, \$ 200 \mathrm{M} \text { assumed as } \\
\text { upper limit given other obligations. }\end{array}$ \\
\hline Total (annual): & $\$ 7$ to 29.3 & $\begin{array}{l}\text { Annual revenues calculated assuming } 14 \text { years, } \\
\text { from } 2016-2030 \text {. Figures do not account for inflation } \\
\text { or the time value of money. }\end{array}$ \\
\hline 14 year total: & $\$ 98$ to 410.2 & $\begin{array}{l}\text { Note: The mitigation revenues in Tables ES- } 2 \text { and } \\
\text { ES-3 are additive. }\end{array}$ \\
\hline
\end{tabular}

* Geothermal projects should be given first priority for development on the KGRA, but due to their small overall footprint once projects are established, this acreage may be developable for other technologies as well. 
This might not be significant under scarcity conditions, but it could be a major handicap in a market characterized by large surpluses. There are some options, such as streamlined permitting or partnership with the North American Development Bank, that could be explored to improve the economic competitiveness of Salton Sea renewables such that they might be able to absorb a restoration tax while still remaining attractive to nearby power markets. However, in general developers are opposed to the concept of a restoration adder.

\section{Future Revenue Potential}

There is potential for greater demand for renewable energy beyond 2030, driven by California policy, such as AB 32, which calls for $80 \%$ greenhouse gas reductions below
1990 levels by 2050 and the recent passage of the 50\% RPS target. However, with indications of minimal economic headroom for a Salton Sea restoration tax on renewable energy development in the region between 2015 and 2030, additional potential revenue generation mechanisms for the Salton Sea Authority were explored. The primary revenue potential mechanism examined was land lease royalties, as these are existing costs associated with development that would be less likely to disadvantage projects' regional cost-competitiveness. Table ES-3 summarizes these potential revenues in 2016 through 2030. Although there may be between $\$ 78.4$ million and $\$ 1.09$ billion in potential revenues, additional sources of revenues will still be required to fund the proposed restoration options ( $\$ 2.3$ billion to $\$ 8.9$ billion).

Table ES-3. Summary of Potential Mitigation Revenues under Future Conditions

\begin{tabular}{|c|c|c|}
\hline & $\begin{array}{l}\text { Potential Future } \\
\text { Conditions } \\
\text { [Annual Millions] }\end{array}$ & Notes: See Appendix C for full calculations \\
\hline $\begin{array}{l}\text { Mineral recovery from } \\
\text { geothermal brines } \\
\text { (offshore KGRA) } \\
\end{array}$ & $\$ 0$ to 25.8 & $\begin{array}{l}\text { Assumes offshore development of up to } 570 \mathrm{MW} \text { of } \\
\text { geothermal, } 3 \% \text { IID royalty rate on gross lithium sales }\end{array}$ \\
\hline $\begin{array}{l}\text { Algal biofuels } \\
\text { (offshore non-KGRA)* }^{*}\end{array}$ & $\$ 1.2$ to 2.3 & $\begin{array}{l}\text { Assumes } \$ 3 / \text { gal cost competiveness by } 2030,1-2 \% \text { IID } \\
\text { land lease rate on gross proceeds. }\end{array}$ \\
\hline $\begin{array}{l}\text { Salinity Gradient Solar } \\
\text { Ponds } \\
\text { (offshore non-KGRA)* }^{\text {(off }}\end{array}$ & $\$ 0.6$ to 1.6 & $\begin{array}{l}\text { Assumes } \$ 80-\$ 100 / M W h \text { PPA, } 90 \% \text { capacity factor, } \\
\text { IID land lease rate }(1-2 \% \text { - gross proceeds). }\end{array}$ \\
\hline $\begin{array}{l}\text { Solar PV } \\
\text { (offshore non-KGRA)* }\end{array}$ & $\$ 1$ to 3 & $\begin{array}{l}\text { Assumes } \$ 40-60 / \mathrm{MWh} \text { PPA, } 23.2 \% \text { capacity factor, IID } \\
\text { land lease rate }(1-2 \% \text { - gross proceeds). }\end{array}$ \\
\hline $\begin{array}{l}\text { Solar PV (onshore BLM } \\
\text { Solar Energy Zones) }\end{array}$ & $\$ 1.5-4.4$ & $\begin{array}{l}\text { Assumes passage of S-1407and development of } 1.8 \\
\text { GW of BLM SEZ's. Assumes } \$ 40-60 / \text { MWh PPA, } 23.2 \% \\
\text { capacity factor, royalty rate between } 1-2 \% \text { of gross } \\
\text { proceeds. }\end{array}$ \\
\hline \multicolumn{3}{|l|}{ Other: } \\
\hline $\begin{array}{l}\text { Desert Renewable } \\
\text { Energy Conservation } \\
\text { Plan - Habitat } \\
\text { Restoration } \\
\end{array}$ & $\$ 3.5$ to $\$ 44.6$ & $\begin{array}{l}\text { Lower case based on allocable revenues to desert } \\
\text { pupfish habitat, upper case is for full habitat restoration } \\
\text { amounts for Imperial \& Riverside Counties }\end{array}$ \\
\hline Total (annual): & $\$ 5.6$ to 77.8 & \multirow{2}{*}{$\begin{array}{l}\text { The potential revenues above typically require a } \\
\text { change in policy, development of the offshore playa, or } \\
\text { technological developments. }\end{array}$} \\
\hline 14 year total: & $\$ 78.4$ to $1,089.2$ & \\
\hline \multicolumn{3}{|c|}{$\begin{array}{l}\text { * The potential development of off-shore acreage outside of the KGRA is mutually exclusive. e.g: Full development of } \\
\text { the available acreage by algal biofuels precludes development by Solar PV or Salinity Gradient Solar Ponds. Total } \\
\text { revenue estimates reflect the highest and lowest potential revenues from these three technologies ( } \$ 0.6 \text { to } 3 \text { million } \\
\text { annually). }\end{array}$} \\
\hline
\end{tabular}




\section{Recommended Next Steps}

\section{Geothermal}

Further analysis is required to refine estimates of the developable geothermal potential on the playa. The developable offshore potential is based on the percentage of playa exposed within the estimated bounds of the reservoir, but more accurate estimates can be achieved through volumetric assessment of the offshore resource. Further study of the geotechnical soil conditions of the playa, from a construction standpoint, would also be required to refine offshore cost estimates.

\section{Geothermal Fluid Mineral Recovery}

Since no geothermal recovery operations are commercially operating at the time of this report, a detailed manufacturing and supply chain study is needed to validate the likelihood that mineral recovery is a viable business opportunity for the region.

\section{Salinity-Gradient Solar Ponds}

Further analysis of the economic viability of salinity-gradient solar ponds, as well as the detailed investigation of the technical potential for synergy between this technology and algae development or desalination, will be required to determine if a commercialscale plant would be feasible in the region.

\section{Algal Biofuels}

Further study of the Salton Sea's water quality is required, but development of an algal biomass pilot plant on exposed Salton Sea playa could verify whether this technology is viable in the region. Development of an algal biomass pilot plant on exposed Salton Sea playa could verify whether this proposed renewable energy restoration mechanism is viable. NREL has discussed this proposed mechanism with two organizations currently exploring pilot studies at this location, UCSD and Synthetic Genomics, Inc., which operates an R\&D facility next to the Salton Sea.

\section{Interactive Analysis Tool}

As part of the analysis conducted above, NREL has developed an interactive, webbased mapping tool that incorporates the data used in the report's analysis. This tool is intended to enable stakeholders to visualize renewable energy development scenarios under various conditions, such as proximity to transmission, estimated playa recession, and land ownership. Due to data use restrictions, some data is not viewable at the sub-county level. If the layers under the Developable Land Substation Buffer directory do not display on the map, please zoom out until the layer becomes visible, or uncheck this layer to zoom in on other layers. This tool can be accessed at: http://maps.nrel.gov/salton-sea.

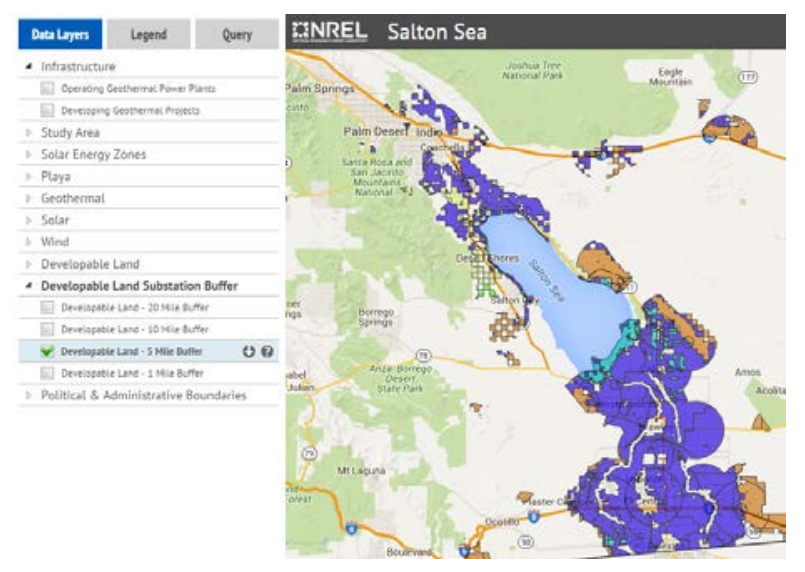

Figure ES-7: RE Development Scenario Mapping Tool Screenshot

\section{Market Competitiveness}

Due to ongoing significant changes in federal regulatory policies, increasing state RPS goals, shifts in technology costs and adoption, and accelerated plant retirements, further study of the role and value of the Salton Sea's renewable resources within regional power systems and markets is required. A variety of models and tools exist that can be utilized to assess the opportunities and challenges of developing the Salton Sea's renewable resources within the broader and rapidly changing California and Western markets. Capacity expansion models can be used to 
develop future scenarios of the market potential and transmission needs of different renewable and non-renewable options at high spatial resolution for particular focus regions, such as Southern California. Production cost models can be used to assess the operational impacts - including renewable curtailment, plant operational flexibility, transmission congestion, and changing electricity imports and exports - under future infrastructure conditions. Running these models for the Salton Sea region, with a focus on geothermal and solar, can help demonstrate the ability of regional resources to cost-effectively meet California's energy and climate objectives. Development of this analysis would help provide valuable input to ongoing planning efforts such as the DRECP and the recently announced Renewable Energy and Transmission Initiative (RETI) 2.0.

\section{Renewable Energy Policies}

Policies favorable to renewable energy could create a unique benefit to development within the region. These could include utilizing the North American Development Bank for development expertise and to leverage interest rate cost savings, streamlining permitting requirements, and providing certainty surrounding environmental permitting costs. Additional potential developments which could affect these findings include the implementation of more aggressive in-state renewable energy capacity goals, and additional project cost declines uniquely benefitting the Salton Sea region (i.e., local incentives, exceptional transmission access).

\section{Royalty Payment Structures}

Geothermal royalty structures and mineral leasing receipts are current potential sources of funding for restoration efforts. Additional potential revenues could be realized through the passage of U.S. Senate bill 1407, which would amend the revenue distribution for solar and wind energy authorizations on BLM land to include distributions to states and counties. On payments associated with renewable energy development and production, the State of California could also make efforts to pass more specific support mechanisms, such as the CA Senate Bill 1139 , which required $500 \mathrm{MW}$ of geothermal energy between 2015 and 2024. 


\section{Table of Contents}

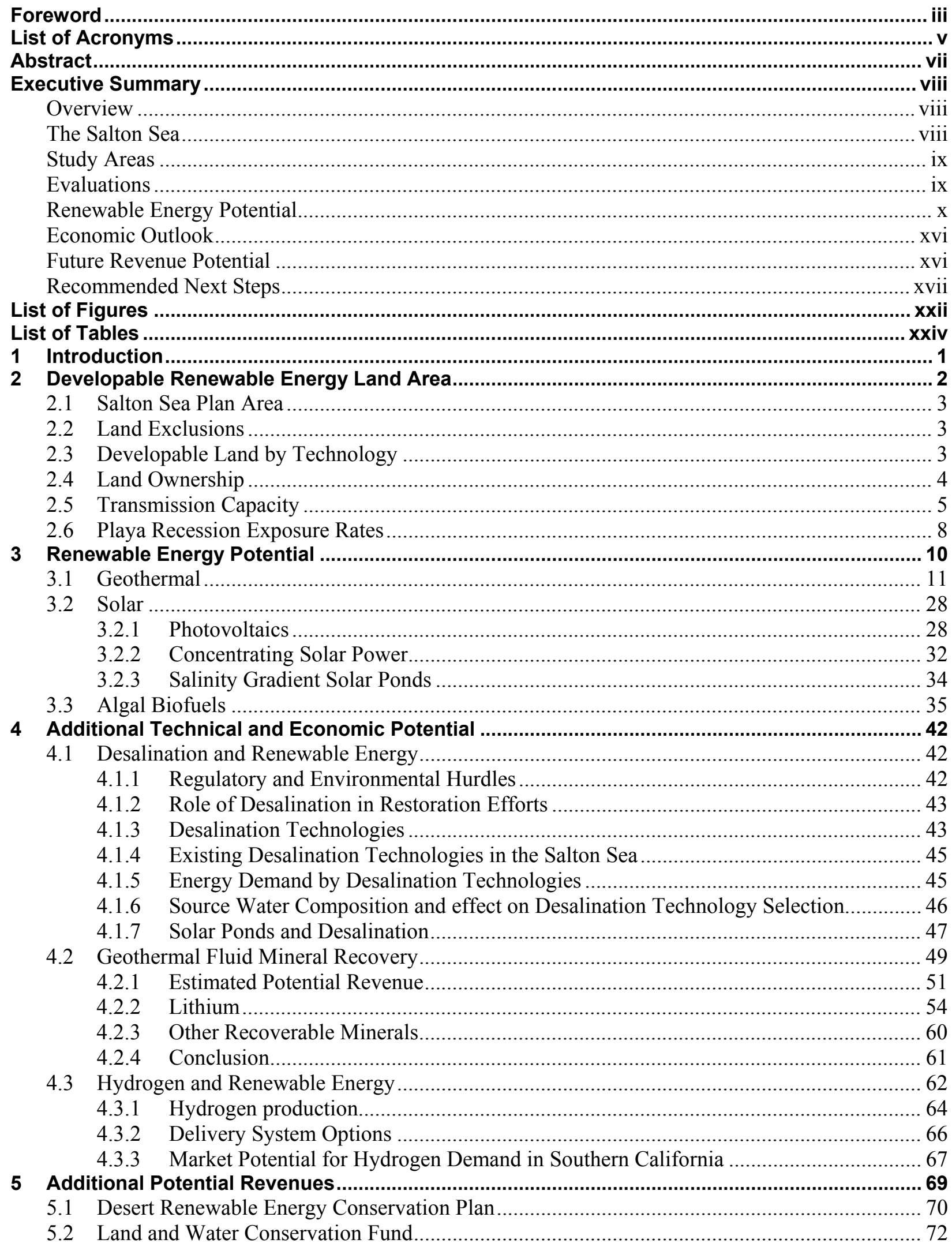


5.3 Public Lands Renewable Energy Development Act of 2015 .............................................. 73

5.4 Water Quality, Supply, and Infrastructure Improvement Act of 2014 …............................... 73

5.5 Existing and Proposed Royalty Payment Structures ................................................................ 74

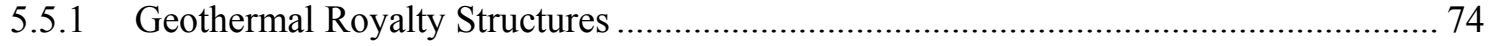

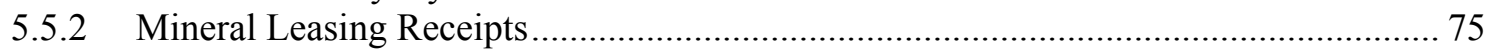

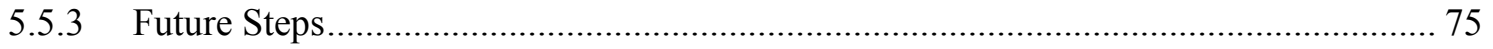

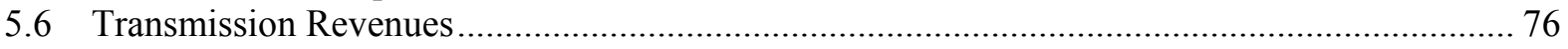

5.6.1 Transmission Capacity Build out Opportunity ……..................................................... 76

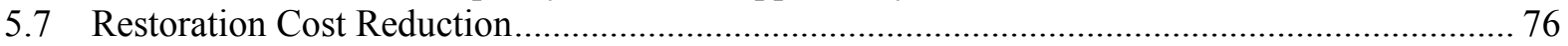

5.7.1 The North American Development Bank .................................................................. 77

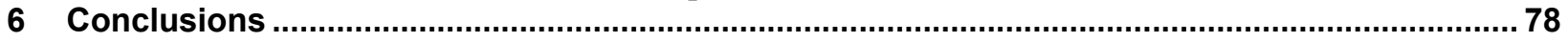

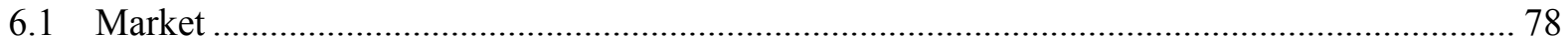

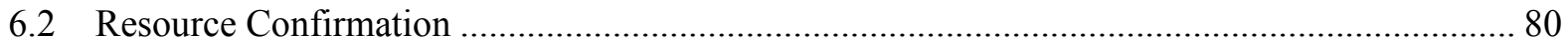

6.3 Potential Revenues from Renewable Energy Development.................................................. 81

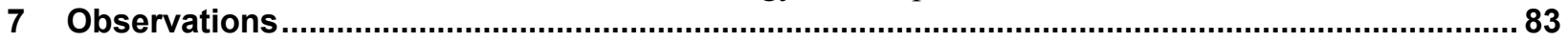

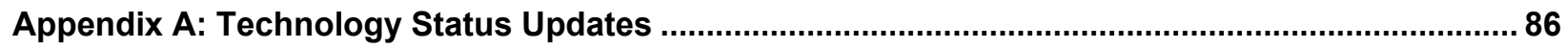

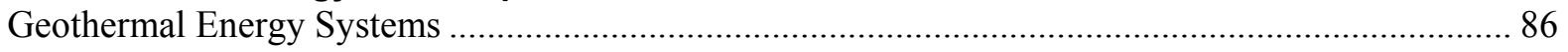

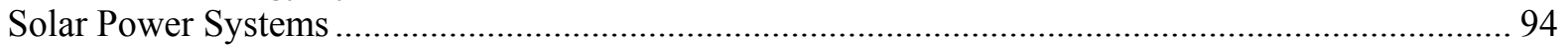

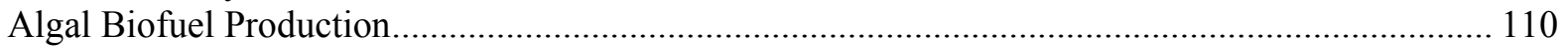

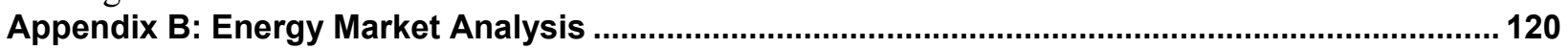

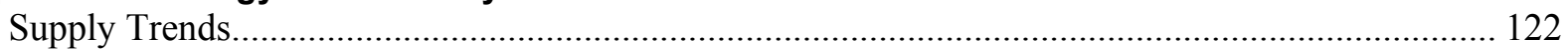

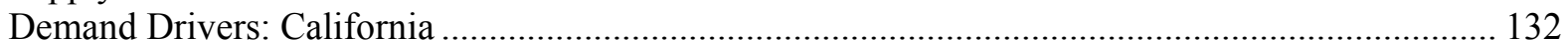

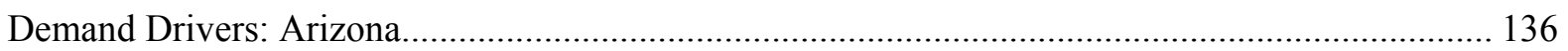

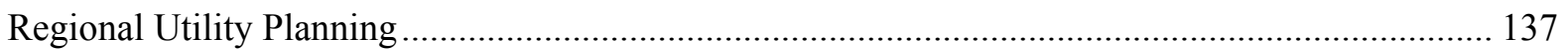

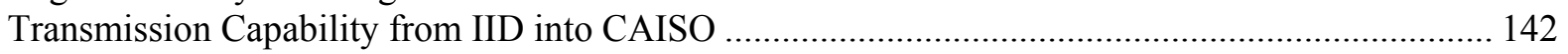

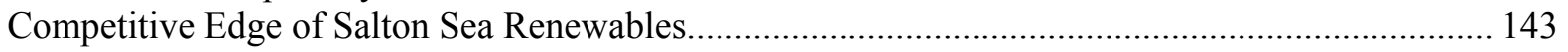

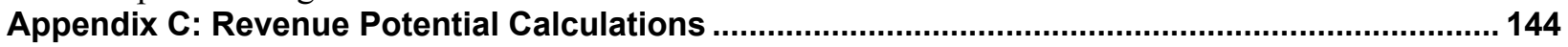

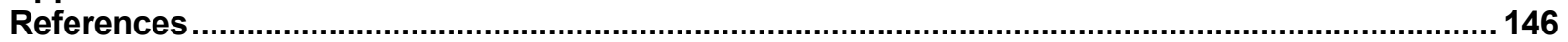




\section{List of Figures}

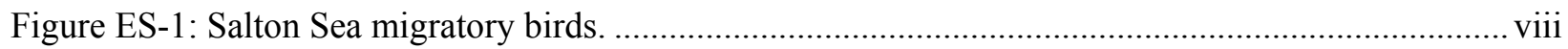

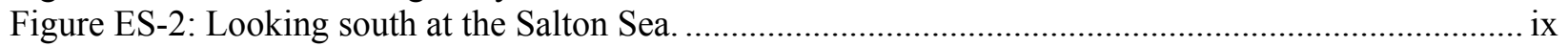

Figure ES-3: Total Developable Renewable Energy Land. ................................................................ ix

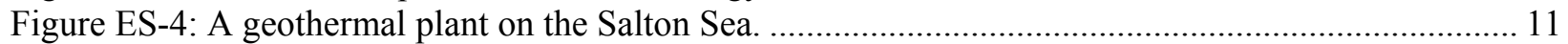

Figure ES-5: The first hydrogen fueling station, Los Angeles, CA.................................................... xiii

Figure ES-6: Algae raceway ponds; Large-scale algae biomass production ............................................

Figure ES-7: RE Development Scenario Mapping Tool Screenshot ....................................................... xvii

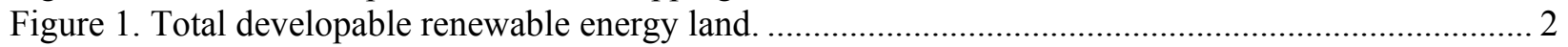

Figure 2. Total developable renewable energy land by ownership type............................................ 5

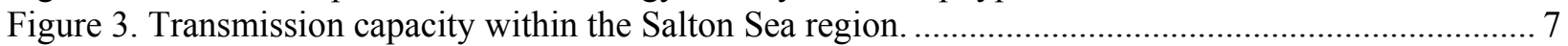

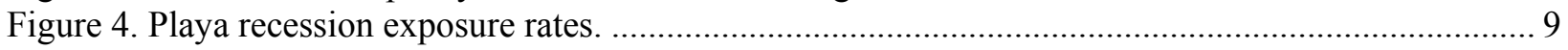

Figure 5. Schematic of a geothermal reservoir. Illustration from Geothermal Energy Association ............ 12

Figure 6. Direct-use applications versus temperature requirements. ................................................. 13

Figure 7. Total developable land for geothermal electric resource........................................................ 14

Figure 8. Location map for documented geothermal prospects in Imperial County................................. 16

Figure 9. Geothermal remote sensing prioritization matrix.................................................................... 18

Figure 10: Offshore portion of Salton Sea KGRA and recession estimate of the shoreline in 25 years..... 24

Figure 11. Potential development of offshore Salton Sea KGRA based on the shoreline recession in 25

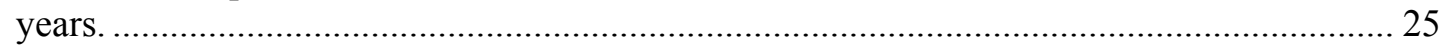

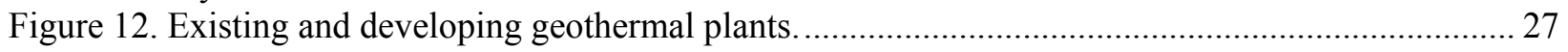

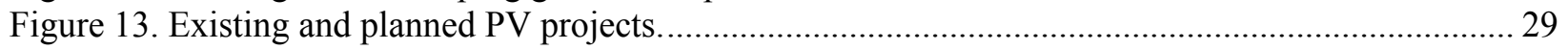

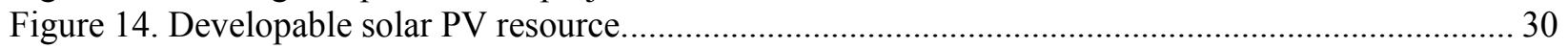

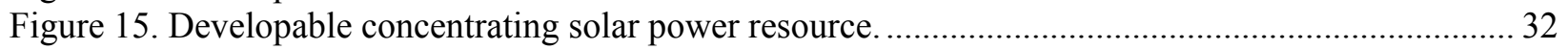

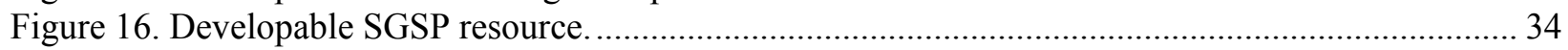

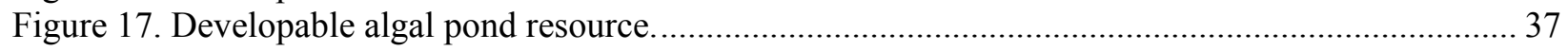

Figure 18. Desalination technology deployment worldwide. Images from Desaldata.com....................... 44

Figure 19. Thermal desalination process interfaced with a solar pond and a geothermal power plant.

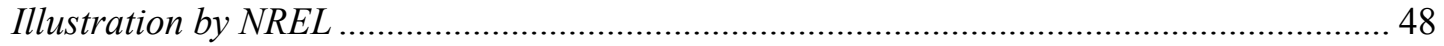

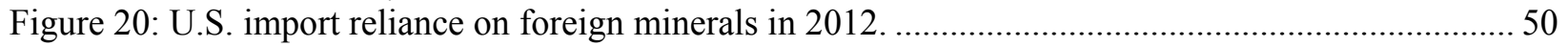

Figure 21: Strategic importance and scarcity of selected raw materials, 2011-2015 ............................ 51

Figure 22: Schematic of lithium capture from geothermal brines using a substrate ................................ 55

Figure 23: Breakdown of 2013 global lithium demand by end use products. ......................................... 58

Figure 24: Breakdown of 2012 global revenues of lithium ion batteries by application.......................... 58

Figure 25: Historic and projected global lithium consumption, by end use. .........................................5 59

Figure 26: Projected growth in global li battery demand for automotive applications..............................59

Figure 27: Regional supply chain capacity and trade flow for lithium-ion battery components............... 60

Figure 28: Process diagram for manganese and zinc removal from geothermal brines............................ 61

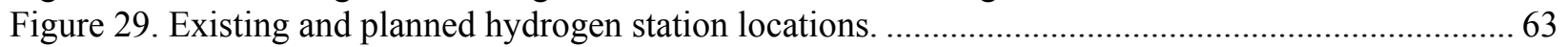

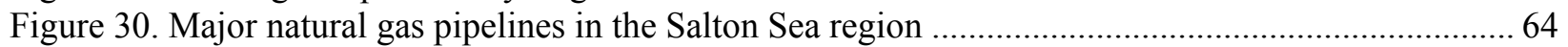

Figure 31. FCEV sales in Los Angeles and California in a hydrogen success scenario ............................. 68

Figure 32. Total FCEV sales in Los Angeles (left) and resulting hydrogen demand (right).................... 69

Figure 33. Biological resources map of the Imperial Borrego region.................................................... 72

Figure 34. Qualified NADB assistance region. Image from North American Development Bank ............ 77

Figure 35: Net cost of potential new resources included in the RPS calculator (Point estimates of the

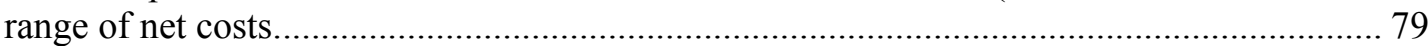

Figure 36. Potential development of offshore Salton Sea KGRA based on the shoreline recession in 25

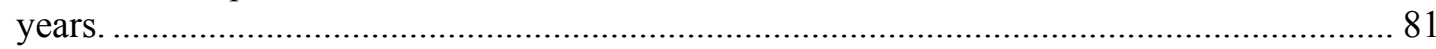

Figure A1. Schematic of a dry steam power plant. Illustration from Geothermal Energy Association ..... 86

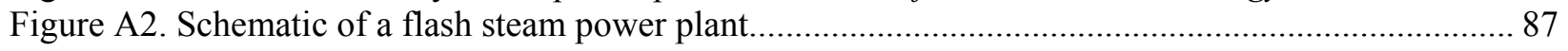




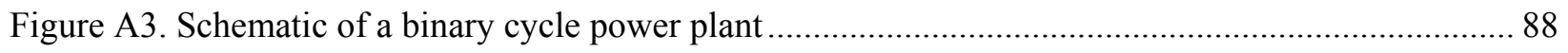

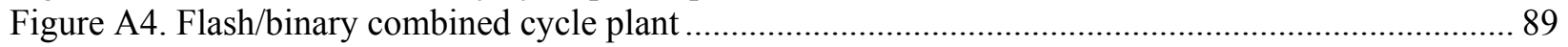

Figure A5. Typical direct-use geothermal heating system configuration. .............................................. 91

Figure A6. List of direct-use applications by temperature .................................................................. 92

Figure A7. Example of a cascading direct-use system with power production. ...................................... 93

Figure A8. Levelized power purchase agreement price for utility-scale U.S. solar projects.....................96

Figure A9. Typical PV cell construction. Illustration by NREL ......................................................... 98

Figure A10. PV cell efficiencies for various technologies under standard laboratory conditions............ 100

Figure A11. PV arrays placed in a fixed-tilt position or mounted on a tracker .................................... 100

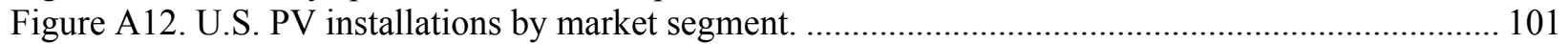

Figure A13. Parabolic trough collector and receiver tube. .............................................................. 102

Figure A14. Simplified schematic of a parabolic trough power plant. Illustration from Electric Power

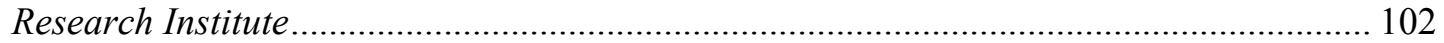

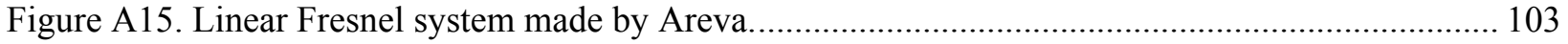

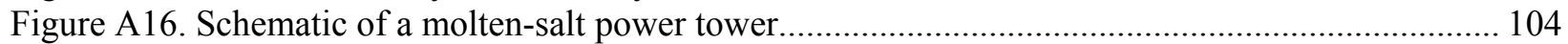

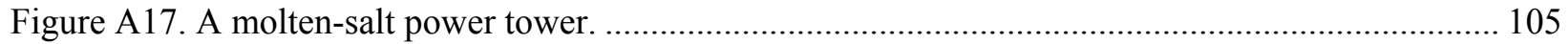

Figure A18. $25 \mathrm{~kW}$ dish/Stirling engine system made by Tessera Solar............................................. 106

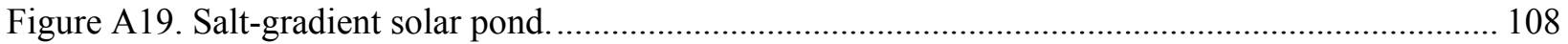

Figure A20. A solar gel pond uses a polymer gel to separate the UCZ and LCZ layers....................... 109

Figure A21. Solar pond test facility at the University of Texas E1 Paso.............................................. 110

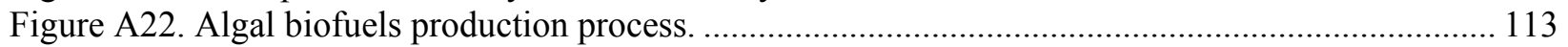

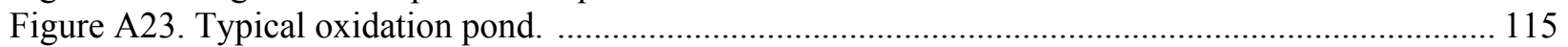

Figure A24. Spirulina production in open raceway ponds. Photo from NREL ...................................... 115

Figure A25. Samples being drawn from a tubular bag photobioreactor. ............................................ 116

Figure A26. Algal Turf Scrubber ${ }^{\circledR}$ S-154 pilot plant in Central Florida.............................................. 117

Figure B1: Imperial Irrigation District with EHV transmission paths. ............................................. 121

Figure B2: Cost benchmark based on new cycle natural gas generator........................................... 126

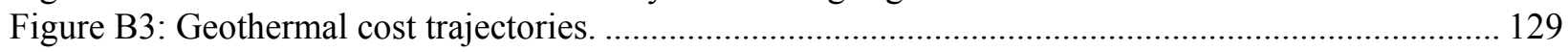

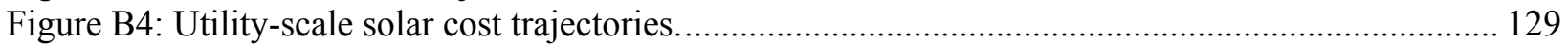

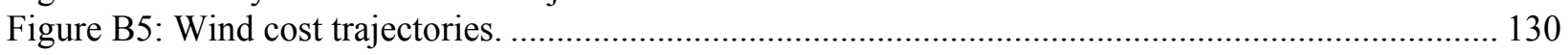

Figure B6: Net cost of potential new resources included in the RPS calculator (Point estimates of the

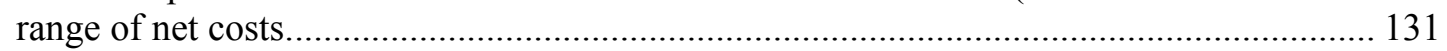

Figure B7. Regional renewable planned capacity expansion based on current IRPs............................... 138 


\section{List of Tables}

Table ES-1. Salton Sea Renewable Energy Resource Potential and Costs.............................................xii

Table ES-2. Summary of Potential Mitigation Revenues under Current Conditions ................................ Xv

Table ES-3. Summary of Potential Mitigation Revenues under Future Conditions ................................. xvi

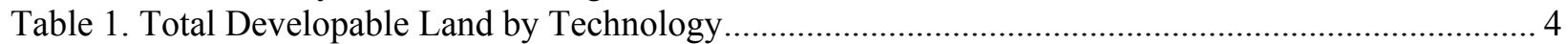

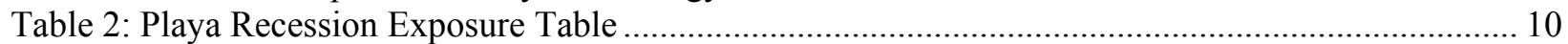

Table 3. Summary of Developable Capacity by Technology in 2030 ..................................................... 11

Table 4. Current Status of Operating Power Plants in Imperial County ............................................... 16

Table 5. Temperature and Total Dissolved Solids Content of Geothermal Areas in Imperial County...... 19

Table 6. Typical Geothermal Brine and Gas Chemistry of Imperial Valley KGRAs..............................20

Table 7. Electricity Generation Capacity Estimates for Imperial County Geothermal Areas ....................222

Table 8. Summary of Published Salton Sea Geothermal Area Resource Estimates ................................. 23

Table 9. Onshore and Offshore Portions of Salton Sea KGRA Based on Most Recent Resource Potential

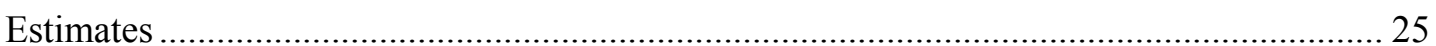

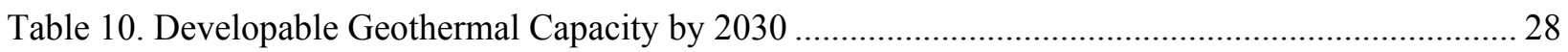

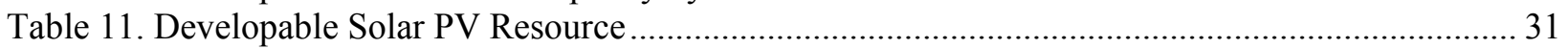

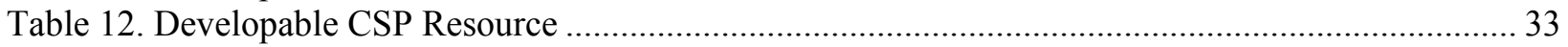

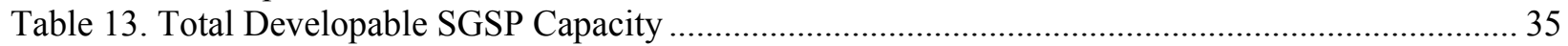

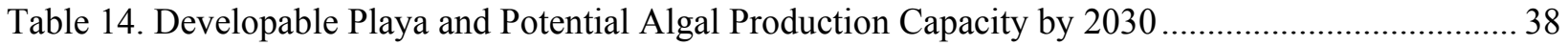

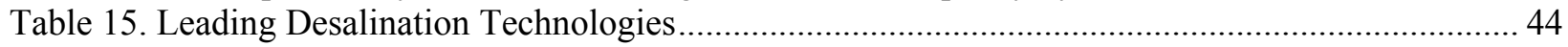

Table 16. Typical Energy Consumption by Primary Desalination Technologies.................................... 45

Table 17. Total Dissolved Solids of Potential Source Water for Desalination for the Imperial Valley ..... 47

Table 18. Use of Geothermal Energy, Solar Ponds, and Desalination.................................................... 48

Table 19. Assumptions and Estimation of Annual Royalty Revenue Derived from Lithium Mineral

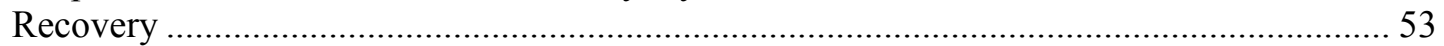

Table 20: Summary of Global Lithium Supplies (Production, Reserves, and Resources) and Sources* ... 56

Table 21. Hydrogen Technical Production Potentials and Total FCVs Supported..................................65

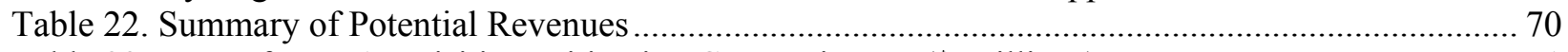

Table 23. NPV of Non-Acquisition Mitigation Cost Estimates (\$ Millions)............................................ 71

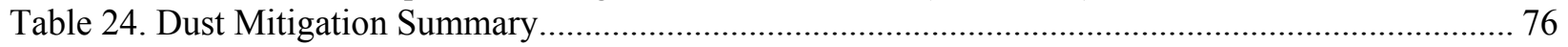

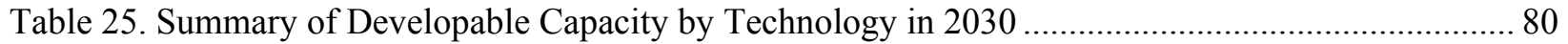

Table A1. Geothermal Project Development Cost Breakdown and Timing ............................................ 89

Table A2. Representative Current Utility-Scale Geothermal Costs (2015) ............................................ 90

Table A3. Overview of Different Solar Technologies (NREL) ......................................................... 95

Table A4. Representative Current and Future Utility-Scale Solar Costs ................................................ 96

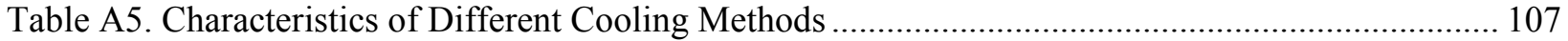

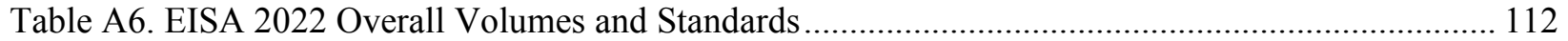

Table A7. Summary of Algae Cultivation Characteristics (NREL) ..................................................... 114

Table B1: Undeveloped Potential Resources in the RPS Calculator (GWh per year)........................... 124

Table B2. Renewable Technology Cost Assumptions (2015 dollars) .................................................. 127

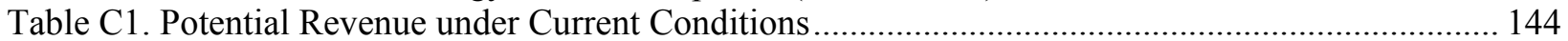

Table C2. Potential Revenue under Future Conditions....................................................................... 145 


\section{Introduction}

Outflows from the Colorado River rapidly filled the Salton basin between 1905 and 1907, giving rise to the Salton Sea, which is now the largest lake in California. The salinity of this body of water exceeds that of the Pacific Ocean and continues to increase to levels that only the tilapia fish have been able to survive. Numerous freshwater species, most notably the endangered desert pupfish, continue to live in the surrounding marshes, canals, and rivers (U.S. Fish \& Wildlife Service 2008). The Salton Sea has also become a major avian habitat, with over 400 species sighted to date. Due to continuing concerns surrounding water scarcity in the state of California, the Quantitative Settlement Agreement (QSA) was signed in 2003 and clarified in a court ruling in 2013. Water conservation measures in the agreement call for the water to be transferred from regional agricultural to urban use in San Diego and the Coachella Valley. Pursuant to this agreement, mitigation inflows to the Salton Sea will be discontinued in 2017. Also pursuant to this agreement, the state of California agreed to statutory and contractual obligations to ensure the restoration of the Salton Sea.

The Salton Sea and the surrounding region face a wide range of environmental concerns from reduced inflows and other environmental factors, including exposed, potentially emissive lakebeds; rising salinity; and impacts to aquatic and migratory avian species. A restoration program is urgently needed to address these concerns. ${ }^{1}$

After commissioning a study listing the various restoration alternatives, with estimated construction costs of between $\$ 2.3$ billion for the lowest cost alternative and $\$ 8.9$ billion for the preferred alternative, sources of funding summing to roughly $\$ 32$ million as of 2013 have been acquired thus far, with a 2013 state audit identifying the total estimated funding for Salton Sea restoration as $\$ 114$ million. $^{2}$

Through a grant from the State of California Natural Resources Agency, under Agreement No. 0540-SSA 1, the Salton Sea Authority has retained Tetra Tech to serve as the prime contractor to help complete the plan. Tetra Tech's subcontractor, the National Renewable Energy Laboratory (NREL), was retained to prepare a report analyzing the potential of various renewable energy technologies to contribute financially to Salton Sea restoration efforts. In 2013, the Imperial Irrigation District (IID) commissioned a preliminary study on the potential for renewable energy projects in the Salton Sea region to partially fund the restoration of the Salton Sea. This feasibility study examined the revenue potential from land leases in the Imperial Valley for renewable energy project, and estimated that roughly $\$ 4.1$ billion might be realizable over the study period of 2016 to 2045 . This study specifically seeks to confirm and refine these prior revenue potential estimates, provide a technical review of the renewable energy technologies under consideration, and develop estimates of the region's developable production potential through the year 2030 .

\footnotetext{
${ }^{1} I d$.

${ }^{2}$ California State Auditor. "California State Auditor Report 2013-101”. November 2013. https://www.bsa.ca.gov/pdfs/reports/2013-101.pdf. Accessed 6/2/15.
} 


\section{Developable Renewable Energy Land Area}

To identify the land available for renewable energy development in the Salton Sea study area (Figure 1), geographic information system (GIS) methods were used to compile land use shapefiles from the multiple stakeholders in the region. The Desert Renewable Energy Conservation Plan (DRECP), Imperial County, Riverside County, IID, and the U.S. Bureau of Land Management (BLM) all contributed to the final selection of developable land.

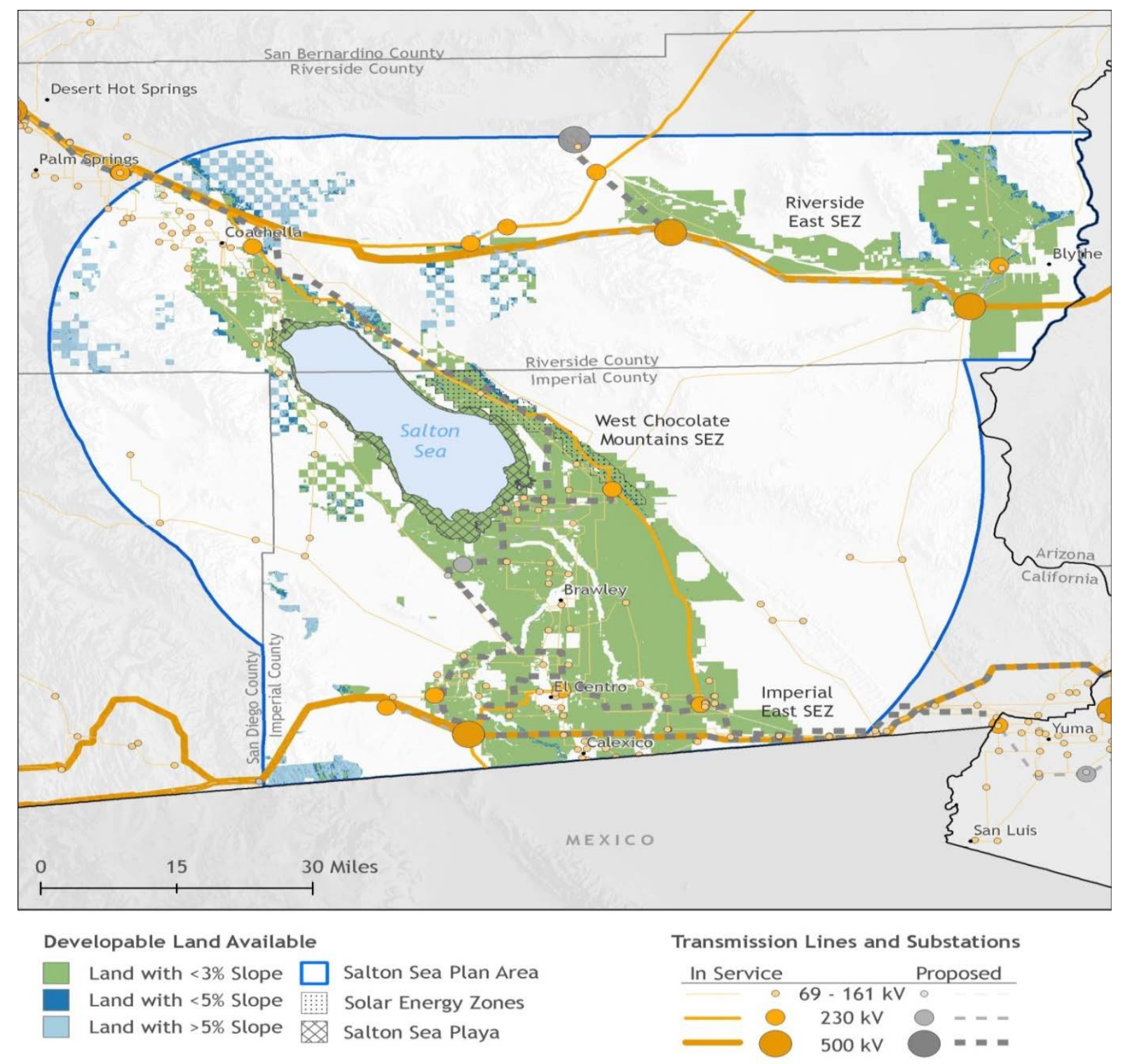

Figure 1. Total developable renewable energy land. ${ }^{3}$

\footnotetext{
${ }^{3}$ Data Sources: National Renewable Energy Laboratory; Desert Renewable Energy Conservation Plan; Riverside County, CA; Imperial County, CA; Imperial Irrigation District; BLM.
} 


\subsection{Salton Sea Plan Area}

The Salton Sea Plan area is described as follows. The national border with Mexico was established as the southern border. The northern and eastern borders were extended to the eastern extent of Riverside County in order to incorporate the Riverside East solar energy zone (SEZ). The western border was extended to roughly correspond to the DRECP Plan boundary. The Salton Sea playa was listed as a potentially developable area as well, although there is uncertainty concerning both the rate of recession and additional costs for development within this land area.

\subsection{Land Exclusions}

The first level of land exclusion applied to the Salton Sea study area was all land outside of the DRECP Preferred Alternative Plan that did not fall into one of the following designations:

- Development focus areas

- DRECP variance lands

- Future assessment areas

- Special analysis areas

- Tribal lands.

The draft DRECP is a collaborative environmental planning effort between numerous state and federal agencies to ensure efficient biological mitigation and conservation in California's desert environments. This group has already conducted a thorough research process that considered multiple interests in the region and that provided a reasonable starting point for the Salton Sea analysis. Using the draft DRECP Preferred Alternative Plan as a starting point, NREL led stakeholder meetings with representatives from Imperial County, Riverside County, IID, and BLM to refine decisions on which land types to include in the Salton Sea study area.

Following the stakeholder meetings, the second level of land exclusion focused on land-use designations provided by the counties. In this step, cities, residential areas, commercial areas, industrial areas, conservation and habitat areas, parks, and mountainous land were excluded from the study area. The final level of exclusion applied federal land considerations and excluded all military land and BLM Areas of Critical Environmental Concern. The most notable exclusion of military land was the West Chocolate Mountain Gunnery Range and other military bases within the region; due to their continued operation of training exercises in these regions, these areas are not considered to be suitable for the development of renewable energy. The remaining land comprised the final developable land dataset that represent areas suitable for renewable energy development.

\subsection{Developable Land by Technology}

The developable land was further refined for each technology considered based on the individual technology constraints. Only land with less than $5 \%$ slope was considered for solar photovoltaics (PV), land with less than 3\% slope was considered for concentrating solar power (CSP), land within previously-identified known geothermal resource areas (KGRA) was considered for geothermal, and only land on the Salton Sea playa was considered for algal biofuels and salinity 
gradient solar ponds (SGSP). Land shown as "no slope constraint" indicates that the land was developable based on land exclusions listed above but exceeded 5\% slope. The total land available for each technology is shown in Table 1. Although developable land within the KGRAs was excluded from all other technologies, it was assumed that this land would be a first priority for geothermal development, although it may be possible to intersperse these technologies alongside future geothermal plants.

Table 1. Total Developable Land by Technology

\begin{tabular}{|c|c|c|c|c|c|}
\hline Technology & $\begin{array}{l}\text { Developable land } \\
\text { (acres) }\end{array}$ & $\begin{array}{l}\text { Developable } \\
\text { Land Within } 1 \\
\text { Mile of } 138 \mathrm{kV}- \\
230 \mathrm{kV} \text { Trans. } \\
\text { Access }\end{array}$ & $\begin{array}{l}\text { Developable } \\
\text { Land Within } 1 \\
\text { Mile of } 500 \mathrm{kV} \\
\text { Trans. Access }\end{array}$ & $\begin{array}{l}\text { Developable } \\
\text { Land Within } \\
5 \text { Milles of } \\
\text { 138kV-230kV } \\
\text { Trans. } \\
\text { Access }\end{array}$ & $\begin{array}{l}\text { Developable } \\
\text { Land Within } \\
5 \text { Miles of } \\
500 k V \\
\text { Trans. } \\
\text { Access }\end{array}$ \\
\hline $\begin{array}{l}\text { Geothermal } \\
\text { (KGRA) }\end{array}$ & $\begin{array}{c}232,051(1.78 \mathrm{GW} \\
2.94 \mathrm{GW})\end{array}$ & $\begin{array}{c}1851(1.78 \mathrm{GW} \\
2.94 \mathrm{GW})^{*}\end{array}$ & 0 & 50,330 & 58 \\
\hline PV & $\begin{array}{c}815,271 \\
(103 \mathrm{GW})\end{array}$ & $\begin{array}{c}14,405 \\
(1.8 \mathrm{GW})\end{array}$ & $\begin{array}{c}56.5 \\
(.007 \mathrm{GW})\end{array}$ & $\begin{array}{c}251,853 \\
(31.9 \mathrm{GW})\end{array}$ & $\begin{array}{c}73,563 \\
(9.3 \mathrm{GW})\end{array}$ \\
\hline CSP & $\begin{array}{l}771,656 \\
(77 \mathrm{GW})\end{array}$ & $\begin{array}{l}13,147.1 \\
(1.3 \mathrm{GW})\end{array}$ & $\begin{array}{c}56.5 \\
(.006 \mathrm{GW})\end{array}$ & $\begin{array}{c}238,874 \\
(23.9 \mathrm{GW})\end{array}$ & $\begin{array}{c}72,617 \\
(7.3 \mathrm{GW})\end{array}$ \\
\hline $\begin{array}{c}\text { SGSP } \\
\text { (offshore) }\end{array}$ & $\begin{array}{c}26,628 \\
(0.444 \mathrm{GW})\end{array}$ & 0 & 0 & 9,938 & 0 \\
\hline $\begin{array}{c}\text { Algal } \\
\text { biofuels } \\
\text { (offshore) }\end{array}$ & 32,821 & 0 & 0 & 9,938 & 0 \\
\hline
\end{tabular}

*While developable land is required for development, geothermal capacity is more accurately estimated based on volumetric assessment in Section 4.1, rather than an acres/MW assumption.

Data Sources: National Renewable Energy Laboratory; Desert Renewable Energy Conservation Plan; Riverside County, CA; Imperial County, CA; Imperial Irrigation District; BLM.

\subsection{Land Ownership}

The primary land classifications within the developable area of the Salton Sea region are private lands within Imperial and Riverside Counties, followed by BLM ownership. The BLM has currently identified the Imperial East, Riverside East, and Chocolate Mountain SEZs as priority areas for utility-scale solar development. Of the total available area under BLM ownership, 203,051 acres fall within the SEZs. Development within the BLM SEZs will likely be governed by the BLM's competitive leasing program. Based on discussions with BLM, currently all solar and wind energy right-of-way revenue receipts (acreage fee and megawatt (MW) capacity fee) are allocated to the Treasury, although federal legislation could potentially change this allocation in the future. Revenues from geothermal royalty payments are currently shared with the states and counties within which a project is located. Development on Riverside or Imperial County land will likely require negotiations with the individual landowners in the development area of interest. Also of note are the 20,563 acres owned by the Torres-Martinez Desert Cahuilla Indian 
Tribe; however, renewable energy development on tribal lands is often subject to separate regulations.

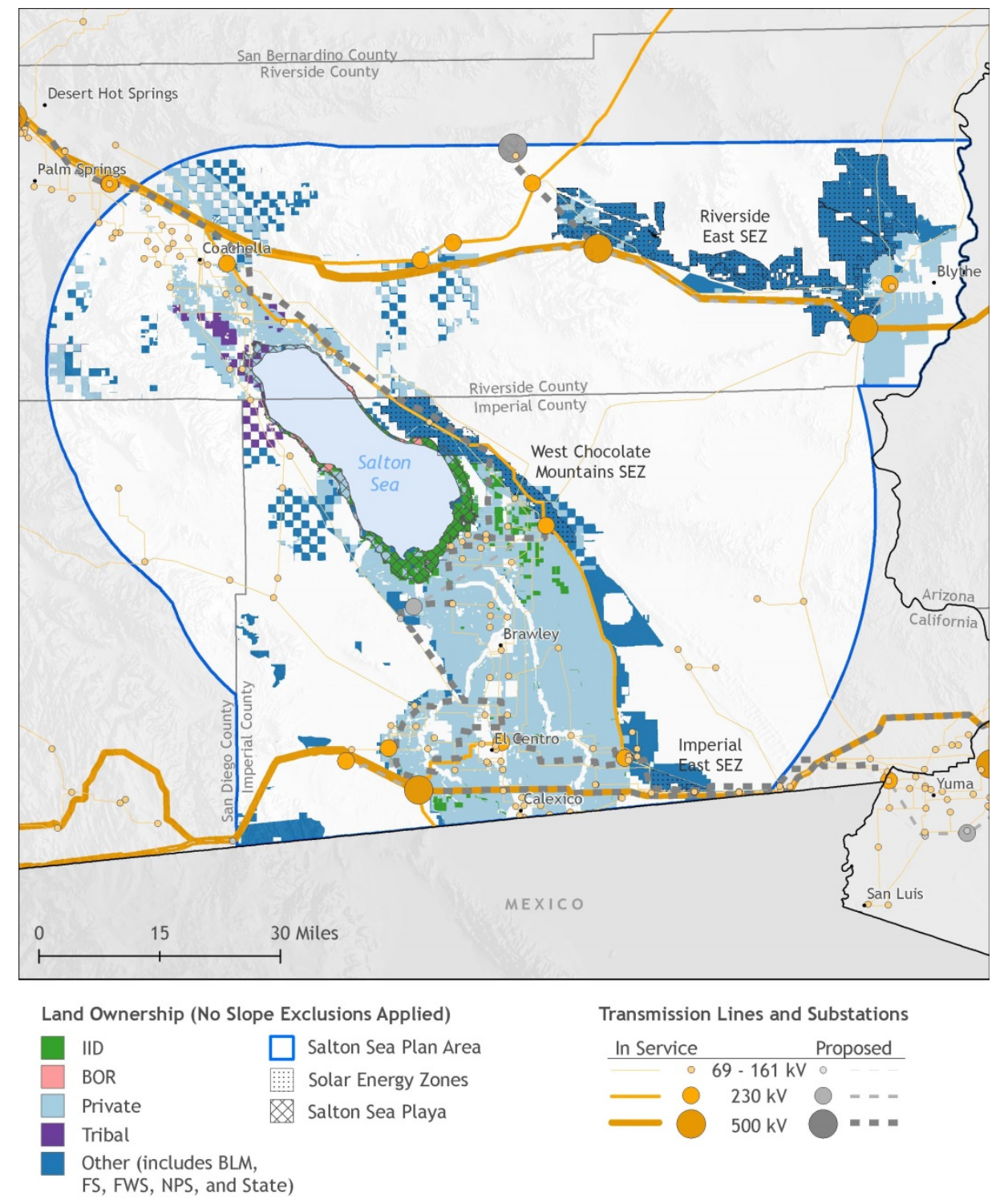

Figure 2. Total developable renewable energy land by ownership type. ${ }^{4}$

\subsection{Transmission Capacity}

As shown in Table 1, the developable land was screened to identify its proximity to electric substations in the region. The developable land was grouped into categories of $1,5,10$, and 20 miles from large substations $(500 \mathrm{kV})$ and small substations $(138 \mathrm{kV}, 161 \mathrm{kV}$, or $230 \mathrm{kV})$. A one mile radius from substations between $138 \mathrm{kV}$ and $230 \mathrm{kV}$ was selected as the most likely

\footnotetext{
${ }^{4}$ Data Sources: National Renewable Energy Laboratory; Desert Renewable Energy Conservation Plan; Riverside County, CA; Imperial County, CA; Imperial Irrigation District; BLM. Ventyx Velocity Suite 2014.
} 
developable land area for the majority of projects, with the caveat that development of transmission infrastructure could have a significant impact on the future developable area (Figure 3). Most of the transmission infrastructure in the region is developed by the utilities: IID, San Diego Gas \& Electric (SDG\&E), and Southern California Edison (SCE). The Western Area Power Administration (WAPA) also has some lines for supporting service to small public power entities. In the part of Arizona adjacent to the study area, the main utilities are Arizona Public Service (APS) and Salt River Project (SRP). However, development of transmission lines is costly, with the typical cost per mile for a $230 \mathrm{kV}$ transmission line between $\$ 940,000$ and $\$ 960,000 .^{5}$ Although the completion date for many of the proposed lines is still uncertain, the northern line (Devers-Colorado River) just went on line, and the line into Arizona (North GilaImperial Valley 2) is scheduled for completion in 2019. These subsets of developable land provide an additional tool for ranking the areas of highest potential for renewable energy development.

\footnotetext{
${ }^{5}$ https://www.wecc.biz/Reliability/2014_TEPPC_Transmission_CapCost_Report_B+V.pdf
} 


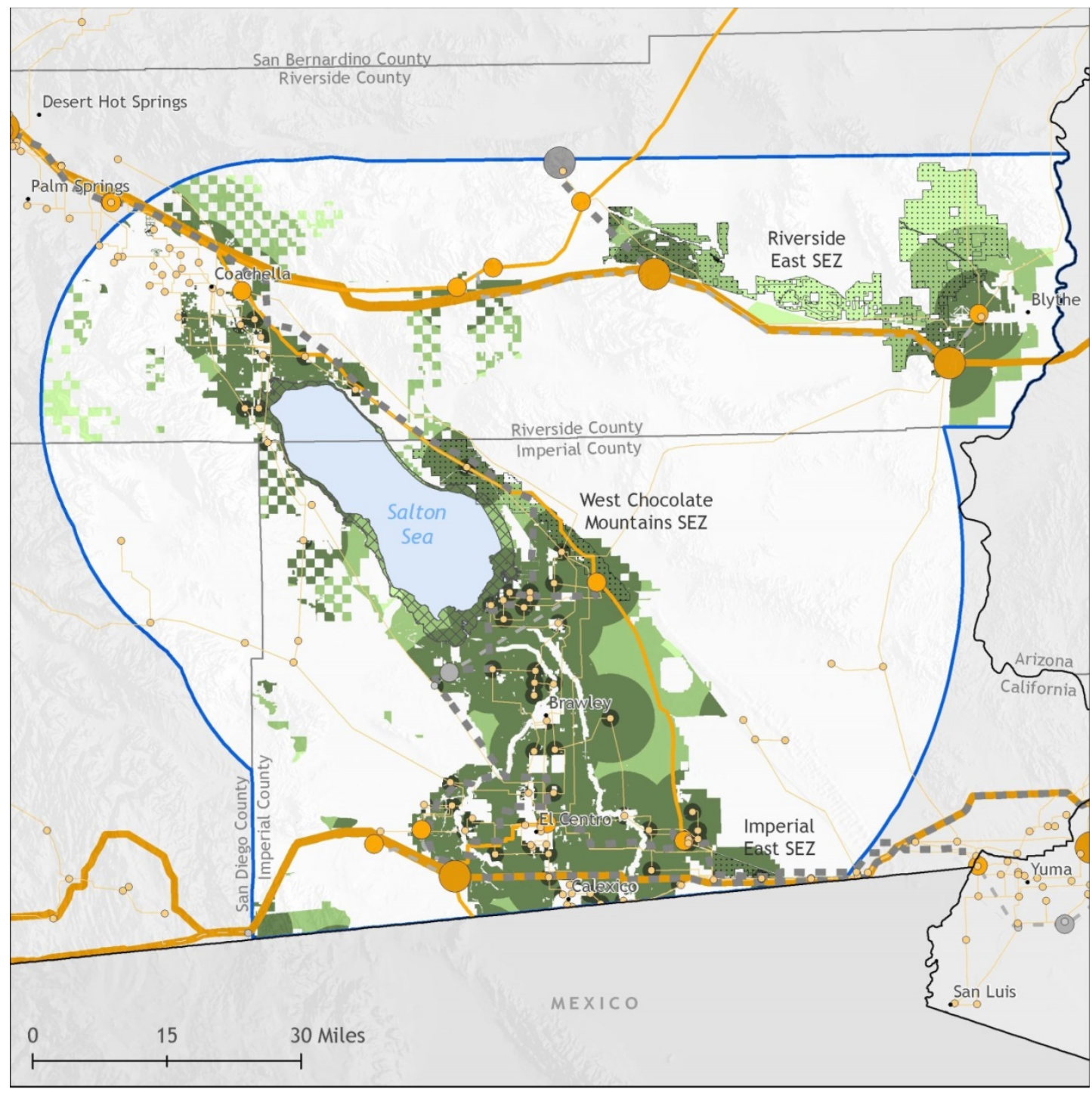

RE Developable Land Within 1 mile of 69+ kV substation Within 5 miles of 69+ kV substation Transmission Lines and Substations

$\square$ Salton Sea Plan Area
Solar Energy Zones
Salton Sea Playa

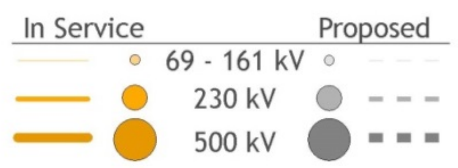

Within 10 miles of $69+\mathrm{kV}$ substation Within 20 miles of $69+\mathrm{kV}$ substation

Data Sources: National Renewable Energy Laboratory; Desert Renewable Energy Conservation Plan; Riverside County, CA; Imperial County, CA; Imperial Irrigation District; BLM; Ventyx Velocity Suite 2014

Figure 3. Transmission capacity within the Salton Sea region. 


\subsection{Playa Recession Exposure Rates}

For the purposes of this report, playa exposed by the recession of the Salton Sea shore from 2010 levels will be defined as "offshore". Figure 4 and Table 2 show the projected recession rates at the southern end of the Salton Sea. The dataset was received from Tetra Tech and reflects playa recession estimates through the study period. Although playa exposure will also occur on the north end, given the presence of the developable geothermal potential currently offshore within the Salton Sea KGRA, the southern end was examined in greater detail. Based on the modeled recession rates, the Salton Sea will recede most rapidly between 2020 and 2030, exposing roughly 30,000 acres of playa around the entire Salton Sea, of which approximately 11,000 acres will be exposed within the Salton Sea KGRA. The Salton Sea is expected to slightly reverse its recession between 2040 and 2050; this is due to the fact that as salinity levels increase, the rate of evaporation decreases, allowing the lake to become larger, albeit at a higher salinity. Given the indication that Salton Sea levels will fluctuate over the study period, it is practical to assume that exposed playa will not be immediately developable at the date of exposure. 


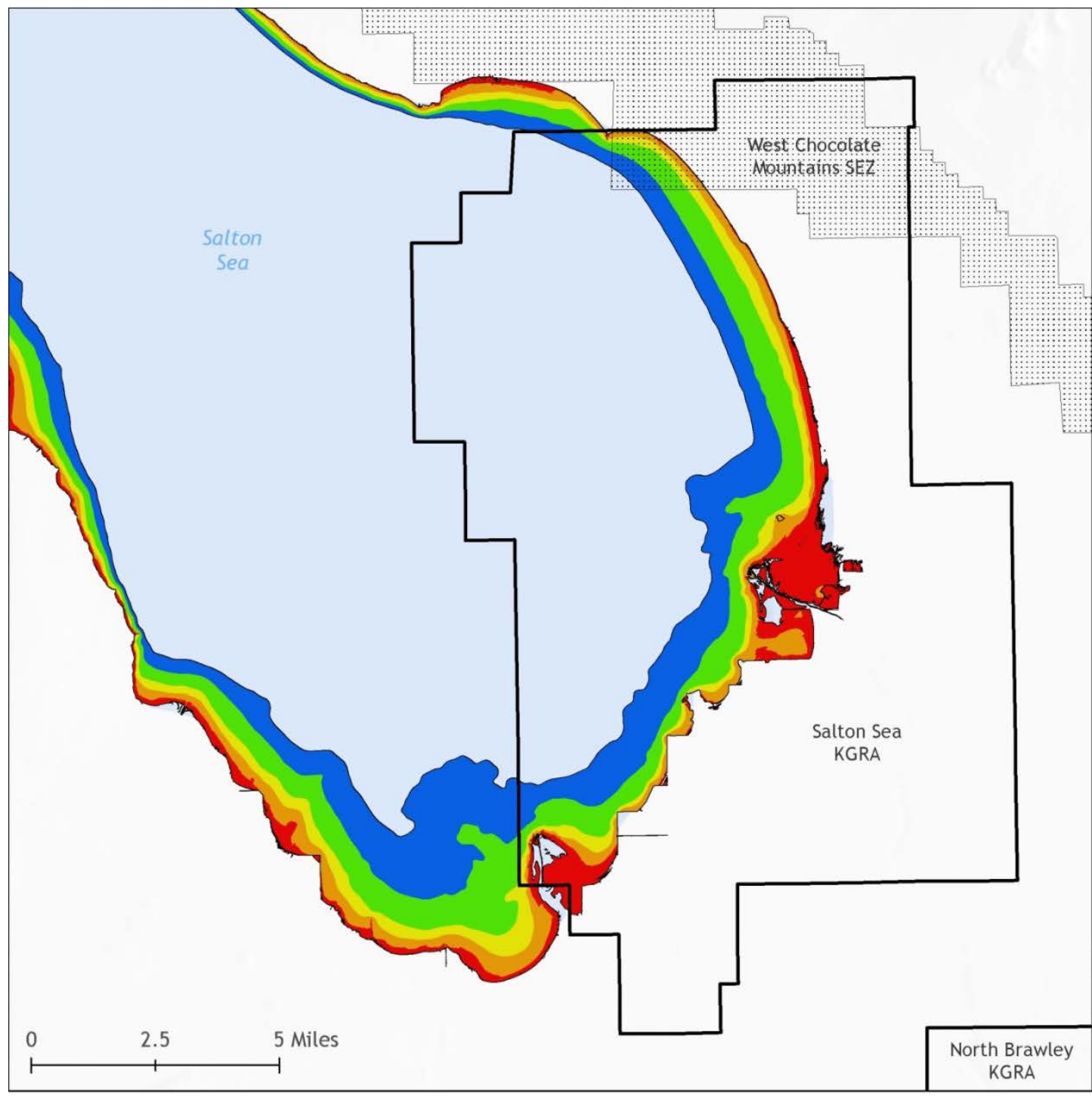

Playa Recession

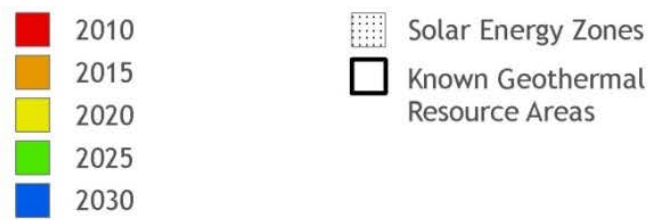

Data Sources: National Renewable Energy Laboratory; Desert Renewable Energy Conservation Plan; Tetra Tech Playa Recession Data

Figure 4. Playa recession exposure rates. 
Table 2: Playa Recession Exposure Table

\begin{tabular}{|l|c|c|c|c|}
\hline & $\begin{array}{l}\text { Area of Water - } \\
\text { total (acres) }\end{array}$ & $\begin{array}{l}\text { Area of Playa - } \\
\text { total (acres) }\end{array}$ & $\begin{array}{l}\text { Area of Water - } \\
\text { Salton Sea } \\
\text { KGRA only } \\
\text { (acres) }\end{array}$ & $\begin{array}{l}\text { Area of Playa - } \\
\text { Salton Sea } \\
\text { KGRA only } \\
\text { (acres) }\end{array}$ \\
\hline $\begin{array}{l}\text { Salton Sea: full } \\
\text { body }\end{array}$ & 233,400 & - & 52,800 & - \\
\hline Full Playa & 111,100 & 122,200 & 13,500 & 39,300 \\
\hline 2010 Recession & 226,400 & 7,000 & 49,800 & 3,100 \\
\hline 2015 Recession & 220,000 & 13,400 & 47,900 & 5,000 \\
\hline 2020 Recession & 213,400 & 20,000 & 46,000 & 6,800 \\
\hline 2025 Recession & 199,600 & 33,800 & 41,100 & 11,700 \\
\hline 2030 Recession & 182,700 & 50,700 & 34,900 & 18,000 \\
\hline 2035 Recession & 181,400 & 52,000 & 34,400 & 18,500 \\
\hline 2040 Recession & 173,900 & 59,500 & 30,900 & 22,000 \\
\hline 2045 Recession & 177,600 & 55,800 & 32,600 & 20,200 \\
\hline 2050 Recession & 175,000 & 58,300 & 31,400 & 21,500 \\
\hline
\end{tabular}

Data Source: Tetra Tech Playa Recession Data

\section{Renewable Energy Potential}

Of the commercially available renewable energy technologies, geothermal, solar PV, and CSP have the most significant technical potential for development. All of these resources have large total resource potential, but constraints such as proximity to transmission access and regional cost-competitiveness of the power generated, limit the technical potential. Solar PV and CSP require between 5 and 10 acres/MW alternating current (AC), so larger scale projects could be limited by non-contiguous land parcels as well. Development on the playa will be constrained by recession rates and although playa may be exposed in a given year, there will likely be an additional lag in development due to variability in Salton Sea water levels and potentially muddy site conditions.

Within the Salton Sea study area, the southern half of the Salton Sea (both onshore and offshore) has been identified as the primary area of opportunity for significant development, primarily due to the presence of large tracts of potentially developable farm land, existing and planned projects, and greater opportunity for future transmission export capacity due to existing infrastructure. This does not preclude development in other areas; however, potentially developable solar resources exist within the West Chocolate Mountains SEZ as well. 
Table 3. Summary of Developable Capacity by Technology in 2030

\begin{tabular}{|c|c|c|c|}
\hline Technology & $\begin{array}{l}\text { Total Potential } \\
\text { (GW unless } \\
\text { otherwise } \\
\text { specified) }\end{array}$ & $\begin{array}{l}\text { Generation } \\
\text { Potential } \\
\text { (GWh/yr) }\end{array}$ & $\begin{array}{l}\text { Existing } \\
\text { Capacity } \\
\text { (GW unless } \\
\text { otherwise } \\
\text { specified) }\end{array}$ \\
\hline $\begin{array}{l}\text { Geothermal } \\
\text { (onshore) }\end{array}$ & $0.68-1.24$ & $4,765-8,690$ & 0.6 \\
\hline $\begin{array}{l}\text { Geothermal } \\
\text { (offshore) }\end{array}$ & $0.37-0.57$ & $2,593-3,995$ & 0 \\
\hline Solar PV & 1.8 & 3,672 & 5.87 \\
\hline CSP & 1.3 & 4,732 & 0.25 \\
\hline SGSP & 0.1 & 788 & 0 \\
\hline $\begin{array}{l}\text { Brine Mineral } \\
\text { Recovery }\end{array}$ & $\begin{array}{l}\text { 54,000 MT Li } \\
122,000 \mathrm{MT} \text { Li }\end{array}$ & N/A & 0 \\
\hline $\begin{array}{l}\text { Algal Biofuels } \\
\text { (offshore) }\end{array}$ & $\begin{array}{c}39,385,674 \text { gal/ } \\
\text { year }\end{array}$ & N/A & 0 \\
\hline $\begin{array}{l}\text { Algal Food } \\
\text { and Feed } \\
\text { (offshore) }\end{array}$ & $\begin{array}{l}600,000 \\
\text { tons/year }\end{array}$ & N/A & 0 \\
\hline
\end{tabular}

*Data Sources: See Tables 10-14 and Table 19 of this report.

The development of a project may reduce the technical potential ${ }^{6}$ of another resource by removing land available for development. For example, if there are both solar PV and CSP potentials for a parcel of land and a solar PV project is developed on that parcel, the technical potential for CSP will decrease because the land is no longer available. That is, the capacity potentials listed in Table 3 are independent, may refer to the same land area, and are not additive.

\subsection{Geothermal}

Geothermal energy is heat from the Earth. It is a clean, renewable resource that provides energy for a variety of applications, including power generation and commercial, industrial, and residential direct heating. It is considered a renewable resource because the heat emanating from the interior of the Earth is inexhaustible in human time scales. Geothermal energy is available everywhere; however, accessing the resource can be difficult and expensive due to physical requirements that constrain the ability to achieve a viable system. Geothermal energy systems are comprised of two primary components: subsurface and surface systems.

The subsurface system is called the geothermal reservoir (Figure 5) (Geothermal 2005). In order for a reservoir to be viable for geothermal energy utilization, there must be adequate heat, permeability, and fluid present. A geothermal reservoir is formed by a confluence of geologic processes that 1) create permeability in a rock formation and 2) deliver heat and fluid to the permeable rock unit. Depending on the heat source and local geologic constraints, the

\footnotetext{
${ }^{6}$ Technical potential refers to the renewable resource that it is technically possible to use. It does not incorporate economic factors which impact the cost to harvest the resource, or other factors such as transmission availability.
} 
geothermal fluid can be in the form of hot water or steam. This hot water/steam can then be tapped by drilling wells. The wells permit the geothermal fluid to flow (or be pumped) from the reservoir to the surface so that it can be utilized for the desired end use application. In locations where no hydrothermal reservoir exists, it is possible to drill wells that inject fluid into areas of hot dry rock as much as three miles below the Earth's surface to create an artificial geothermal reservoir. However, the Salton Sea area has plentiful high-temperature hydrothermal resources and "enhanced geothermal systems" are not needed, therefore, they are not addressed in this report.

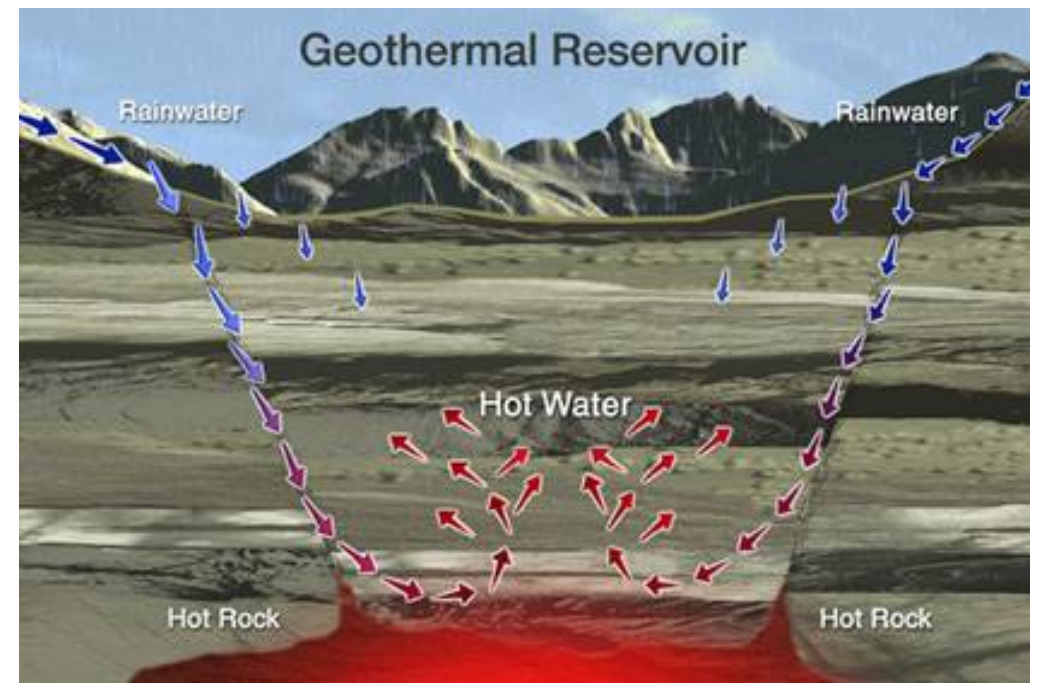

Figure 5. Schematic of a geothermal reservoir. Illustration from Geothermal Energy Association

Geothermal electricity generation passes the fluid (steam or brine) through a turbine that is connected to a generator. The primary determinants of the type (flash or binary) and capacity (MW) of a plant are the temperature of the geothermal resource and the sustainable flow rate of the geothermal fluid.

Flash steam plants utilize steam from the geothermal brine, and re-inject any leftover water. Binary cycle power plants do not flash the geothermal brine, instead the brine is used to flash a working/secondary (i.e., binary) fluid with a much lower boiling point

In general, a higher temperature and/or flow rate will equate to more power generation. For the Imperial Valley, the minimum temperature of the geothermal resource is typically $300^{\circ} \mathrm{F}$ with flow rates in excess of 1,000 gallons per minute (gpm) per well.

Geothermal fluids can be used without involving a power plant for a variety of direct-use applications such as: space heating and cooling, food preparation, hot spring bathing and spas (balneology), agriculture, aquaculture, greenhouses, and industrial processes. Required resource temperatures can be much lower for direct-use applications depending on the desired end use (Figure 6) (Geothermal 2005). Viable flow rates can be in the 100s of gpm per well range.

Geothermal energy could provide very high temperature heat for desalination, electric generation, and some industrial uses, as well as possible low-grade heat or brine for algae ponds. 


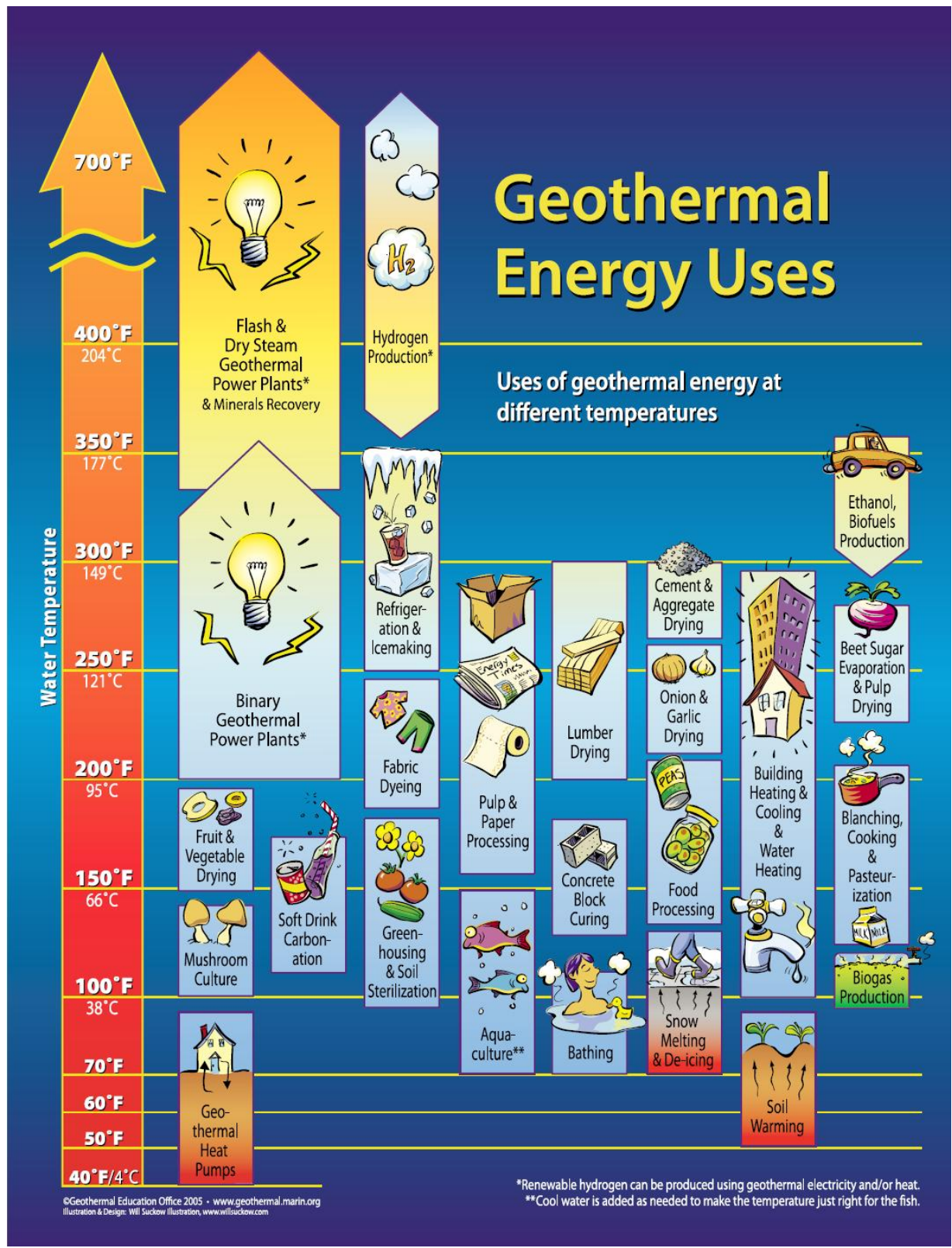

Source: GEO 2005

Figure 6. Direct-use applications versus temperature requirements. 


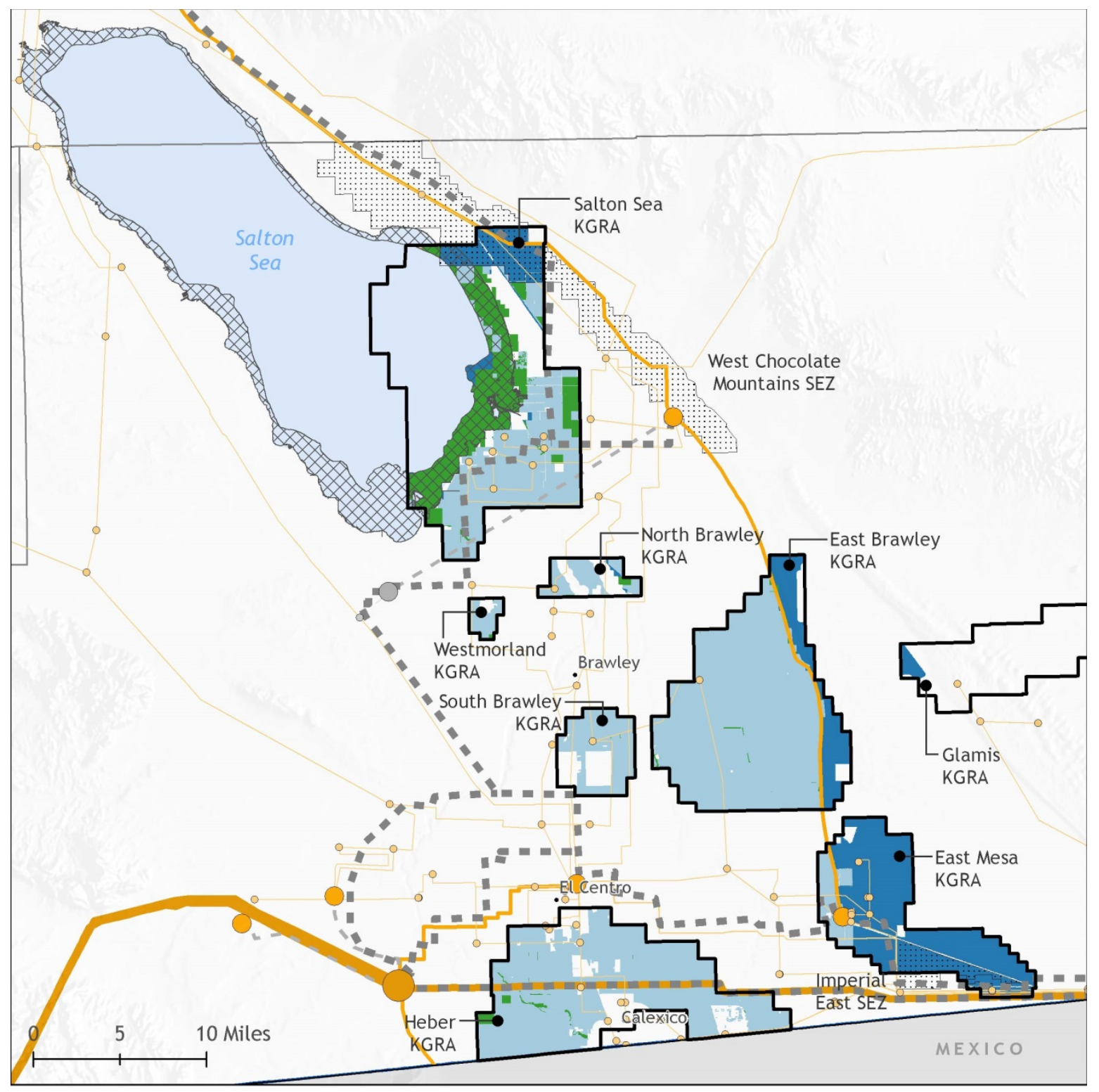

Geothermal (No Slope Exclusions Applied)

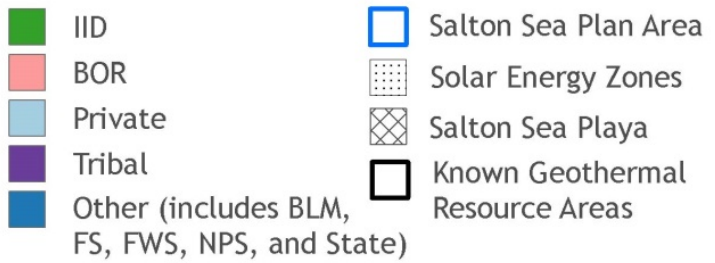

Transmission Lines and Substations

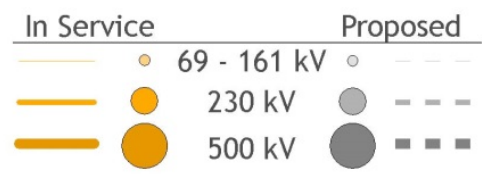

Data Sources: National Renewable Energy Laboratory; Desert Renewable Energy Conservation Plan; Riverside County, CA; Imperial County, CA; Imperial Irrigation District; BLM; Ventyx Velocity Suite 2014

Figure 7. Total developable land for geothermal electric resource.

Total developable land within the Salton Sea region KGRA as presented in Table 1 are estimates based solely on land area and exclude important criteria for more accurate geothermal capacity 
estimation, such as reservoir temperature and volume. There are roughly 233,000 acres ${ }^{7}$ of developable land within the various Imperial County KGRAs, of which 1,851 acres lie within 1 mile of a $138 \mathrm{kV}$ to $230 \mathrm{kV}$ substation. However, 50,329 acres lie within 5 miles of a $138 \mathrm{kV}$ to $230 \mathrm{kV}$ substation, which could allow for future transmission development. Additionally, geothermal power plants have small footprints; that is, they require little land compared to coal and nuclear power plants. An entire geothermal field uses 1-8 acres per MW. ${ }^{8}$ Given this relatively low land use, development of solar photovoltaics on KGRA land within the playa may also be potentially feasible after development of the geothermal resource in the area has occurred. An additional potential benefit of this geothermal development is that infrastructure such as roads and berms will be created, which can then be utilized by other projects.

The technical potential for geothermal development can be constrained by both the availability of surface land area, as well as the underlying geothermal resource. For the purposes of this analysis, the surface area was assumed to be available, and the technical potential was primarily determined by volumetric resource estimates of the underlying geothermal reservoir. A more detailed analysis of the range of likely developable geothermal potential is discussed further.

\section{Geothermal Resource Potential of Imperial County}

The Imperial Valley is geologically located in the Salton Trough, where the North American Plate and Pacific Plate are moving past each other. This plate movement causes basins to pull apart, allowing magma to rise closer to the surface, and resulting in a large geothermal anomaly. The San Andreas Fault terminates near the south end of the Salton Sea, with its fault surfaces perpendicular to the pull-apart basin. These faults constitute a permeable medium for up flow and out flow of heat flux and circulation of hydrothermal fluids.

One of the largest geothermal anomalies in the United States is located at the south end of the Salton Sea. There are thirteen documented geothermal prospects in Imperial County:

- Salton Sea

- Niland

- Westmorland

- Glamis

- East Mesa

- Heber

- Dunes

- Superstition Mountain

- North Brawley

- East Brawley

- South Brawley (Mesquite)

- Mount Signal

- Truckhaven

\footnotetext{
${ }^{7}$ There are 379,787 acres within the KGRAs, of which 232,051 acres are developable.

${ }^{8}$ EERE Geothermal Technologies Program, http://energy.gov/eere/geothermal/geothermal-power-plants-minimizing-land-use-and-impact. Accessed 8/24/2015.
} 
Nine of the thirteen geothermal prospects have been classified as KGRAs, designated by the United States Geological Survey (USGS) as having potential for beneficial exploitation of the geothermal resource suspected to exist in the area. Only four of these prospects currently have operating geothermal plants: East Mesa, Heber, North Brawley, and Salton Sea.

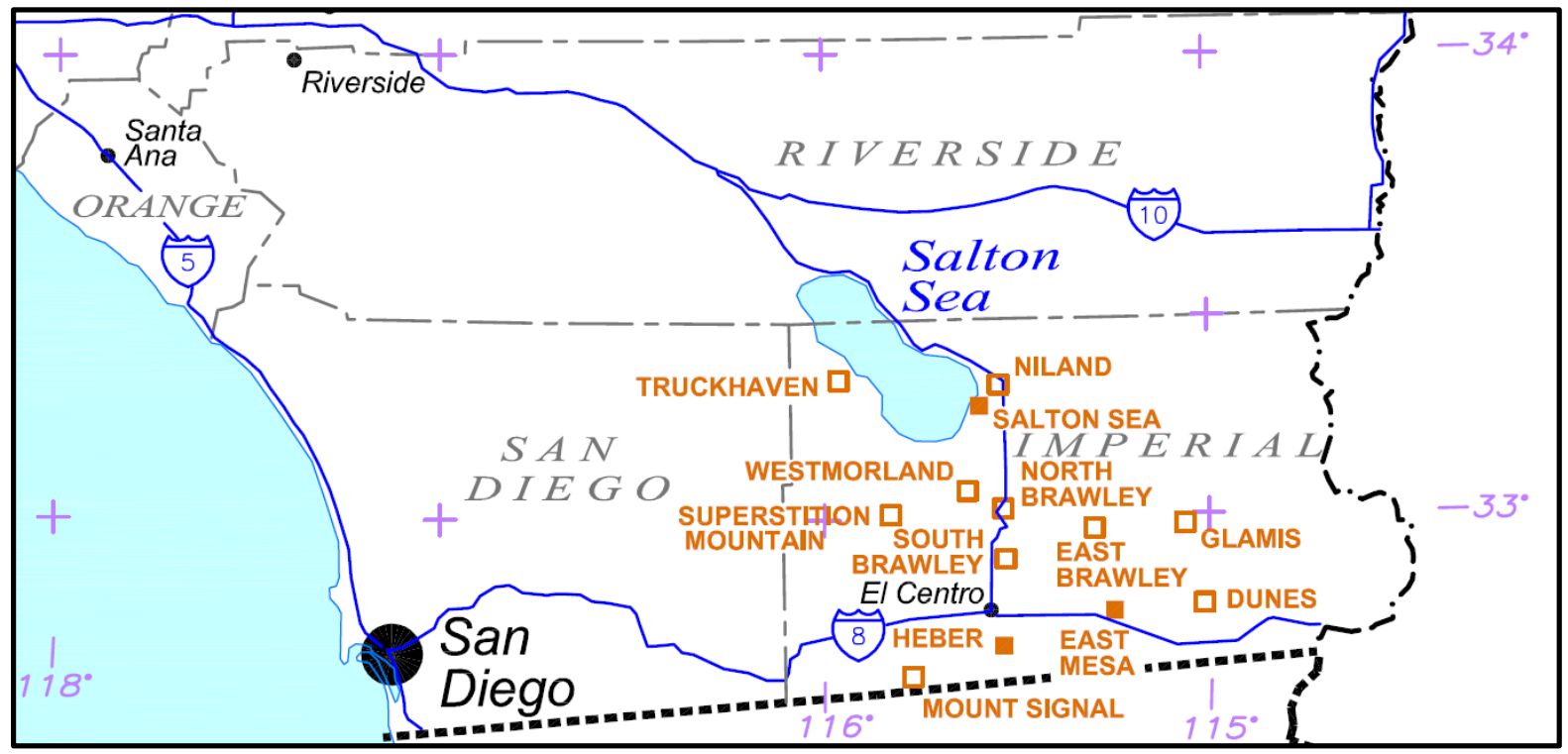

Source: GeothermEx 2004, modified by NREL

Figure 8. Location map for documented geothermal prospects in Imperial County.

Based on data from the GEA, the current nameplate geothermal capacity in Imperial County is 715.2 MW, but the operational capacity is only 602.1 MW (Table 4). The nameplate capacity of a geothermal power plant is determined by the generator's manufacturer and indicates the maximum output a generator can produce without exceeding design thermal limits. The Salton Sea area has the majority of the nameplate (installed) capacity, with $402.2 \mathrm{MW}$ in Imperial County.

Table 4. Current Status of Operating Power Plants in Imperial County

\begin{tabular}{|c|c|c|c|c|c|}
\hline $\begin{array}{l}\text { Geothermal } \\
\text { Areas }\end{array}$ & $\begin{array}{l}\text { Power Plant } \\
\text { Name }\end{array}$ & Operator & Type & $\begin{array}{l}\text { Nameplate } \\
\text { Capacity } \\
\text { (MW) }\end{array}$ & $\begin{array}{l}\text { Operational } \\
\text { Capacity } \\
\text { (MW) }\end{array}$ \\
\hline \multirow[t]{9}{*}{ East Mesa } & Ormesa I & Ormat & Binary & 26.2 & 18.4 \\
\hline & Ormesa IE & Ormat & Binary & 5 & 5 \\
\hline & Ormesa II & Ormat & Double Flash & 24 & 18 \\
\hline & Ormesa IH & Ormat & Binary & 8.8 & 6 \\
\hline & $\begin{array}{l}\text { Ormesa II } \\
\text { Upgrade }\end{array}$ & Ormat & Binary & 4.3 & 4.3 \\
\hline & GEM II & Ormat & Double Flash & 21.6 & 9 \\
\hline & GEM III & Ormat & Double Flash & 21.6 & 12 \\
\hline & $\begin{array}{l}\text { GEM Bottoming } \\
\text { Unit }\end{array}$ & Ormat & Binary & 9 & 7.4 \\
\hline & \multicolumn{3}{|l|}{ Total } & 120.5 & 80.1 \\
\hline
\end{tabular}




\begin{tabular}{|c|c|c|c|c|c|}
\hline $\begin{array}{l}\text { Geothermal } \\
\text { Areas }\end{array}$ & $\begin{array}{l}\text { Power Plant } \\
\text { Name }\end{array}$ & Operator & Туре & $\begin{array}{l}\text { Nameplate } \\
\text { Capacity } \\
\text { (MW) }\end{array}$ & $\begin{array}{l}\text { Operational } \\
\text { Capacity } \\
\text { (MW) }\end{array}$ \\
\hline \multirow[t]{6}{*}{ Heber } & Heber I & Ormat & Double Flash & 52 & 37 \\
\hline & Heber II (SIGC) & Ormat & Binary & 48 & 42 \\
\hline & Goulds II & Ormat & Binary & 16 & 13.3 \\
\hline & Goulds I & Ormat & Binary & 10.5 & 10 \\
\hline & Heber South & Ormat & Binary & 16 & 13.3 \\
\hline & \multicolumn{3}{|l|}{ Total } & 142.5 & 115.6 \\
\hline \multirow{2}{*}{$\begin{array}{c}\text { North } \\
\text { Brawley }\end{array}$} & North Brawley & Ormat & Binary & 50 & 27 \\
\hline & \multicolumn{3}{|l|}{ Total } & 50 & 27 \\
\hline \multirow[t]{12}{*}{ Salton Sea } & Salton Sea I & $\begin{array}{l}\text { CalEnergy } \\
\text { Generation }\end{array}$ & Single Flash & 10 & 9 \\
\hline & Vulcan & $\begin{array}{l}\text { CalEnergy } \\
\text { Generation }\end{array}$ & Double Flash & 40 & 40 \\
\hline & Salton Sea III & $\begin{array}{l}\text { CalEnergy } \\
\text { Generation }\end{array}$ & Double Flash & 54 & 49 \\
\hline & Salton Sea II & $\begin{array}{l}\text { CalEnergy } \\
\text { Generation }\end{array}$ & Double Flash & 20 & 17 \\
\hline & Salton Sea IV & $\begin{array}{l}\text { CalEnergy } \\
\text { Generation }\end{array}$ & Double Flash & 51 & 43 \\
\hline & Salton Sea V & $\begin{array}{l}\text { CalEnergy } \\
\text { Generation }\end{array}$ & Double Flash & 58.3 & 54 \\
\hline & Del Ranch (Hoch) & $\begin{array}{l}\text { CalEnergy } \\
\text { Generation }\end{array}$ & Double Flash & 35.8 & 35.8 \\
\hline & Elmore & $\begin{array}{l}\text { CalEnergy } \\
\text { Generation }\end{array}$ & Double Flash & 35.8 & 35.8 \\
\hline & Leather & $\begin{array}{l}\text { CalEnergy } \\
\text { Generation }\end{array}$ & Double Flash & 35.8 & 35.8 \\
\hline & CE Turbo & $\begin{array}{l}\text { CalEnergy } \\
\text { Generation }\end{array}$ & Single Flash & 11.5 & 10 \\
\hline & Hudson Ranch 1 & Energy Source & Triple Flash & 50 & 50 \\
\hline & \multicolumn{3}{|l|}{ Total } & 402.2 & 379.4 \\
\hline $\begin{array}{l}\text { Imperial } \\
\text { County }\end{array}$ & \multicolumn{3}{|l|}{ Total Capacity } & 715.2 & 602.1 \\
\hline
\end{tabular}

Source: GEA 2015

\section{Geothermal Resource Assessment}

In support of IID, a separate geothermal resource assessment study was conducted by using remote sensing techniques (Jones et al. 2011). The aim of the study was to detect the surficial evidences of deeper thermal activity. The investigators used airborne hyperspectral imagery from the Spatially Enhanced Broadband Array Spectrograph System (SEBASS) and satellite-based Advanced Spaceborne Thermal Emission and Reflection Radiometer (ASTER) imagery. 
Remote sensing data is calibrated with pre-existing surface and subsurface data sets such as:

- Presence in a KGRA: geology, stratigraphy, hydrogeology

- Geophysical data: bouguer gravity mapping, magnetotelluric (MT) resistivity surveys, and seismic refraction studies

- Heat flow mapping and temperature gradients.

The result of this study was a weighted prioritization matrix for geothermal resource potential of the area (Figure 9). Each township, measuring six miles by six miles, was divided into 36 cells of approximately one square mile each based on the abundance and quality of data. After evaluating the available data, a decision matrix was used to score areas between 2 and 31, with those cells scoring 19 or higher determined to have the greatest geothermal potential (Figure 9) (Jones et al. 2011).
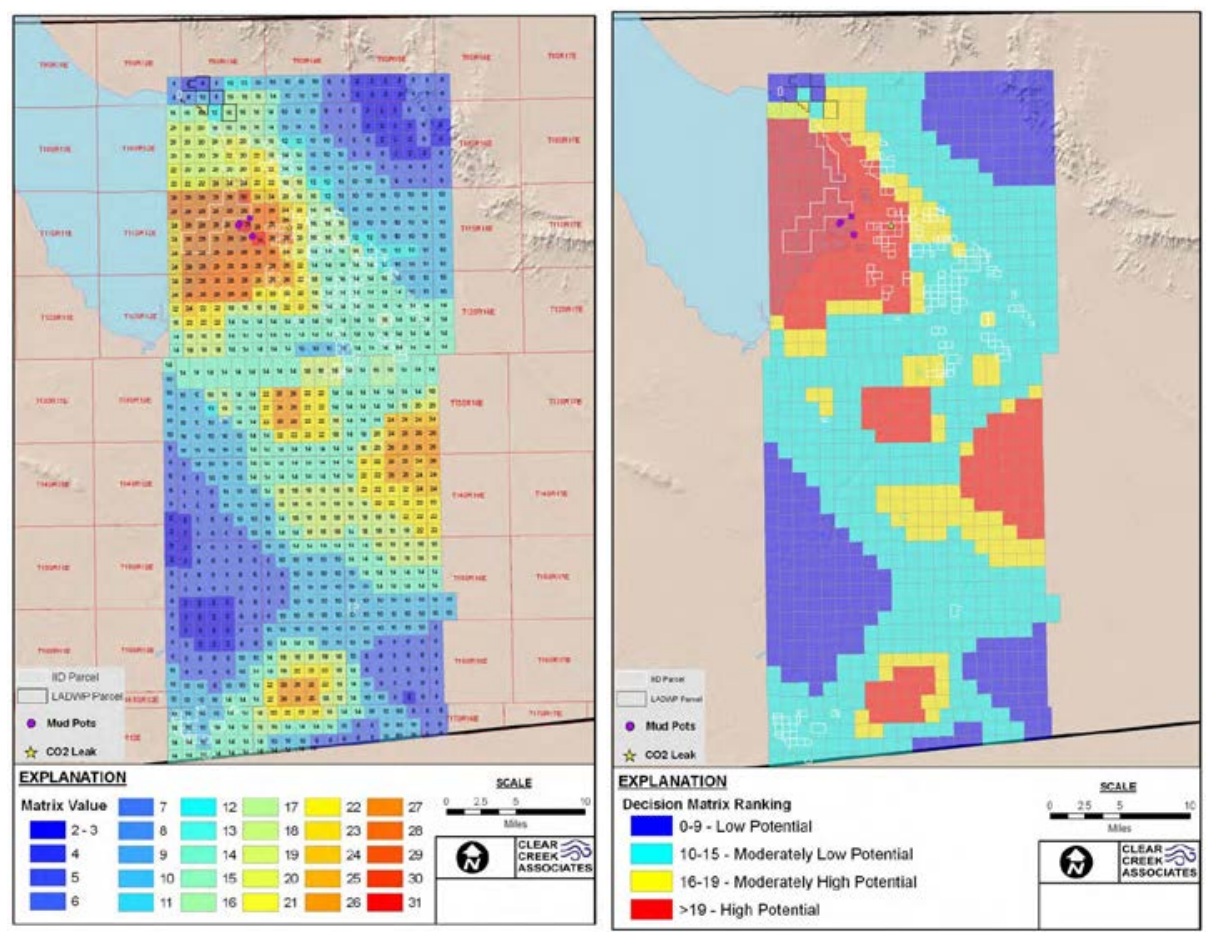

Source: EES Consulting 2013

Figure 9. Geothermal remote sensing prioritization matrix.

Left: Matrix Values - Prioritized According to Geothermal Resource Potential; Right: Ranked Values According to Geothermal Resource Potential

\section{Geochemistry}

Geothermal brines of Imperial Valley are usually hypersaline, having between 150,000 parts per million (ppm) and 300,000 ppm total dissolved solids (TDS) content. The Salton Sea geothermal area has the highest salinity in the region. However, there are some geothermal areas with relatively low salinity brines, such as the Truckhaven and East Mesa areas (4,500 ppm to 7,500 ppm, respectively). In the KGRAs of Imperial County, resource temperatures range from $250^{\circ} \mathrm{F}$ to $600^{\circ} \mathrm{F}$ (Table 5). However, based on discussions with contacts from an existing plant in the 
region, reservoir depths of 4,000-8,000, and a maximum reservoir temperature of $550^{\circ} \mathrm{F}$ are a more realistic range for the region.

Table 5. Temperature and Total Dissolved Solids Content of Geothermal Areas in Imperial County

\begin{tabular}{|l|c|c|c|}
\hline $\begin{array}{l}\text { Geothermal } \\
\text { Areas }\end{array}$ & $\begin{array}{c}\text { Reservoir } \\
\text { Depth }(\mathrm{ft})\end{array}$ & $\begin{array}{c}\text { Average Reservoir } \\
\text { Temperature }\left({ }^{\circ} \mathrm{F}\right)\end{array}$ & \begin{tabular}{c} 
TDS Content (ppm) \\
\hline Salton Sea
\end{tabular} \\
\hline, 000 & 600 & $250,000-300,000$ \\
\hline East Mesa & 6,000 & 350 & 7,500 \\
\hline Heber & 6,000 & 360 & 14,000 \\
\hline North Brawley & 7,000 & 525 & 150,000 \\
\hline East Brawley & 12,000 & 400 & 150,000 \\
\hline South Brawley & 13,500 & 500 & 250,000 \\
\hline Niland & N/A & N/A $/ A$ \\
\hline Mount Signal & N/A & 275 & N/A \\
\hline Dunes & 4,000 & 250 & N/A \\
\hline Superstition & N/A & N/A & N/A \\
\hline Gountain & 5,000 & 250 & N/A \\
\hline Truckhaven & 7,000 & 350 & 4,500 \\
\hline Westmorland & 7,000 & 325 & 26,000 \\
\hline
\end{tabular}

Source: Heuberger 2006

The brine compositions may vary from well to well depending on the depth of production and the temperature of the different parts of the reservoir. In addition, the composition of a particular well may vary as a function of the total production time, the rate of flow, and the nature of the underlying sediments. Table 6 represents the average concentrations of elements in the brine and gas phase of geothermal fluids in KGRAs (Heuberger 2006). 
Table 6. Typical Geothermal Brine and Gas Chemistry of Imperial Valley KGRAs

\begin{tabular}{|c|c|c|c|c|c|c|}
\hline \multicolumn{2}{|c|}{ Dissolved Solids (in mg/L) } & Salton Sea & Westmorla & Brawley & Heber & East \\
\hline Sodium & $\mathrm{Na}$ & $52,000.00$ & $10,000.00$ & $\begin{array}{r}22,000.0 \\
0\end{array}$ & $\begin{array}{r}4,200.0 \\
0\end{array}$ & $2,600.00$ \\
\hline \multicolumn{2}{|l|}{ Potassium } & $14,000.00$ & $1,400.00$ & $3,800.00$ & 260 & 190 \\
\hline \multicolumn{2}{|l|}{ Calcium } & $24,000.00$ & 690 & $8,100.00$ & 880 & 130 \\
\hline Magnesium & $\mathrm{Mg}$ & 106 & 188 & 34 & 5.4 & 3.4 \\
\hline Chloride & $\mathrm{Cl}$ & 145,000 & $18,000.00$ & $\begin{array}{r}46,000.0 \\
0\end{array}$ & $\begin{array}{r}7,900.0 \\
0\end{array}$ & $3,900.00$ \\
\hline Sulfate & $\mathrm{SO}_{4}$ & 84 & 57 & - & 99 & 155 \\
\hline Bicarbonate & $\mathrm{HCO}_{3}$ & 140 & $2,900.00$ & 49 & 27 & 490 \\
\hline Arsenic & As & 11 & - & 2.6 & 0.1 & 0.16 \\
\hline \multicolumn{2}{|l|}{ Boron } & 350 & 63 & 140 & 14 & 5.4 \\
\hline \multicolumn{2}{|l|}{ Barium } & 433 & - & 363 & 3.8 & 2.2 \\
\hline \multicolumn{2}{|l|}{ Copper } & 4 & 0.07 & 0.11 & 0.53 & 0.03 \\
\hline \multicolumn{2}{|l|}{ Fluoride } & 9 & 2.24 & - & 1.6 & 2 \\
\hline \multicolumn{2}{|l|}{ Iron } & $2,300.00$ & 0.3 & 65 & 22 & 2.2 \\
\hline Lithium & $\mathrm{Li}$ & 211 & 48 & 100 & 9.5 & 6.3 \\
\hline \multicolumn{2}{|l|}{ Manganese } & $1,200.00$ & 2.8 & 190 & 2.7 & 0.42 \\
\hline \multicolumn{2}{|l|}{ Nickel } & 4 & - & - & 0.03 & - \\
\hline \multicolumn{2}{|l|}{ Lead } & 100 & 3.8 & 1.1 & 1.9 & 0.09 \\
\hline \multicolumn{2}{|l|}{ Strontium } & 500 & - & 340 & 53 & 38 \\
\hline \multicolumn{2}{|l|}{ Zinc } & 660 & 0.04 & 14 & 0.83 & 0.07 \\
\hline \multicolumn{4}{|c|}{ Salton Sea } & \multicolumn{3}{|c|}{ East Mesa } \\
\hline \multicolumn{2}{|c|}{$\begin{array}{c}\text { Non-condensable Gases (in } \\
\mathrm{mg} / \mathrm{kg} \text { ) }\end{array}$} & \multicolumn{2}{|c|}{ Range } & Mean & Range & Mean \\
\hline Hydrogen Sulfide & $\mathrm{H}_{2} \mathrm{~S}$ & \multicolumn{2}{|c|}{$1.6-6.0$} & 3.2 & $0.12-1.6$ & 0.54 \\
\hline Ammonia & $\mathrm{NH}$ & \multicolumn{2}{|c|}{$20-40$} & 35 & $1.3-8.1$ & 4.5 \\
\hline Carbon Dioxide & $\mathrm{CO}_{4}$ & & 1,700 & $270-2,300$ & 1,100 \\
\hline Methane & $\mathrm{CO}_{4}$ & \multicolumn{2}{|c|}{$\begin{array}{c}1,100-3,800 \\
10-M a r\end{array}$} & 6 & $4.0-56$ & 33 \\
\hline Hydrogen & $\mathrm{H}_{2}$ & $0.0016-$ & 0.002 & 0.0018 & $\begin{array}{l}0.005- \\
0.007\end{array}$ & 0.0064 \\
\hline
\end{tabular}

Source: Heuberger 2006

\section{Volumetric Resource Assessment}

The primary method applied in USGS assessments for evaluating the production potential of identified geothermal systems is the volume method. In this method, the recoverable heat is estimated from the thermal energy available in a reservoir of uniformly porous and permeable rock using a thermal recovery factor, $\mathrm{R}_{\mathrm{g}}$, which accounts for the fraction of the reservoir's energy that can be turned into power.

The electric power generation potential from an identified geothermal system depends on the thermal energy present in the reservoir, $\mathrm{q}_{\mathrm{R}}$, the amount of thermal energy that can be extracted from the reservoir at the wellhead, $\mathrm{q}_{\mathrm{wH}}$, and the efficiency with which that wellhead thermal energy can be converted to electric power. This information is relevant to the volumetric resource assessment, as the thermal energy contained in the reservoir is an important piece of the overall calculation of the ultimate electric power generation potential. 
The amount and quality of technical data available from the geothermal resource areas is highly variable. On one hand, geothermal areas with existing facilities with long production histories or have enough drilling information to prove the existence of commercial production conditions, can allow a reasonably accurate assessment of the ultimate potential and electricity generation capacity of the field. On the other hand, for geothermal areas that have been identified from surface exploration, but with no deep drilling to confirm the presence of a commercial reservoir, the potential and electric generation capacity can only be assumed based on averages at other fields in similar settings.

In early stages of geothermal resource assessment, electrical power generation capacities of the resource areas can be estimated using a probabilistic (Monte Carlo) method applied to a calculation of heat in place (the stored thermal energy in a geothermal reservoir). This probabilistic approach is based on volumetric assessment of the geothermal reservoir. To be able to perform volumetric calculations, some geothermal system and reservoir variables should be estimated. These variables are:

- Surface area of the geothermal system

- Thickness of the system (vertical distance between top and bottom surfaces of the reservoir rocks)

- Reservoir temperature

- Recovery factor

- Porosity of the rocks

- Heat and density of the rock and water.

To take uncertainties of these criteria into account, a most-likely value is selected, together with a minimum value and a maximum value that define an approximately normal probability distribution around the most-likely value. The minimum, most-likely, and maximum values of each criterion are then used in probabilistic simulation (based on Monte Carlo random-number sampling) to calculate estimated generation capacity based on the accessible heat in place at the resource area. Results are expressed in terms of MW capacity for life-time of the power plant (i.e., 30 years). In order to convert thermal energy into electrical energy, there are some other parameters to be estimated such as: electric conversion coefficient, load factor, system cut-off temperature, and system delta temperature (the difference between inlet and outlet design temperatures, which is used to calculate the exergy, or maximum useful energy, of the system).

Results of probabilistic calculations can be expressed in terms of minimum (90\% cumulative probability), most-likely (modal), mean, and the standard deviation of the mean. It must be emphasized that the generation capacity estimate is based on calculated heat in place. This does not guarantee that a given resource in which there has been little or no drilling will have the reservoir permeability required to allow commercial production of hot water or steam to a power plant. That can be established only by drilling and testing the production zone.

One of the most recent electricity generation capacity estimates based on volumetric assessment calculations was conducted by GeothermEx for the California Energy Commission in 2004. This estimate was based on a thirty-year production life. Table 7 summarizes resource capacity 
estimates (GeothermEx 2004), as well as the reservoir volume from USGS, and surface areas estimates (Heuberger 2006) for each geothermal area in Imperial County.

Table 7. Electricity Generation Capacity Estimates for Imperial County Geothermal Areas Using Volumetric Assessment Methods

\begin{tabular}{|c|c|c|c|c|c|c|}
\hline $\begin{array}{l}\text { Geothermal } \\
\text { Areas }\end{array}$ & $\begin{array}{l}\text { Reservoir } \\
\text { Volume } \\
\text { Estimate } \\
\left(\mathrm{km}^{3}\right)^{*}\end{array}$ & $\begin{array}{l}\text { Minimum } \\
\text { Resource } \\
\text { Capacity } \\
\text { (MW) }^{\dagger}\end{array}$ & $\begin{array}{l}\text { Most } \\
\text { Likely } \\
\text { Generation } \\
\text { Capacity } \\
(\mathrm{MW})^{\dagger}\end{array}$ & $\begin{array}{l}\text { Mean } \\
\text { Resource } \\
\text { capacity } \\
(\mathrm{MW})^{\dagger}\end{array}$ & $\begin{array}{l}\text { Nameplate } \\
\text { Capacity in } \\
\text { January } \\
2015(\mathrm{MW}) * *\end{array}$ & $\begin{array}{l}\text { Most Likely } \\
\text { Developable } \\
\text { Capacity (MW) }\end{array}$ \\
\hline Salton Sea & 127.7 & 1,350 & 1,750 & 1,880 & 402.2 & $\begin{array}{c}1,348 \\
\left(1,064^{\dagger \dagger}\right)\end{array}$ \\
\hline East Mesa & 30 & 119 & 148 & 167 & 120.5 & 28.5 \\
\hline Heber & 20 & 109 & 142 & 158 & 142.5 & 16 \\
\hline North Brawley & 9 & 88 & 135 & 144 & 50 & 85 \\
\hline East Brawley & 24 & 85 & 129 & 138 & 0 & 129 \\
\hline $\begin{array}{l}\text { South } \\
\text { Brawley }\end{array}$ & 2 & 45 & 62 & 70 & 0 & 62 \\
\hline Niland & N/A & 59 & 76 & 92 & 0 & $76^{\top \top}$ \\
\hline Mount Signal & 3.1 & 12 & 19 & 29 & 0 & 19 \\
\hline Dunes & 1.95 & 7.4 & 11 & 18 & 0 & 11 \\
\hline $\begin{array}{l}\text { Superstition } \\
\text { Mountain }\end{array}$ & N/A & 6 & 10 & 15 & 0 & 10 \\
\hline Glamis & $\mathrm{N} / \mathrm{A}$ & 4 & 6 & 11 & 0 & 6 \\
\hline Truckhaven & $\mathrm{N} / \mathrm{A}$ & N/A & $50^{n \prime}$ & N/A & 0 & 50 \\
\hline Westmorland & N/A & $\mathrm{N} / \mathrm{A}$ & N/A & $\mathrm{N} / \mathrm{A}$ & 0 & N/A \\
\hline TOTAL & 217.75 & $1,884.4$ & 2,448 & 2,722 & 715.2 & $1,840.5$ \\
\hline
\end{tabular}

The most likely field generation capacity for all Imperial County geothermal areas is 2,448 MW. After subtracting the existing nameplate capacity from this figure, the estimated remaining undeveloped capacity is calculated to be $1,840.5 \mathrm{MW}$. The most likely developable capacity of the Salton Sea KGRA is 1,348 MW; however, in a 2014 study, this number was updated (but not published) by GeothermEx to 1,064 MW. For the purposes of this analysis, the published estimate in 2006 of 1,348 MW will be utilized. 


\section{Resource Estimates for the Salton Sea KGRA}

The geothermal resource potential of Salton Sea area has been investigated since the late 1970s and there are many different published estimates for long-term electric power production potential. The estimates are based on the investigators' assessments of reservoir area, thickness, volume, temperature, porosity, permeability, fluid mass and replacement capacity, stored heat, heat recoverability, and heat-to-electricity conversion efficiency. These estimates are listed in Table 8.

Table 8. Summary of Published Salton Sea Geothermal Area Resource Estimates

\begin{tabular}{|l|c|}
\hline Reference Study & Resource Estimate (MW) for $\mathbf{3 0}$ years \\
\hline Ermak, 1977 & 4,000 \\
\hline Younker and Kasameyer, 1978 & 1,300 to 8,700 \\
\hline Brook et al. , 1979 & 3,400 \\
\hline Meidav and Howard, 1979 & 30,000 \\
\hline Biehler and Lee, 1997 & 17,500 \\
\hline Elders,1989 & 2,500 \\
\hline Hulen et al. , 2002 & 2330 \\
\hline GeothermEx, 2004 & 1,750 \\
\hline EES Consulting, 2013 & 2,900 \\
\hline
\end{tabular}

The Salton Sea KGRA is widely considered by many geothermal industry leaders as the best opportunity for growth in California in the near term. However, the majority of the proven resource is located within the offshore part of the area (Figure 10). The onshore portion of the geothermal reservoir in the Salton Sea area constitutes only $38.6 \%$ of the total, whereas the offshore part constitutes $61.4 \%$ (Hulen et al. 2002). 

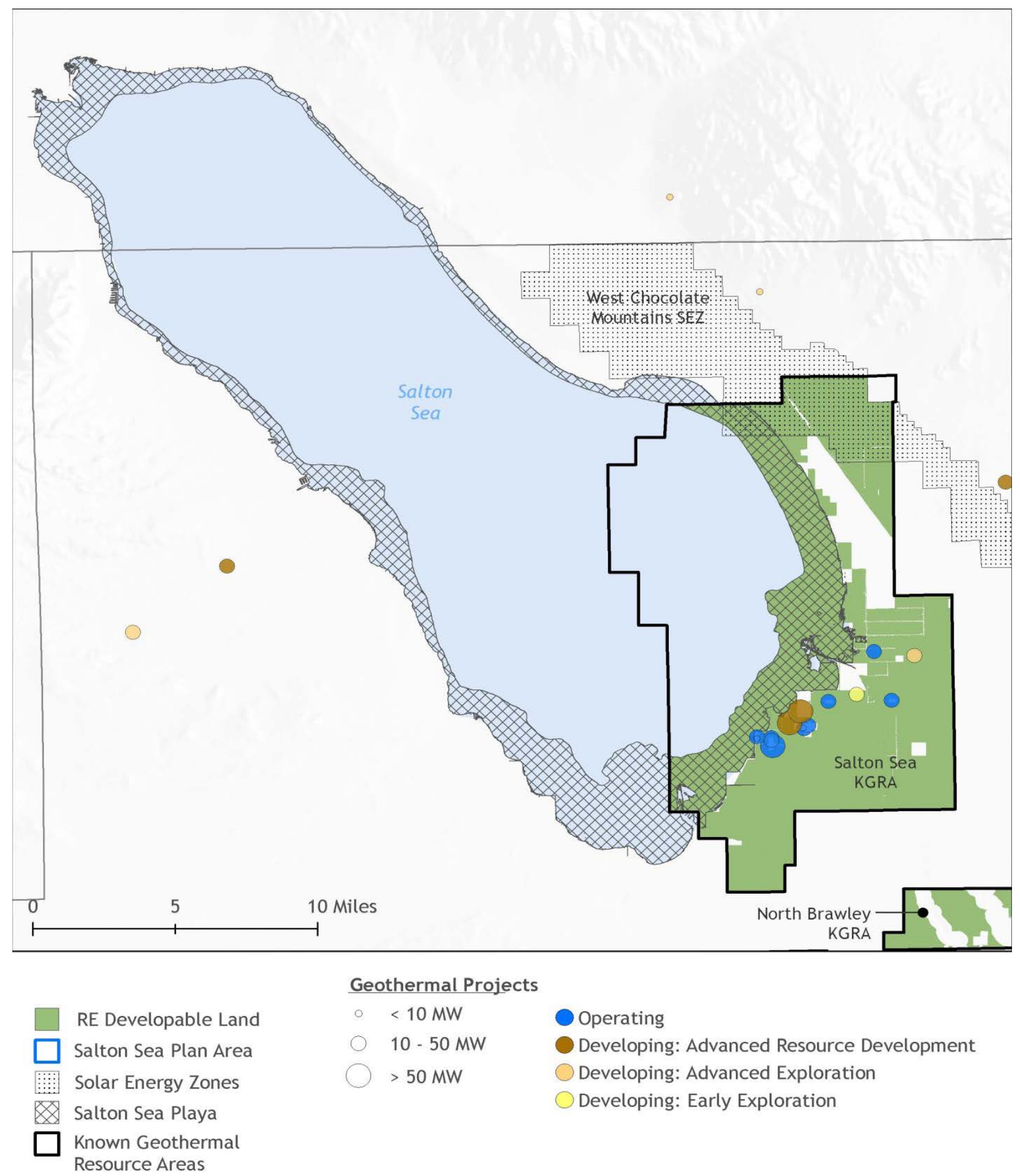

Data Sources: National Renewable Energy Laboratory; Desert Renewable Energy Conservation Plan; Riverside County, CA; Imperial County, CA; Imperial Irrigation District; BLM; NREL Geothermal Prospector 2014.

Figure 10: Offshore portion of Salton Sea KGRA and recession estimate of the shoreline in 25 years.

It has been estimated that the offshore part of Salton Sea KGRA's potential is 1,430 MW. GeothermEx does not have a separation between onshore and offshore resources, but if the ratio 
referenced above (Hulen et al. 2002) is utilized, the offshore part of the resource is calculated to be 1,075 MW. EES Consulting forecasts the possible offshore geothermal generation as 1,660 MW, including the low temperature gradient portion of the reservoir. The shoreline of the Salton Sea is receding at the estimated rates described in Figure 11. The current total area of water in the Salton Sea KGRA is calculated at 52,848 acres, which will recede to 34,854 acres, leaving 17,994 acres of playa area in 2030. This recession will likely allow for the development of offshore resource potential at Salton Sea KGRA (Figure 11). Based on the total water area in the Salton Sea KGRA, unit power generation capacity is calculated as $20 \mathrm{~kW} /$ acre (GeothermEx 2004), $27 \mathrm{~kW} /$ acre (Heuberger 2006), and $31.5 \mathrm{~kW}$ /acre (EES 2013). Then, the additional power generation capacity is calculated by multiplying the unit capacity with the total revealed playa area of Salton Sea in every five years interval (Figure 11). Maximum developable capacity at the Salton Sea offshore KGRA is estimated to reach up to 565 MW in 2030.

Table 9. Onshore and Offshore Portions of Salton Sea KGRA Based on Most Recent Resource Potential Estimates

\begin{tabular}{|l|c|c|c|}
\hline Reference Study & $\begin{array}{l}\text { Total Resource } \\
\text { Estimate (MW) }\end{array}$ & $\begin{array}{l}\text { Onshore Resource } \\
\text { Estimate (MW) }\end{array}$ & $\begin{array}{l}\text { Offshore playa } \\
\text { Resource } \\
\text { Estimate (MW) }\end{array}$ \\
\hline Hulen et al. 2002 & 2,330 & 900 & 1,430 \\
\hline GeothermEx 2006 & 1,750 & 675 & 1,075 \\
\hline EES Consulting 2013 & 2,900 & 1,240 & 1,660 \\
\hline
\end{tabular}

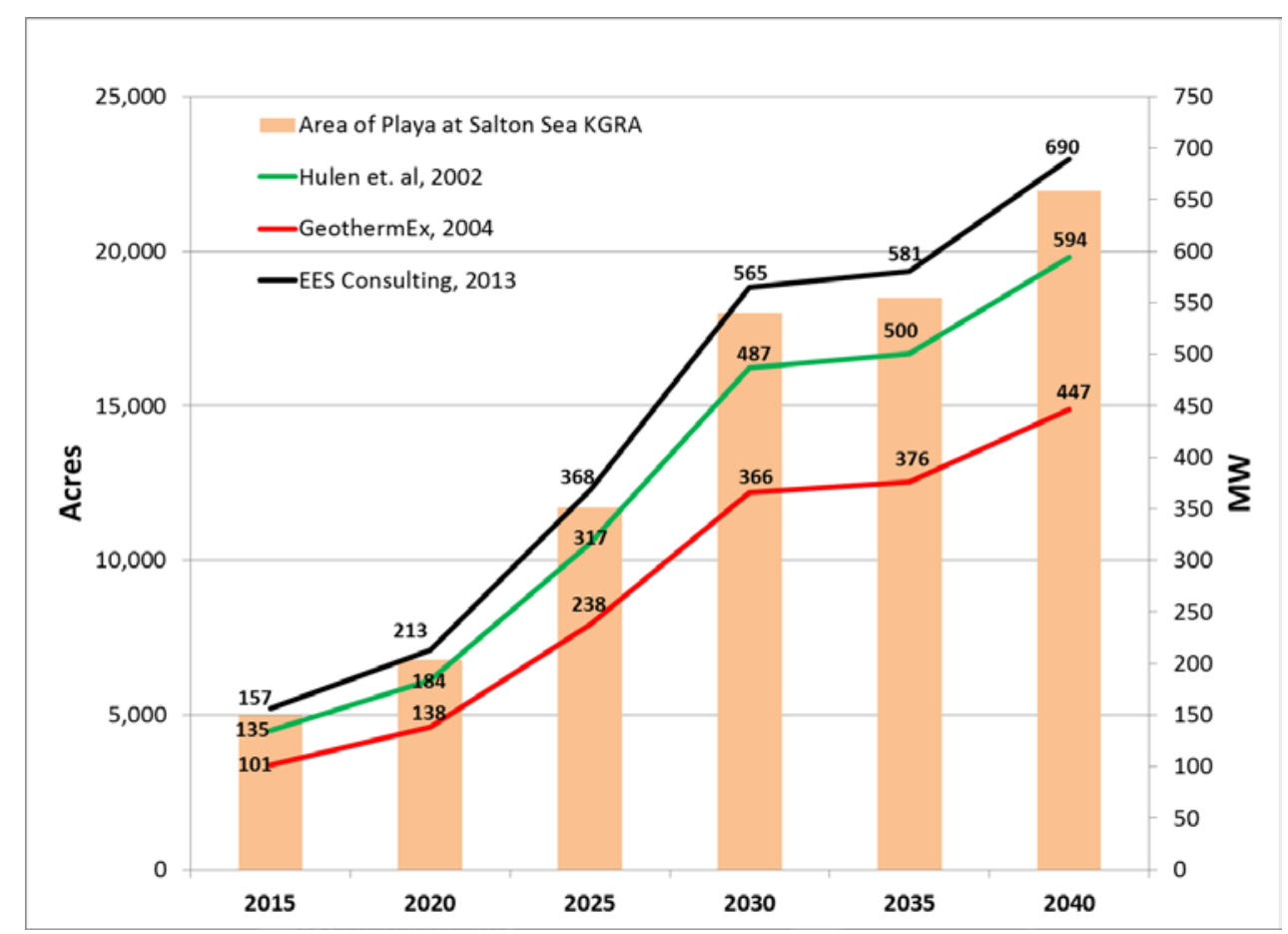

Figure 11. Potential development of offshore Salton Sea KGRA based on the shoreline recession in 25 years. 
The generation figures in Table 10 assume a net capacity factor of $80 \%$. For a water-cooled flash plant, a capacity factor of $94 \%$ was estimated, but in order to provide a conservative estimate of the likely generation after accounting for parasitic loads, a net capacity factor of $80 \%$ was assumed (Mines et al. 2015). Although there is a high capacity potential for this region, several key caveats for the region must be noted. Much of the geothermal resource in the Salton Sea is extremely high temperature, requires pumping of the resource, and often contains damaging silica that can result in scaling. These operational challenges can result in lower net capacity factors and higher operation and maintenance (O\&M) costs than those of other regions. Based on industry knowledge, net power generation can be up to $40 \%$ less than gross power capacity (i.e., nameplate).

Second, in the oil and gas industry, directional drilling may reach up to 1 mile offset distance (Billman et al. 2000). However, in the geothermal industry, the typical directional well offset distance is between $1 / 4$ and $1 / 2$ mile (Kuyumcu et al. 2013). Therefore, instead of directional wells, future projects will likely have to be constructed on playa with additional construction cost. Offshore playa development is estimated by an industry source to result in at least a $10 \%$ increase over typical geothermal costs.

Finally, there is already a significant amount of existing geothermal capacity in the region, with $600 \mathrm{MW}$ of existing and operating plants as shown in Figure 12. Of these geothermal fields, the greatest concentration of projects is located within the Salton Sea field. 


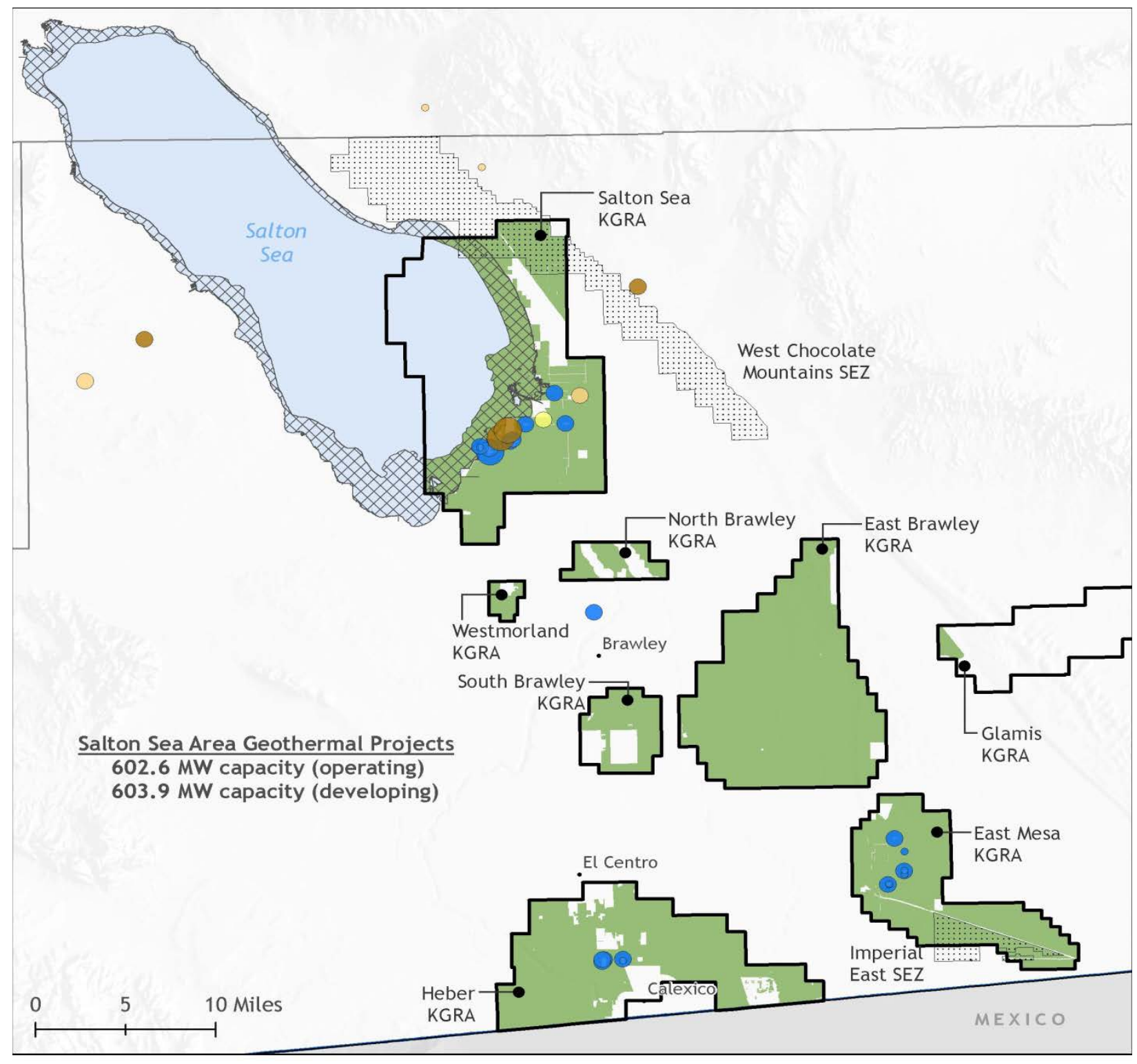

602.6 MW capacity (Operating)

603.9 MW capacity (developing)

\section{Geothermal Projects}

RE Developable Land Salton Sea Plan Area

Solar Energy Zones

Salton Sea Playa

Known Geothermal

Resource Areas

$$
\begin{aligned}
\circ & <10 \mathrm{MW} \\
& 10-50 \mathrm{MW} \\
> & >50 \mathrm{MW}
\end{aligned}
$$

Operating

Developing: Advanced Resource Development Developing: Advanced Exploration Developing: Early Exploration

Data Sources: National Renewable Energy Laboratory; Desert Renewable Energy Conservation Plan; Riverside County, CA; Imperial County, CA; Imperial Irrigation District; BLM; NREL Geothermal Prospector 2014.

Figure 12. Existing and developing geothermal plants. 
Table 10. Developable Geothermal Capacity by 2030

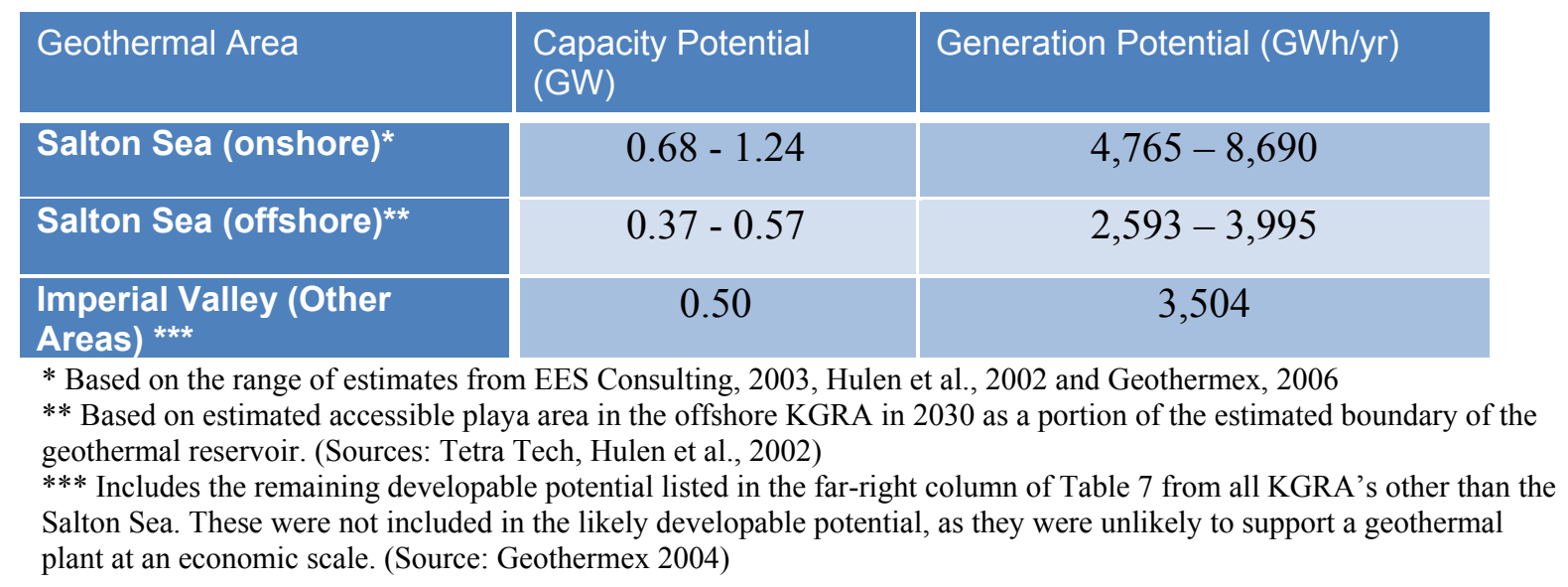

\subsection{Solar}

Given the generally strong solar resource in the Salton Sea area (between 6 and 7.8 $\mathrm{kWh} / \mathrm{m} 2 /$ day), a variety of solar electric or solar thermal technologies may be suitable for development within the region.

\subsubsection{Photovoltaics}

As shown in Figure 13, the Salton Sea area already has considerable operating and planned PV capacity. 

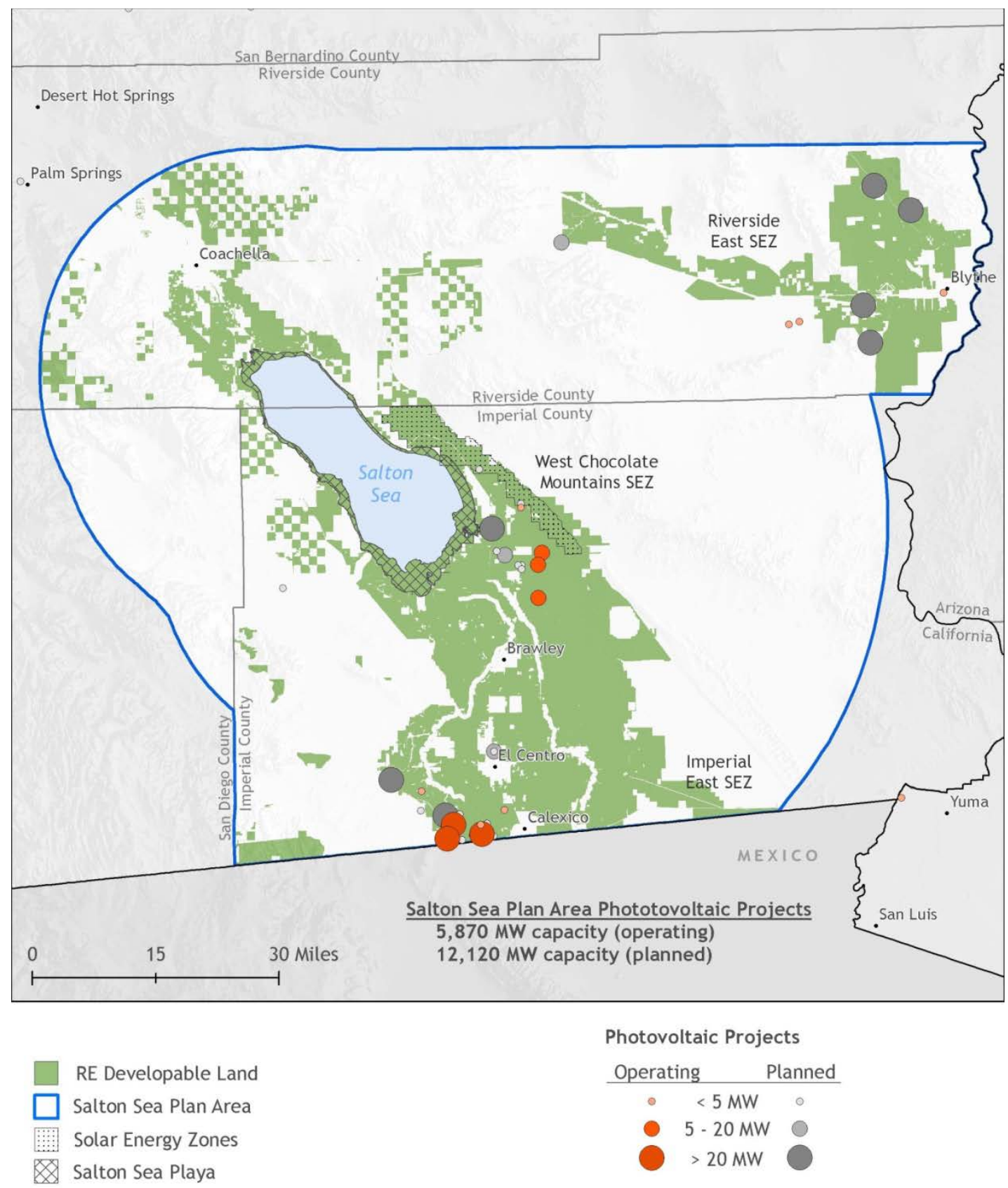

Photovoltaic Projects

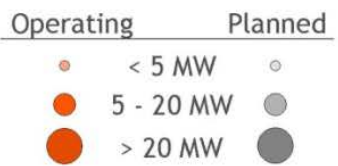

Data Sources: National Renewable Energy Laboratory; Desert Renewable Energy Conservation Plan; Riverside County, CA; Imperial County, CA; Imperial Irrigation District; BLM; Ventyx Velocity Suite 2014.

Figure 13. Existing and planned PV projects.

The total solar PV resource in the Salton Sea Plan area is show in Table 11. This assumes a 20\% capacity factor, and assumes average land use of 7.9 acres/MWac for large-scale PV plants. Based on a 2013 NREL study of $72 \%$ of all U.S. utility solar capacity, solar PV typically occupies between 7 acres and 10 acres/MW, with mean and median values of 7.9 and 8.5 , respectively. Smaller utility-scale plants under $20 \mathrm{MW}$ have been demonstrated to use a mean 
6.3 acres/MW (Ong et al. 2013). Generation is estimated using SAM 2015-01-30 ${ }^{9}$ for a fixed-tilt, utility-scale PV plant using the Imperial, CA weather file.

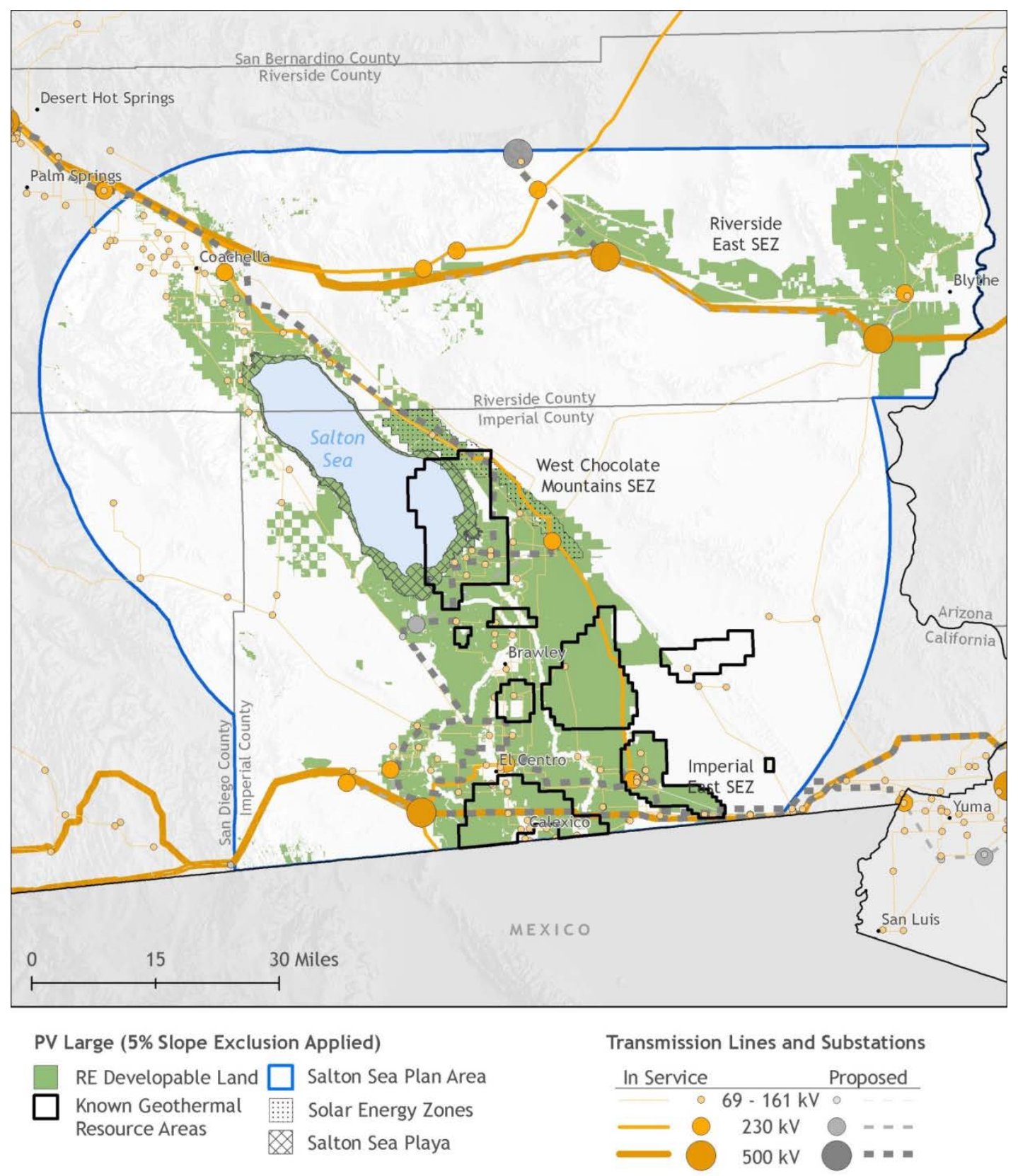

Data Sources: National Renewable Energy Laboratory; Desert Renewable Energy Conservation Plan; Riverside County, CA; Imperial County, CA; Imperial Irrigation District; BLM; Ventyx Velocity Suite 2014.

Figure 14. Developable solar PV resource.

${ }^{9}$ NREL System Advisor Model (SAM), https://sam.nrel.gov/_accessed 6/9/15. 
Although the total capacity potential is extremely large, the developable potential is significantly smaller, due to transmission proximity, land access, financing, and utility demand constraints, among others. Of the total available area under BLM ownership, 203,051 acres fall within the SEZs.

Construction of solar PV on the playa as a potential dust-mitigation measure was also examined. The Los Angeles Department of Water and Power (LADWP) has recently completed a $500 \mathrm{~kW}$ pilot project exploring solar PV development on the Owens Lakebed. Construction on the playa required additional costs for mobilization and transportation to work within the loose soil conditions (such as an access road and pre-existing gravel cover) but the system is operational. Development of solar PV on the playa may allow for an additional potential revenue stream for Salton Sea restoration, as the playa land is predominantly owned by the IID, while simultaneously providing a dust mitigation benefit from ground coverage by the panels. Additional geotechnical analysis of the Salton Sea playa would be required to determine whether development of solar PV would be technically feasible.

Table 11. Developable Solar PV Resource

\begin{tabular}{|c|c|c|c|c|c|c|}
\hline Technology & $\begin{array}{l}\text { Total } \\
\text { Capacity } \\
\text { Potential } \\
\text { (GWac) }\end{array}$ & $\begin{array}{l}\text { Generation } \\
\text { Potential } \\
\text { (GWh/yr) }\end{array}$ & $\begin{array}{l}\text { Small } \\
\text { Sub. } \\
\text { Capacity } \\
\text { Potential } \\
\text { (GWac) } \\
1 \mathrm{mi} .\end{array}$ & $\begin{array}{l}\text { Large } \\
\text { Sub. } \\
\text { Capacity } \\
\text { Potential } \\
\text { (GWac) } \\
1 \mathrm{mi} .\end{array}$ & $\begin{array}{l}\text { Small } \\
\text { Sub. } \\
\text { Capacity } \\
\text { Potential } \\
\text { (GWac) } \\
5 \mathrm{mi} .\end{array}$ & $\begin{array}{l}\text { Large } \\
\text { Sub. } \\
\text { Capacity } \\
\text { Potential } \\
\text { (GWac) } \\
5 \mathrm{mi} .\end{array}$ \\
\hline $\begin{array}{c}\text { Solar PV } \\
\text { (onshore) }\end{array}$ & 103 & $2.10 \times 10^{5^{*}}$ & 1.8 & .007 & 31.9 & 9.3 \\
\hline
\end{tabular}

*This PV estimate comes from SAM's default utility-scale PV case. A 110 MWdc (100MWac) fixed-tilt solar field using Imperial, CA weather data generates $204 \mathrm{GWhac} / \mathrm{yr}$. This is calculated as $2040 \mathrm{GWhac} / \mathrm{yr}$ per GWac capacity. Small substations are defined as between 138 and $230 \mathrm{kV}$ and large substations defined as $500 \mathrm{kV}$.

Data Sources: National Renewable Energy Laboratory; Desert Renewable Energy Conservation Plan; Riverside County, CA; Imperial County, CA; Imperial Irrigation District; BLM. Ventyx Velocity Suite 2014. 


\subsubsection{Concentrating Solar Power}

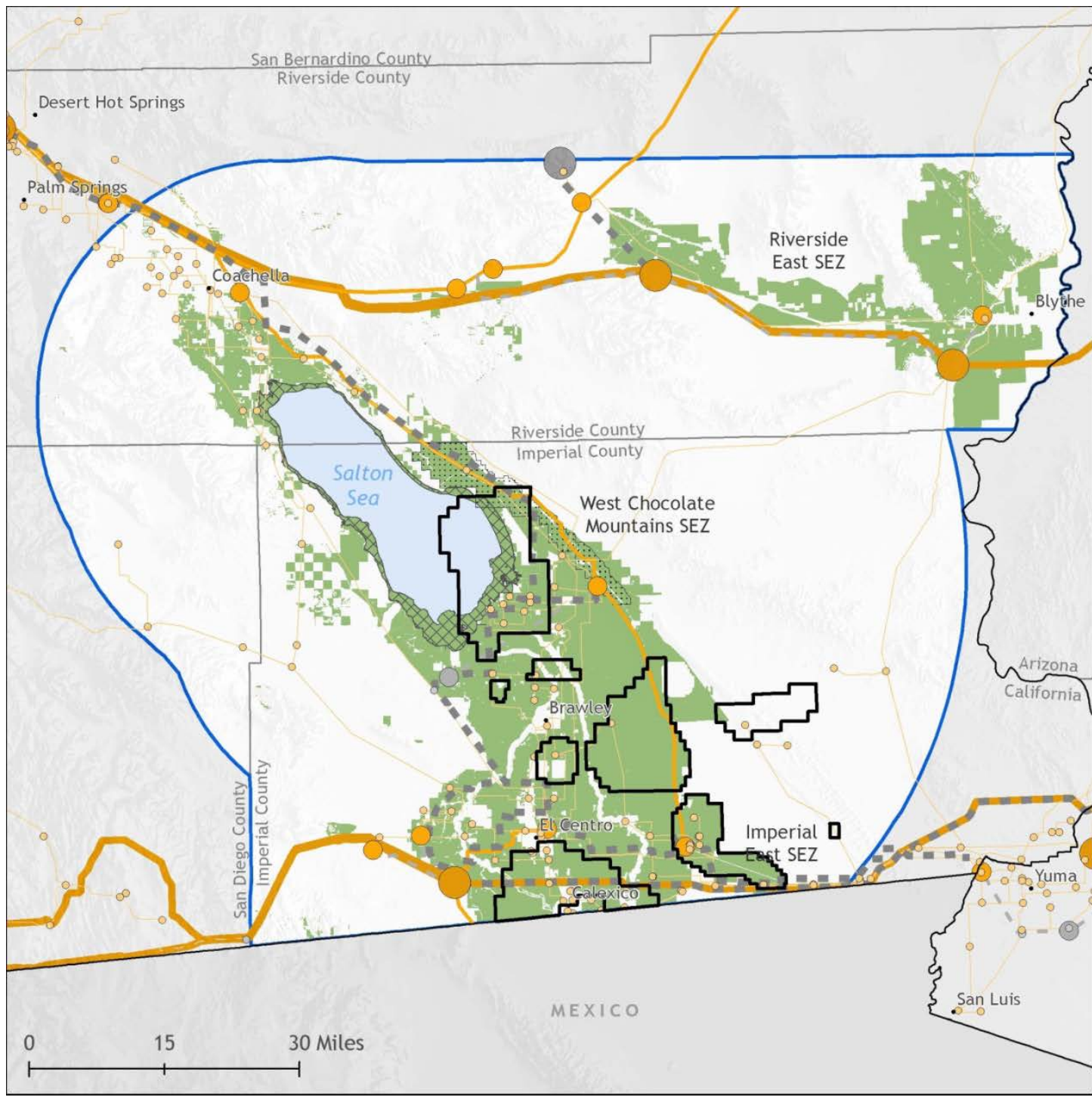

CSP (3\% Slope Exclusion Applied)

RE Developable Land Known Geothermal Resource Areas

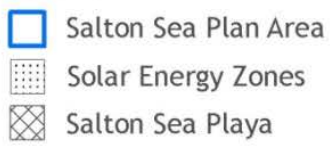

Transmission Lines and Substations

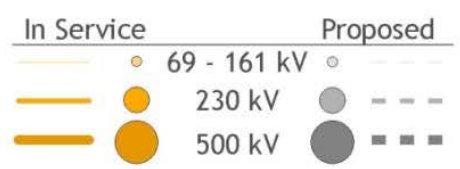

Data Sources: National Renewable Energy Laboratory; Desert Renewable Energy Conservation Plan; Riverside County, CA; Imperial County, CA; Imperial Irrigation District; BLM; Ventyx Velocity Suite 2014.

\section{Figure 15. Developable concentrating solar power resource.}

The total CSP resource in the Salton Sea Plan area is shown in Table 12. Due to the strong solar resource and relatively low slope constraints, there is a very high technical potential for CSP projects in the Salton Sea study area. However, as was noted in the solar PV section, while this capacity may be technically feasible, CSP development is also constrained by numerous other factors, including its relative economic competitiveness within the region. Capacity factors for various CSP technologies vary widely, and generation potential has been given as a range 
between 25\% and 49\%. The CSP potential was estimated using the default Parabolic Trough case (Physical Trough model) in SAM 2015-01-30. This plant is assumed to have six hours of thermal energy storage has a calculated capacity factor of $42 \%$ using the Imperial, CA weather file.

Table 12. Developable CSP Resource

\begin{tabular}{|c|c|c|c|c|c|c|}
\hline Technology & $\begin{array}{l}\text { Total } \\
\text { Capacity } \\
\text { Potential } \\
\text { (GWac) }\end{array}$ & $\begin{array}{l}\text { Generation } \\
\text { Potential } \\
\text { (GWh/yr) }\end{array}$ & $\begin{array}{l}\text { Small } \\
\text { Sub. } \\
\text { Capacity } \\
\text { Potential } \\
\text { (GWac) } \\
1 \mathrm{mi} .\end{array}$ & $\begin{array}{l}\text { Large } \\
\text { Sub. } \\
\text { Capacity } \\
\text { Potential } \\
\text { (GWac) } \\
1 \mathrm{mi} .\end{array}$ & $\begin{array}{l}\text { Small } \\
\text { Sub. } \\
\text { Capacity } \\
\text { Potential } \\
\text { (GWac) } \\
5 \mathrm{mi} .\end{array}$ & $\begin{array}{l}\text { Large } \\
\text { Sub. } \\
\text { Capacity } \\
\text { Potential } \\
\text { (GWac) } \\
5 \mathrm{mi} .\end{array}$ \\
\hline $\begin{array}{l}\text { Solar CSP } \\
\text { (onshore) }\end{array}$ & 77 & $2.80 \times 10^{5^{*}}$ & 1.3 & .006 & 23.9 & 7.3 \\
\hline
\end{tabular}

*This CSP estimate comes from SAM's default Physical Trough case. A 100 MWac,net trough plant with 6 hours of thermal energy storage using Imperial, CA weather data generates $364 \mathrm{GWhac} / \mathrm{yr}$. This is calculated as 3,640 GWhac/yr per GWac capacity. Small substations are defined as between $138 \mathrm{kV}$ and $230 \mathrm{kV}$ and large substations defined as $500 \mathrm{kV}$. Data Sources: National Renewable Energy Laboratory; Desert Renewable Energy Conservation Plan; Riverside County, CA; Imperial County, CA; Imperial Irrigation District; BLM. Ventyx Velocity Suite 2014. 


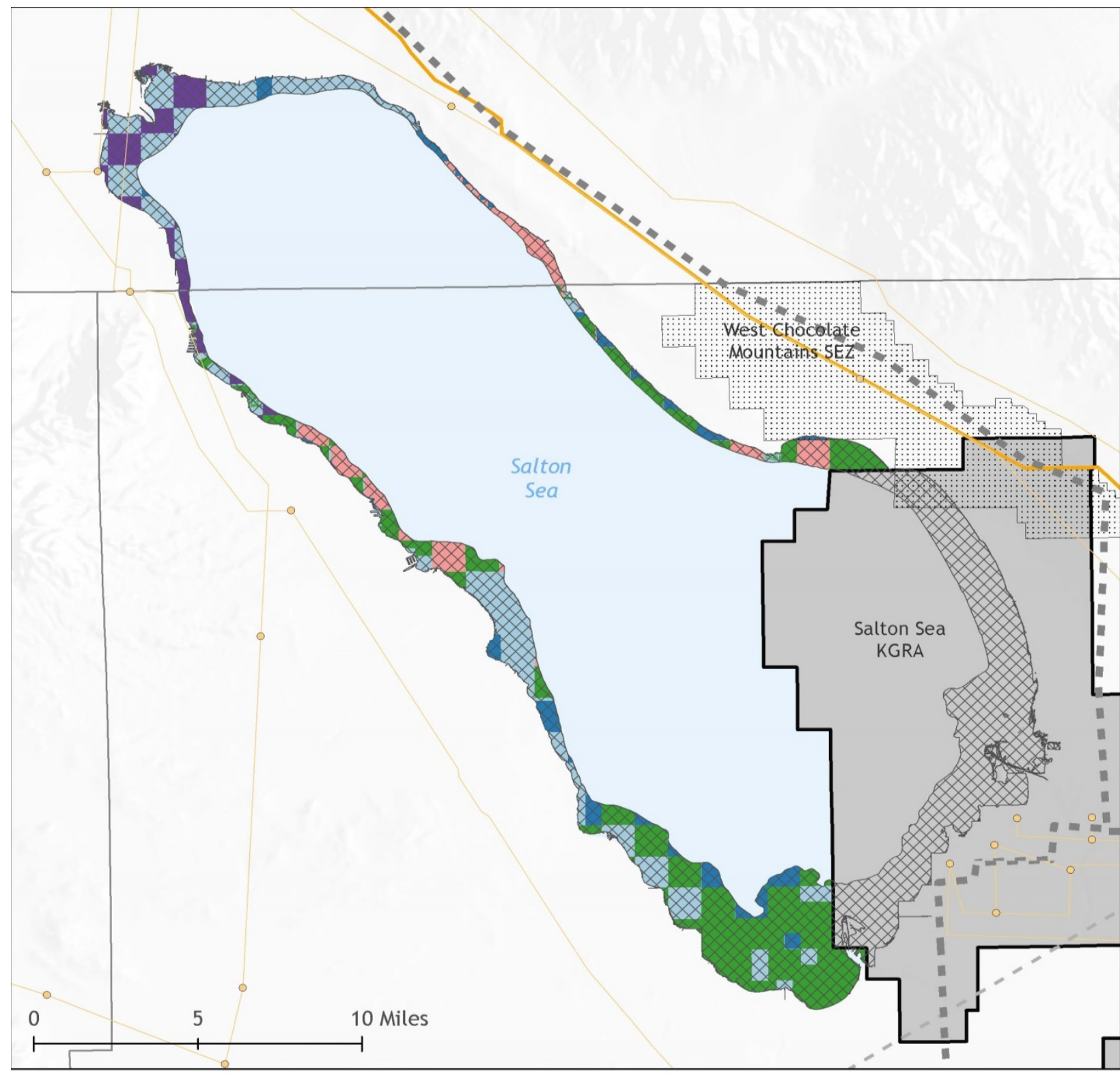

Developable Land by Ownership

IID
$\begin{aligned} & \text { BOR } \\ & \text { Private }\end{aligned}$
$\begin{aligned} & \text { Sribal } \\ & \text { Other (includes BLM, Solar Energy Zones } \\ & \text { FS, FWS, NPS, and State) }\end{aligned}$

Transmission Lines and Substations

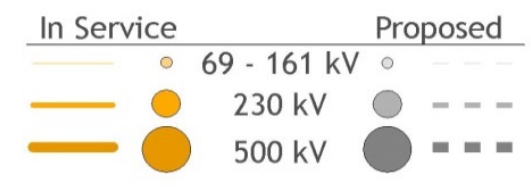

FS, FWS, NPS, and State)

Data Sources: National Renewable Energy Laboratory; Desert Renewable Energy Conservation Plan; Riverside County, CA; Imperial County, CA; Imperial Irrigation District; BLM; Ventyx Velocity Suite 2014.

Figure 16. Developable SGSP resource. 
The total potential SGSP resource on the Salton Sea playa is shown in Table 13. Although electricity production from salinity-gradient solar ponds has been technically proven, it has not been established as an economically viable power production technology to date. The low-grade heat $\left(70^{\circ} \mathrm{C}-90^{\circ} \mathrm{C}\right)$ produced by this technology may also be supplied to other processes, including: desalination, algae pond heating, food processing, and other industrial processes. An additional benefit of SGSP development on the playa is its potential to cover large areas of exposed playa while also generating an additional value stream (heat or electricity).

Potential constraints to development on the playa include transmission access on the exposed playa, as well as construction limitations such as construction mobilization and earth moving equipment access on playa soil. Although the developable small substation capacity for SGSPs is listed as 0 in Table 13, interconnection with smaller $69 \mathrm{kV}$ substations was not examined, and may be feasible for smaller projects. Given that SGSPs have not yet been developed within the region, $10 \mathrm{MW}$ to $100 \mathrm{MW}$ could be technically developable by 2030 , although this does not account for transmission access or economic viability, which are still uncertain. Assuming that the full 26,628 acres within 10 miles of $138 \mathrm{kV}$ to $230 \mathrm{kV}$ transmission was developed would result in a total developable capacity of $444 \mathrm{MW}$.

Table 13. Total Developable SGSP Capacity

\begin{tabular}{|l|l|l|l|l|}
\hline Technology & $\begin{array}{l}\text { Total } \\
\text { Capacity } \\
\text { Potential } \\
\text { (GW) }\end{array}$ & $\begin{array}{l}\text { Generation } \\
\text { Potential } \\
\text { (GWh/yr) }\end{array}$ & $\begin{array}{l}\text { Small } \\
\text { Sub. } \\
\text { Capacity } \\
\text { Potential } \\
\text { within 1 } \\
\text { mile }\end{array}$ & $\begin{array}{l}\text { Small Sub. } \\
\text { Generation } \\
\text { Potential } \\
\text { within 1 } \\
\text { mile }\end{array}$ \\
\hline $\begin{array}{l}\text { SGSP } \\
\text { (offshore) }\end{array}$ & $0.444^{*}$ & 3,500 & 0 & 0 \\
\hline
\end{tabular}

*This SGSP estimate was calculated using the following assumptions: 60 Acres/MW. Thermal efficiency of 20\%, and electric conversion rate of 5\% was assumed (Wang et al. 2010). Global horizontal insolation from the same Imperial, CA weather file that was employed for the PV and CSP cases yields an annual GHI $=2,106 \mathrm{kWh} / \mathrm{m} 2$. Small substations are defined as between $138 \mathrm{kV}$ and $230 \mathrm{kV}$.

Data Sources: National Renewable Energy Laboratory; Desert Renewable Energy Conservation Plan; Riverside County, CA; Imperial County, CA; Imperial Irrigation District; BLM. Ventyx Velocity Suite 2014.

\subsection{Algal Biofuels}

The United States currently imports approximately 50\% percent of its petroleum. The production of transportation fuels consumes two-thirds of that petroleum. The distribution of petroleum into transportation fuels has been changing in recent years with gasoline sales declining. Even so, approximately 134 billion gallons of gasoline were consumed in 2013, along with 59 billion gallons of diesel and 21 billion gallons of jet fuel. ${ }^{10}$ Though imports have been declining due to increased domestic production of petroleum, issues regarding dependence on foreign supply, as well as price volatility and growing concerns about global warming have led to an international movement toward renewable energy generation and carbon emission reduction.

\footnotetext{
${ }^{10} \mathrm{AEO} 2014$ is available on the EIA website, http://www.eia.gov/forecasts/aeo/.
} 
Due to the reduced water flow into the Salton Sea and the resulting evaporation and shrinkage of the sea, additional playa will be exposed as the shores recede. One of the technologies that could potentially be developed on this playa is algal biofuel biorefineries.

Since the beginning of the Aquatic Species Program in 1978, U.S. Department of Energy (DOE), projects and partnerships have made great strides in the effort to develop an algae-based biofuel substitute for diesel, jet fuel and gasoline. Algal biofuels may be a potential solution to some of the problems facing the Salton Sea for a number of reasons:

- Algal cultivation depends on large scale availability of flat, unproductive land to allow for establishment of cultivation facilities. The least capital intensive means to grow algae involves large scale open ponds (known as raceway ponds). These are typically very shallow (approximately $6.5 \mathrm{ft}$ ) to maximize the amount of light that can be absorbed by each photosynthetic algal cell with minimal self-shading. Even with shallow ponds, biomass concentrations in culture rarely rise above $1 \mathrm{~g} / \mathrm{L}$. In order to generate sufficient biomass for production of fuels and take advantage of economies of scale, a single algae farm will likely cover as much as 10,000 acres. Although many areas that could be used for algal cultivation have been identified in the United States, the deployment of large scale algal ponds in the Salton Sea playa could provide an additional benefit of covering the recently exposed soil, reducing the environmental challenges of potentially toxic dust to be spread by the wind.

- Algal cultivation depends on large volumes of water. Although some of that water can be recycled after the algae are harvested and concentrated, a significant amount will be lost due to evaporation. In a scenario involving freshwater cultivation, the evaporation would lead to competition for dwindling resources needed for drinking water, irrigation water, or industrial process water. However, algae do not need to grow in freshwater. Strains have been identified that can grow in brackish, saline, and even hypersaline water. The evaporating waters of the Salton Sea have been shown to be ideal (in terms of both salt content and nutrient availability) for algal cultivation, which has become a problem in its own right as natural algal bloom/death cycles lead to oxygen deprivation for fish and bad smells from rotting algal biomass (Barringer 2014). Use of Salton Sea water for controlled algal cultivation could reduce the amount of fresh water needed for cultivation and could remove nutrients from the water reducing the potential for algal blooms.

An algal biofuel project at this location may provide value to the Salton Sea area in several ways. This initial evaluation is an important first step in determining the value of the project, both to IID and to the biofuel community as it could serve as a prototype large scale operation. 


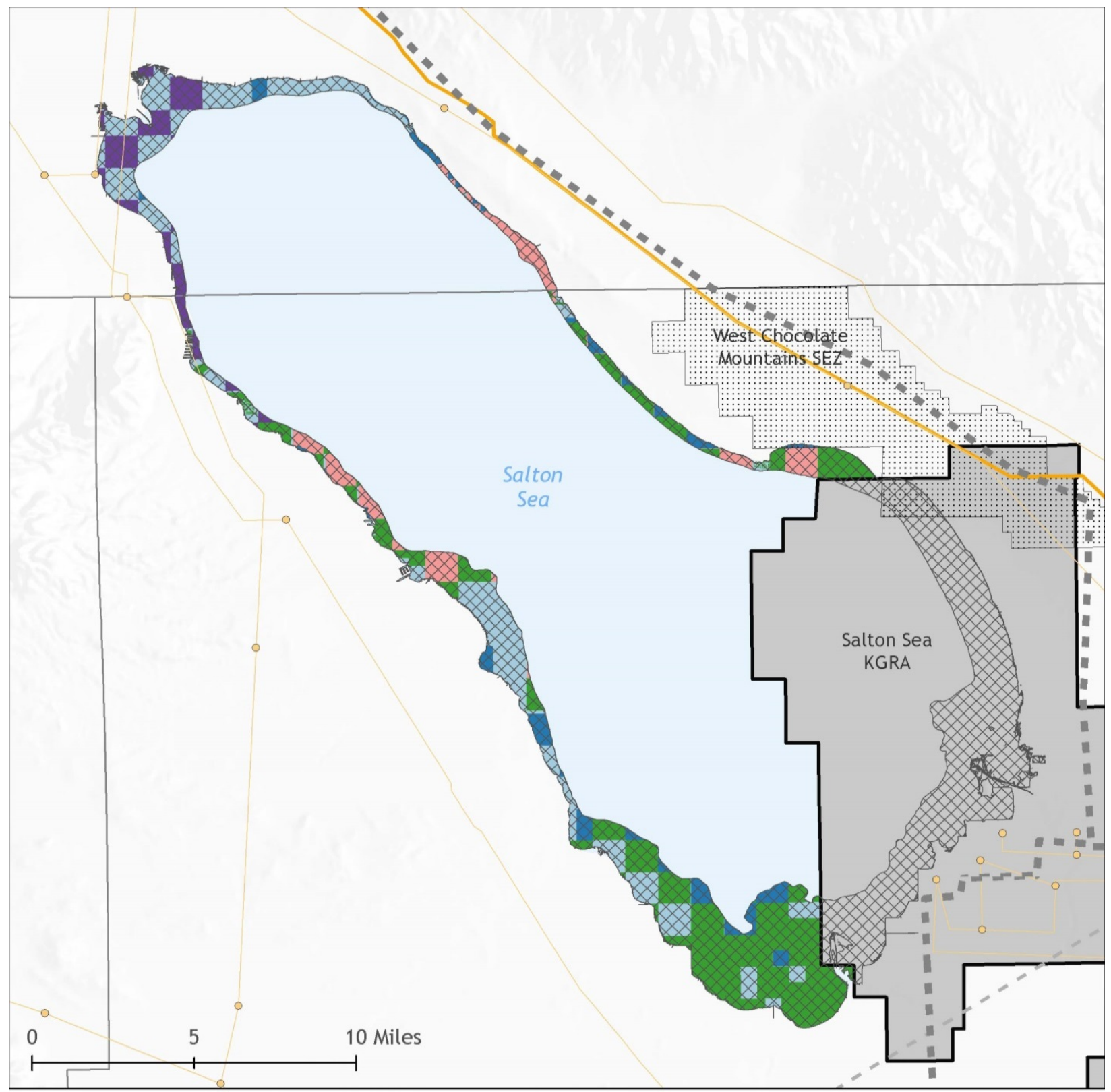

Developable Land by Ownership

\begin{tabular}{|c|c|}
\hline IID & Salton Sea Plan Area \\
\hline BOR & Solar Energy Zones \\
\hline Private & Salton Sea Playa \\
\hline 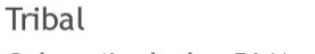 & Known Geothermal \\
\hline
\end{tabular}

Transmission Lines and Substations

FS, FWS, NPS, and State)

Data Sources: National Renewable Energy Laboratory; Desert Renewable Energy Conservation Plan; Riverside County, CA; Imperial County, CA; Imperial Irrigation District; BLM; Ventyx Velocity Suite 2014.

Figure 17. Developable algal pond resource. 
The total potential algal biofuels production capacity is listed in Table 14. The capacity figure is determined primarily by an algae power density of 1,200 gal/acre/year across the Salton Sea's developable areas. To put this into perspective, algal productivity values as high as 1,500 gal/acre/year have been reported by the DOE-sponsored Cornell Consortium for work carried out in hybrid photobioreactor/open pond systems located in Kona Hawaii. ${ }^{11}$ The study area was restricted to developable areas on the playa for several reasons. First, most forms of algal biofuel production are still pre-commercial and are not yet cost-competitive on a price per gallon basis. However, with the development of co-products, as well as an avoided-cost adder on exposed playa dust mitigation, algal biofuel production will likely become more financially attractive. Second, it appears that the exposed playa may be amenable to algae development, as several of the most widespread algae harvesting technologies in commercial operation (open unmixed and open raceway ponds) have high water requirements, cover large land areas, and are often sited in regions with high insolation. The developable land within the Salton Sea KGRA was also excluded, as development of geothermal projects on this land would likely take priority. However, due to the small footprint of geothermal plants, algal biofuel development within the KGRA acreage may be possible after full geothermal development has occurred. Since the Salton Sea's future evaporation rates are still uncertain, the ultimate area of exposed playa will vary. Potential constraints to development on the playa include transmission access on the exposed playa, as well as construction limitations such mobilization and earth moving equipment access on playa soil. ${ }^{12}$ An area for future study would be an analysis of the developable potential of algae cultivation for nutrition or cosmetic supplements. Using $13 \mathrm{~g} / \mathrm{m}^{2} /$ day, a conservative figure for algal biomass productivity, ${ }^{13}$ it is possible to estimate the annual production capacity for algal biomass on the developable playa (Table 14).

Table 14. Developable Playa and Potential Algal Production Capacity by 2030

\begin{tabular}{|l|c|c|}
\hline Technology & Acreage & $\begin{array}{l}\text { Algal Production Capacity } \\
\text { (gal/year) }\end{array}$ \\
\hline $\begin{array}{l}\text { Algal Biofuels } \\
\text { (offshore) }\end{array}$ & $32,821.4$ & $39,385,674.2$ \\
\hline $\begin{array}{l}\text { Algal Food } \\
\text { and Feed } \\
\text { (Offshore) }\end{array}$ & $32,821.4$ & 600,000 tons/year \\
\hline
\end{tabular}

Sources: ANL; NREL; PNNL. (June 2012)

\section{Revenue Opportunities}

Additional avenues for revenue development from algae exist, such as the development of fuels other than ethanol and co-products (protein and fertilizer). In addition, there is a potential for several synergies through co-development of geothermal resources, as the availability of geothermal heat and brine could provide low cost energy inputs for improved cultivation of algae in cool weather months. Although these co-product options are explored, they have not been

\footnotetext{
11 "Five Energy Department Accomplishments in Algal Biofuels," accessed 4/29/2015, http://energy.gov/eere/articles/five-energy-departmentaccomplishments-algal-biofuels.

${ }^{12} \mathrm{http}: / /$ www. syntheticgenomics.com/media/press/051613.html, accessed 6/5/15.

${ }^{13}$ This figure is discussed in more detail in "Renewable Diesel from Algal Lipids: An Integrated Baseline for Cost, Emissions, and Resource

Potential from a Harmonized Model," http://www.nrel.gov/docs/fy12osti/55431.pdf.
} 
analyzed in detail for Salton Sea restoration revenue potential, due to their early or precommercial nature.

- Most algal biofuel companies are exploring multiple fuel types as viable options, with only one company known to be involved almost solely in the production of ethanol (Algenol). Several other companies are targeting biodiesel or "drop-in" fuels such as renewable diesel and jet fuel, but these are not yet commercially available.

- Some current estimates about $\mathrm{CO} 2$ requirements, production cost for photobioreactors (Algenol's production cost) and open pond systems follow:

- $\mathrm{CO} 2$ requirements are more likely around $25-30 \mathrm{~kg} \mathrm{CO} 2 / \mathrm{gal}$, based on approximately $2.5 \mathrm{~kg} \mathrm{CO} 2 / \mathrm{kg}$ biomass.

- $\$ 50 /$ barrel of fuel is currently being reported by Algenol, which is also claiming production rates of $8,000 \mathrm{gal} / \mathrm{acre} / \mathrm{year}$.

- The most recent published estimate for algal biofuel production is approximately $\$ 14 /$ gal, based on algal biomass production costs of $\sim \$ 1000 /$ ton and ALU (algal lipid extraction and upgrading) with ethanol as a co-product based on fermentation of the algal sugars released in the extraction process (Davis et al 2012).

- Concerning future price declines, a path to $\$ 3 /$ gallon has been proposed in the DOE multi-year program plan. This primarily involves improvements in growth rates, as well as cultivation and harvesting processes. ${ }^{14}$

- One method for improving the economic scenario is through the production and marketing of value-added co-products. These products create additional revenue to help offset production costs. As the goals of the IID are to generate revenue from renewable energy products, coproducts could play an important role. As noted above, the NREL fractionation process can provide lipid, carbohydrate, and protein streams that can serve as feedstocks for a variety of coproducts with sales prices significantly higher than those of fuels.

\section{Algae Oil Production and Wastewater Treatment}

It is very likely that a significant $R \& D$ effort will be needed before algae oil production processes become sufficiently cost effective to compete with fossil fuels (even with greenhouse gas reduction subsidies). Although this does not detract from the long-term potential and promise, it does raise the issue of what type of co-products could be integrated into an algal oil production process to make it more attractive in the near-term. The first such co-product is water purification, or more specifically, municipal wastewater treatment.

Algae cultivation in municipal wastewater treatment ponds helps remove nitrogen and phosphorous from effluent water, in addition to concentrating heavy metals for easier removal. Potential advantages of utilizing these treatment ponds for cultivation of algae are well

14 “Bioenergy Technologies Office Multi-Year Program Plan”, March 2015, http://www.energy.gov/sites/prod/files/2015/04/f22/mypp beto march2015.pdf. 
documented and could conceivably be used to treat Salton Sea water to allow it to be used for other purposes. A TurfScrubber type system could be deployed in the Salton Sea itself in addition to open pond deployment on the playa and the combined biomass could be used for conversion to products.

\section{Dust Mitigation}

As more and more playa is uncovered due to evaporation of the Salton Sea, concerns raised from atmospheric pollution from dust and accompanying heavy metals and other toxins arise for the surrounding area. Large scale deployment of open ponds or photobioreactors such as those developed by Solix could help mitigate this problem by covering large areas of playa.

\section{Geothermal Energy Capture}

Although algae have been found that can thrive in environments ranging from freezing to above boiling temperatures, it typically grows fastest at moderate temperatures. As temperatures drop below an optimal point (at night or during cooler months), growth slows down and can even stop. Although it has been shown that productivity will resume when a pond has thawed after being frozen solid, it is much more effective to maintain temperatures near the optimum. With an abundance of geothermal energy available in the Salton Sea area, it could be possible to prevent freezing, extend the growing season and maintain higher growth rates overall by using the geothermal energy to keep the cultivation medium near the growth temperature optimum.

\section{Fertilizer}

Fertilizer is a reasonably large volume co-product, assuming that the biomass doesn't contain substantial amounts of contaminants, such as viruses from wastewater or heavy metals from the $\mathrm{CO} 2$ source or from the water. The latter could be a problem with Salton Sea water. Accelergy is developing a fertilizer process based on the harvesting of nitrogen fixing cyanobacteria and using the biomass to amend especially degraded soils from mining operations. The living cyanobacteria can continue to fix nitrogen in the soil and thus continue to enrich the soil for an extended period. It is also possible to apply dead algal cells to soils simply to take advantage of the inherent nutrients present in the biomass.

\section{Food and Feed}

Human nutritional supplements and specialty animal feed are possible standalone products or coproducts from algal oil production. Conventional animal feeds (e.g., soy protein or dried distiller's grains) have too low a value (\$/ton) to allow for a sufficient co-product credit, after considering the cost of production (which would include drying of the feed). Algal biomass may need to be valued at a minimum of $\$ 500 /$ ton to overcome the costs of drying. This is much higher than dried distiller's grains, and this target price could only be achieved if the quality could match such feed products as fish meal.

Specialty animal feeds, which have a higher value than conventional feeds but a lower one than human foods, have a large potential market. After extraction of the oil, the remaining biomass produced could contain as much as approximately $50 \%$ protein and other nutrients, most importantly carotenoids. There is a large market for animal feeds containing carotenoids, in particular lutein for chicken feeds, with zeaxanthin and beta-carotene also of interest. These markets are estimated at several million tons per year, nationwide. Algal biomass has a $0.5 \%$ 
lutein concentration allowing for an added value for the algal biomass of about $\$ 1,000 /$ ton. Currently, these markets are supplied by carotenoids derived from marigold plants.

Feeding studies with algal biomass involving fish, shellfish, cattle, pigs and chickens have been carried out, with variable results. Biomass may support growth of one species but not another. In some cases, algal biomass can be used as a supplement for more traditional feed materials.

Similarly, dried whole algal biomass and some of the components of algal biomass including omega-3 fatty acids and carotenoids are used as human food supplements of nutraceuticals. Specific algae including the cyanobacterium Arthrospira platensis (commonly known as Spirulina) and the eukaryotic alga Chlorella can be found in healthfood stores in powder or tablet form or as an ingredient in prepared foods and drinks.

A potential drawback of using Salton Sea biomass to produce food or feed could be the accumulation of various dissolved compounds in the water into the algal biomass. As the Salton Sea has evaporated, the concentration of these compounds is likely to have increased. One specific compound to consider is selenium, which is an essential nutrient at low concentrations with a minimum recommended daily human intake of $70 \mathrm{ug} .{ }^{15}$ Higher doses can lead to selenosis or even death with a median lethal dose of $7 \mathrm{mg} / \mathrm{kg}$ to $7,000 \mathrm{mg} / \mathrm{kg}$ depending on the chemical form of the selenium. A report from the Dept. of Environmental Sciences at UC-Riverside indicates that the selenium concentration in the Salton Sea is approximately $1 \mathrm{ug} / \mathrm{L}$. Assuming that algae cultivated in Salton Sea water could accumulate all of the Se present, the concentration in biomass would be about $1 \mathrm{ug} / \mathrm{g}$ biomass. Algal nutritional supplements typically contain $1 \mathrm{~g}$ dried biomass per tablet or $1 \mathrm{~g}$ per serving as a formulated product. The selenium dose from a single serving would be far below the recommended daily intake and more than an order of magnitude lower than a typical serving of such foods as tuna, steak, macaroni, or cottage cheese. If components of algal biomass such as omega-3 fatty acids or carotenoids were the desired product, it is likely that the selenium would be lost in the purification process and it would be unlikely to provide much of a problem.

Additional analysis would need to be carried out to determine the concentration of heavy metals such as lead, cadmium, or mercury. These metals could also be accumulated in the algal biomass and, unlike Se, could pose health risks for both humans and animals even at low doses.

\section{Energy Recovery}

Residual biomass can be anaerobically digested using proven technologies to create a biogas that typically contains $60 \%$ methane and $40 \% \mathrm{CO} 2$ by volume. This gas may be used to offset natural gas to power the algal production facility with additional power used to feed the grid.

Glycerol, a byproduct of the biodiesel production process, may also be recycled to create energy. It is currently being evaluated by a number of groups as a feedstock for fermentation to produce ethanol or other biofuels.

\footnotetext{
${ }^{15}$ http://ods.od.nih.gov/factsheets/Selenium-HealthProfessional/
} 


\section{Nutrient Recovery}

The liquid effluent from the anaerobic digestion process contains soluble nitrogen, which can be recovered in the form of ammonia for recycling in subsequent cultivation. It will also contain phosphorous, potassium and other inorganic micronutrients which can be recycled. Although nutrients from Salton Sea water have already been discussed as a valuable input, recycled effluent from anaerobic digestion can be used to supplement this.

\section{Others}

Many other higher value co-products (higher than the value of fuels) have been proposed for microalgal biofuels production, including pharmaceuticals and bioplastics. However, these products typically do not have large enough market volumes to help defray the high cost of algal biomass production and allow for co-production of significant levels of algal oil.

\section{Additional Technical and Economic Potential}

In addition to the technical potential of renewable energy technologies to provide electricity, the potential for desalination and geothermal brine mineral recovery was also examined.

Applications of both technologies have already been technically demonstrated at the Salton Sea, however, their economic viability and scalability is still uncertain.

\subsection{Desalination and Renewable Energy}

Desalination is the process of removing dissolved salts from an impaired or low-quality water source to produce water with sufficiently low TDS's to be used for potable water or some other beneficial use. In the broadest case, the desalination process requires three primary components: 1) a source of impaired water for treatment, 2) a means of disposing of the concentrated brine or dewatered salts, and 3) energy to drive the desalination process. This section describes the options available for the use of renewable energy (solar electric, solar thermal, or geothermal) to power desalination processes in the Salton Sea region. Prior studies have concluded that desalination is a potential path for Salton Sea restoration. While one could utilize renewableelectric-powered reverse osmosis technology, the ability to use thermal-desalination technologies with energy from low-grade geothermal resources and/or solar ponds is a particularly attractive option for the region.

\subsubsection{Regulatory and Environmental Hurdles}

Some of the local agencies which will be required to perform a review include: the Colorado River Regional Water Quality Control Board, the Imperial County Planning \& Development Services Office, and potentially the Imperial County Public Works Department.

The primary regulatory framework at the state level for desalination facilities will likely be the State Water Resources Control Board's proposed "Amendment to the Water Quality Control Plan for Ocean Waters to Address Desalination Facilities." These regulations primarily focus on coastal desalination facilities, but some aspects (intake screen slot size, brine disposal) could apply to proposed projects at the Salton Sea as well. Notably, since Salton Sea desalination is inland, all brine concentrate must be handled as part of the desalination process. However, rather than simply disposing of this brine concentrate, it may be possible to apply it to a beneficial use. The brine could either be further concentrated and evaporated to dryness, producing a potential salt product, or alternatively, piped into a salinity gradient solar pond. 
Additional state regulations include the Porter-Cologne Water Quality Control Act, which vests authority in the State Water Board to control point-source discharges and the California Environmental Quality Act, which requires state and local agencies to minimize environmental impacts through environmental permitting processes.

Some possible environmental concerns include the creation of point-source pollution, brine contamination of groundwater, and brine runoff. Of additional environmental concern is the availability of Salton Sea surface water for desalination efforts, as desalination technologies require thousands of cubic meters of water each day to operate. These potential environmental concerns will need to be evaluated in relation to the proposed benefits of desalination.

\subsubsection{Role of Desalination in Restoration Efforts}

Desalination from renewable energy could provide a significant potential benefit for Salton Sea restoration efforts by feeding desalinated water back into the Sea and addressing the increasing salinity problem directly. Although this method is technically feasible, returning fresh water to the Sea at zero or near-zero cost requires an alternative source of revenue for the process, such as salt sales.

However, a strategy based on revenue from salt sales assumes that there is a developer with sufficient capital and technical expertise to execute on this type of integrated project, and several assumptions included in this high-level estimate may not materialize, such as the availability of a sufficient market price for salt, or an acceptable performance of the system at scale.

\subsubsection{Desalination Technologies}

Major types of commercial desalination technologies are listed Table 15. A detailed explanation of each of these technologies is beyond the scope of this report; for additional information, refer to other sources such as a 2009 report published by the Colorado School of Mines (CSM 2009) or an NREL-authored article in Renewable and Sustainable Energy Reviews (Al-Karaghouli and Kazmerski 2013). Desalination is a growing market worldwide, with rapid growth in the worldwide deployment of desalination technologies since the early 2000's, as shown in Figure 18. Early-generation technologies were primarily thermal, but membrane-based approaches have surpassed deployment of thermal desalination in recent years. 
Table 15. Leading Desalination Technologies

\begin{tabular}{|c|c|c|c|}
\hline $\begin{array}{l}\text { Leading Desalination } \\
\text { Technologies }\end{array}$ & $\begin{array}{l}\text { Electric } \\
\text { Energy } \\
\text { Required }\end{array}$ & $\begin{array}{l}\text { Thermal } \\
\text { Energy } \\
\text { Required }\end{array}$ & Comments \\
\hline Electrodialysis & $\checkmark$ & & \\
\hline $\begin{array}{l}\text { Reverse osmosis } \\
\text { Brackish water reverse osmosis } \\
\text { Seawater reverse osmosis }\end{array}$ & $\checkmark$ & & $\begin{array}{l}\mathrm{RO} \text { is the most common desal } \\
\text { technology. Brackish water has lower } \\
\text { salinity than seawater. }\end{array}$ \\
\hline Membrane distillation & $\checkmark$ & $\checkmark$ & \\
\hline Thermal vapor compression & $\checkmark$ & $\checkmark$ & \\
\hline Mechanical vapor compression & $\checkmark$ & & $\begin{array}{l}\text { Similar to TVC, but mechanical } \\
\text { compression provides thermal input }\end{array}$ \\
\hline Multi-stage Flash & $\checkmark$ & $\checkmark$ & $\begin{array}{l}\text { Extensive use in Middle East; robust; } \\
\text { large energy demand. Normally } \\
\text { employs steam for thermal input. }\end{array}$ \\
\hline Multi-Effect Distillation & $\checkmark$ & $\checkmark$ & $\begin{array}{l}\text { More energy efficient than MSF. } \\
\text { Normally employs steam for thermal } \\
\text { input. }\end{array}$ \\
\hline
\end{tabular}

Source: CSM 2009
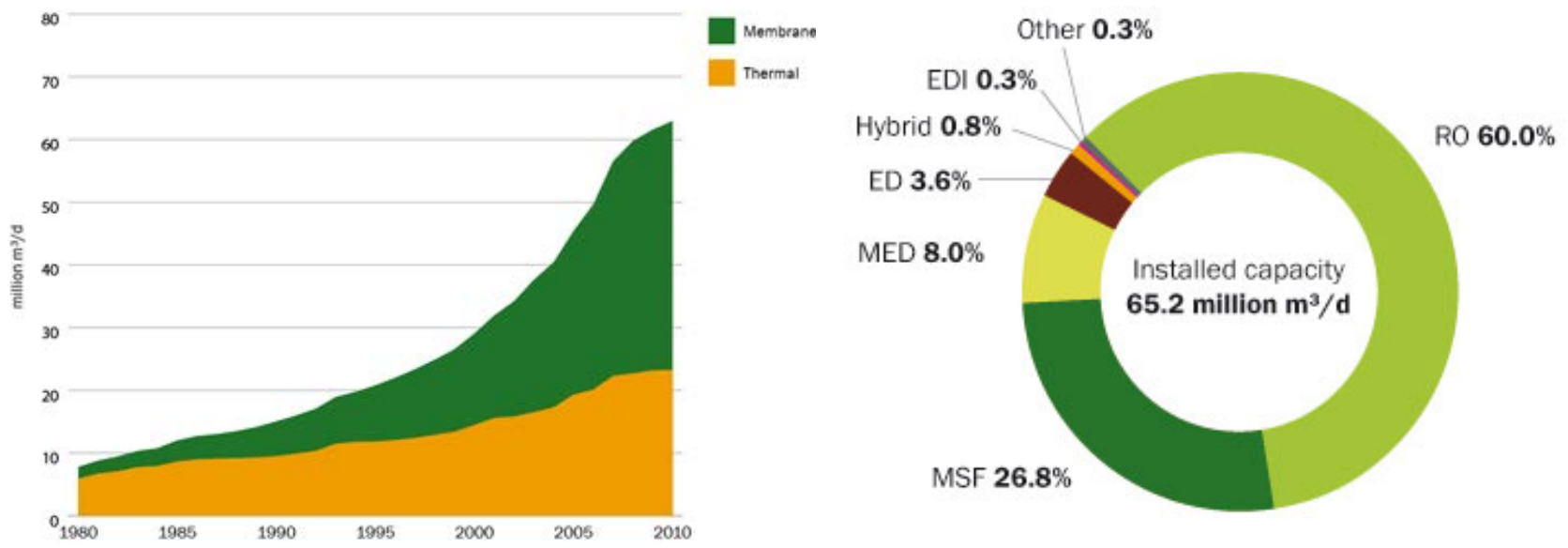

Figure 18. Desalination technology deployment worldwide. Images from Desaldata.com

Note: The growth of membrane-based technologies has exceeded that for thermal-based technologies. Reverse osmosis (RO) capacity now exceeds that for thermal systems such as multi-stage flash (MSF) and multi-effect distillation (MED).

Factors affecting the cost of water desalination include: intake water quality, plant capital cost, energy cost, labor and maintenance cost, concentrate disposal cost, and financing interest rate. Water desalination is an energy-intensive process, and energy costs typically account for about half of the total cost of produced water (Al-Karaghouli and Kazmerski 2013). Understanding the energy demands of different desalination technologies is essential for any discussion of combining renewable energy sources with water desalination. In particular, it is important to distinguish between electrical and thermal energy demands required for the different desalination processes. All technologies require electric power for pumping, sensors, and process controls, and in the case of reverse osmosis processes, electricity for pumping is the primary energy requirement. Reverse osmosis, the most commonly deployed and lowest-cost desalination technology, utilizes osmotic pressure differentials to drive separation of fresh water from the 
concentrated brines. Other technologies, such as multi-stage flash (MSF) and multi-effect distillation (MED), use mainly thermal energy for the desalination process. These technologies can utilize low-grade thermal energy from solar or geothermal resources.

\subsubsection{Existing Desalination Technologies in the Salton Sea}

Currently, there appears to be one desalination company, Sephton Water Technology, Inc. operating by the Salton Sea. This company uses a vertical tube evaporation process that is a form of the MED technology discussed above. Since 2005, Sephton has operated several pilot-scale projects on the edge of Salton Sea, with a combined capacity of approximately 25,000 gal/day. These plants currently rely on low temperature steam provided by adjacent geothermal plants, but could also potentially utilize low-grade heat from salinity gradient solar ponds in the future.

\subsubsection{Energy Demand by Desalination Technologies}

Integration of desalination and renewable energy has been the topic of several reviews and programs. Promotion of Renewable Energy for Water Production through Desalination (PRODES) was a European program that produced a roadmap of renewable energy/desalination and documented over 130 demonstration and operating projects worldwide. ${ }^{16}$ Al-Karaghouli and Kazmerski explored the potential of renewable energy and desalination and tabulated the energy demand for the primary desalination technologies (Table 16). Representative costs for electric energy and thermal energy are shown to provide context on the energy cost for desalinating water. For comparison, the total cost per cubic meter ranges from about $\$ 0.5 / \mathrm{m}^{3}$ to $\$ 2 / \mathrm{m}^{3}$ depending on the technology and plant capacity. Thus, in general terms, energy cost amounts to about half the total cost of water desalination.

Table 16. Typical Energy Consumption by Primary Desalination Technologies

\begin{tabular}{|c|c|c|c|c|c|c|c|}
\hline Property & MSF & MED & TVC & MVC & SWRO & BWRO & ED \\
\hline Typical capacity (1000-m³/day) & $50-70$ & $5-15$ & $10-30$ & $0.1-3$ & $<130$ & $<100$ & $<145$ \\
\hline Electric energy use $\left(\mathrm{kWh} / \mathrm{m}^{3}\right)$ & $2.5-5$ & $2-2.5$ & 1.6-1.8 & $7-12$ & $4-6$ & $1.5-2.5$ & $2.6-5.5$ \\
\hline $\begin{array}{l}\text { approx. cost }\left(\$ / \mathrm{m}^{3}\right) \text { at } \\
\$ 0.1 / \mathrm{kWh}\end{array}$ & 0.3 & 0.2 & 0.2 & 1 & 0.5 & 0.2 & 0.4 \\
\hline Thermal energy use $\left(\mathrm{MJ} / \mathrm{m}^{3}\right)$ & $190-280$ & $145-230$ & 230 & - & - & - & - \\
\hline $\begin{array}{l}\text { approx. cost }\left(\$ / \mathrm{m}^{3}\right) \text { at } \\
\$ 0.005 / \mathrm{MJ}^{*}\end{array}$ & 1.1 & 0.9 & 1.2 & - & - & - & - \\
\hline $\begin{array}{l}\text { Typical minimum temp. } \\
\text { requirement }\end{array}$ & $90^{\circ} \mathrm{C}$ & $70^{\circ} \mathrm{C}$ & $70^{\circ} \mathrm{C}$ & - & - & - & - \\
\hline
\end{tabular}

The type of energy required is a pivotal consideration when considering renewable-energy powered desalination. Wind or Solar PV could be used to power an all-electric desalination process, although accommodation would have to be made for fluctuation in the resource. From a technical perspective, batteries can be added, but this is unlikely to be economically attractive.

The more interesting case for renewable energy desalination in the Salton Sea region is the potential to use geothermal or solar thermal energy with a thermal-desalination process. The benefit of this approach is that the process can be designed to run $24 / 7$ for smoother operation of

\footnotetext{
${ }^{16}$ Roadmap for the development of desalination powered by renewable energy, http://www.prodes-project.org.
} 
the desalination treatment process. In the case of geothermal, such high availability is routine. For solar thermal, storage of the solar heat transfer fluid could be incorporated to separate solar collection from energy use and ensure a much higher availability.

The first question when considering thermal desalination options is what temperature is required to drive the process. Most thermal-desalination technologies require an input temperature in the range from about $60^{\circ} \mathrm{C}$ to $110^{\circ} \mathrm{C}$. The major commercial technologies, MSF and MED, are designed to utilize low-pressure steam at around $100^{\circ} \mathrm{C}$ or higher. While this may be available via a geothermal or solar thermal source (e.g., exhaust steam from a renewable-powered steam turbine), a lower cost and more widely distributed resource is hot water in the form of lowtemperature geothermal brine or solar thermal collectors such as flat plate collectors or solar ponds. In the case of geothermal energy, one could utilize low-grade geothermal heat directly, or integrate the desalination process with waste heat from a geothermal power plant. Tapping into low-grade heat at a geothermal plant obviates the need for new geothermal source wells; however, one must account for possible negative impacts on the operation of the geothermal power plant and maintenance of the geothermal reservoir temperature through reinjection. With either renewable resource, the direct use of thermal energy (i.e., without conversion losses to make electric power) can be very efficient.

MSF and MED are the most common thermal-desalination technologies worldwide. Smallerscale, emerging thermal desalination technologies include membrane distillation and humidification. These systems have important advantages that enable coupling with waste heat or renewable-energy-driven systems such as geothermal or solar energy. Some advantages include the ability to operate at lower temperatures $\left(50^{\circ} \mathrm{C}\right.$ to $\left.80^{\circ} \mathrm{C}\right)$, at higher brine concentrations, and at lower pressures than other thermal-driven or pressure driven systems. Other advantages are the ability of the system to operate intermittently without causing damage to the system and minimal chemicals required for pre-treatment of the feed water (Camacho et al. 2013).

\subsubsection{Source Water Composition and effect on Desalination Technology Selection}

Desalination technologies respond differently to changes in TDS. TDS is the amount of dissolved inorganic and organic constituents in water and is typically reported in $\mathrm{mg} / \mathrm{L}$. In seawater and many other brines the largest contribution to TDS is from sodium chloride; TDS is often referred to as salinity. Osmosis-based desalination processes are sensitive to the TDS level of the source water, while thermal treatment processes are relatively insensitive to source water quality. A specific example of this sensitivity is a comparison of brackish water reverse osmosis (BWRO) and seawater reverse osmosis (SWRO). As shown in Table 16, the energy consumption (and overall cost) of BWRO is less than SWRO due to the lower salinity of brackish water. Given the relatively high salinity of potential source waters in the region, thermal-desalination technologies will have a relative advantage over reverse osmosis.

Impaired source water options in the Imperial Valley include the Salton Sea itself, brackish groundwater, and geothermal brines. Various Imperial Valley entities have investigated desalination as an option for providing irrigation water because there is a significant amount of impaired groundwater available; however, these studies did not focus on renewable energy use to complement the process. A summary of typical source water TDS levels for the Imperial Valley is provided in Table 17. 
Table 17. Total Dissolved Solids of Potential Source Water for Desalination for the Imperial Valley

\begin{tabular}{|c|c|c|}
\hline Impaired source water & $\begin{array}{c}\text { Source water TDS } \\
\text { criterion }\end{array}$ & $\begin{array}{l}\text { Source water } \\
\text { TDS (mg/L) }\end{array}$ \\
\hline \multirow[b]{2}{*}{ groundwater } & $25^{\text {th }}$ percentile & 1,500 \\
\hline & $75^{\text {th }}$ percentile & 390,000 \\
\hline \multirow{2}{*}{ geothermal brine } & $25^{\text {th }}$ percentile & 45,400 \\
\hline & $75^{\text {th }}$ percentile & 260,000 \\
\hline surface water (Salton Sea) & Mean & 50,000 \\
\hline
\end{tabular}

Groundwater. Data for Imperial and Riverside Counties, California accessed from the 2014 United States Geological Survey show the groundwater quality varies widely with TDS concentration ranging from $300 \mathrm{mg} / \mathrm{L}$ to over $100,000 \mathrm{mg} / \mathrm{L}$. In general, the groundwater is sodium chloride dominated. The dataset contains information on over 100 groundwater wells.

Geothermal brine. A data file from the Association of American State Geologists node on the National Geothermal Data System provides geothermal data for the Salton Trough. This dataset consists of roughly 40 wells, with TDS ranging from 1,400 to 385,000 mg/L. The geothermal brines of the Salton Trough are mostly sodium chloride dominated.

Surface water. A report from the U.S. Bureau of Reclamation provided the surface water quality data for the Salton Sea. ${ }^{17}$ This report compares the water quality of the Salton Sea to the rivers that feed it, giving one example of the water quality for each. TDS of the Salton Sea given in the report is $44,000 \mathrm{mg} / \mathrm{L}$, while the reported value in 2014 is closer to $55,000 \mathrm{mg} / \mathrm{L}$. The dominant ion pair in the sea is sodium chloride. In addition, based on discussions with local operators, there appear to be issues with scaling, due to the presence of magnesium and calcium, that require additional measures to ensure smooth system operations.

Based on the relatively high TDS of available source water in the Salton Sea region, thermal desalination technologies are an attractive option.

\subsubsection{Solar Ponds and Desalination}

The combination of requirements at play in the Salton Sea region lead to a unique set of conditions for the use of geothermal energy, solar ponds, and desalination.

${ }^{17}$ U.S. Department of Interior Bureau of Reclamation, http://www.usbr.gov/lc/region/saltnsea/FinalSummaryRpt.pdf, accessed 6/10/2015. 
Table 18. Use of Geothermal Energy, Solar Ponds, and Desalination

\begin{tabular}{|c|c|c|}
\hline Inputs & Source(s) & Use \\
\hline Hot geo-brine & geothermal production well & thermal input to geothermal power plant \\
\hline Solar thermal energy & Sun & thermal input to solar pond \\
\hline Impaired water & $\begin{array}{l}\text { Salton Sea; groundwater; solar } \\
\text { pond }\end{array}$ & source water for desalination \\
\hline \multicolumn{3}{|l|}{ Outputs } \\
\hline Electric power & geothermal plant & $\begin{array}{l}\text { onsite pumps, fans, and controls; sale to } \\
\text { grid }\end{array}$ \\
\hline Fresh water & desalination plant & solar pond makeup; sale to local users \\
\hline Cooled brine & geothermal plant & reinjection well; solar pond \\
\hline Reject water & desalination plant & reinjection well; solar pond \\
\hline
\end{tabular}

In regions of good solar resource such as the Imperial Valley, solar ponds can deliver hot water at temperatures of approximately $70^{\circ} \mathrm{C}$ on an almost continuous basis (See Section 4 for additional detail). However, these ponds require extensive land area, high-salinity brine, and occasional make-up fresh water. In this instance, a large facility footprint may be a desirable feature as the solar ponds can reduce airborne dust from the exposed Salton Sea playa. Furthermore, the initial charge of high-salinity brine for solar ponds can be generated by tapping into the geothermal brines or from reject water off desalination processes. A conceptual schematic of the interconnection of the geothermal, solar pond, and desalination processes is depicted in Figure 19.

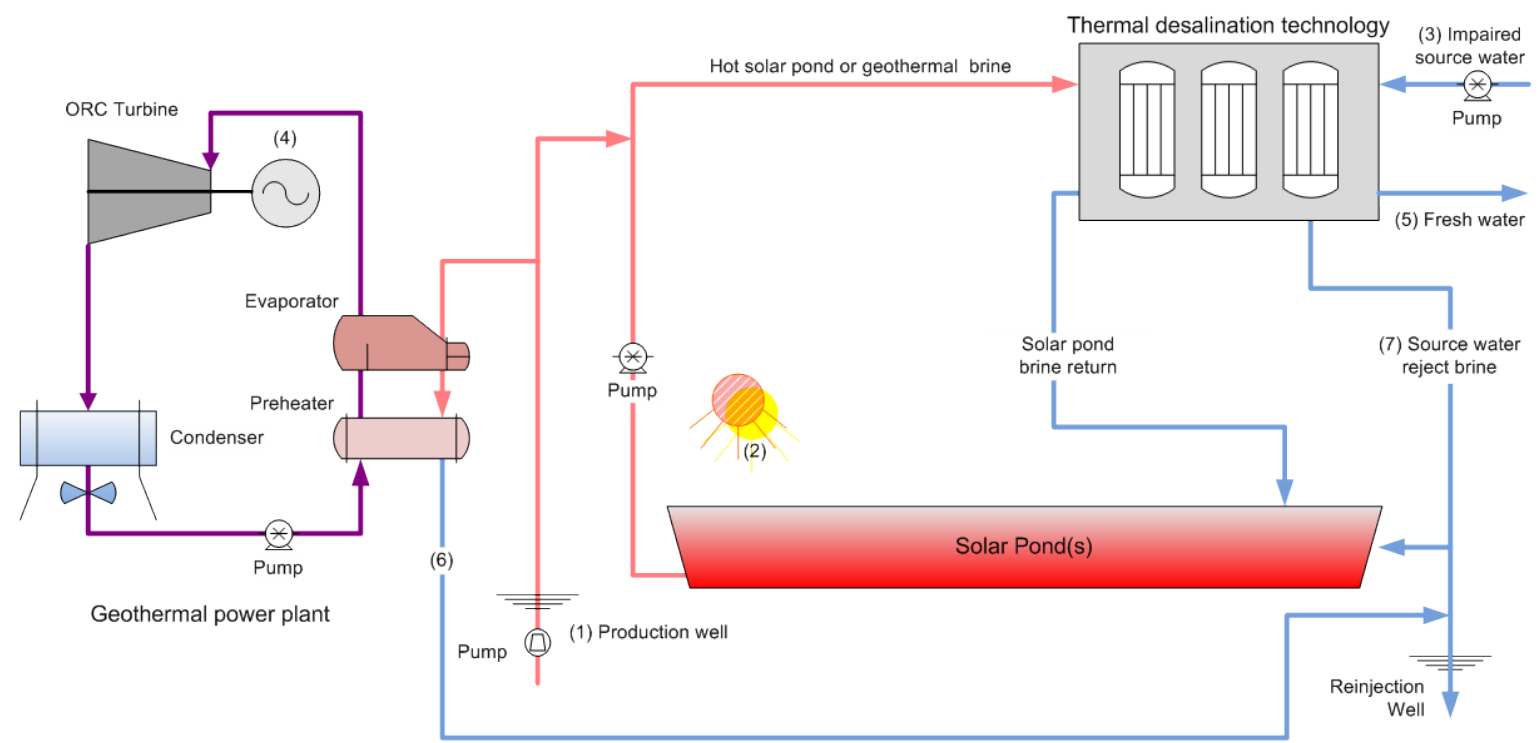

Figure 19. Thermal desalination process interfaced with a solar pond and a geothermal power plant. Illustration by NREL

The interconnectivity between the solar pond, geothermal plant, and desalination plant allows for a great deal of flexibility and synergy in the system operation. The solar pond can tap into highsalinity geo-brine or reject brine from the desalination plant for its initial charge of brine, thus avoiding the salt cost that is normally a substantial fraction of the cost for constructing a solar pond. Once the pond reaches full temperature, either solar or geothermal energy can be used to 
drive the thermal desalination process. If the geothermal resource is hot enough, electric power can be produced, although this is not essential for the geothermal/solar pond/desalination system.

The thermal desalination technology can be selected from several options that are capable of operating at temperatures of $90^{\circ} \mathrm{C}$ or less. Consultation with technology vendors and preliminary design work would be required to estimate overall system cost.

\subsection{Geothermal Fluid Mineral Recovery}

Geothermal fluids are potentially significant sources of valuable minerals and metals. With increasing worldwide demand for technology, and in particular, the increased consumer demand for clean energy technologies and electric vehicles, significant attention in both the United States and abroad has been turned to identifying "critical raw materials" and their market dynamics. The DOE's 2011 Strategic Materials Plan identified 16 minerals critical to clean energy technologies (Figure 20), and the U.S. Department of Defense issued a separate 2013 report which identified shortfalls in 23 strategic materials where supply will be outstripped by demand in the near future (Figure 21) (U.S. DOD 2013). The European Commission has also issued a similar list of 14 critical materials on which they are almost wholly dependent. ${ }^{18}$ More generally, the United States relies entirely on foreign imports for 17 mineral commodities and relies on imports for $>50 \%$ of more than 24 other minerals (as of 2013). ${ }^{19}$

\footnotetext{
${ }^{18} \mathrm{http} / / /$ www.ukerc.ac.uk/publications/materials-availability-for-low-carbon-technologies.html

${ }^{19} \mathrm{http} / / /$ www.usgs.gov/blogs/features/usgs_top_story/going-critical-being-strategic-with-our-mineral-resources/
} 


\section{U.S. NET IMPORT RELIANCE}

Commodity

ARSENIC (trioxide)

ASBESTOS

BAUXITE and ALUMINA

CESIUM

FLUORSPAR

GRAPHITE (natural)

INDIUM

MANGANESE

MICA, sheet (natural)

NIOBIUM (columbium)

QUARTZ CRYSTAL (industrial)

RUBIDIUM

SCANDIUM

STRONTIUM

TANTALUM

THALLIUM

THORIUM

GALLIUM

GEMSTONES

VANADIUM

BISMUTH

PLATINUM

GERMANIUM

IODINE

ANTIMONY

DIAMOND (dust, grit, and powder)

STONE (dimension)

POTASH

BARITE

COBALT

RHENIUM

TITANIUM MINERAL CONCENTRATES TIN

SILICON CARBIDE (crude)

ZINC

CHROMIUM

GARNET (industrial)

TITANIUM (sponge)

PEAT

SILVER

PALLADIUM

NICKEL

MAGNESIUM COMPOUNDS

TUNGSTEN

SILICON

COPPER

NITROGEN (fixed). AMMONIA

MAGNESIUM METAL

MICA, scrap and flake (natural)

VERMICULITE

PERLITE

ALUMINUM

SALT

SULFUR

PUMICE

GYPSUM

IRON and STEEL

BERYLLIUM

IRON and STEEL SLAG

CEMENT

PHOSPHATE ROCK

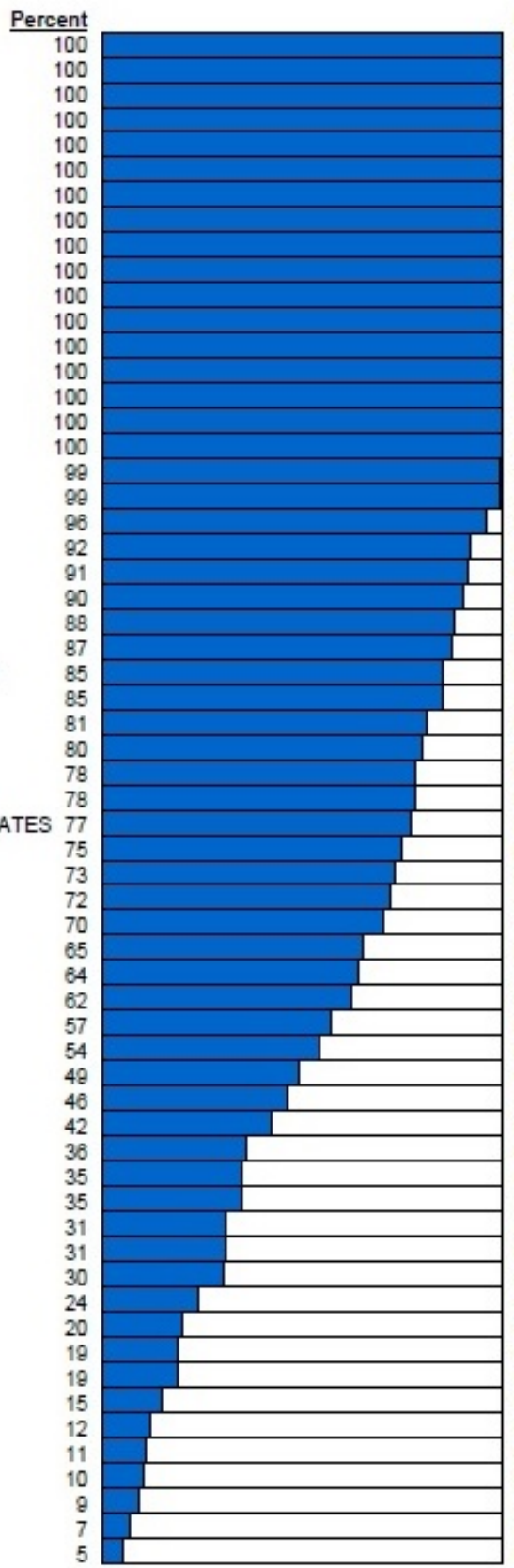

Major Import Sources (2008-11)

Morocco, China, Belgium

Canada, Zimbabwe

Jamaica, Brazil, Guinea, Australia

Canada

Mexico, China, South Africa

China, Mexico, Canada, Brazil

China, Canada, Japan, Belgium

South Africa, Gabon, Australia, China

China, Brazil, Belgium, India

Brazil, Canada, Germany

China, Japan, Russia

Canada

China

Mexico, Germany, China

China, Estonia, Germany, Kazakhstan

Germany, Russia

India, France

Germany, United Kingdom, China, Canada

Israel, India, Belgium, South Africa

Rep. of Korea, Canada, Austria, Czech Republic

China, Belgium, United Kingdom

Germany. South Africa, United Kingdom, Canada

China, Belgium, Russia, Germany

Chile, Japan

China, Mexico, Belgium, Bolivia

China, Ireland, Republic of Korea, Russi

China, Brazil, Italy, Turkey

Canada, Russia

China, India, Morocco

China, Norway. Russia, Finland

Chile, Netherlands, Germany

South Africa, Australia, Canada, Mozambique

Peru, Bolivia, Indonesia, China

China, South Africa, Romania, Netherlands

Canada, Mexico, Peru, Spain

South Africa, Kazakhstan, Russia, Mexico

India, Australia, China, Canada

Japan, Kazakhstan, China, Ukraine,

Canada

Mexico, Canada, Peru, Poland

Russia, South Africa, United Kingdom, Norway

Canada, Russia, Australia, Norway

China, Canada, Brazil, Australia

China, Bolivia, Canada, Germany

Brazil, Russia, China, Canada

Chile, Canada, Peru, Mexico

Trinidad and Tobago, Russia, Canada, Ukraine

Israel, Canada, China

Canada, China, India, Finland

South Africa, China, Brazil, Australia

Greece

Canada, Russia, China, Mexico

Canada, Chile, Mexico, The Bahamas

Canada, Mexico, Venezuela

Greece, Iceland, Mexico, Montserrat

Canada, Mexico, Spain

Canada, European Union, Mexico, Rep. of Korea

Russia, Kazakhstan, Japan, Kenya,

Japan, Canada, Italy. South Africa

Canada, Republic of Korea, China, Mexico

Morocco, Peru

Source: USGS 2013

Figure 20: U.S. import reliance on foreign minerals in 2012. 


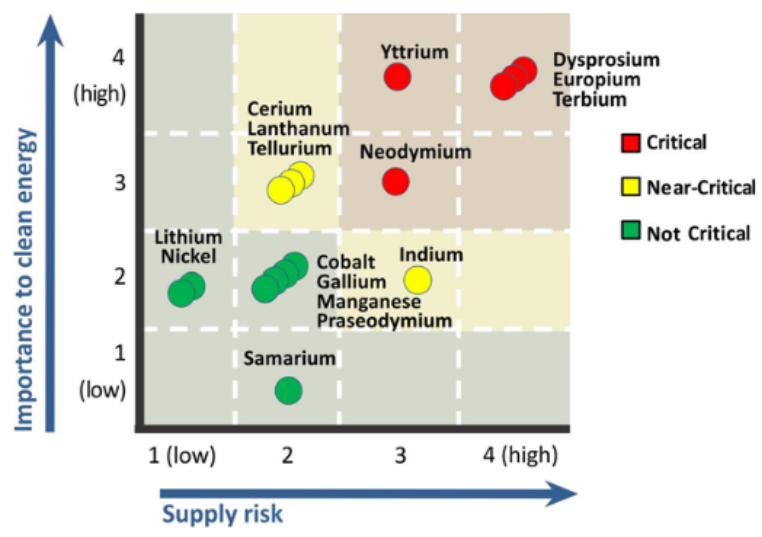

Figure ES-1. Short-Term (Present-2015) Criticality Matrix

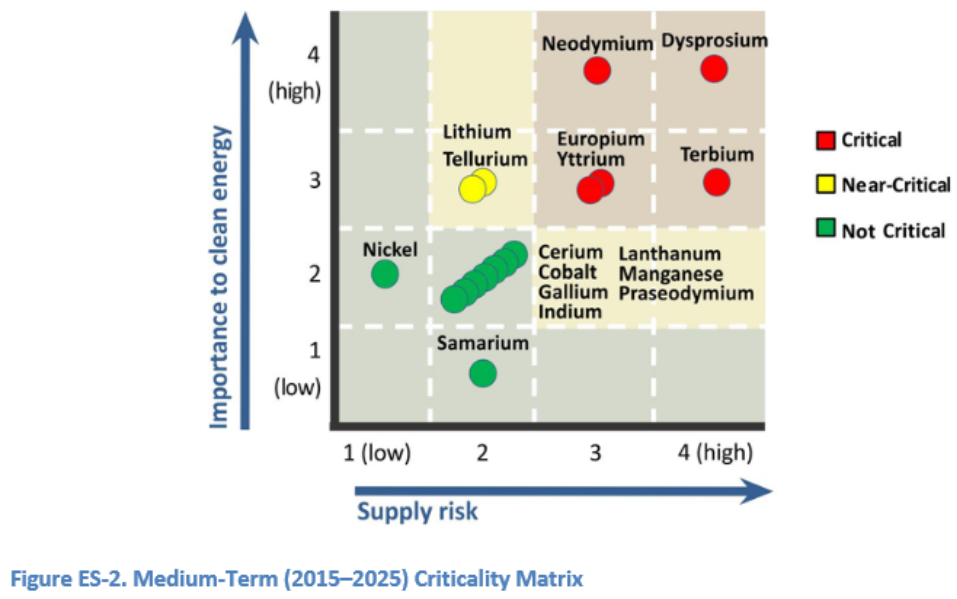

Source: DOE Critical Materials Strategy 2011

Figure 21: Strategic importance and scarcity of selected raw materials, 2011-2015

\subsubsection{Estimated Potential Revenue}

Previous estimates of potential revenue from mineral recovery have relied upon assumptions or high-level estimates only (EES 2013). This prior study estimates that a $50 \mathrm{MW}$ geothermal plant could recover $\$ 237$ million to $\$ 271$ million in mining revenue, but these estimates were not verified. Attempts to duplicate this calculation (Table 19) are not directly comparable, as the prior study's estimates include potential revenue from other minerals in addition to lithium. As a result, these values could underestimate the potential gross revenue if other minerals are also recovered. Since no geothermal recovery operations are commercially operating as of the time of this report, further operational cost estimates are needed to validate the likelihood that mineral recovery is a viable business opportunity to produce the estimated revenue stream.

At any given location, the concentration of dissolved minerals is a function of the fluid temperature and $\mathrm{pH}$, among others. Although lithium concentrations in the Salton Sea area are higher than other areas of the Imperial Valley, concentrations often vary considerably. For example, one study of the Salton Sea shows an average of $211 \mathrm{ppm}$, while another study 
measured lithium concentrations between 215-300 in the O'Neill I.I.D. \#1 well, 128-141 ppm in the Magmamax \#1 well, and as 245 ppm in the Sinclair \#4 well (Mainomi 1982).

In reviewing the following estimates of revenue in Table 19 below, it is also important to recall that the estimated MW-electric potential of a geothermal plant is a function of the reservoir volume, temperature, and well flow rate, while the actual volume of recovered minerals will be a function of the well flow rate and the mineral concentration (which is dependent on temperature). It then follows that flow rates in areas which provide high mineral concentrations (e.g., high temperature zones) may be lower than large area, lower-temperature resources. As a result, there is significant uncertainty in scaling mineral recovery potential from average well flow rates on a MW basis without first selecting wells with sufficiently high temperatures and/or mineral concentrations.

As an initial assessment, this report focuses on the recoverability and market for lithium only. While governments have not specifically identified lithium as a major strategic concern, supply security has become a significant priority of technology companies, and has spurred a wave of acquisitions and joint ventures. With this anticipated demand, opportunities to supply lithium from non-economic technologies today may become feasible in the near term. 
Table 19. Assumptions and Estimation of Annual Royalty Revenue Derived from Lithium Mineral Recovery

\begin{tabular}{|c|c|c|}
\hline Factor & Value & Source \\
\hline Royalty rate & $3 \%$ & Assumed - gross mineral recovery revenue \\
\hline Li recovery efficiency & $93 \%$ & Simbol plant estimate ${ }^{20}$ \\
\hline $\begin{array}{l}\text { Lithium Carbonate price per } \\
\text { kilogram }\end{array}$ & $\$ 6.6$ & Price for $99.5 \%$ battery grade ${ }^{21}$ \\
\hline $\begin{array}{l}\text { Percent Li in Lithium } \\
\text { Carbonate by weight }\end{array}$ & $18.8 \%$ & Mass conversion factor ${ }^{22}$ \\
\hline Brine Li concentration (mg/L) & $207-220$ & $\begin{array}{l}\text { Median - Average of available Salton Sea } \\
\text { geochemistry for wells }>200 \mathrm{C}^{23}\end{array}$ \\
\hline Density of brine (kg/L) & 1.006 & Surface density of Salton Sea fluids ${ }^{24}$ \\
\hline $\begin{array}{l}\text { Well deliverability (kg/hr per } \\
\text { MW) }\end{array}$ & $30,800-37,800$ & $\begin{array}{l}\text { Representative flow test data and measured } \\
\text { wellhead temperatures }\end{array}$ \\
\hline $\begin{array}{l}\text { Gross geothermal water } \\
\text { produced (thousand } \mathbf{k g} / \mathbf{y r} \text { ) }\end{array}$ & $120,504,541$ & $\begin{array}{l}2009 \text { data from } 21 \text { operating geothermal wells in } \\
\text { Salton Sea geothermal field }{ }^{26}\end{array}$ \\
\hline $\begin{array}{l}\text { Annual Gross Li Recovery } \\
\text { Revenue - } 50 \text { MW plant }\end{array}$ & $\$ 91-\$ 118$ million & $\begin{array}{l}=\text { Well Deliverability }[\mathrm{kg} / \mathrm{hr} \text { per MWe] X } 24 \text { hrs X } \\
365 \text { days X } 50 \mathrm{MWe} \text { X } 1 / \text { density of brine at } \\
\text { surface X average brine Li concentration X } \\
\text { technology recovery efficiency X Lithium } \\
\text { Carbonate/18.8\% Li }\end{array}$ \\
\hline $\begin{array}{l}\text { Annual Gross Li Recovery } \\
\text { Revenue - all current Salton } \\
\text { Sea }\end{array}$ & $\$ 860$ million & $\begin{array}{l}=\text { Gross Well Production }[\mathrm{kg} / \mathrm{yr}] \mathrm{X} 1000 / \text { density of } \\
\text { brine at surface X average brine Li concentration } \\
\text { X technology recovery efficiency X Lithium } \\
\text { Carbonate } / 18.8 \% \mathrm{Li}\end{array}$ \\
\hline $\begin{array}{l}\text { Annual Li Royalty from } \\
\text { Recovery - } 50 \text { MW plant } \\
\end{array}$ & $\$ 2.7-\$ 3.6$ million & $\begin{array}{l}\text { Assumed } 3 \% \text { mineral rights royalty off gross } \\
\text { revenue }\end{array}$ \\
\hline $\begin{array}{l}\text { Annual Li Royalty - all current } \\
\text { Salton Sea }\end{array}$ & $\$ 25.8$ million & $\begin{array}{l}\text { Assumed } 3 \% \text { mineral rights royalty off gross } \\
\text { revenue }\end{array}$ \\
\hline
\end{tabular}

Since mineral recovery only requires the drilling of production wells, this revenue stream could be pursued independently of geothermal power development. The $\$ 25.8$ million revenue estimate is based on the likely offshore development capacity of $370 \mathrm{MW}$ to $570 \mathrm{MW}$. Future revenue from mineral recovery will depend heavily on successful geothermal exploration efforts. Assuming all potential future geothermal capacity in the Salton Sea exhibit the average

\footnotetext{
${ }^{20} \mathrm{http} / / /$ www.nytimes.com/2011/09/28/business/energy-environment/simbol-materials-plans-to-extract-lithium-from-geothermal-

plants.html?_r=0

${ }^{21}$ http://minerals.usgs.gov/minerals/pubs/commodity/lithium/mcs-2015-lithi.pdf

${ }^{22} \mathrm{http}: / / \mathrm{www} . w e s t e r n$ lithium.com/project/conversion-table/

${ }^{23}$ Argonne National Laboratory Geothermal Geochemistry Database, based on USGS Chemical data.

${ }^{24} \mathrm{http}: / /$ earthsciences.ucr.edu/docs/awilliams_1997.pdf

${ }^{25}$ Long-term well test data from the Salton Sea Scientific Drilling Project of 370,000 kg/hr for $12 \mathrm{MWe}(1992)$,

http://www.osti.gov/geothermal/servlets/purl/7117310-R2c4nS/native/7117310.pdf and multiple Orita well flow testing by Ram Power of $500,000 \mathrm{lbs} / \mathrm{hr}(227,000 \mathrm{~kg} / \mathrm{hr})$ for $6 \mathrm{MWe}(2010)$, http://ram-power.com/current-projects/orita-california. These estimates are in line with the CRC Handbook of Mechanical Engineering, which provides a Salton Sea average flow rate of 270,000 kg/hr.

${ }^{26}$ California Division of Oil, Gas, and Geothermal Resources (2010) Annual Report of Geothermal Operations. ftp://ftp.consrv.ca.gov/pub/oil/annual_reports/2009/0109geofin_09.pdf
} 
characteristics assumed above, IID could realize an additional \$39.3 million to \$71.7 million in royalty revenues. ${ }^{27}$

\subsubsection{Lithium}

Although lithium recovery from subsurface or continental brines is a proven technology, no projects to date have produced lithium from geothermal brines on a commercial scale.

Commercial extraction from continental brines is based primarily on solar evaporation, which currently has a recovery efficiency of approximately $50 \%$. By concentrating the brine prior to filtration techniques for lithium, other minerals "salt" out as fluid evaporates. A new technology by POSCO still uses evaporation and is specific to continental brines, but also includes a column filtration process ${ }^{28}$ to increase lithium recovery efficiency to above $80 \%{ }^{29}$

The Hudson Ranch geothermal plant partnered with Simbol Minerals for their extraction processes. ${ }^{30}$ Thus, this section focuses on a review of Simbol's patented technologies.

Figure 22 shows the general concept underlying Simbol's process for lithium extraction. This technology embodies the use of a coated porous inorganic substrate to selectively capture lithium, which is then washed for lithium removal and substrate recovery. Simbol's patent covers the use of substrates made from a range of materials: diatomaceous earth (i.e., silica-based), iron oxide, alumina (or activated alumina), or resins (e.g., poly aluminum hydroxyl chloride). The use of porous materials increases the amount of active areas for extraction, leading to high efficiency.

In 2013, Simbol reported that it had successfully produced battery grade lithium carbonate $(99.99 \% \text { purity })^{31}$ from their additional patented process to remove impurities in the aqueous solution. ${ }^{32}$ However, Simbol Technologies recently shut down operations at the Hudson Ranch plant. Based on available news sources, it appears that the plant had already established technical viability of their extraction process, and that operations were discontinued due to lack of financial resources. ${ }^{33}$

\footnotetext{
${ }^{27}$ Assumes production wells for an additional 680 to $1240 \mathrm{MW}$ geothermal energy capacity to be available by 2030 (see estimates of geothermal capacity in this report).

${ }^{28}$ https://www.google.com/patents/US7157065?dq=POSCO+lithium\&hl=en\&sa=X\&ei=OOUKVbS_D4qLNr7Ug5gJ\&ved=0CB0Q6AEwAA

${ }^{29} \mathrm{http}: / /$ lithiuminvestingnews.com/7146/posco-lithium-brine-processing-technology-extraction-li3-energy-simbol-chile-signumbox/

${ }^{30} \mathrm{http}: / / \mathrm{www} \cdot$ renewableenergyworld.com/rea/news/article/2012/05/49-9-mw-hudson-ranch-i-geothermal-plant-unveiled-in-calif

${ }^{31} \mathrm{http}: / / \mathrm{www}$. simbolmaterials.com/who_we_are.htm

${ }^{32}$ https://www.google.com/patents/EP2536663B1?cl=en\&dq=simbol+lithium+carbonate\&hl=en\&sa=X\&ei=

DxQLVYfWMoSXNtu0g9AE\&ved=0CEEQ6AEwBQ

${ }^{33} \mathrm{http}: / /$ www.desertsun.com/story/tech/science/energy/2015/02/03/lithium-plans-doubt-simbol-materials-fires-dozens/22828207/
} 


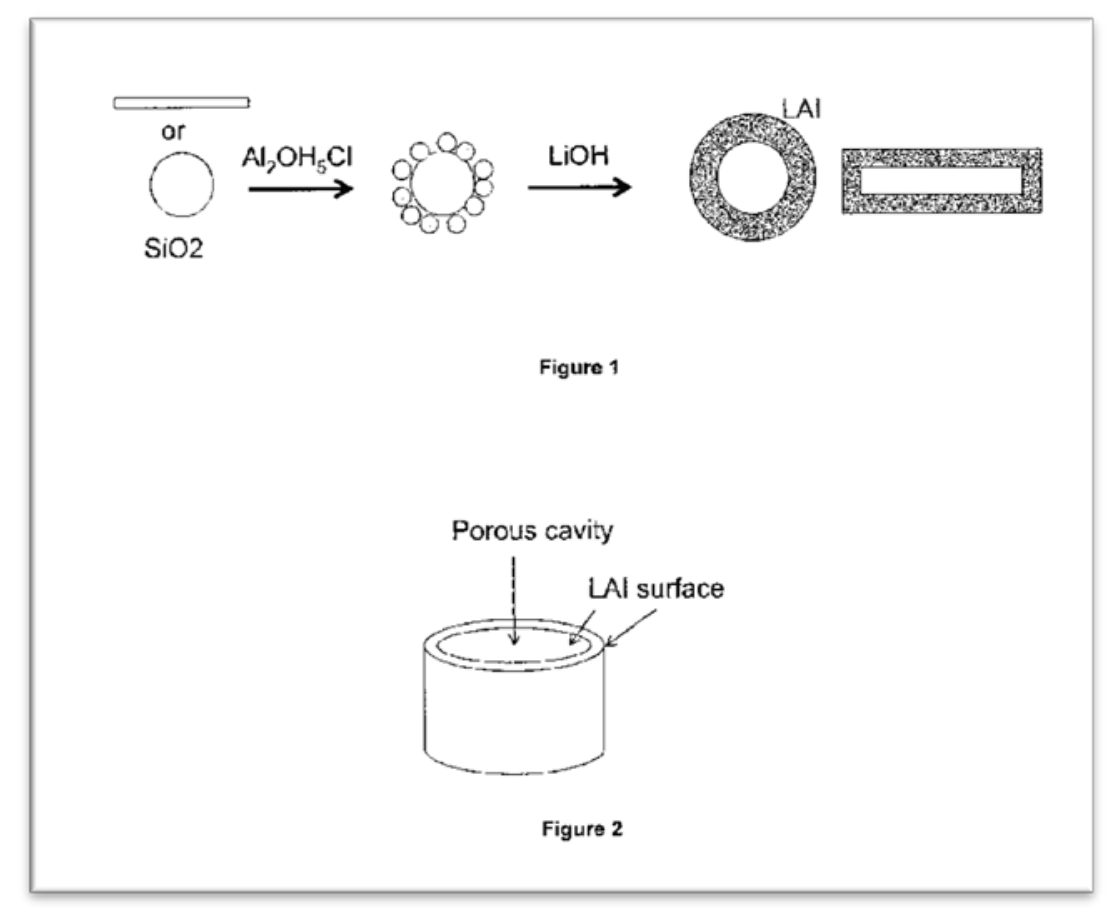

Figure 22: Schematic of lithium capture from geothermal brines using a substrate ${ }^{34}$

\section{Lithium Supply}

Currently, lithium is produced via either concentration from subsurface brines or concentration from hard rock mineral deposits. Depending on the end use, the form in which lithium is sold varies between compounds, metal, or mineral concentrates.

World lithium carbonate production in 2014 was estimated by the USGS to total 36,000 tons, a 5\% increase from the 2013 total of 34,200 tons. Spodumene mining in Australia has remained the largest source of produced lithium, but is nearly matched by an increase in brine-derived lithium in Chile. As shown in Table 20, Argentina and China were the other largest producers of lithium carbonate from brines, while Zimbabwe and Portugal have derived production from spodumene and lepidolite mining, respectively.

Interest in lithium exploration has increased recently in the United States, Argentina, Bolivia, and Chile, with a primary focus in these countries on brine resources. By contrast, Canada and Australia have primarily focused on lithium from pegmatites. ${ }^{35}$ Within the United States, interest has primarily been in the geothermal brines of the Salton Sea, as well as in the subsurface brines and clays of Nevada. Finally, preliminary studies in Wyoming suggest that reservoir brines in the Rock Springs Uplift could provide nearly $228,000 t$ of lithium. ${ }^{36}$

\footnotetext{
${ }^{34}$ Lithium extraction composition and method of preparation, US Patent US 8637428 B1 34.

${ }^{35} \mathrm{http}: / /$ minerals.usgs.gov/minerals $/$ pubs $/ \mathrm{mcs} / 2015 / \mathrm{mcs} 2015$.pdf.

${ }^{36} \mathrm{http}: / /$ minerals.usgs.gov/minerals/pubs/commodity/magnesium/myb1-2013-mgcom.pdf.
} 
Table 20: Summary of Global Lithium Supplies (Production, Reserves, and Resources) and Sources*

\begin{tabular}{|c|c|c|c|c|c|}
\hline & \multicolumn{2}{|c|}{ Production } & \multirow[t]{2}{*}{ Reserves } & \multirow[t]{2}{*}{ Resources } & \multirow[t]{2}{*}{ Source Type } \\
\hline & 2013 & 2014 & & & \\
\hline $\begin{array}{l}\text { United } \\
\text { States }\end{array}$ & 870 & w & 38,000 & $5,500,000$ & carbonate \\
\hline Argentina & 2,500 & 2,900 & 850,000 & $6,500,000$ & subsurface brine \\
\hline Australia & 12,700 & 13,000 & $1,500,000$ & $1,700,000$ & ore: spodumene \\
\hline Brazil & 400 & 400 & 48,000 & 180,000 & concentrates \\
\hline Chile & 11,200 & 12,900 & $7,500,000$ & $>7,500,000$ & subsurface brine \\
\hline China & 4,700 & 5,000 & $3,500,000$ & $5,400,000$ & $\begin{array}{l}\text { subsurface brine and } \\
\text { concentrates }\end{array}$ \\
\hline Portugal & 570 & 570 & 60,000 & N/A & ore: lepidolite \\
\hline Zimbabwe & 1,000 & 1,000 & 23,000 & N/A & $\begin{array}{l}\text { ore: amblygonite, } \\
\text { eucryptite, lepidolite, } \\
\text { petalite, spodumene }\end{array}$ \\
\hline Bolivia & & $\mathrm{N} / \mathrm{A}$ & $\mathrm{N} / \mathrm{A}$ & $9,000,000$ & subsurface brine \\
\hline World Total & 34,000 & 36,000 & $13,500,000$ & $39,500,000$ & \\
\hline
\end{tabular}

* Lithium as mineral concentrate, lithium carbonate, lithium chloride, and lithium hydroxide $\mathrm{N} / \mathrm{A}=$ Not available on a comparable basis

$\mathrm{W}=$ Withheld for business confidentiality

Source: USGS 2013 Minerals Yearbook ${ }^{37}$; USGS Minerals Commodity Survey January $2015^{38}$

Only one company has disclosed that it mines lithium in the United States (Rockwood Lithium). The company mines lithium carbonate from a 6,000 t/yr facility in Silver Peak, NV, and produces battery-grade lithium from a 5,000 t/yr facility in Kings Mountain, NC. Rockwood also produces lithium carbonate and chloride from brine holdings in Chile. FMC also holds a Lithium Division in which it processes compounds in Bessemer City, NC, but the lithium itself is sourced from holdings in Argentina. Western Lithium is currently exploring opportunities to produce lithium from clays in Nevada. ${ }^{39}$

Globally, lithium supply is primarily concentrated into a few major companies. Beyond FMC and Rockwood, other major suppliers in the lithium market include Chemical \& Mining Co. of Chile Inc. and the Chinese materials company Chengdu Tianqi, who also recently acquired Australian company Talison Lithium. ${ }^{40}$ Finally, as of January 12, 2015, global chemicals company Albermarle acquired Rockwood Holdings, parent company to Rockwood Lithium. ${ }^{41}$

New interest in resource exploration has been led primarily by private startups in Australia and Canada, such as Orocobre and Lithium Americas, but multiple upstream companies, such as Toyota Tsusho, have also signaled significant interest in acquiring lithium assets to secure their

\footnotetext{
${ }^{37} \mathrm{http}: / /$ minerals.usgs.gov/minerals/pubs/mcs/2013/mcs2013.pdf.

${ }^{38} \mathrm{http}: / /$ minerals.usgs.gov/minerals/pubs/mcs/2015/mcs2015.pdf.

${ }^{39} \mathrm{http} / / /$ investorintel.com/rare-earth-intel/berry-on-marketing-trends-igniting-interest-in-batteries-and-their-raw-materials/.

${ }^{40} \mathrm{http}: / /$ seekingalpha.com/article/2845376-orocobre-joins-the-lithium-oligopoly.

${ }^{41} \mathrm{http}: / / \mathrm{www}$. rockwoodlithium.com/news-events/news/news/archive/showing/article/albemarle-corporation-completes-acquisition-of-rockwoodholdings/.
} 
supply chain. Toyota has acquired exclusive rights to the lithium carbonate from Orocobre's project in Argentina, which may allow Toyota to expand its electric vehicle production. ${ }^{42}$

\section{Lithium Demand}

Globally, lithium is consumed primarily as lithium compounds rather than as lithium minerals (79\% vs. $21 \%$, respectively). Lithium carbonate accounted for the largest share of consumption in 2012 at approximately $48 \%$, with lithium hydroxide in second at $15 \%$. While the quality of lithium carbonate consumed was evenly split between technical-grade and battery-grade, the vast majority of lithium hydroxide was consumed as technical grade rather than battery grade (12\% versus $3 \%$ of total consumption, respectively). ${ }^{43}$ While multiple formulations of lithium batteries exist that require varying quantities of lithium, the lithium content of a lithium-ion cell is approximately 0.3 times the rated capacity in ampere-hours. For every typical automotive battery at 70-amp hours, this equates to 21 grams of lithium. ${ }^{44}$ This content ratio would also hold for energy storage applications using lithium-ion cells.

In terms of global trade, lithium imports to the United States have originated primarily from Chile (58\%) and Argentina (39\%), but the volume of imports overall decreased nearly $20 \%$ in 2013 from 2012 levels. Exports of lithium produced in the United States primarily went to Japan $(30 \%)$, Germany $(22 \%)$, and Belgium $(9 \%){ }^{45}$

In terms of end uses, the majority of lithium is consumed for ceramics and glass in a wide range of industrial uses. Figure $23^{46}$ illustrates the diversity of demand as of 2013 . Other uses for lithium beyond those listed include alloys, chemicals (agrochemicals, pharmaceuticals, pool chemicals, dyes, pigments), additives to cement and concrete, and welding, among others. ${ }^{47}$ Within the consumption of lithium for batteries, Figure $24^{48}$ shows global revenues from lithiumion batteries in 2012 were split between three major applications: consumer electronics, industrial, and transportation applications.

\footnotetext{
${ }^{42} \mathrm{http}: / /$ seekingalpha.com/article/2845376-orocobre-joins-the-lithium-oligopoly.

${ }^{43}$ Technical grade is a slightly lower purity than battery grade (e.g., $99.3 \%$ purity vs. $99.5 \%$, respectively)

http://www.fmclithium.com/Portals/FMCLithium/content/docs/DataSheet/QS-PDS-1059\%20r1.pdf.

${ }^{44}$ http://batteryuniversity.com/learn/article/is_lithium ion_the ideal_battery; http://www.allaboutcircuits.com/vol_1/chpt_11/3.html

${ }_{45}^{4}$ USGS Minerals Yearbook 2015

${ }^{46}$ USGS Minerals Yearbook 2015; Merriman, 2014

${ }^{47}$ USGS Minerals Yearbook 2015, Rockwood Lithium GmbH, 2014

${ }^{48}$ USGS Minerals Yearbook 2015; Merriman, 2014
} 


\section{Global Lithium End Markets}

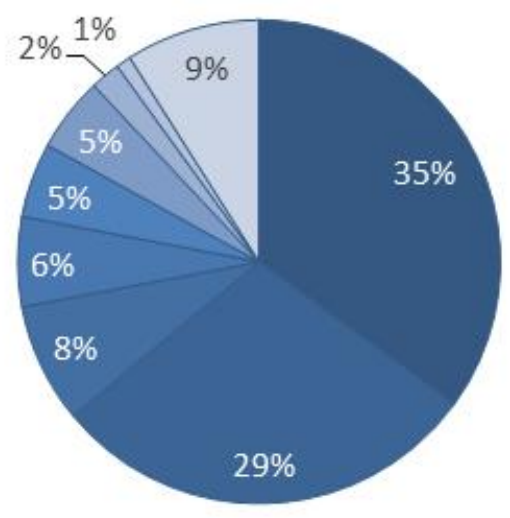

Ceramics and glass

Rechargeable Batteries

Lubricating Greases

Continuous Casting

Mold Flux Powers

Air Treatment

$\square$ Polymer Production

$\square$ Primary Batteries

$\square$ Primary Aluminum

Production

$\square$ Other Uses

Source: USGS Minerals Yearbook 2015

Figure 23: Breakdown of 2013 global lithium demand by end use products.

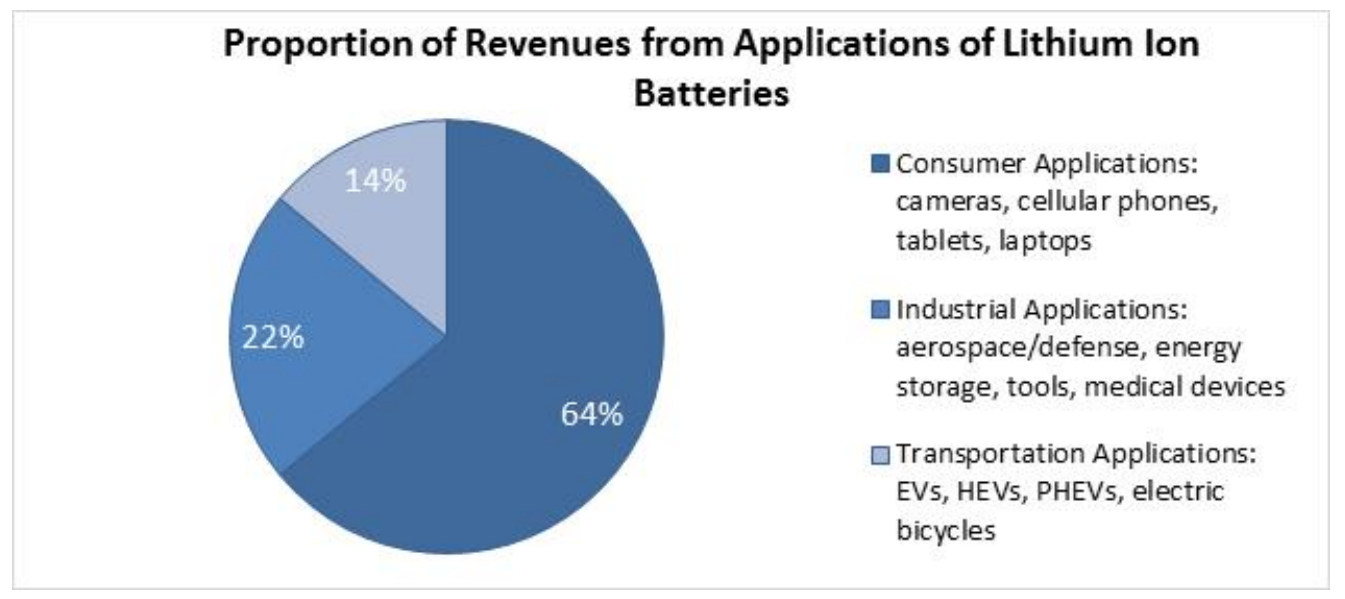

Source: USGS Minerals Yearbook 2015

Figure 24: Breakdown of 2012 global revenues of lithium ion batteries by application.

While growth of lithium-ion cell production globally has increased by $16 \%$ annually on average, estimates of annual growth in lithium demand is projected in the near term to average $11 \%$ per year, driven largely by demand for rechargeable batteries. ${ }^{49}$ Energy storage applications are likely to also use lithium-ion batteries, but expected growth in demand is most likely for lithium ion batteries for vehicles- projections of which range from $22 \%$ to $41 \%$ annually until 2020 (Figure 25).

\footnotetext{
${ }^{49}$ Tesla Motors, Inc., 2014; Roskill 2013
} 


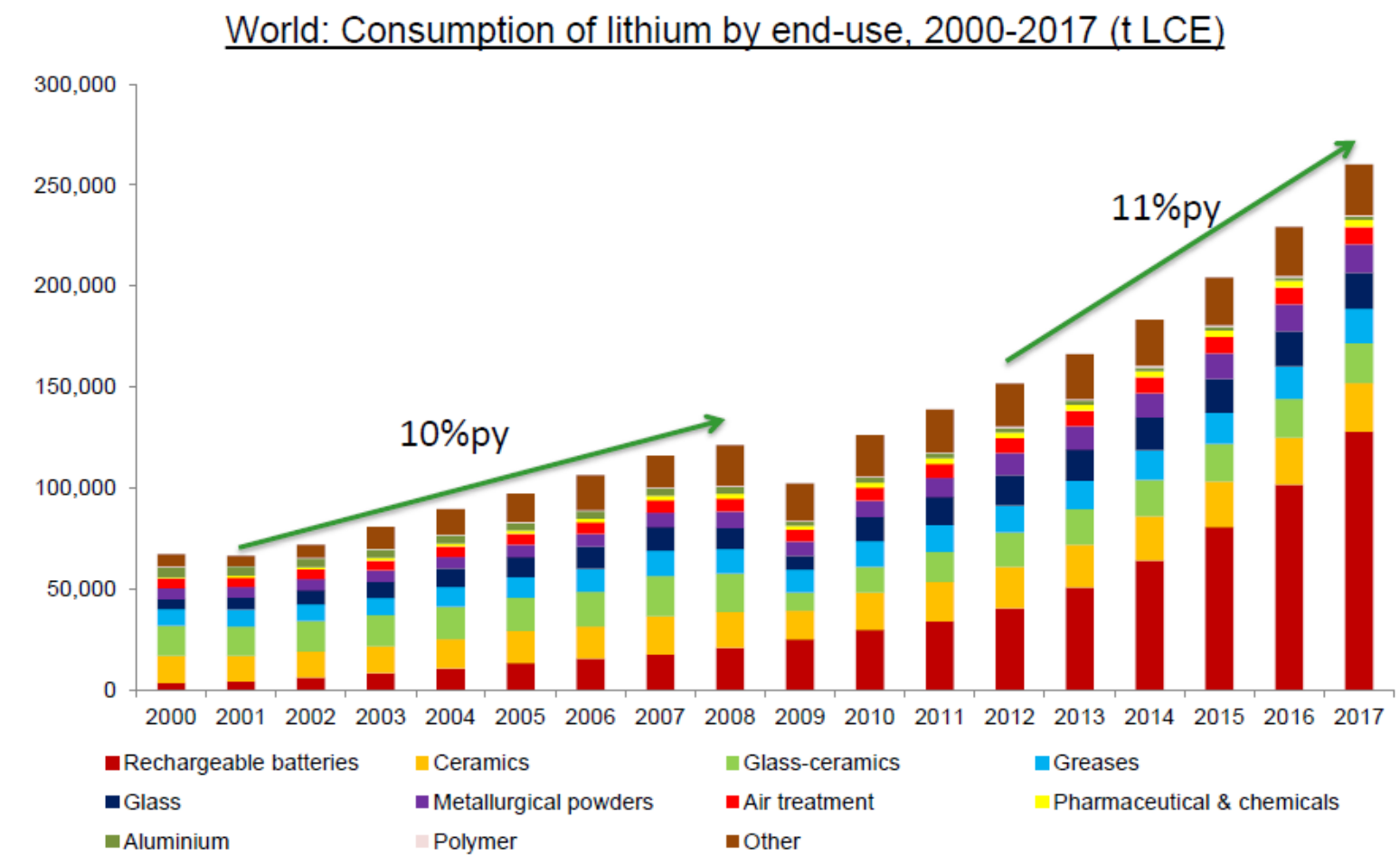

Source: Roskill 2013

Figure 25: Historic and projected global lithium consumption, by end use.

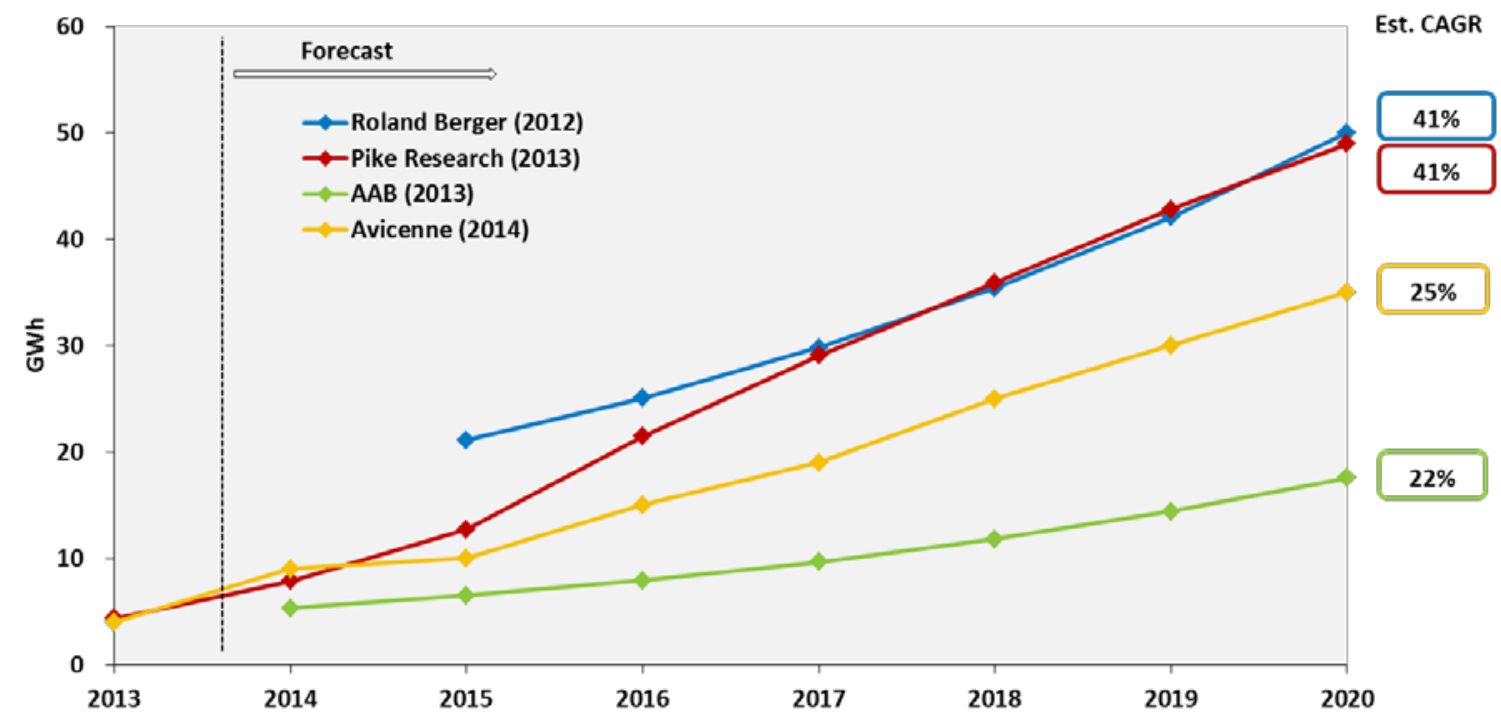

Figure 26: Projected growth in global li battery demand for automotive applications. ${ }^{50}$

The potential demand from battery production is thus not to be discounted; in China alone, domestic revenues from lithium-ion batteries increased $84 \%$ largely due to manufacturing for electric bicycles. ${ }^{51}$ The entrenched supply chain for lithium ion batteries in Asia (shown as trade

\footnotetext{
${ }^{50}$ Chung, Donald, and Elgqvist, Emma, Automotive Lithium-ion Battery (LIB) Supply Chain and U.S. Competitiveness Considerations, 2014

${ }^{51}$ USGS Minerals Yearbook 2015; Antaike Minor Metal Monthly, 2014
} 
flows in Figure 27) suggests this demand is not likely to shift regionally unless Tesla's planned gigafactory comes online in the United States.

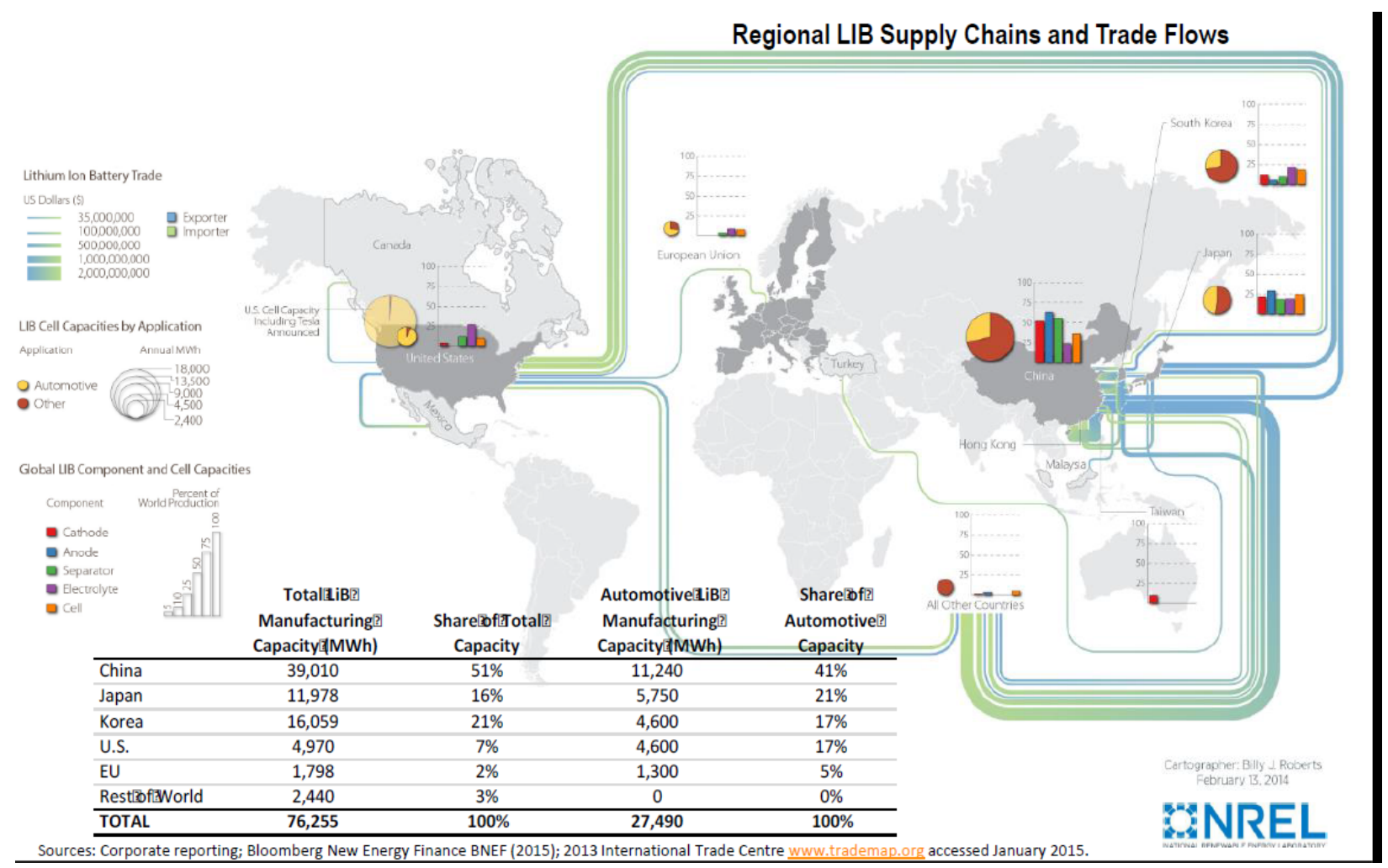

Figure 27: Regional supply chain capacity and trade flow for lithium-ion battery components.

\section{Lithium Prices}

Lithium is not a traded commodity, and thus spot prices are not readily available. Nevertheless, prices for customs unit values of lithium carbonate were $\$ 4.29$ per imported kilogram in 2013, and \$5.64 per exported kilogram. Prices for customs values of lithium hydroxide were $\$ 5.64$ per imported kilogram and $\$ 7.43$ per exported kilogram. For both types, exported lithium commands a higher price of approximately $28 \%$ over imports, potentially suggesting that United Statesderived lithium is of higher quality. However, these exported prices have declined $10 \%$ from 2012; imported prices of lithium carbonate rose $4 \%$, and imported prices of lithium hydroxide fell 5\% from 2012. ${ }^{52}$ Within China, 2013 prices for lithium ranged from $\$ 6,550$ to $\$ 6,900$ per metric ton for lithium hydroxide, while lithium carbonate ranged from $\$ 5,700$ to $\$ 6,810$ per metric ton; batter-grade lithium carbonate demanded $\$ 6,380$ to $\$ 6,810$ per metric ton, while technical-grade lithium carbonate demanded $\$ 5,700$ to $\$ 6,100$ per metric ton. ${ }^{53}$

\subsubsection{Other Recoverable Minerals}

Beyond the extraction of lithium, Simbol has also developed patented technologies for highpurity silica, manganese, and zinc. A schematic of this process is reproduced in Figure 61.

\footnotetext{
${ }^{52}$ USGS Minerals Yearbook 2015; Merriman, 2014

${ }^{53}$ USGS Minerals Yearbook 2015; Syrett, 2014
} 


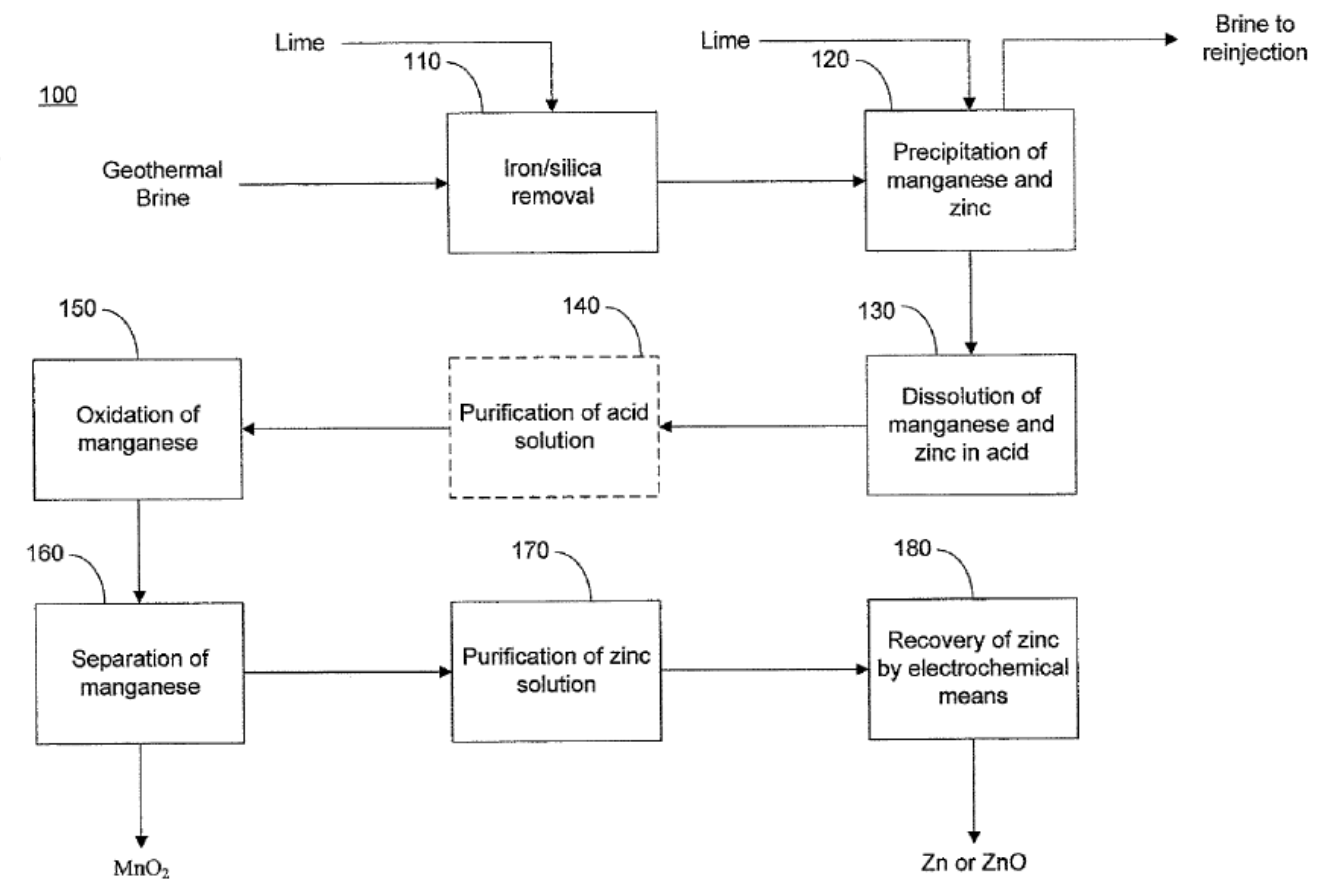

Figure 28: Process diagram for manganese and zinc removal from geothermal brines. ${ }^{54}$

High-purity zinc has been recovered economically and commercially from geothermal brines using a combination of solvent extraction, ion exchange, and electrowinning processes. ${ }^{55}$ CalEnergy's mineral extraction plant produced $99.99 \%$ zinc from $2002-2004$, and closed due to financial issues unrelated to mineral recovery. ${ }^{56}$

Morton International successfully operated a plant in the 1960s in Imperial Valley to extract various salts (calcium chloride, potassium chloride) from geothermal brines, and closed the facility due to a drop in prices. A similar plant in Mexico that extracted potassium chloride for fertilizers (Fertilizantes Mexicanos) was abandoned in the final stages of construction due to a drop in international prices. ${ }^{57}$

The most successful example of mineral recovery has been the extraction of boric acid, sodium perborate, and ammonium carbonate from the brines at Lardarello, Italy. While mineral recovery of boric acid has occurred at Larderello since $1818,{ }^{58}$ boric acid was produced both commercially and in high volumes between 1850 and $1975 .^{59}$

\subsubsection{Conclusion}

This analysis currently focuses on the market landscape for lithium from geothermal brines because of the combination of near-commercial technology potential and the immediate and

\footnotetext{
${ }^{54}$ Simbol Minerals, Selective Recovery of Manganese \& Zinc from Geothermal Brines, US Patent 8454816 B1

${ }^{55}$ https://www.google.com/patents/WO2009117354A2?cl=en\&dq=calenergy +zinc + extraction\&hl= en\&sa $=$ X\&ei=RAwLVbrjB4eigwS_roH4DA\&ved=0CB4Q6AEwAA

${ }^{56} \mathrm{http}: / /$ www.renewableenergyworld.com/rea/blog/post/print/2014/08/value-creation-from-geothermal-fluids-beyond-batteries-for-tesla

${ }^{57} \mathrm{http}$ //www.renewableenergyworld.com/rea/blog/post/print/2014/08/value-creation-from-geothermal-fluids-beyond-batteries-for-tesla

${ }^{58} \mathrm{http}: / /$ www.ilpalio.org/brief_larderello.htm

${ }^{59} \mathrm{http}: / /$ www.renewableenergyworld.com/rea/blog/post/2014/08/value-creation-from-geothermal-fluids-beyond-batteries-for-tesla?page=2
} 
increasing demand for lithium-ion battery applications in both vehicles and energy storage. However, geothermal mineral recovery in the region could potentially target the extraction of multiple minerals, such as magnesium or zinc, in order to mitigate risk from price volatility.

While rare earth elements exist in geothermal brines, the concentration of these elements is often below detection levels. Determining the potential resource supply of these elements from geothermal brines requires further fundamental research. Furthermore, no technologies to date offer the potential to selectively recover these elements. However, should these elements become technically recoverable many rare earth elements have been identified as critical or strategic due to their projected demand in renewable energy and technology applications.

\subsection{Hydrogen and Renewable Energy}

California has several policies in place to accelerate the adoption of hydrogen fuel cell electric vehicles (FCEV) into the light- and medium/heavy-duty vehicle markets. California is a national leader in support for FCEV markets, and the Los Angeles metropolitan area in particular is recognized as a key early market among global cities in Germany, Japan and South Korea ${ }^{60}$ Los Angeles is unique in having a high population density, a high density of early adopters of advanced vehicle technologies (based upon historical sales of hybrid electric vehicles), and severe air quality issues requiring deep reductions in NOx emissions. As a state, California also leads in market support mechanisms for low-carbon transportation fuels and zero emission vehicles (ZEV), where the category of ZEVs includes plug-in hybrid electric vehicles, battery electric vehicles, and FCEVs. California's Low Carbon Fuel Standard is designed to accelerate innovation and market adoption of low carbon transportation fuels, and the ZEV Mandate requires auto makers to sell ZEVs within the state to meet increasingly stringent compliance targets. In addition to the Low Carbon Fuel Standard, California Air Resources Board (CARB) has established a renewable hydrogen requirement of $33 \%$ for any projects supported by state funds. ${ }^{61}$

A handful of automakers have just begun to commercialize FCEVs, with Hyundai offering a production vehicle for lease in 2014 and Toyota offering a production vehicle for sale or for lease in 2015. With the vehicle technology moving forward, infrastructure availability is a limiting barrier to successful market growth. ${ }^{62}$ As evidence of the state's commitment, the California Energy Commission has recently allocated resources towards an unprecedented number of hydrogen stations in preparation for early FCEV market adoption, with the current 13 open public stations expected to expand to over 50 stations in coming years. Ultimately, current legislation allows up to 100 stations to be supported through around 2024, exceeding the 68 stations considered essential for early market growth. ${ }^{63}$ Though projections of market growth are relatively modest, with some 18,500 vehicles expected in California by $2020,{ }^{64}$ Los Angeles is the focus of FCEV marketing activities and currently leads northern California in hydrogen station installations.

\footnotetext{
${ }^{60} \mathrm{http}: / /$ www.theicct.org/hydrogen-fuel-cell-vehicle-infrastructure

${ }^{61} \mathrm{http}: / /$ www.arb.ca.gov/msprog/hydprod/hydprod.htm

${ }^{62}$ Greene, D.L., Leiby, P.N., James, B.D., Perez, J., Melendez, M., Milbrandt, A., Unnasch, S., and Hooks, M. (2008). Analysis of the Transition to Hydrogen Fuel Cell Vehicles \& the Potential Hydrogen Energy Infrastructure Requirements (2008 ed.). Oak Ridge National Laboratory.

${ }^{63} \mathrm{http}$ //cafcp.org/sites/files/Roadmap-Progress-Report2014-FINAL.pdf

${ }^{64} \mathrm{http}: / /$ www.arb.ca.gov/msprog/zevprog/ab8/ab8 report final june2014.pdf
} 
The emphasis on building FCEV markets first in southern California is evident in the station location maps indicated in Figure 29. The left-hand map indicates 11 public hydrogen stations in operation as of early March 2015, while the right-hand map indicates the planned locations of the 50 stations funded to date by the California Energy Commission. As shown, early efforts to install stations have focused on Los Angeles, with only two public stations currently installed in northern California.
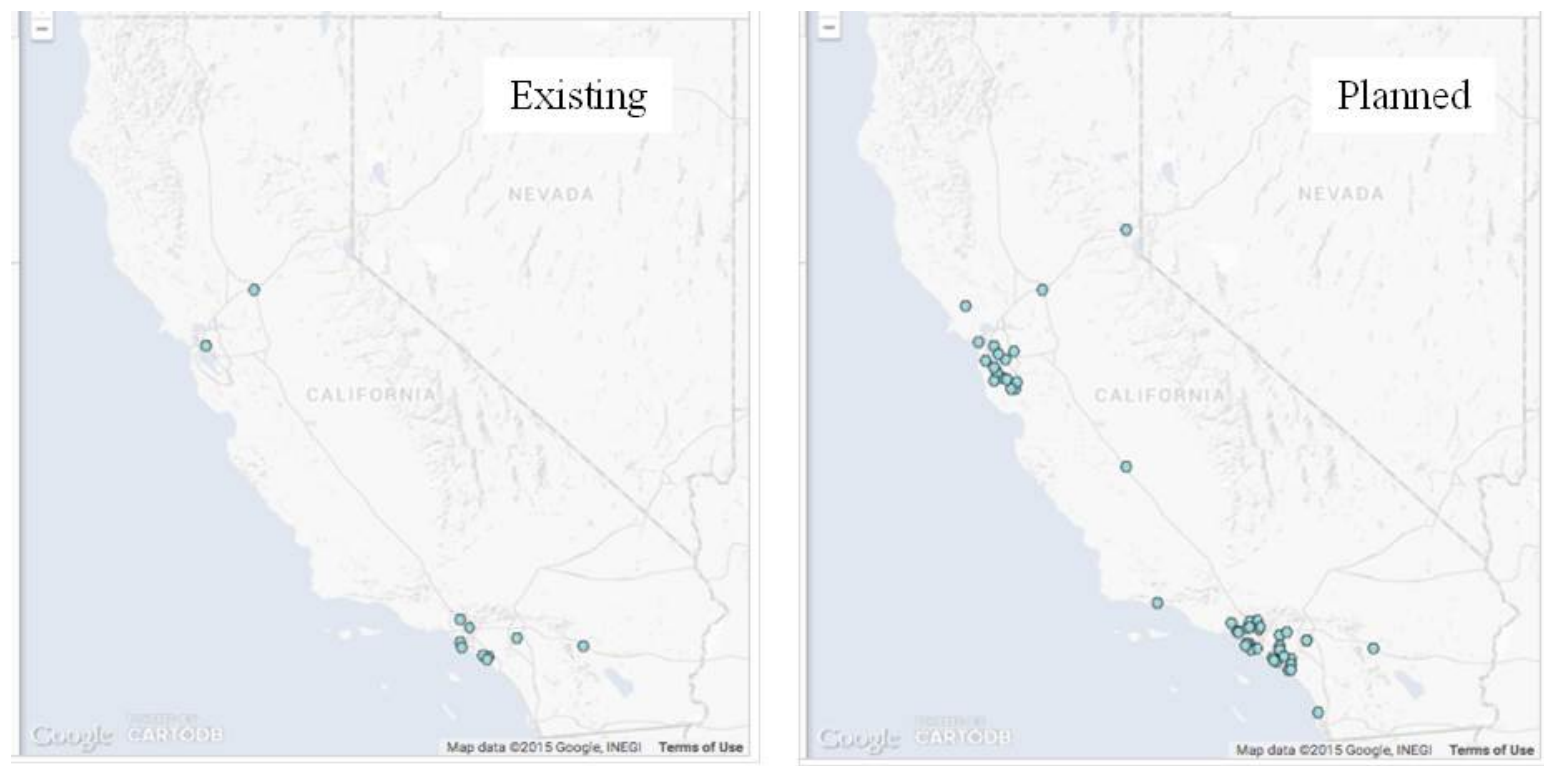

Figure 29. Existing and planned hydrogen station locations. ${ }^{65}$

Hydrogen can be produced from any primary energy resource, including coal, natural gas, nuclear resources, wind, solar and geothermal. For the Salton Sea region solar and geothermal resources are of particular interest. The delivery of hydrogen is a significant infrastructure undertaking, and Salton Sea is unique in being located some 150 miles from Los Angeles, and being traversed by major natural gas pipelines, as indicated in Figure 30. Early hydrogen delivery would be expected by gaseous or liquid tank truck, but at higher production volumes gaseous pipeline proves more economical. Rights of way for new hydrogen pipelines would prove relatively manageable due to existing natural gas pipelines within and along the northern border of Salton Sea (Figure 30). In addition, direct injection of hydrogen into natural gas pipelines is also a possible delivery method for early market growth. These and other issues are discussed in the following sections.

${ }^{65}$ AFDC Station Locator, available at: http://www.afdc.energy.gov/locator/stations 


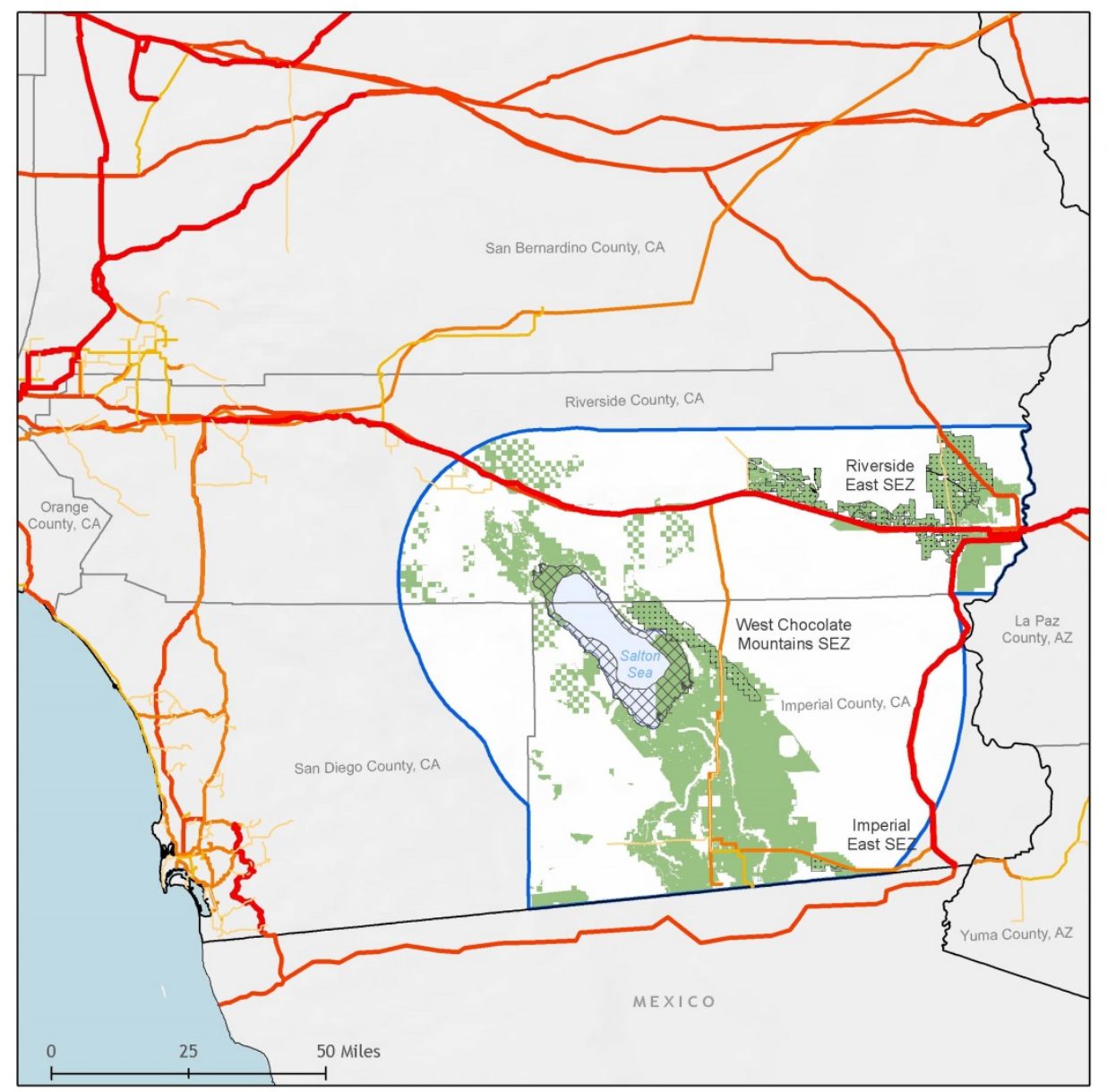

Salton Sea, California

RE Developable Land

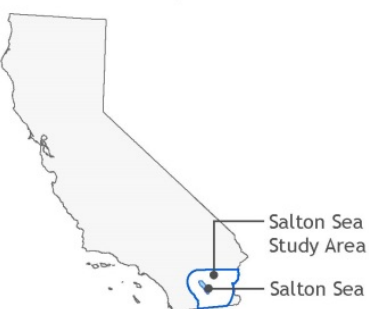

Natural Gas Pipelines Diameter (inches)

$36 \cdot 48$

$26-35$

$16 \cdot 25$

$11 \cdot-15$

- $6 \cdot 10$

Salton Sea Plan Area

Solar Energy Zones

Salton Sea Playa

RE Developable Land

Data sources: National Renewable Energy Laboratory; Desert Renewable Energy Conservation Plan; Riverside

Imperial Irrigation District; BLM;

Ventyx Velocity Suite 2014

This map was produced by

National Renewable Energy Laboratery

for the Department of Energy.

WNREL

Figure 30. Major natural gas pipelines in the Salton Sea region

\subsubsection{Hydrogen production}

Most hydrogen used in commercial and industrial applications today is made from large-scale steam methane reforming (SMR) units collocated with petroleum refineries, as well as much smaller capacity electrolysis units for facilities where onsite production has an economic advantage over truck delivery. Most SMR hydrogen production is installed at petroleum refineries for use in removing sulfur and upgrading petroleum products. Electrolysis involves passing an electric current through a reactor to split water into gaseous hydrogen and gaseous oxygen. Given the very low prices of natural gas in the Unites States, SMR production is much more economical than electrolysis.

The Salton Sea region has significant potential to produce renewable hydrogen relative to other parts of the United States, due to the intensity of both geothermal and solar resources. Relying upon the technical potential estimates discussed earlier in this report for electricity generation from geothermal of solar resource via PV, it is possible to project comparable hydrogen production potentials using simple conversion efficiency values. These are reviewed in the upper portion of Table 21, for three types of electrolysis conversion:

- Current technology. Electrolysis at relatively small-scale with current conversion efficiency. 
- Future technology. Projection of a mature future technology, mass produced and at a large scale with improved conversion efficiency.

- High temperature electrolysis. An electrolysis operating at high temperature in which water splitting is achieved with reduced electricity input (for example, a solid oxide electrolysis system). Electricity input requirement is reduced (here estimated at 45 $\mathrm{kWh} / \mathrm{kg}$ ) due to use of thermal energy as an input to the conversion process. Note that very high temperatures are required to allow for this type of electricity efficiency improvement, on the order of $300^{\circ} \mathrm{F}$ or more (Balta et al. 2009).

As indicated in the table, the electricity production potentials for Salton Sea translate to hydrogen production potentials on the order of millions of kilograms $(\mathrm{kg})$ of hydrogen per day. As a point of reference, one $\mathrm{kg}$ of hydrogen has approximately the same energy content as a gallon of gasoline. Because hydrogen FCEVs are expected to be about twice as efficient as a conventional gasoline or diesel vehicle, the price of hydrogen can be divided by two to estimate a gallon gasoline equivalent (gge) per mile cost. For example, if a driver pays $\$ 10$ per $\mathrm{kg}$ and then drives twice as far as a normal ICE vehicle, the cost to the hydrogen FCEV driver is roughly $\$ 5 /$ gge.

The bottom section of Table 21 indicates the corresponding number of FCEVs that could be supported with these levels of hydrogen production. These vehicle totals range from 4.3 to 6.5 million FCEVs from hydrogen produced using geothermal electricity and 16.3 to 24.6 million FCEVs using PV solar electricity. Given that there are 0.8 light-duty vehicles (LDV) per person on average in the United States, and the current population of 24 million people within the Southern California region is expected to grow to 39 million by $2050^{66}$, these production potentials would be sufficient to supply some $14 \%$ to $79 \%$ percent of all LDVs in Southern California in 2050 (if replaced with FCEVs).

Table 21. Hydrogen Technical Production Potentials and Total FCVs Supported

\begin{tabular}{|l|c|c|c|}
\hline Resource & \multicolumn{3}{|c|}{ Electrolysis Production } \\
\hline efficiency & $\begin{array}{c}\text { Current } \\
\text { Technology } \\
\text { (million kg/day) }\end{array}$ & $\begin{array}{c}\text { Future } \\
\text { Technology } \\
\text { (million kg/day) }\end{array}$ & $\begin{array}{c}\text { High Temp. } \\
\text { Electrolysis } \\
\text { (million kg/day) }\end{array}$ \\
\hline Geothermal & $55 \mathrm{kWh} / \mathrm{kg}$ & $50 \mathrm{kWh} / \mathrm{kg}$ & $45 \mathrm{kWh} / \mathrm{kg}$ \\
\hline Solar PV & 3.0 & 3.3 & 3.7 \\
\hline & 11.4 & 12.5 & 13.9 \\
\hline fuel economy & $65 \mathrm{mpgge}$ & 80 mpgge & $80 \mathrm{mpgge}$ \\
\hline Geothermal & 4.3 & 5.8 & 6.5 \\
\hline Solar PV & 16.3 & 22.1 & 24.6 \\
\hline (Source: DOE Hydrogen and Fuel Cells Program Record 2014 &
\end{tabular}

Current projections by $\mathrm{DOE}^{67}$ estimate future large-scale electrolysis production systems to provide hydrogen at a profited cost of $\$ 4.20$ per $\mathrm{kg}$ (assuming an electricity price of $\$ 0.069 / \mathrm{kWh}$

\footnotetext{
${ }^{66} \mathrm{http} / / / \mathrm{www}$. america2050.org/southern california.html

${ }^{67} \mathrm{http} / / /$ www.hydrogen.energy.gov/pdfs/14004_h2_production_cost_pem_electrolysis.pdf
} 
and efficiency of $50.2 \mathrm{kWh}$ per kg), and current small-scale systems to provide hydrogen at a profited cost of $\$ 5.14$ (assuming an electricity price of $\$ 0.061 / \mathrm{kWh}$ and efficiency of $54.6 \mathrm{kWh}$ per $\mathrm{kg}$ ). These cost estimates assume a production capacity of $50,000 \mathrm{~kg}$ per day for the future case, and $1,500 \mathrm{~kg}$ per day for the current case. The smaller current electrolysis case requires 3.4 MW of electricity at full power, and the large central future case requires $105 \mathrm{MW}$. Both estimates assume full utilization, and associated costs would increase at the lower utilization rates expected for remote, dedicated production from variable renewable resources such as solar.

The combination of geothermal and solar resources allows for multiple opportunities to improve upon the conversion of solar energy by utilizing renewable geothermal heat. In addition to the improved electrical efficiency discussed above for electrolysis, there may be an opportunity for hydrogen liquefaction efficiency to also be improved (Kanoglu et al. 2007), and the higher output pressure of high-temperature electrolysis units can reduce costs for gaseous compression equipment. Moreover, with sufficiently high temperatures, advanced thermochemical conversion processes may prove economic as these technologies become commercialized. For example, the $\mathrm{Cu}-\mathrm{Cl}$ cycle (Balta et al. 2010) could prove promising and improve upon more conventional electrolysis systems. Alternatively, direct solar conversion processes may prove promising over the mid- to long-term (e.g., 10-20 years).

These production costs must be added to delivery costs, which include transmission, storage, distribution and dispensing, before determining the cost "at the pump" for FCEV drivers. These additional delivery costs may range from $\$ 2$ per $\mathrm{kg}$ to $\$ 5$ per $\mathrm{kg}$ and are very sensitive to volume and distance. As rough guidelines for the 150 mile delivery distance to Los Angeles, for relatively large production facilities within the Salton Sea region, exceeding about 10,000 to $20,000 \mathrm{~kg} /$ day, liquid hydrogen truck delivery may start to become competitive with gaseous truck delivery. At much larger volumes, around 0.5 to $1.0 \mathrm{million} \mathrm{kg} / \mathrm{day}$, gaseous pipeline delivery will begin to be more economical than liquid truck delivery. More detailed logistical and cost analyses with inputs specific to the region would be required to better understand these transitions between delivery modes at higher production capacities.

\subsubsection{Delivery System Options}

Some back-of-the-envelope cost estimates for liquid hydrogen (LH2) and pipeline delivery can provide an order of magnitude perspective on the market viability of producing hydrogen in the Salton Sea region. Costs associated with hydrogen delivery are likely to be favorable relative to the rest of the country for production in the Salton Sea area due to the combination of large-scale production and relatively short delivery distances to the Los Angeles basin and surrounding urban areas. Delivery to today's stations is largely by way of high pressure gaseous hydrogen trucks. At larger production volumes, LH2 trucks, costing approximately \$1 million each and carrying 4,000 kg of hydrogen, could prove economically viable for delivery from the Salton Sea region. Assuming a future production volume of 200,000 kg/day, about $40 \mathrm{LH} 2$ delivery trucks would be required, as well as a LH2 truck terminal near the point of production (perhaps with gathering lines from multiple production sites). The trucks themselves, therefore, would be on the order of $\$ 40$ million in capital, not including the terminal. If typical stations at this point in time provide roughly $1200 \mathrm{~kg}$ /day to a regional FCEV fleet, this fleet of LH2 delivery trucks could supply a nominal network of some 150-200 hydrogen fueling stations with renewable hydrogen. At \$4-\$5 million per station at that average capacity (Melina and Penev 2013), the station network would have a capital cost of $\$ 0.6$ to $\$ 1.0$ billion. This network of stations would 
have evolved over time, and would be switched to renewable LH2 delivery as production increases over time. Also, in actuality, LH2 delivery trucks would only be one mode of hydrogen supply within an even larger network of stations, which initially would be provided hydrogen produced from central SMR production facilities through either gaseous hydrogen or LH2 trucks. Therefore, in theory, an existing fleet of delivery trucks could switch from a natural gas central plant to a renewable production plant over time as capacity increases and if and when economics prove viable.

For larger production volumes in the long term, say 1 million $\mathrm{kg} / \mathrm{day}$, gaseous pipeline delivery would likely prove more economical than LH2 truck delivery. A general rule of thumb for hydrogen pipelines is $\$ 1$ million per mile, escalating to $\$ 1.5$ million per mile or even $\$ 2$ million per mile with right-of-way (ROW) or terrain issues. Pipeline diameter does tend to increase overall costs, but installation and ROW costs tend to exceed material costs. A roughly 150 mile transmission pipeline to the Los Angeles basis could therefore cost some 150-250 million, not including any storage requirements and compressor stations. The distribution network within the urban area would also include significant costs, as 1 million $\mathrm{kg}$ /day could supply a network of approximately 830 hydrogen stations with an average output of $1200 \mathrm{~kg} /$ day. Again, assuming \$4 million to \$5 million per station for that average capacity (Melina and Penev 2013), the station network would have a capital cost of $\$ 3.3$ billion to $\$ 4.1$ billion. Again, this station network would have evolved over time. As a point of reference, there are about 3,000 major conventional (Melaina and Bremson 2008) gasoline stations serving the Los Angeles basin today.

\subsubsection{Market Potential for Hydrogen Demand in Southern California}

There are technical innovation and learning opportunities to reduce the cost of renewable hydrogen production below the costs reviewed in the previous section. Regardless of progress with these production and delivery technologies, there are significant uncertainties around the rate at which FCEVs might be deployed within the LDV and medium- and heavy-duty vehicle fleets. New advanced vehicle technologies can be inhibited from market growth by a number of cost and non-cost (Stephens 2013) market barriers. The market potential scenario discussed below is based upon a hydrogen success case developed by a National Academy of Sciences committee to determine a nation market potential of FCEVs. This scenario has been disaggregated to the urban area scale using a consistent scenario development framework within NREL's Scenario Evaluation and Regionalization Analysis (SERA) model. ${ }^{68}$ Within this disaggregation of a national market share expansion trend, the city of Los Angeles is an early niche market and achieves more rapid market growth than any other city, but within the scenario total FCEV sales are still balanced at a national scale as successive cities begin to adopt FCEVs.

One change to the NAS study, which was published in 2008, is that the early transition years have been adjusted (pushed back in term of market share growth) to reflect more recent adoption estimates from the California Environmental Protection Agency, Air Resources Board (CARB 2004). As indicated in Figure 31, the simulated vehicle sales in Los Angeles approximate the point estimates for total California FCEV sales in 2014, 2017, and 2020, shown as squares. The Los Angeles FCEV sales fall short of these statewide estimates as more FCEVs are sold into other California urban areas. The rapid growth in subsequent years results in significant

\footnotetext{
${ }^{68}$ http://www.hydrogen.energy.gov/pdfs/progress10/vii_ 1 bush.pdf
} 
economies of scale in vehicle production by 2025 to 2027 and exponential growth thereafter to achieve the same market share as the NAS report by 2050. Given the context provided in the NAS 2008 report, this rate of market growth should be considered a maximum feasible growth rate, adjusted in the early years for near-term expectations.

This disaggregated scenario for Los Angeles provides some perspective on the technical production potentials discuss above. For example, a renewable production facility with 100,000 $\mathrm{kg}$ /day capacity would dominate the FCEV market up to approximately 2025 to 2030, and therefore prove economically infeasible, especially given competition from hydrogen produced from natural gas. As additional market forces level the playing field for low-carbon fuels, and as sufficient demand for hydrogen develops with increased FCEV market adoption, this 100,000 $\mathrm{kg}$ /day facility would be a small part of the overall demand by approximately 2035 to 2040 , when the total maximum feasible demand approaches 1.5 million $\mathrm{kg} /$ day to 2.7 million $\mathrm{kg} / \mathrm{day}$. Similarly, a 1 million $\mathrm{kg}$ /day facility would provide sufficient hydrogen for approximately $25 \%$ of all Los Angeles demand by 2050, and may therefore place significant upward pressure on prices within that timeframe, especially if sales are more modest than those indicated in Figure 32. On the other hand, in order to meet the California goal of an $80 \%$ reduction in greenhouse gases (GHG) (across all sectors) by 2050, most of the hydrogen supply in 2050 would need to be very low carbon; only a small fraction could still be produced from conventional natural gas. Provision of low-carbon hydrogen at this scale is consistent with others' studies of the technology adoption trends required to meet the $2050 \mathrm{GHG}$ goal within the transportation sector (McCollum et al. 2012) and (Melaina and Webster 2011).

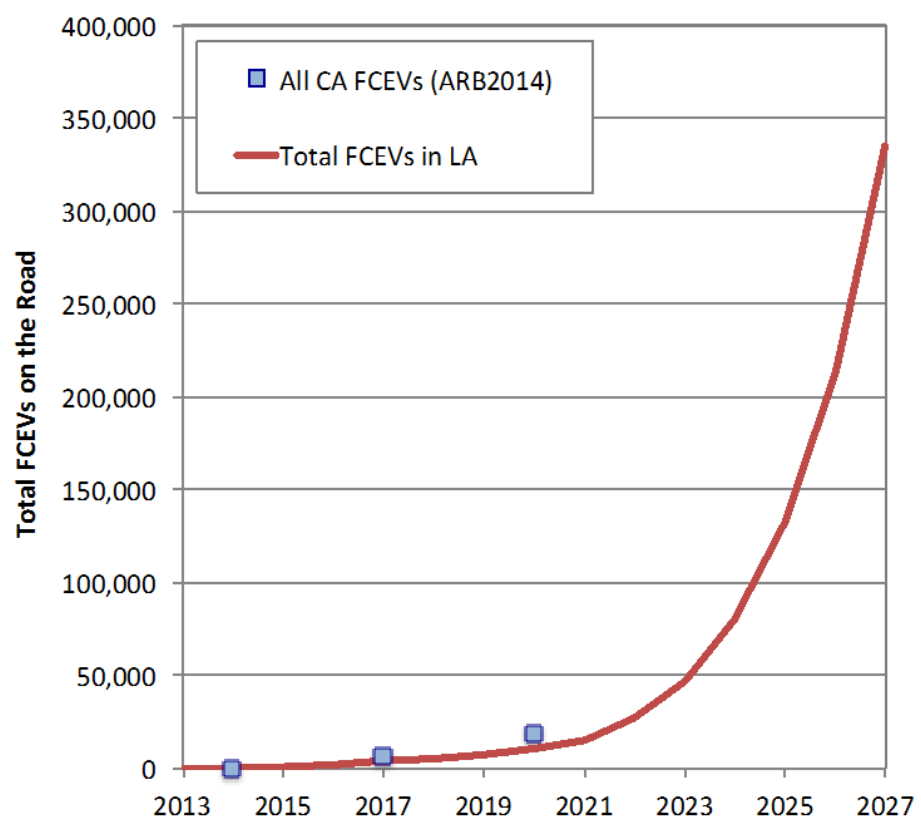

Figure 31. FCEV sales in Los Angeles and California in a hydrogen success scenario. 

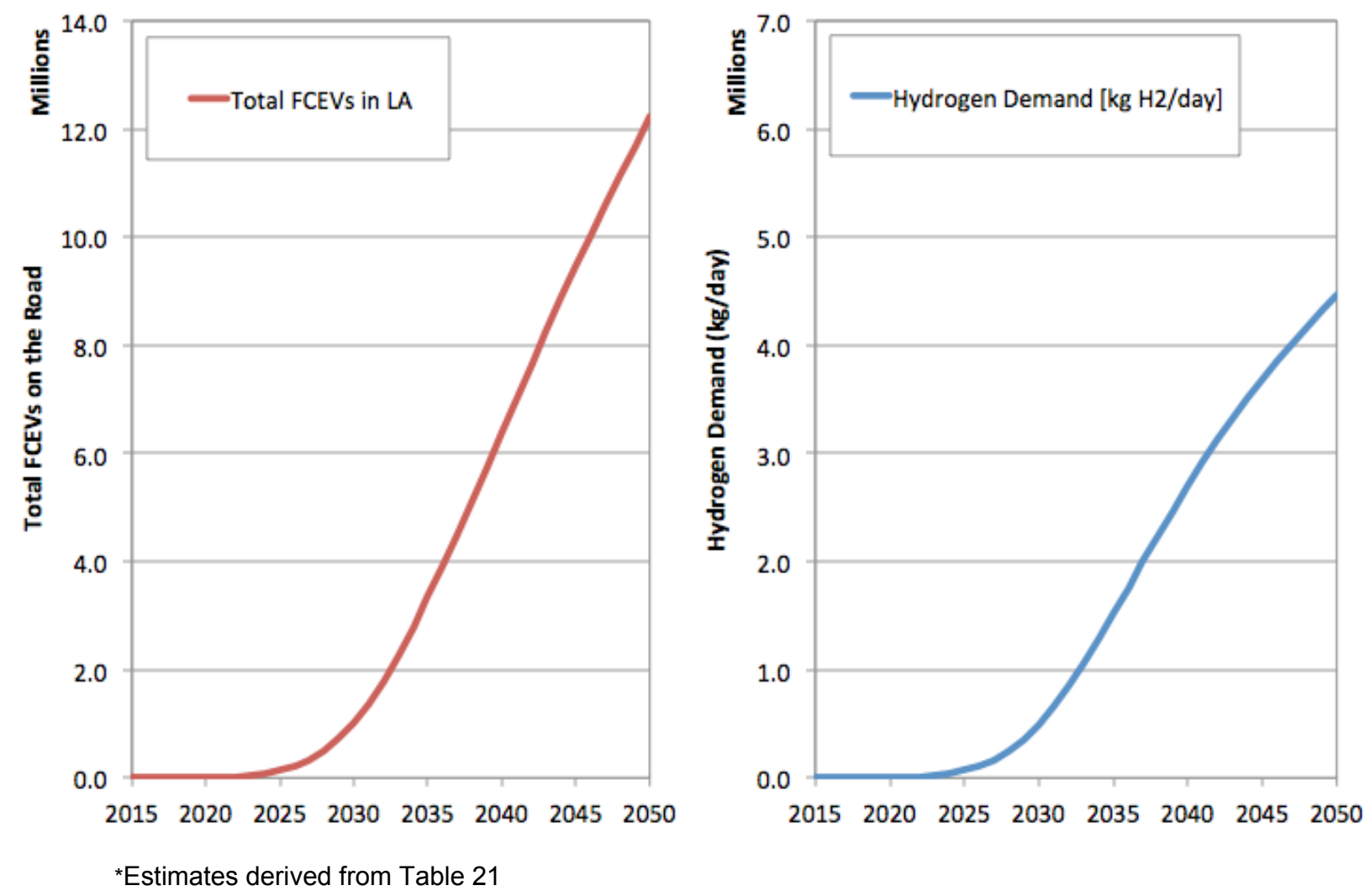

Figure 32. Total FCEV sales in Los Angeles (left) and resulting hydrogen demand (right).

\section{Additional Potential Revenues}

Given that it appears that there will be minimal economic headroom for a Salton Sea restoration tax on renewable energy development in the region, additional potential revenue generation mechanisms for the Salton Sea Authority have been explored. These potential revenues include 1) existing federal and state revenue sources, as well as discussion of 2) additional potential funding and restoration cost reduction options. The development of these potential revenue streams will typically require a change in policy, development of the offshore playa, or further commercialization of a renewable technology. 
Table 22. Summary of Potential Revenues
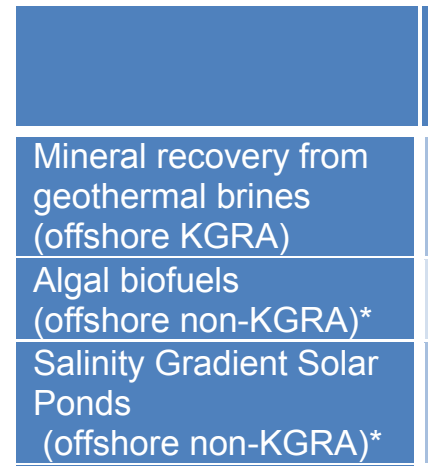

Solar PV
(offshore non-KGRA)*

Solar PV (onshore BLM

Solar Energy Zones)

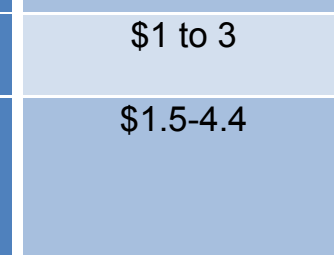

\section{Other:}

Desert Renewable

Energy Conservation

Plan - Habitat

Restoration

Total (annual):

\section{4 year total:}

\section{Potential Future Conditions \\ [Annual Millions]}

$\$ 0$ to 25.8

Assumes offshore development of up to $570 \mathrm{MW}$ of geothermal, $3 \%$ IID royalty rate on gross lithium sales

$\$ 1.2$ to 2.3

Assumes $\$ 3 / \mathrm{gal}$ cost competiveness by $2030,1-2 \%$ IID land lease rate

$\$ 0.6$ to 1.6

Assumes $\$ 80-\$ 100 / \mathrm{MWh}$ PPA, $90 \%$ capacity factor, IID land lease rate (1-2\% - gross proceeds).

Notes: See Appendix C for full calculations

Assumes $\$ 40-60 / M W h$ PPA, $23.2 \%$ capacity factor, IID land lease rate (1-2\% - gross proceeds).

Assumes passage of HR 596 and development of 1.8 GW of BLM SEZ's. Assumes \$40-60/MWh PPA, 23.2\% capacity factor, royalty rate between $1-2 \%$ - gross proceeds.

\begin{tabular}{|c|l} 
\$3.5 to $\$ 44.6$ & $\begin{array}{l}\text { Lower case based on allocable revenues to desert } \\
\text { pupfish habitat, upper case is for full habitat restoration } \\
\text { amounts for Imperial \& Riverside }\end{array}$ \\
\hline$\$ 5.6$ to 77.8 & $\begin{array}{l}\text { The potential revenues above typically require a } \\
\text { change in policy, development of the offshore playa, or }\end{array}$ \\
\hline technological developments.
\end{tabular}
change in policy, development of the offshore playa, or

* The potential development of off-shore acreage outside of the KGRA is mutually exclusive. e.g: Full development of the available acreage by algal biofuels precludes development by Solar PV or Salinity Gradient Solar Ponds. Total revenue estimates reflect the highest and lowest potential revenues from these three technologies (\$0.6 to 3 million annually).

\subsection{Desert Renewable Energy Conservation Plan}

This revenue range assessment is a rough estimate based on the Draft DRECP report released in September, 2014; the final report may change substantially after the integration of comments from local, state and federal stakeholders. Currently, the proposed funds in the Draft DRECP appear to be dedicated to two main classes of activities: land acquisition mitigation and habitat restoration. Land acquisition mitigation refers to the purchase of land that will be set aside as undevelopable, in order to preserve existing wildlife habitat. Habitat restoration (also referred to as "Non-acquisition mitigation) within the report) refers to habitat infrastructure and actions, such as starling control, that restore existing degraded habitat.

The report currently identifies DRECP implementation fees (proposed environmental permitting fees required to implement the DRECP's objectives) as the primary source of funding for the proposed mitigation and conservation measures. However, given the variation in mitigation costs by region and Covered Activity, the proposed fees will be determined on a project-byproject basis. In order to ensure that renewable energy development in the development focus areas remains viable, the DRECP will attempt to establish greater permitting and environmental cost certainty and integrated transmission planning. While the Draft DRECP assumes $20 \mathrm{GW}$ of renewable energy development in development focus areas, this is their upper bound estimate from a renewable energy development standpoint. 
The draft report examined four scenarios, as well as a no-action and preferred alternative. These scenarios examined different allocations of implementation fees between land acquisition mitigation and habitat restoration. For the purposes of this report, the preferred alternative was examined, as it appeared to be the most likely scenario. Only habitat restoration revenues were considered. Table 23 is a summary of habitat restoration activities, and their DRECP-estimated costs from Appendix I of the draft report. ${ }^{69}$

Table 23. NPV of Non-Acquisition Mitigation Cost Estimates (\$ Millions)

\begin{tabular}{|l|c|c|c|c|c|}
\hline County & $\begin{array}{l}\text { Habitat } \\
\text { Enhancement }\end{array}$ & $\begin{array}{l}\text { Fencing \& } \\
\text { Signage }\end{array}$ & $\begin{array}{l}\text { Roost Habitat } \\
\text { Creation, } \\
\text { Enhancement, and } \\
\text { Protection }\end{array}$ & $\begin{array}{l}\text { Predator, } \\
\text { Cowbird, or } \\
\text { Starling } \\
\text { Control }\end{array}$ & $\begin{array}{l}\text { Total } \\
\text { Estimated } \\
\text { Cost }\end{array}$ \\
\hline Imperial & $\$ 184.7$ & $\$ 16.3$ & $\$ 4.6$ & $\$ 4.6$ & $\$ 210.2$ \\
\hline Inyo & $\$ 20.0$ & $\$ 1.8$ & $\$ 0.5$ & $\$ 0.5$ & $\$ 22.8$ \\
\hline Kern & $\$ 61.2$ & $\$ 5.4$ & $\$ 1.5$ & $\$ 1.5$ & $\$ 69.7$ \\
\hline Los Angeles & $\$ 25.3$ & $\$ 2.2$ & $\$ 0.6$ & $\$ 0.6$ & $\$ 28.8$ \\
\hline Riverside & $\$ 211.0$ & $\$ 18.6$ & $\$ 5.3$ & $\$ 5.3$ & $\$ 240.0$ \\
\hline San \\
Bernardino & $\$ 284.9$ & $\$ 25.1$ & $\$ 7.1$ & $\$ 7.1$ & $\$ 324.3$ \\
\hline San Diego & $\$ 15.1$ & $\$ 1.3$ & $\$ 0.4$ & $\$ 0.4$ & $\$ 17.1$ \\
\hline TOTAL & $\$ 802.3$ & $\$ 70.6$ & $\$ 20.1$ & $\$ 20.1$ & $\$ 913.0$ \\
\hline
\end{tabular}

Source: Draft DRECP, Draft DRECP and EIR/EIS Appendix I, 2014

Due to the number of threatened species in the Imperial and Riverside region, it is likely that only a portion of these mitigation costs would be available for Salton Sea mitigation or restoration activities. Several species live in close proximity to the Salton Sea, including: most notably, the Desert Pupfish, but also the Yuma Clapper Rail, the Burrowing Owl, and potentially other threatened or endangered migratory bird species relying on the Salton Sea as a stopover on the Pacific flyway. Although these species live in close proximity to the Salton Sea, the regional impacts of the Salton Sea's degradation could adversely impact additional species, and therefore merit additional funding as well. Current activities supported under the Habitat Enhancement category include reseeding/replanting native vegetation, reintroducing native wildlife, restoring natural contours, restoring lost or degraded hydrologic or geomorphic functions, and increasing groundwater availability for dependent species.

Given that the Desert Pupfish appears to be the species most directly affected by the degradation of the Salton Sea, the costs associated with this species have been estimated based on the following excerpts from the Draft DRECP. "Threats to the species include loss and degradation of suitable habitat through groundwater pumping or water diversion; contamination from agricultural return flows, as well as other contaminants; and physical changes to water properties involving suitable water quality; the effect of disease, competition, or predation; inadequate regulatory mechanisms; and endocrine disruptors". ${ }^{70}$

\footnotetext{
${ }^{69}$ Draft DRECP and EIR/EIS Appendix 1. Cost Estimate Methodology and Categories for DRECP Mitigation Cost Estimation. August 2014.

${ }^{70}$ DRECP Chapter III. 7. Biological Resources Chapter III. 7. 6. 1. 3. August 2014. P.160.
} 
The revenue estimates performed are high-level, and based on limited habitat restoration information in the Draft DRECP, which includes a modeled habitat of 8,000 acres for the desert pupfish, which appears to be the primary proposed intervention. Two revenue calculations were performed to establish potential ranges for DRECP revenue for Salton Sea restoration. First, an estimation of the total revenue based on the portion of the DRECP's modeled desert pupfish required habitat of 8,000 acres was calculated, out of the total 47,000 planned acres for federally endangered species in the Imperial Borrego region (Figure 33). ${ }^{71}$ By this pro-rata allocation of planned funds dedicated to the Imperial Borrego region, it could be expected that up to $17 \%$ of the $\$ 184.7$ million, or $\$ 31.4$ million, could potentially be allocated to desert pupfish habitat. Given that this $\$ 31.4$ million is a net-present-value, this amount was undiscounted based on the DRECP's 3.6\% discount rate and 25 year term to $\$ 49.58$ million, or $\$ 3.5$ million annually.

Alternatively, the upper revenue estimate assumed that the full Imperial (\$184.7) and Riverside (\$211) County Habitat Restoration costs were allocated to Salton Sea restoration efforts. These estimates were also undiscounted to $\$ 44.6$ million in annual revenues.

Although the Draft DRECP also includes a section on air quality, and mentions the Salton basin as a nonattainment area for PM10 particulates, there are currently no proposed mitigation or restoration activities associated with this issue.

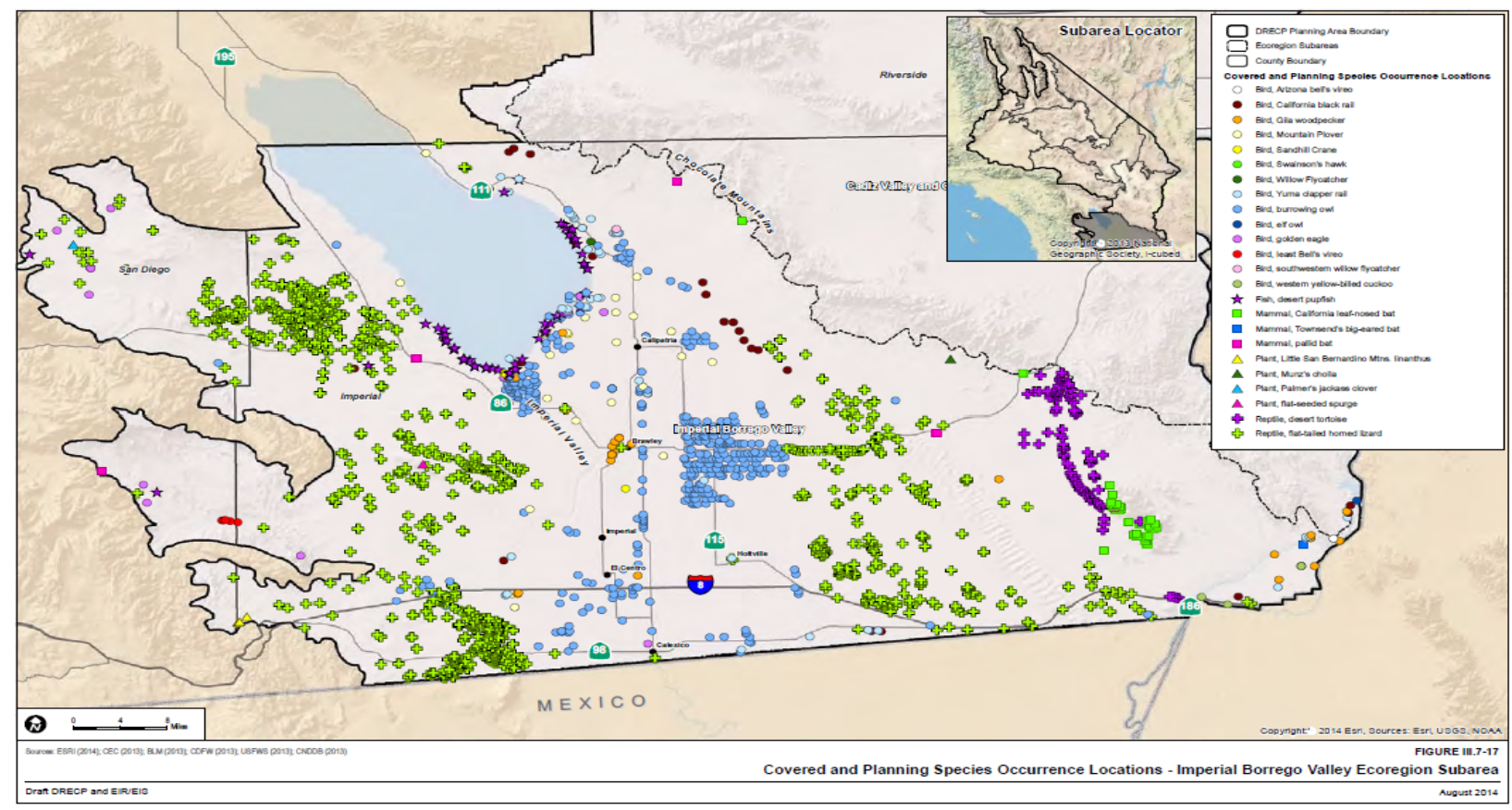

Source: DRECP Chapter III. 7. Biological Resources

Figure 33. Biological resources map of the Imperial Borrego region.

\subsection{Land and Water Conservation Fund}

The Land and Water Conservation Fund was established by Congress in 1965, and designates a portion of offshore oil and gas leases to federal and state conservation uses. According to the

${ }^{71}$ DRECP Chapter III. 7. Biological Resources Chapter III. 7. 6. 1. 3. August 2014. P.127. 
DRECP, "California has received an average of approximately $\$ 50$ million annually over the 45 year life of the fund, although less in recent years due to declining funding allocations.

According to the California Department of Parks and Recreation, "Priority development projects include trails, campgrounds, picnic areas, natural areas and cultural areas for recreational use." There is a 50\% matching minimum, and although historical project sizes have been around $\$ 300,000$, projects up to $\$ 4.1$ million have been funded. Given the scope of mitigation and restoration efforts considered within the Salton Sea, it was assumed that only larger projects would be pursued under this Fund. Therefore, the average grant size was assumed as the minimum value, with a maximum range of $\$ 1$ million. The maximum range appears to be unlikely as a reliable annual payment, but given the significant mitigation and restoration needs of the region, it may be possible to identify a series of discrete projects, or phases of projects, that would meet the Fund's requirements.

\subsection{Public Lands Renewable Energy Development Act of 2015 (S.1407 - $114^{\text {th }}$ Congress)}

This bill, introduced in 2015, proposes to amend the revenue distribution for solar and wind energy authorizations to include distributions to states and counties. This bill would provide for the distribution of bonus bids, royalties, rentals, fees, and other payments as follows:

- $35 \%$ - Renewable Energy Resource Conservation Fund (increasing to 40\% after 2030)

- $25 \%$ - County where the project is sited

- $25 \%$ - State where the project is sited

- $15 \%$ - BLM State offices for administration purposes (declining to $10 \%$ after 2030).

The bill calls for the Secretary of the Interior and the Secretary of Agriculture to establish a royalty level that would encourage production of solar or wind energy, ensure a fair return for the use of public lands, and encourage maximum energy generation within the areas' environmental constraints. As of the writing of this report, the bill had been introduced into the Senate on $5 / 20 / 2015^{72}$

\subsection{Water Quality, Supply, and Infrastructure Improvement Act of 2014 (Assembly Bill 1471)}

Based on the existing approved funding, it appears that some portion of $\$ 475$ million in funds approved from the California Water Bond (Proposition 1) may be available for various state obligations, including Salton Sea restoration work. ${ }^{73}$ Within AB1471, this funding is specifically allocated for "Quantification Settlement Agreement (QSA), including Restoration of the Salton Sea," which may imply that additional liabilities included under the QSA could reduce the total funding allocated to Salton Sea restoration work. \$200 million in funds for Salton Sea restoration was assumed as an upper limit, given the presence of other liabilities within the water bond.

\footnotetext{
${ }^{72}$ https://www.congress.gov/bill/113th-congress/house-bill/596

${ }^{73} \mathrm{http} / / /$ www.leginfo.ca.gov/pub/13-14/bill/asm/ab 1451-1500/ab 1471 cfa $20140812 \quad 174138$ sen floor.html http://awpw.assembly.ca.gov/sites/awpw.assembly.ca.gov/files/Corrected\%20Prop. $\% 201 \% 20$ Fact $\% 20$ Sheet.pdf
} 


\subsection{Existing and Proposed Royalty Payment Structures}

Under existing policy, and based on discussion with contacts at BLM, there are currently no revenues of any kind from solar or wind energy authorizations on the public lands that go to States or counties. Solar and wind energy authorizations are land use authorizations under FLPMA, and are not like mineral leases that are issued under other authorities (Mineral Leasing Act and Coal Leasing Amendments Act). All revenues of any kind go to Treasury, including: lease rents, SEZ bid auction proceeds, and solar and wind energy ROW revenue receipts (acreage fee and MW capacity fee). Therefore, barring future policy changes, such as HR 596, the focus of this analysis will be on geothermal royalty structures, of which $50 \%$ of the proceeds are currently shared with the state.

\subsubsection{Geothermal Royalty Structures}

A potential source of funding for restoration efforts is the payments associated with developing and producing renewable energy on Federal land in the counties surrounding the Salton Sea. The current royalty payment structure for renewable energy resources on Federal land in the United States (with the exception of Alaska) is split between the U.S. Treasury and the state with $40 \%$ of the state share directed back to the county of origin. For example, if current East Mesa geothermal leases generate $\$ 100,000$ in royalties, $\$ 50,000$ will be returned to the State of California, and of this, $\$ 20,000$ would go to Imperial County.

The royalty amount is not based on the value of the electricity sold to the utility. Rather, the current leases are all set at $10 \%$ of the value of steam, hot water, or other form of heat energy derived from the production of geothermal resources from the leases under what is called the Netback Method. This procedure derives the value of the geothermal resource by subtracting the lessee's costs of generating and transmitting electricity from the lessee's revenue resource upon which royalty is due. Through the provisions of the Netback Method established under 30 CFR 206.352 , the lessee is allowed to deduct up to $99 \%$ of the royalty value upon which the $10 \%$ royalty rate is applied. This means that lessees are currently permitted to reduce $\$ 1$ million of electricity down to $\$ 10,000$, and then apply the $10 \%$ royalty rate to end up at a royalty payment of $\$ 1,000$. However, the regulations for calculating royalties under the Netback Method were changed to a percent of gross proceeds under the Energy Policy Act of 2005 (EPAct 2005). So, for all leases issued after the passage of the EPAct 2005, there is a required $1.75 \%$ royalty rate of the gross proceeds for the first ten years of production, which increases to $3.75 \%$ after that.

The term of existing geothermal leases is 10 years with two optional 5-year extension periods, followed by one, final 5-year period if drilling has commenced before the end of the second 5year extension. Beyond the royalty structure described above, annual rents per acre are also paid on competitive and non-competitive leases. For the former, the annual rental is $\$ 2$ per acre in the first year, $\$ 3$ per acre in years 2 to 10 , and $\$ 5$ per acre during the extensions. For the latter, annual rentals are now the same, but prior to EPAct 2005, they were $\$ 1$ in years 1 through 10 . These rents must always be paid, but the EPAct 2005 language allows for rents to be deducted from the $1.75 \%$ royalty rate of gross proceeds for the first ten years of production. So, while the royalty and rent payment structures differ based on various factors, including timing and legislation, both royalties and rents must be paid once production begins. 


\subsubsection{Mineral Leasing Receipts}

Another potential source of funding is mineral leasing receipts from energy development. The most important factor at play with mineral leasing is the type of land where the energy development is occurring. On Federal land, the current structure under the Mineral Leasing Act of 1920 has $49 \%$ of mineral leasing receipts going to the state of origin. The only state where this is not the case is Alaska, which receives $88.2 \%$ of mineral leasing receipts. The other $51 \%$ of mineral leasing receipts goes to the Reclamation Fund (40\%) and U.S. Treasury General Fund (11\%). In 2014, California received $\$ 90.8$ million in mineral leasing receipts. It is currently up to the state to decide how the funds are allocated. On other types of land, such as state-owned land, the division of mineral receipts is up to the State of California and any applicable legislation.

One potential option for increasing the total mineral leasing receipts could be to petition the Federal government to receive $88.2 \%$ instead of $49 \%$ of receipts. This could result in substantial additional revenues; for example, if $\$ 90.8$ million is $49 \%$ of $\$ 185.3$ million in mineral leasing receipts, then $88.2 \%$ would be $\$ 163.4$ million. The State of California could then dedicate some portion of the increased receipts to Salton Sea restoration efforts.

There is also a Federal payment program called Payments in Lieu of Taxes, which is administered by the U.S. Department of the Interior. In 2014, California received $\$ 45.3$ million from this program, with $\$ 3.4$ million going to Imperial County and $\$ 3.3$ million going to Riverside County. While the funds are typically provided to cover local emergency services or education, they can be used for any governmental purpose, including restoration efforts. At minimum, some portion of payments in lieu of taxes (PILT) funds would likely be eligible to cover restoration efforts at the Salton Sea, as they are critical to the economic development and progress of the region. Also, some states have passed legislation to receive the entire PILT payment so they can determine the appropriate breakdown by county. Another mineral lease management option has been explored by Utah and Colorado, which have passed laws establishing Mineral Leasing Districts (MLDs) that administer all the funding received from receipts. This removes mineral leasing receipts from the PILT equation so the payment to a county with a MLD would be higher than a county without an MLD, all else being equal. There are additional strategies to maximize state and county payments, so both the State of California and the Salton Sea Authority should do a follow-on study that identifies any additional opportunities that are not currently being pursued.

\subsubsection{Future Steps}

With these two sources of funding, there are opportunities to potentially generate additional funding for restoration efforts. On payments associated with renewable energy development and production, the State of California could take several steps. The State of California could make efforts to pass more specific support mechanisms, including CA Senate Bill 1139, which requires $500 \mathrm{MW}$ of geothermal energy between 2015 and 2024. In addition, legislation specifically focused on encouraging development at the Salton Sea (streamlined environmental permitting) may also bolster renewable energy development in the region. 


\subsection{Transmission Revenues}

After incorporating assumptions from the previous study of renewable energy revenue potential (EES Consulting 2013), and assuming IID ownership of the transmission capacity, minimum transmission revenues available for Salton Sea redevelopment were estimated at $\$ 179,000$ to $\$ 357,000$ per year (500 kVDC monopole versus $500 \mathrm{kVDC}$ bipole). On a NPV basis, this amounts to between $\$ 2.2$ million and \$4.4 million from 2016 through 2045. Undiscounted, it amounts to between $\$ 5.4$ million and $\$ 10.7$ million.

\subsubsection{Transmission Capacity Build out Opportunity}

CAISO is currently exploring numerous transmission capacity additions to specifically address RPS compliance needs from Salton Sea renewable energy development, as well as the closure of the San Onofre Generating Station. It must be noted that these additional transmission projects were all characterized as facing challenging siting constraints of various severity. ${ }^{74}$

Based on discussion with IID, the IID has installed Path 42, increasing the thermal rating of the $\mathrm{KN} / \mathrm{KS}$ line to $1,400 \mathrm{MW}$ to $1,500 \mathrm{MW}$. Currently, roughly $75 \%$ of IID's Strategic Transmission Expansion Plan is fully permitted, and only requires ROW to still be purchased.

\subsection{Restoration Cost Reduction}

Based on data provided from the LADWP ${ }^{75}$, there are three quoted dust mitigation measures in terms of $\$($ millions $) /$ sq. mile. The dust mitigation measures discussed include gravel, saltgrass, shallow pond, and tillage, summarized in the table below:

Table 24. Dust Mitigation Summary

\begin{tabular}{|l|l|l|}
\hline Dust Mitigation Type & $\$($ Millions)/Sq. Mile & $\$ /$ Acre \\
\hline Gravel & 33 & $\$ 51,563$ \\
\hline Saltgrass & 15 & $\$ 23,438$ \\
\hline Shallow pond & 12.9 & $\$ 20,156$ \\
\hline Tillage & 1.29 & $\$ 2,016$ \\
\hline
\end{tabular}

(Source: Green 2014

The saltgrass and shallow pond methods also have significant water requirements, which may place an additional constraint on their deployment. As a conservative estimate of the value of any potential restoration cost reduction, from the perspective of establishing the minimum benefit of renewable energy project covering exposed playa, the tillage method assumption of \$2,016/acre will be used for this calculation.

Development on the future exposed playa will likely carry additional challenges for both the construction and the operations and maintenance (O\&M) of renewable energy projects. However, if the added value of playa coverage is monetized through a playa development incentive, or potentially even through the provision of exposed playa as freely developable land, the Salton Sea may be able to cover a portion of the exposed playa at a reduced cost.

\footnotetext{
${ }_{75}^{74}$ http://www.caiso.com/Documents/Presentation-ImperialCountyTransmissionConsulatation_Jul14_2014.pdf

${ }^{75}$ http://aridjournal.com/particulate-matters-emily-green/
} 
Under the first example, a one-time restoration benefit incentive of $\$ 1,000 /$ acre could be paid to any developer able to provide a durable, pre-approved dust mitigation measure (solar electric, geothermal, algae pond, renewable energy desalination, would be examples from the renewable energy sector, but other commercial purposes may also be applicable). Land-intensive technologies, such as algae or solar ponds, would benefit from a significant added revenue stream that could boost the project's economics, and the SSA would be able to fund dust mitigation efforts at a reduced rate.

Second, given the potentially significant costs associated with land acquisition and environmental permitting, offering pre-designated portions of unmitigated playa with reduced environmental permitting requirements could be an added economic incentive to development on the playa.

The benefit to development may still not outweigh the added complexity and cost to development of renewable energy projects on the playa. Additional detail from the LADWP Owens Lake solar PV project may provide additional certainty. Further study of the geotechnical soil conditions of the exposed playa, from a construction standpoint, would be required.

\subsubsection{The North American Development Bank}

The North American Development Bank (NADB) may be able to provide development expertise, as well as a lower cost of capital for both RE, desalination, and possibly even Salton Sea mitigation work. The NADB has a strong track record developing and financing numerous water and renewable energy-related projects. To date, 192 Border Environment Cooperation Commission-certified environmental infrastructure projects have been completed, worth roughly $\$ 2.25$ billion in loans and grants. To qualify, projects must be within $100 \mathrm{~km}$ to the north, which includes most of the Salton Sea Study Area (Figure 34).

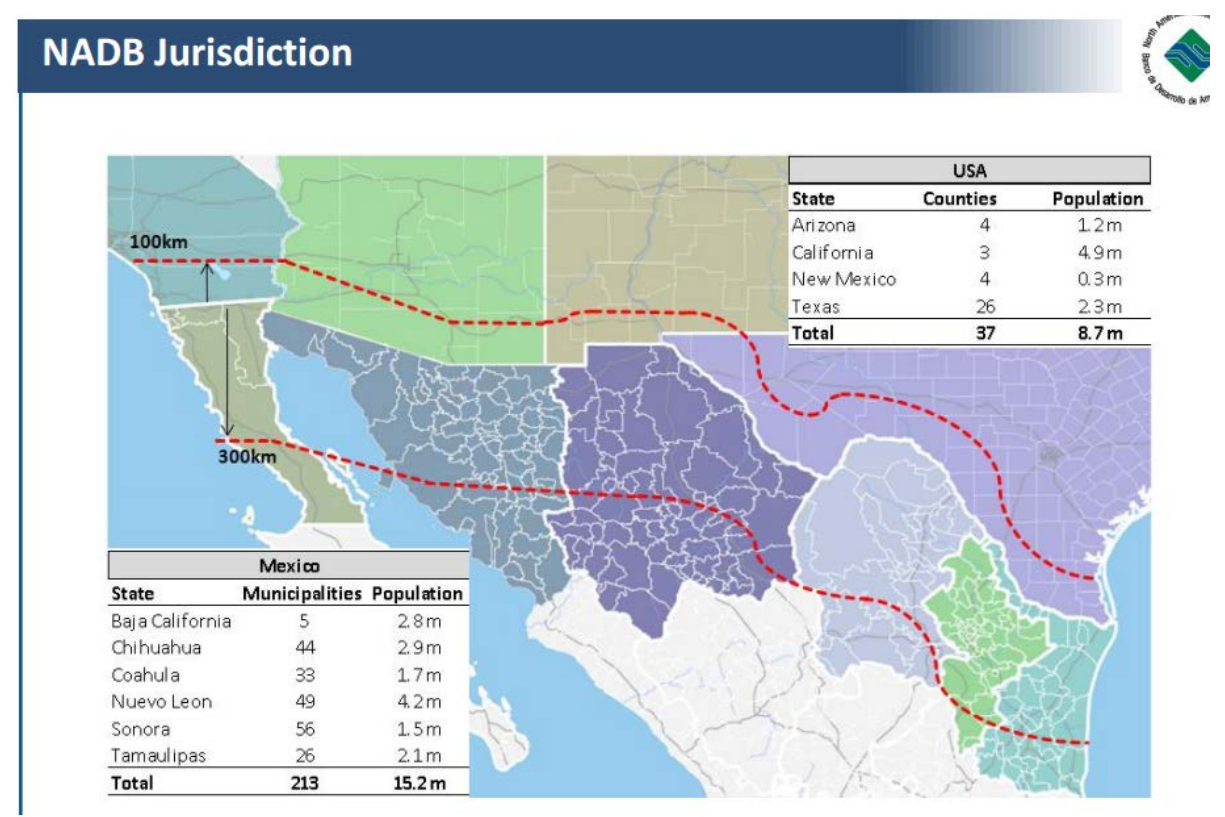

Figure 34. Qualified NADB assistance region. Image from North American Development Bank 
The benefits provided by the NADB are as follows:

- Loans. The NADB's maximum loan amount is the lesser of the following: $85 \%$ of the total project cost, or $\$ 182$ million for public sector projects and $\$ 110$ million for private. These loans may be up to 25 year term loans with fixed or floating rates. Although rates will vary significantly based on project details, a rough calculation using details from the NADB website indicates a potential cost of debt between $2.58 \%$ and $7.83 \%{ }^{76}$

- Technical Assistance. Support project development with closing financing, project design, etc.

- Grants. Mostly focused on community infrastructure and wastewater treatment. Fairly small grant sizes (\$2 million in CAP, $\sim \$ 7.6$ million in wastewater infrastructure).

Concerning eligible technologies, it appears that all major renewable energy technologies are eligible. Also notable is that desalination, water treatment, conservation and efficiency programs are also eligible. Finally, funding for "air quality" is available, which could potentially extend to dust mitigation work as well.

Several projects already completed in the Salton Sea area include: Ocotillo Wind (265 MW wind facility) and IVSC 1 (23 MW solar PV facility).

\section{Conclusions}

Of the commercially available renewable energy technologies, geothermal, solar PV, and CSP have the most significant technical potential for development. All of these technologies have large total resource potentials, but constraints, such as proximity to transmission access and regional cost-competitiveness of the power generated, may limit the economic potential. Based on extensive modeling within the CPUC calculator, it appears that any additional tax on generation for Salton Sea development would significantly disadvantage the development of these resources in comparison to other regions.

\subsection{Market}

The analysis conducted within Appendix B of the report supports the following overall conclusions about the market for Salton Sea renewables.

- Salton Sea renewables have no discernible headroom for bearing an additional cost earmarked for Salton Sea reclamation. Any added tax would need to reflect market conditions, as even the addition of a relatively small $\$ 5$ per MWh restoration charge to the cost of new Salton Sea geothermal projects could make them more expensive than $2 \%$ to $3 \%(14,000 \mathrm{GWh}$ to $21,000 \mathrm{GWh})$ of the competing California renewable energy supply pool. Similarly, a $\$ 5 / \mathrm{MWh}$ charge for solar would result in the area's best resources becoming more expensive than competing projects. As modeled in the RPS calculator, the area's resources would slip by about 7 percentage points in competitiveness in the California renewable energy supply pool, meaning that 49,000 GWh of competing projects would become economically superior. For context, the

\footnotetext{
${ }^{76}$ Commitment Fee $-0.075 \%$ on undisbursed loan balances Interest Rate (Treasury $+.025-150+0.04$ ). This is roughly $2.58 \%-7.83 \%$
} 
modeled incremental demand from increasing the 33\% California RPS to $50 \%$ may be between 44,000 GWh and 74,000 GWh.

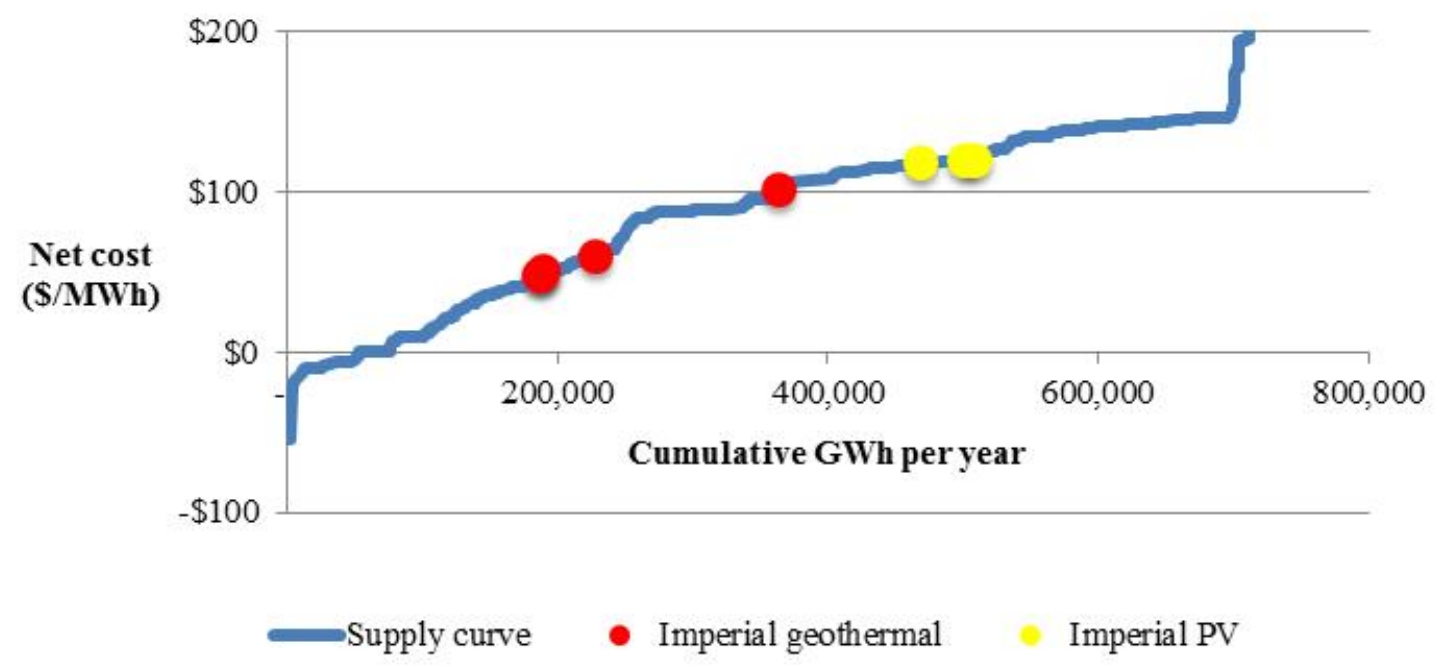

Source: CPUC RPS Calculator Figure 35: Net cost of potential new resources included in the RPS calculator (Point estimates of
the range of net costs.

- Both California and Arizona are likely to see higher demand for renewable resources in the Western Electricity Coordinating Council (WECC) region by 2020 and beyond. This demand is based on Integrated Resource Plans from the major California and Arizona utilities, and while it varies by utility, it primarily includes planned capacity from 2014 to 2024, with several plans extending through to 2034. This increase in demand will create opportunities for solar and geothermal located in the Salton Sea area, but power prices will need to be extremely competitive to compete with other regional low cost renewable resources. As an example, construction of the SunZia transmission line could lead to significant amounts of low cost wind becoming available from New Mexico.

- Salton Sea renewables will face different tradeoffs competing in the California and Arizona markets. While high power prices make the California market more lucrative, there are many choices for new renewable development. In Arizona, there are few practical alternatives to Salton Sea geothermal for renewable baseload, but power prices tend to be lower.

- Based on the Annual Technology Baseline, geothermal costs are not expected to change significantly from current levelized costs of energy between \$107/MWh and 131/MWh. The scale of solar PV and CSP cost reductions are uncertain, but are projected to range between $\$ 49$ and 94/MWh and $\$ 84$ and 132/MWh, respectively, by 2030. These costs are exclusive of tax credits and other potential state and local incentives.

\footnotetext{
${ }^{77}$ Net cost $=$ first-year PPA cost + transmission cost - market value of energy provided - capacity value
} 
- CAISO also conducted a limited information-only assessment of two recently proposed transmission projects (Midway-Devers $500 \mathrm{kV}$ AC line project and the Strategic Transmission Expansion Plan), and concluded that they might accommodate as much as 2,500 MW of additional renewable generation. Further, the construction of the HANG \#2 $500 \mathrm{kV}$ line could result in an additional $600 \mathrm{MW}$ to $700 \mathrm{MW}$ that could be exported to Arizona.

\subsection{Resource Confirmation}

The analysis conducted within the report supports the following overall conclusions about the technical potential for Salton Sea renewables.

Table 25. Summary of Developable Capacity by Technology in 2030

\begin{tabular}{|l|c|c|c|}
\hline Technology & $\begin{array}{l}\text { Total Potential (GW } \\
\text { unless otherwise } \\
\text { specified) }\end{array}$ & $\begin{array}{l}\text { Generation } \\
\text { Potential } \\
\text { (GWh/yr) }\end{array}$ & $\begin{array}{l}\text { Existing } \\
\text { Capacity } \\
\text { (GW unless } \\
\text { otherwise } \\
\text { specified) }\end{array}$ \\
\hline $\begin{array}{l}\text { Geothermal } \\
\text { (onshore) }\end{array}$ & $0.68-1.24$ & $4,765-8,690$ & 0.6 \\
\hline $\begin{array}{l}\text { Geothermal } \\
\text { (offshore) }\end{array}$ & $0.37-0.57$ & $2,593-3,995$ & 0 \\
\hline Solar PV & 1.8 & 3,672 & 5.87 \\
\hline CSP & 1.3 & 4,732 & 0.25 \\
\hline \begin{tabular}{l} 
SGSP \\
\hline $\begin{array}{l}\text { Brine Mineral } \\
\text { Recovery }\end{array}$
\end{tabular} & 0.1 & 788 & 0 \\
\hline $\begin{array}{l}\text { Algal Biofuels } \\
\text { (offshore) }\end{array}$ & $39,000-122,000 \mathrm{MT}$ Li & N/A & 0 \\
\hline $\begin{array}{l}\text { Algal Food } \\
\text { and Feed } \\
\text { (offshore) }\end{array}$ & 600,000 tons/year & N/A & 0 \\
\hline Daf Sous: Tabs & N/A & 0 \\
\hline
\end{tabular}

Data Sources: Tables 10 through 14 and Table 19 of this report.

- There is a most likely total developable geothermal capacity of 1,840 MW in the Salton Sea region. This excludes the current operational capacity of 602.1 MW.

- The Salton Sea KGRA comprises 1,350 MW of the most likely developable capacity, much of which is still underwater within the Salton Sea. Figure 36 shows the potentially developable amounts over time. Although there is strong technical potential for development of the offshore geothermal resource, additional foundation and drilling requirements associated with building on the playa may make development uneconomic (Figure 36). 


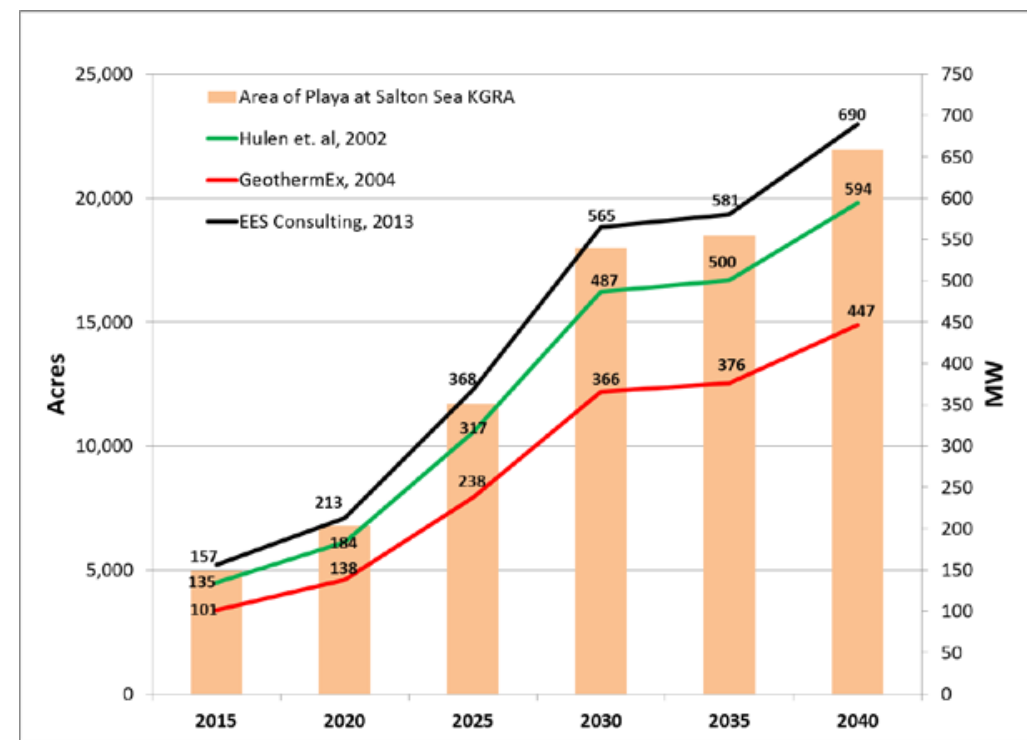

Figure 36. Potential development of offshore Salton Sea KGRA based on the shoreline recession in 25 years.

- Based on the modeled recession rates, the Salton Sea will recede most rapidly between 2020 and 2030, exposing roughly 30,000 acres of playa around the entire Salton Sea, of which approximately 11,000 acres will be exposed within the Salton Sea KGRA. The exposed land within the KGRA is potentially available for development for geothermal, and the remaining land may be suitable for solar PV, algal biomass, SGSP's, or for construction of wetlands/habitat. It should also be noted that the Salton Sea is expected to slightly reverse its recession between 2040 and 2050; this is due to the fact that as salinity increases, the evaporation rate decreases.

- Solar PV has the largest developable potential within 1 mile of $138 \mathrm{kV}$ to $230 \mathrm{kV}$ substation at $1.8 \mathrm{GW}$, followed by CSP at $1.3 \mathrm{GW}$. However, this region has a much larger technical potential of $31.9 \mathrm{GW}$ and $23.9 \mathrm{GW}$, respectively, within 5 miles of existing $138 \mathrm{kV}$ to $230 \mathrm{kV}$ transmission substations. This additional capacity could be available if larger projects are able to absorb the additional costs of long interties, or if future transmission expansions are constructed in the region. This region has a total potential of $107 \mathrm{GW}$ and $77 \mathrm{GW}$, respectively, although this would involve development of all available land, and is only included as an upper limit.

\subsection{Potential Revenues from Renewable Energy Development}

Based on the memo of understanding between the IID, Imperial County, and the Imperial Air District, the parties have agreed to cooperate in the development of renewable energy sources and allocate the potential revenues towards the restoration efforts. The development of the renewable energy technologies examined within the report will generate local tax revenues, environmental mitigation fees, regional economic development from construction, geothermal royalty payments to the state and counties from development on BLM lands, and land lease revenues from development of IID-owned playa for Salton Sea development from power generation projects. 
A brief discussion of the potential revenues from each technology is summarized below; see Appendix $\mathrm{C}$ for full calculations:

\section{- Geothermal:}

- Royalty payments from geothermal projects developed on BLM land could generate $\$ 1$ million to $\$ 3$ million annually for Salton Sea restoration efforts. This is assuming the full $.68 \mathrm{GW}$ to $1.24 \mathrm{GW}$ of capacity is developed on BLM land and a range of PPA prices between $\$ 80 \mathrm{MWh}$ and $\$ 100 \mathrm{MWh}$. The current total capacity developed on BLM land in the region is $80.1 \mathrm{MW}$ at the East Mesa KGRA, so the quantity of BLM land that will be developed in the future is still uncertain.

- The low and high land lease revenues for offshore projects on IID-owned playa were estimated at \$6 million to \$12 million annually, assuming that the estimated playa recession and developable offshore potential by 2030 are realized.

- Solar:

- The low and high land lease revenues for onshore PV projects were estimated at $\$ 1.5$ to $\$ 4.4$ million, and assume the development of $1.8 \mathrm{GW}$ of capacity within the BLM SEZ's, as well as the passage of HR 596, which would allocate BLM royalties from development back to the county and state.

- An additional potential revenue stream from development of solar photovoltaics on the playa was considered, based on the following: an assumed 100\% share of royalties for offshore IID projects, full development of the non-KGRA land within the playa exposed by 2030 , and PPA prices between $\$ 60-\$ 80 / \mathrm{MWh}$. The total non-KGRA land within the playa, within 5 miles of a $138 \mathrm{kV}$ to $230 \mathrm{kV}$ substation, was 9,938 acres. A 7.9 acre/MW land use factor was applied to this acreage to determine the estimated capacity of $1.25 \mathrm{GW}$, and the production factor listed below in Table 11 was applied to this capacity. IID leases were assumed to range between $1-2 \%$ of gross proceeds. The low and high values for the estimated offshore IID land PV projects were \$1 million to \$3 million annually, assuming that the estimated playa recession and full development of the non-KGRA playa acreage by 2030 is realized. This $1.25 \mathrm{GW}$ potential is not included in the likely developable solar capacity of $1.8 \mathrm{GW}$, due to the remaining uncertainty surrounding the feasibility of large-scale PV development on the Salton Sea playa.

- Brine Mineral Recovery. Potential revenues from lithium production could reach up to \$25.8 million annually. However, the feasible taxable percentage of gross proceeds will be heavily dependent on the operating costs of the mineral recovery project. In general, technology is available for removal of most of the minerals mentioned above; however, the economics of deploying the technologies are marginal at this time, either due to the high cost of the extraction technology or to the market price of the mineral not being adequate.

- Algae. Although algal biofuel development appears to be technically viable in the region, this technology is currently pre-commercial and is unlikely to be cost-competitive in the 
next 5 to 10 years. If algal biofuels reach $\$ 3$ /gallon cost competitiveness by 2030 , between $\$ 1.2$ to 2.3 million in potential mitigation revenues might be realizable, based on a 1-2\% lease rate on gross proceeds. The Salton Sea appears to be a favorable region for development of algal biomass resources, due to the presence of highly saline water, large tracts of unused playa and high insolation.

- Desalination. Desalination from renewable energy could provide a significant potential benefit for Salton Sea restoration efforts by feeding desalinated water back into the Sea and addressing the increasing salinity problem directly. Although this method is technically feasible, returning fresh water to the Sea at zero or near-zero cost requires an alternative source of revenue for the process, such as salt sales. However, a strategy based on revenue from salt sales assumes that there is a developer with sufficient capital and technical expertise to execute on this type of integrated project, and several assumptions included in this high-level estimate may not materialize, such as the availability of a sufficient market price for salt, or an acceptable performance of the system at scale.

- Hydrogen. The Salton Sea region has significant potential to produce renewable hydrogen relative to other parts of the United States, and is 150 miles from Los Angeles, which is expected to be largest market for FCEVs. However, it does not appear that the Salton Sea region would be able to achieve the scale required for economic transportation until beyond 2030.

\section{Observations}

The results of this study support the following observations:

- The inclusion of any additional production tax on renewable power generation is likely to make renewable energy projects in the study area less attractive in comparison to neighboring regions. Both California and Arizona are likely to see higher demand for renewable resources in the WECC region by 2020 and beyond, but it appears that even a small additional tax of \$5/MWh on generation for Salton Sea development would significantly disadvantage the development of these resources in comparison to other regions. While the magnitude of developable resources within the Salton Sea area is significant, this is also an indicator of the high level of competition that upcoming renewable energy projects will face when competing for space within a limited supply pool. Potential developments that could affect these findings include the implementation of more aggressive in-state renewable energy capacity goals, and additional project cost declines uniquely benefitting the Salton Sea region (i.e., local incentives, exceptional transmission access).

- There could be potential additional economic headroom for a $\$ 1 / \mathrm{MWh}$ to $\$ 5 / \mathrm{MWh}$ production tax if policies favorable to renewable energy create a unique benefit to development within the region. These policies could include utilizing the North American Development Bank for development expertise and to leverage interest rate cost savings, streamlining permitting requirements, and providing certainty surrounding environmental permitting costs.

- Legislative change from the Public Lands Renewable Energy Development Act could result in county revenues from solar development that could be allocated to Salton Sea 
Restoration efforts. Under the existing payment structures, no BLM revenues from solar or wind development are distributed to the state or county, although this introduced legislation proposes to allocate $50 \%$ of competitive solar and wind lease revenues to the state and county.

- Salton Sea geothermal appears to be within a fairly competitive position on the total supply curve, especially when its additional value as a baseload renewable energy source is considered. In the near term, development of future geothermal resources will likely be constrained by PPA pricing, but could become more competitive as higher penetrations of renewable generation are reached in the California and Arizona market, and baseload renewable power becomes more valuable. Continuing to actively monitor the need for additional transmission capacity will ensure that the development of otherwise competitive projects is not constrained.

- Further analysis is required to refine estimates of the developable geothermal potential on the playa. The developable offshore potential is based on the percentage of playa exposed within the estimated bounds of the reservoir, but more accurate estimates can be achieved through volumetric assessment of the offshore resource. Further study of the geotechnical soil conditions of the exposed playa, from a construction standpoint, would also be required to refine offshore geothermal cost estimates.

- Although salinity-gradient solar ponds have not been established as an economically viable power production technology to date, the ability of this technology to provide an additional value stream (low-grade heat or electricity) while also covering large areas of exposed playa may make it suitable for development at the Salton Sea. Further analysis of the economic viability (Ability to secure construction financing and power purchase agreement), as well as the detailed investigation of the technical potential for synergy between this technology and algae development or desalination will be required to determine if a commercial-scale plant would be feasible in the region.

- Geothermal brine mineral recovery requires updated well data for more precise estimates of the recoverable potential. Well variability, both in terms of flow rate and lithium concentrations, is another significant obstacle to successful geothermal brine mineral recovery development, as future revenue from mineral recovery will depend heavily on successful geothermal exploration efforts.

- It appears that thermal desalination, and in particular, multi-effect distillation are especially suited for the region. This is based on the high TDS content of the Salton Sea surface water, as well as on the presence of low-grade geothermal and abundant solar resources. Low-temperature geothermal brine or solar thermal collectors such as flat plate collectors or solar ponds may be an ideal heat source, as they are lower cost and may cover additional exposed playa.

- Although the technology for algal biofuel production has not yet reached the commercial stage of development, commercialization is expected within the next 15 years. Due to the presence of highly favorable conditions, such as saline water, large tracts of unused playa, and high insolation, the Salton Sea could produce up to 40 million gallons of algal biofuel per year. Algal biomass development could potentially cover large tracts of exposed playa, absorb a portion of existing irrigation fertilizer runoff, and generate an 
additional revenue stream from the sale of co-products, such as nutritional supplements like spirulina or beta carotene. Further study of the Salton Sea's water quality is required, but development of an algal biomass pilot plant on exposed Salton Sea playa could verify whether this proposed renewable energy restoration mechanism is viable. NREL has discussed this proposed mechanism with two organizations currently exploring pilot studies at this location, UCSD and Synthetic Genomics, Inc., which operates an R\&D facility next to the Salton Sea.

- Renewable hydrogen production for fuel cell electric vehicles in the Salton Sea is not economically viable in the short-term; however, there is existing demand for hydrogen in the Los Angeles region from both crude petroleum refineries and the developing hydrogen transportation sector. The Salton Sea region may be able to provide renewable hydrogen for refineries, in order to reduce the carbon footprint of petroleum fuels and products (e.g. plastics). This market could be a viable near-term (2018-2020) path to commercialization for renewable hydrogen. Further study of the likely demand within this market, as well as the region's economic competitiveness for this opportunity, is required. Additional near-term potential markets for hydrogen include its use as a power plant fuel. If viable, serving any of these existing markets may advantageously position the region to meet future renewable hydrogen transportation demand.

- Due to ongoing significant changes in federal regulatory policies, increasing state RPS goals, shifts in technology costs and adoption, and accelerated plant retirements, further study of the power system in the U.S. West is required. A variety of models and tools exist that can be utilized to assess the opportunities and challenges. The NREL Resource Planning Model (RPM) model develops future scenarios of the market potential and transmission needs of different renewable and non-renewable options in the Western Interconnection, and at high spatial resolution for particular focus regions, such as Southern California. NREL also employs the PLEXOS production cost model to assess the operational impacts - including renewable curtailment, plant operational flexibility, transmission congestion, changing electricity imports and exports - under future infrastructure conditions. PLEXOS can be similarly employed to evaluate generating capacity and transmission scenarios in Southern California. 


\section{Appendix A: Technology Status Updates}

This section reports on technology updates on the commercial status and prospects of geothermal energy systems solar power systems and algal biofuel production.

\section{Geothermal Energy Systems}

Utilization of geothermal energy comes in two primary forms: power generation and direct use.

\section{Power Generation Technologies}

Geothermal power plants come in three forms: dry steam, flash, and binary cycle. The type of plant deployed depends on resource temperature, and to some extent, developer preference.

\section{Dry Steam}

Dry steam plants are the oldest geothermal power plant type, first deployed at Lardarello in Italy in 1904. They are the simplest form of geothermal power plant. The plants draw steam from underground reservoirs directly into the turbine/generator unit (Figure A1) (GEO 2005). Emissions from dry steam plants are excess steam and very minor amounts of gases.

Resource temperature requirements for dry steam plants are high due to the need for steam to be present in the reservoir. Additionally, a geologic cap must be present above the reservoir in order to trap the steam in the subsurface. Because of this there are very few examples of steam reservoirs in the world and there are only two known underground resources of steam in the United States: the Geysers in northern California and Yellowstone National Park in Wyoming.

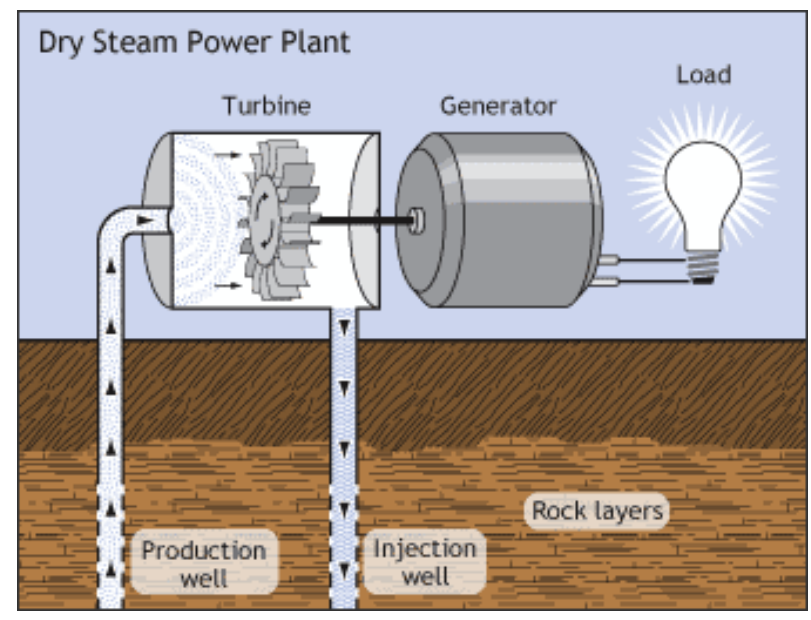

Figure A1. Schematic of a dry steam power plant. Illustration from Geothermal Energy Association

\section{Flash Steam}

Flash steam plants also utilize steam, but not directly from the reservoir (Figure A2). Geothermal brine flows up through a well under its own pressure (Kagel 2008). As it flows upward, the pressure decreases and some of the hot water boils into steam (this can also be accomplished in a "flash" tank at the surface). The steam is then separated from the water and passed through a turbine/generator unit. Any leftover water and condensed steam are injected back into the reservoir, making this a sustainable resource. 


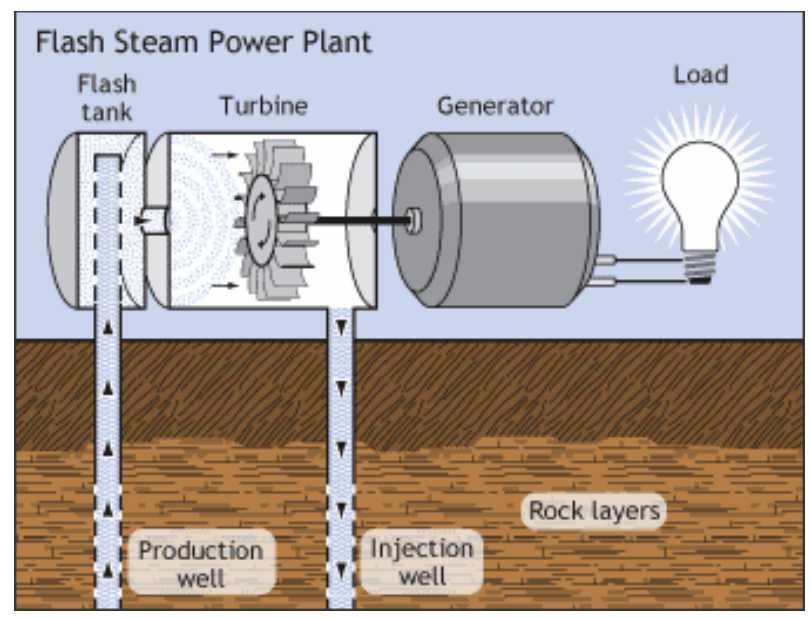

Figure A2. Schematic of a flash steam power plant. Illustration from Geothermal Energy Association

A common variation of the flash steam plant is the dual/double flash steam plant. In a double flash plant an additional flash tank is added after the primary (high pressure) turbine/generator unit(s) and the condensed steam (sometimes augmented with low pressure geothermal brine) is flashed again to turn a secondary (low pressure) turbine/generator unit.

Geothermal resource temperatures in excess of $360^{\circ} \mathrm{F}\left(182^{\circ} \mathrm{C}\right)$ can be used in flash plants to make electricity. Currently, flash plants are the most common form of geothermal power plants deployed in the U.S.; however, as development shifts to lower temperature geothermal resources, the trend is toward binary cycle power plants.

\section{Binary Cycle}

Binary cycle power plants do not flash the geothermal brine, instead the brine is used to flash a working/secondary (i.e., binary) fluid with a much lower boiling point (Kagel 2008). To accomplish this, a heat exchanger is used to transfer heat from the geothermal brine to the working fluid (Figure A3) (GEO 2005). Heat from the geothermal fluid causes the secondary fluid to flash to vapor, which then drives the turbine/generator unit(s). The organic rankine cycle binary power plant is the most commonly deployed version today and its commercial viability is well established. 


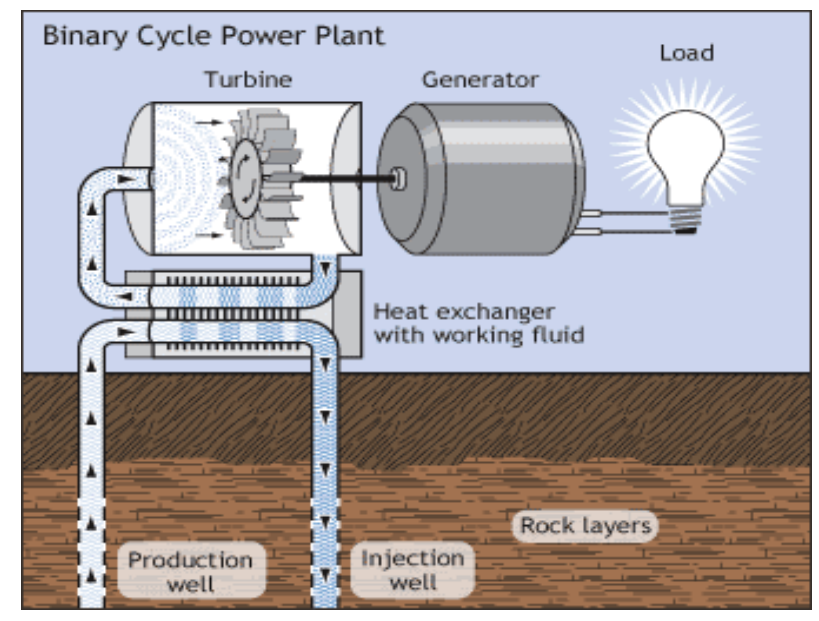

Figure A3. Schematic of a binary cycle power plant. Illustration from Geothermal Energy Association

Binary cycle power plants operate on water at lower temperatures of between $225^{\circ} \mathrm{F}$ and $360^{\circ} \mathrm{F}$ (in some cases lower brine temperatures can be used if the plant is water cooled). These types of plants have little to no emissions due to the physical separation of the geothermal brine and the working fluid during the process, making it a closed-loop system.

\section{Advanced Technologies}

There have been a number of industry advancements in recent years in geothermal power plant engineering, including:

- Hybrid Flash/Binary Combined Cycle. In this type of plant (Figure A4) (Bronicki 1995), the portion of the geothermal water which "flashes" to steam under reduced pressure is first converted to electricity with a backpressure steam turbine and the low-pressure steam exiting the backpressure turbine is condensed in a binary system (Kagel 2008). This can be a more effective use of the geothermal brine and take advantage of the benefits of both technologies. An example is the Puna Geothermal Power plant in Puna, Hawaii.

- Triple Flash Steam Plants. Yet another variation of the flash steam plant is separating the steam into three pressure streams instead of two. An example of this technology is the Hudson Ranch Plant near the Salton Sea (Geothermal 2013).

- Mixed Working Fluid System. The thermal efficiency of binary power plants is low compared to dry or flash steam plants; however, much research on advanced working fluids is currently under way to improve this efficiency. One such type is the Kalina cycle, which uses water and ammonia as the working fluid to improve efficiency (Kalina 2006). There are other possible mixed working fluid approaches to achieve higher efficiencies and/or lower temperature production of power.

- Hybrid Cooling. For air-cooled geothermal power plants, adequate cooling, especially in hot and dry climates, can be very difficult to achieve. In many cases, plant output can be diminished by up to $50 \%$ during the hottest days of summer. Research conducted by NREL has examined the effects of cooling the air with a fine mist before it enters the 
condenser, with promising results of increased power while using much less water than conventional water cooled systems (Ashwood and Bharathan 2011).

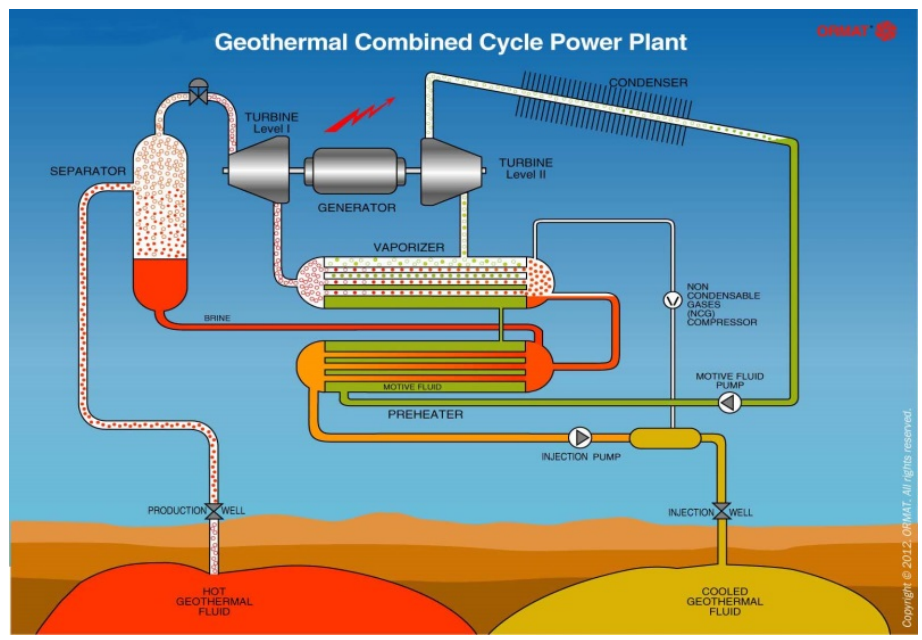

Figure A4. Flash/binary combined cycle plant. Illustration from Geothermal Energy Association Cost

Costs associated with geothermal power plant development include: exploration and permitting, well field development, power plant and cooling type (binary vs. flash, dry vs. wet), and other supporting infrastructure (i.e., pipelines, transmission, and roads). Table A1 shows a typical breakdown of costs and time for each development phase.

Table A1. Geothermal Project Development Cost Breakdown and Timing

\begin{tabular}{|c|c|c|c|}
\hline Phase & Activity & $\begin{array}{c}\text { Cost } \\
\text { (\% Total) }\end{array}$ & $\begin{array}{c}\text { Time } \\
\text { (years) }\end{array}$ \\
\hline \multirow{2}{*}{$\begin{array}{l}\text { Resource } \\
\text { Exploration } \\
\text { and } \\
\text { Evaluation } \\
\end{array}$} & Exploration & $0.2-0.5 \%$ & \multirow[b]{2}{*}{$1-2$ years } \\
\hline & Permitting & $1-4 \%$ & \\
\hline $\begin{array}{l}\text { Exploration } \\
\text { Drilling }\end{array}$ & $\begin{array}{l}\text { Exploratory } \\
\text { Drilling }\end{array}$ & $4-6 \%$ & 1 year \\
\hline \multirow{2}{*}{$\begin{array}{l}\text { Resource } \\
\text { Development }\end{array}$} & $\begin{array}{l}\text { Production } \\
\text { Drilling }\end{array}$ & $35-40 \%$ & \multirow{2}{*}{$1-2$ years } \\
\hline & $\begin{array}{l}\text { Steam } \\
\text { Gathering }\end{array}$ & $6-8 \%$ & \\
\hline \multirow{2}{*}{$\begin{array}{l}\text { Plant } \\
\text { Construction }\end{array}$} & $\begin{array}{l}\text { Plant } \\
\text { Construction }\end{array}$ & $45-50 \%$ & \multirow{2}{*}{ 1-2 years } \\
\hline & Transmission & $2-4 \%$ & \\
\hline & & Total & 5-7 years \\
\hline
\end{tabular}

The costs of developing a geothermal system are heavily weighted toward early expenses, rather than the costs of keeping them running. Well drilling and pipeline construction occurs first, followed by resource analysis of the drilling information. Next is design of the actual plant. 
Power plant construction is usually completed concurrent with final field development. Based on the NREL Annual Technology Baseline ${ }^{78}$, the initial cost for the field and a binary power plant is $\sim \$ 6,811$ to $\$ 7,442$ per installed $\mathrm{kW}$ in the United States. Flash plants are less costly at $\$ 6,487$ to $\$ 7,088$ per installed $\mathrm{kW} .{ }^{79}$ Operating and maintenance costs range from $\$ 216$ to $\$ 368$ per

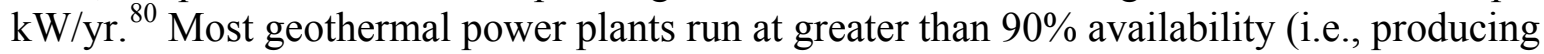
electricity more than $90 \%$ of the time). The world average geothermal plant capacity factor is $75 \%$. Table A2 summarizes typical geothermal investment costs, operating and maintenance costs, and capacity factors.

Geothermal development in the Salton Sea is expected to cost somewhat more than average due to engineering costs related to managing geothermal brine chemistry (possibly offset by mineral extraction), environmental costs, and higher drilling costs in the event resources are developed with directional drilling beneath the sea and playa. Although it does appear that development of geothermal projects on the playa will be technically viable, based on discussions with one geothermal developer, preliminary estimates are that these offshore geothermal costs could potentially be $10 \%$ higher than onshore geothermal construction due to additional foundation requirements.

Geothermal costs are not expected to decline significantly by 2030, and have been assumed to be stable in the modeled cost trajectories of the Annual Technology Baseline report. As O\&M costs appear to be elevated in the Salton Sea region as well, these estimates were developed based on discussions with two separate sources, a developer within the geothermal industry, as well as the NREL RPM cost modeling team.

Table A2. Representative Current Utility-Scale Geothermal Costs (2015)

\begin{tabular}{|l|c|c|c|}
\hline Technology & $\begin{array}{c}\text { Capacity } \\
\text { Factor }\end{array}$ & $\begin{array}{c}\text { Total Capital } \\
\text { Req'd } \mathbf{( \$ / k W})^{*}\end{array}$ & $\begin{array}{c}\text { Fixed O\&M } \\
(\$ / k W-y r)\end{array}$ \\
\hline Binary Plant & $80 \%$ & $6,811-7,442$ & $216-236$ \\
\hline Flash Plant & $94 \%$ & $6,487-7,088$ & $337-368$ \\
\hline
\end{tabular}

Does not include production tax credits, investment tax credits, loan guarantees or other incentive programs.

Source: NREL ATB

\section{Geothermal Direct-Use Technologies}

Direct-use geothermal systems are simple in design, consisting of a well field (production and injection wells, and submersible pumps), distribution piping (in-line pumps), and heat exchangers (to transfer heat from the pipeline to the application (Figure A5) (Canadian 2014). The direct-use applications (i.e., the demand side of the system) can, however, be complex and involved.

\footnotetext{
${ }^{78}$ NREL, Annual Technology Baseline and Standard Scenarios (web page, http://www.nrel.gov/analysis/data_tech_baseline.html).

${ }^{79}$ US DOE Geothermal Energy Technology Evaluation Model (GETEM). http://www4.eere.energy. gov/geothermal/projects/1096 and http://www4.eere.energy.gov/geothermal/sites/default/files/documents/mines_getem_peer2013. pdf.

${ }^{80}$ Discussion with industry
} 


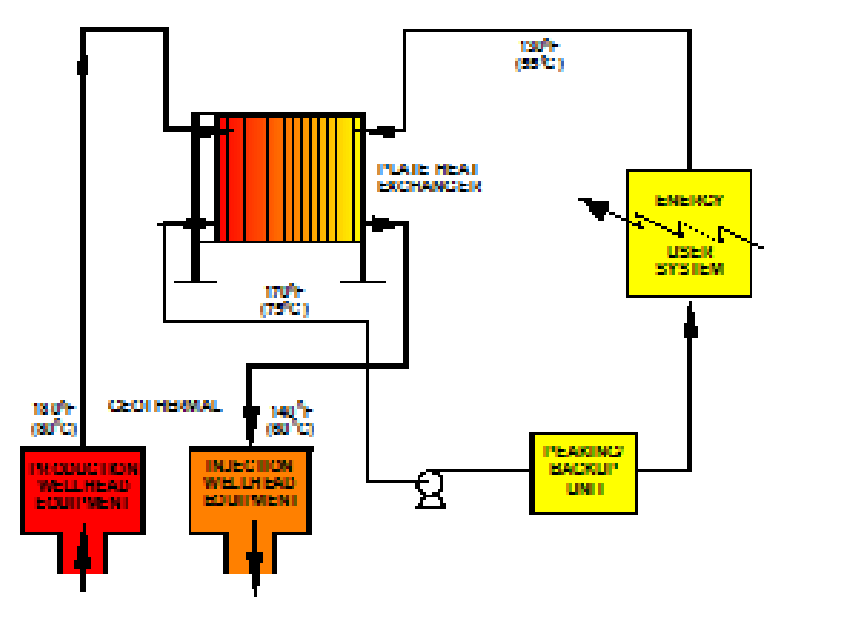

Figure A5. Typical direct-use geothermal heating system configuration. Illustration from Geothermal Energy Association

For the Imperial Valley, direct use applications would be worth considering for resource temperatures below those needed to achieve utility-scale power generation (here assumed to be $<300^{\circ} \mathrm{F}$ ). There are many direct-use applications (Figure A6) that fall into four broad categories (CanGEA 2014):

- Balneology (spas)

- Space heating (and cooling)

- Food growth and processing (aquaculture and agriculture)

- Industrial.

Based on what is known about the local geothermal resource, climate, and potential utilization needs, the most likely applications are food processing and industrial in nature. 


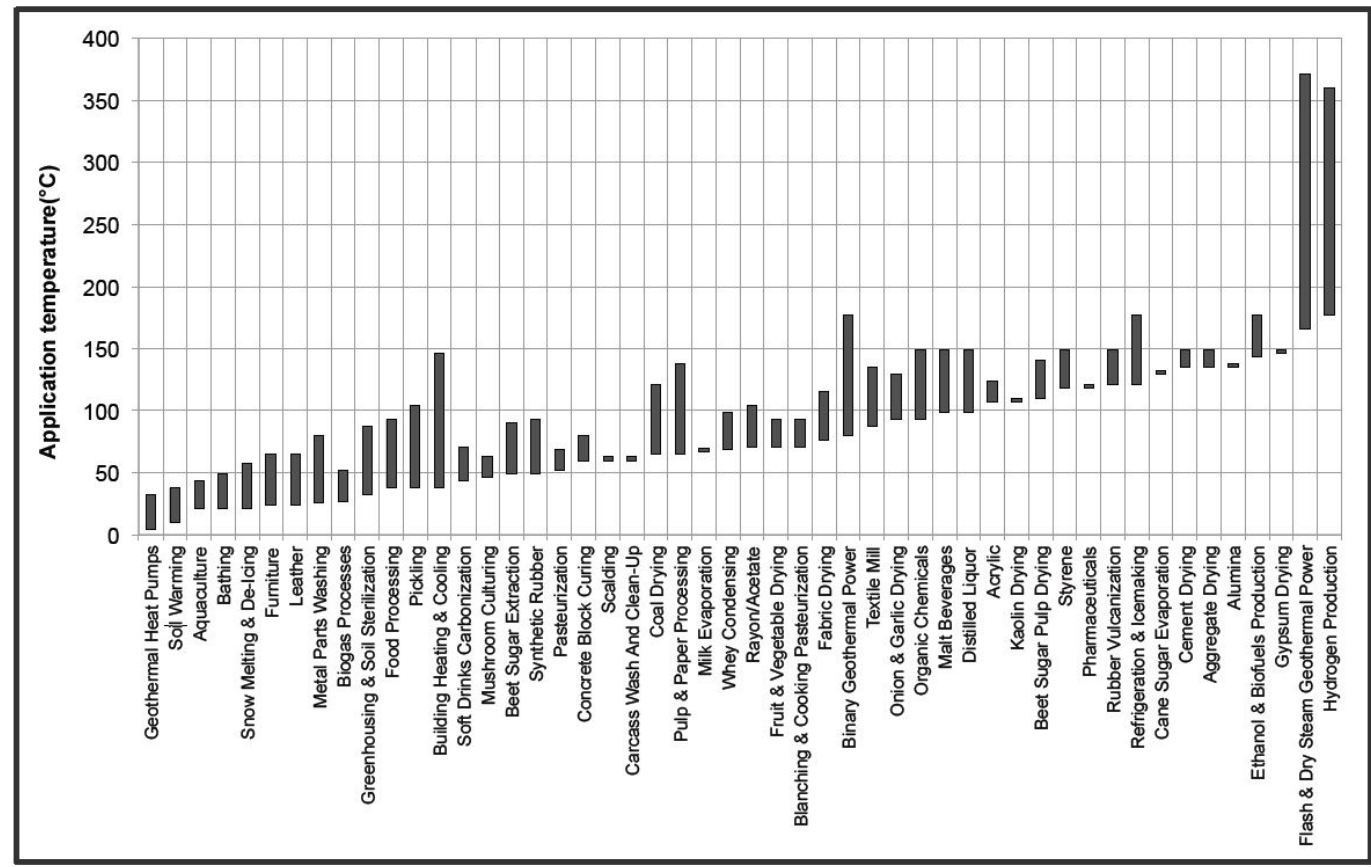

Source: CanGEA 2014

Figure A6. List of direct-use applications by temperature

The development of any direct-use system is costly, with most of the cost (50\% to $70 \%)$ being sunk into the well field and the rest into the distribution system. Potential ways to mitigate the costs (to some extent) include:

- Using abandoned wells with adequate temperature and flow rate for direct-use application(s), but not power production

- Using the effluent (outlet) brine from an existing power plant

- Developing a cascaded geothermal system (Figure A7) (Canadian 2014) that combines as many geothermal applications as the system can support (this could be combined with 1 or 2 additional applications to further reduce costs). 


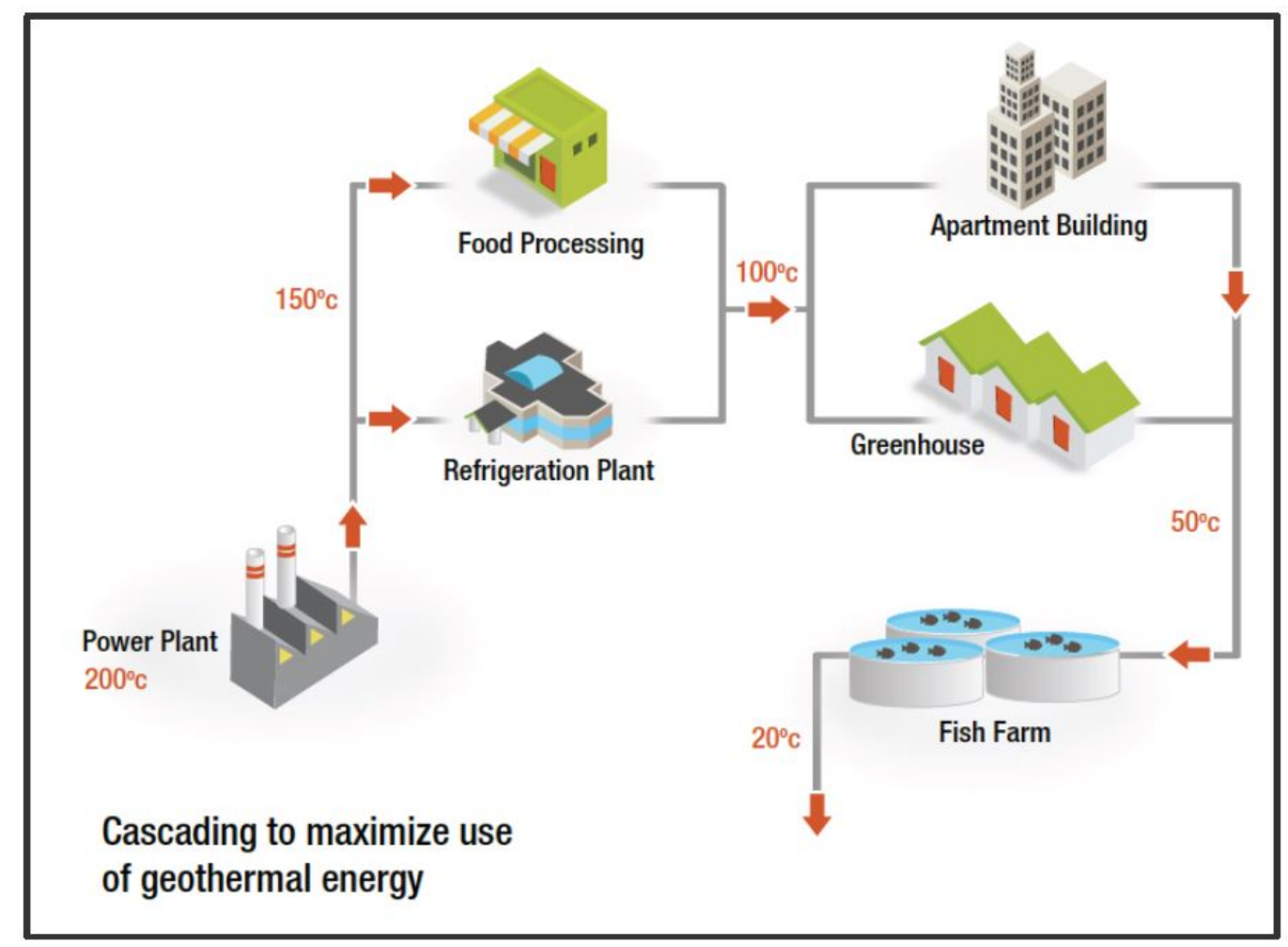

Source: Canadian 2014

Figure A7. Example of a cascading direct-use system with power production.

\section{Food Processing}

Development of geothermal resources for direct-use applications has mostly occurred in northern states where space heating demands are high. These are also areas that would benefit from extended season (or even year round) agriculture (i.e., greenhouses). The Imperial Valley is an agricultural district that could potentially benefit from food processing applications such as fruit/vegetable drying, pasteurization, etc.

\section{Industrial Processes}

A broader set of direct-use applications that may be of interest fall in the industrial process category. In particular, two applications - desalination and mineral recovery - may have broad applications in the Imperial Valley. Brief overviews are given here. See Section 4.1 for a more in-depth analysis on desalination and mineral recovery potential in the Salton Sea.

Desalination. The concept of combining geothermal and desalination has been discussed in the literature for quite some time (Bujakowski et al. 2010). The geothermal energy can be used to run a power plant and the electricity utilized by an electrically driven desalination technology such as reverse osmosis or mechanical vapor compression. Or, it can be used directly for thermally driven desalination process such as multi-effect distillation of thermal vapor compression. Desalination has the potential to be a large scale local off taker of electricity. There is also potential for desalination to be a heat user, where heat could be delivered by either a power plant operator or via the revitalization of abandoned geothermal wells. 
Mineral Recovery. There is strong interest in mineral recovery from geothermal brines. Recently the U.S. Department of Energy awarded up to $\$ 3$ million in funding to advance geothermal mineral recovery R\&D. ${ }^{81}$ Additionally, there is an active mineral extraction plant working in the Salton Sea area; as well as at least one other (extracting zinc) in the past. Simbol Minerals has an agreement with Energy Source to extract lithium from effluent (outlet) brine exiting the Featherstone Plant before it is re-injected back into the subsurface. The project is currently at a demonstration scale, with a goal of 15 metric tons of extracted lithium annually.

In addition to lithium, other minerals that could be recovered from geothermal brine include zinc, manganese, cesium, rubidium, silica, etc. (Boucier et al. 2003). Silica is found at high levels in geothermal brines of the Imperial Valley and removal of it could be very beneficial to the mineral extraction industry as well as power plant operators. This is because silica acts as an inhibitor to extraction of most other minerals and silica can cause extensive and damaging scaling to well cases, which results in higher power plant O\&M costs. There is a market for high purity silica; however, the cost to extract it and crystalize it in that form is marginal at this time.

In general, technology is available for removal of most of the minerals mentioned above; however, the economics of deploying the technologies are marginal at this time, either to the high cost of the extraction technology or the market price of the mineral not being adequate.

\section{Solar Power Systems}

Solar power systems are divided into technologies that directly convert sunlight into electricity (photovoltaics) and technologies that collect the sun's thermal energy. Solar thermal energy can be used directly for a variety of commercial and industrial purposes or can be converted into electricity via a thermo-electric power cycle. Solar thermal electric systems are known as CSP. Solar ponds are passive solar thermal collectors used for the production of low-grade heat for industrial processes or power production. The various technologies are listed in Table A3.

\footnotetext{
${ }^{81} \mathrm{http}$ //energy. gov/eere/geothermal/downloads/low-temperature-mineral-recovery-program-foa-selections.
} 
Table A3. Overview of Different Solar Technologies (NREL)

\begin{tabular}{|c|c|c|c|c|c|c|}
\hline & PV & $\begin{array}{c}\text { CSP } \\
\text { Parabolic } \\
\text { Trough }\end{array}$ & $\begin{array}{c}\text { CSP } \\
\text { Linear } \\
\text { Fresnel }\end{array}$ & $\begin{array}{l}\text { CSP } \\
\text { Power } \\
\text { Tower }\end{array}$ & $\begin{array}{c}\text { CSP } \\
\text { Dish / } \\
\text { Engine }\end{array}$ & $\begin{array}{l}\text { Solar } \\
\text { Pond }\end{array}$ \\
\hline Typical Operating Temp & ambient & $390^{\circ} \mathrm{C}$ & $450^{\circ} \mathrm{C}$ & $565^{\circ} \mathrm{C}$ & $750^{\circ} \mathrm{C}$ & $70-90^{\circ} \mathrm{C}$ \\
\hline Utility scale (>50 MW) & $\checkmark$ & $\checkmark$ & $\checkmark$ & $\checkmark$ & $\checkmark$ & \\
\hline Distributed (<10MW) & $\checkmark$ & & & & $\checkmark$ & $\checkmark$ \\
\hline Energy Storage & & $\checkmark$ & & $\checkmark$ & & $\checkmark$ \\
\hline $\begin{array}{l}\text { Hybrid with fossil } \\
\text { energy }\end{array}$ & & $\checkmark$ & $\checkmark$ & $\checkmark$ & & \\
\hline Water use (non-cooling) & to none & $\diamond \diamond$ & $\diamond \diamond$ & $\diamond \diamond$ & $\bullet$ & ** \\
\hline Water use for cooling & - & preferred & preferred & preferred & - & - \\
\hline Land Use (acre/MW)* & $5-9$ & $5-9$ & $3-6$ & $3-9$ & $8-9$ & $50-90$ \\
\hline Land Slope & $<5 \%$ & $<3 \%$ & $<3 \%$ & $<5 \%$ & $<5 \%$ & $<5 \%$ \\
\hline Commercial Maturity & $\begin{array}{l}\text { low to } \\
\text { high }\end{array}$ & high & low & medium & Low & low \\
\hline
\end{tabular}

* Values from utility-scale plants and proposed projects. Land use varies with resource quality, module or system efficiency, and inclusion of thermal energy storage. Plants with storage occupy more land per MW capacity, but less land per MWh generated.

** Evaporative losses occur from solar ponds, but water consumption data are not available.

All of the technologies listed in Table A3 have been technically demonstrated or are in commercial practice. As such, they are all at technology readiness levels of 8 or 9 . Their level of commercial maturity is indicated as low to high, depending on the number of plants in operation. For example, dozens of parabolic trough plants have been in operation for years to decades, while linear Fresnel systems are just entering commercial use. The commercial maturity of PV technologies ranges from low to high depending on the specific cell architecture, as well as use of solar concentration and tracking. Dish/engine and solar pond systems have been demonstrated, but have little commercial deployment and consequently few cost data.

Cost for solar power technologies has fallen dramatically in the past few years due to new technology development, lower cost manufacturing, and deployment volume. Figure A8 (Bolinger and Weaver 2013) shows PPA prices for utility-scale solar projects in the United States. PPA prices are market prices that include tax incentives and subsidies. The project list is dominated by solar PV systems, with solar PV prices falling from $\$ 150 / \mathrm{MWh}$ to $\$ 200 / \mathrm{MWh}$ to about $\$ 70 / \mathrm{MWh}$ over the last few years. The sunset of the $30 \%$ solar investment tax credit (ITC) back to $10 \%$ at the end of 2016 will raise PPA prices as developers can no longer realize the larger subsidy. That change can be expected to raise PPA prices to about $\$ 10 / \mathrm{MWh}$ to \$20/MWh. 


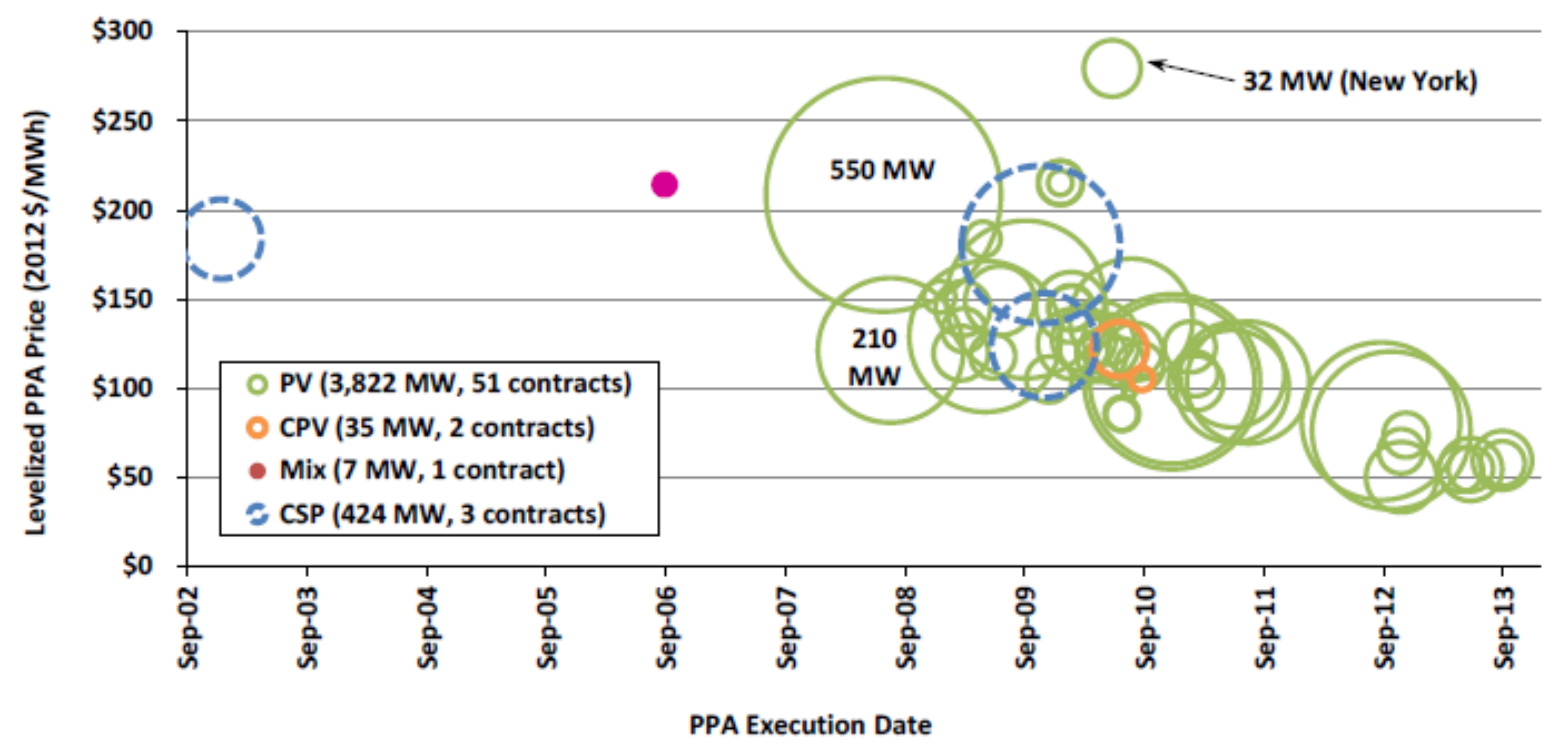

Source: Bolinger and Weaver 2013

Figure A8. Levelized power purchase agreement price for utility-scale U.S. solar projects.

As indicated by Figure A10, PV systems are the most common and lowest cost solar power technology. CSP systems with thermal energy storage provide more consistent and often more valuable power, with fewer issues related to power integration, but at a higher levelized cost per $\mathrm{kWh}$. Power generation with solar ponds is very low efficiency due to the low temperature of these systems; however, they can provide uninterrupted heat for industrial or commercial process.

Solar energy research at the federal level is driven by the objectives of the Department of Energy's SunShot Initiative. ${ }^{82}$ This program has set the goal of achieving market-competitive solar power, without subsidies like the ITC, by 2020. The accepted target cost for utility-scale solar power under the SunShot program is $\$ 60 / \mathrm{MWh}$, based on real 2010 dollars. The SunShot goals correspond to total capital required of about $\$ 1,000 / \mathrm{kW}$ for solar PV plants and $\$ 3,800 / \mathrm{kW}$ for CSP with enough thermal energy storage to provide a 66\% capacity factor (Sunshot 2012). Data from the NREL Annual Technology Baseline ${ }^{83}$ is summarized in Table A4.

Table A4. Representative Current and Future Utility-Scale Solar Costs

\begin{tabular}{|l|c|c|c|}
\hline Technology & Capacity Factor & $\begin{array}{c}\text { Overnight Capital Cost } \\
(\$ / \mathbf{k W})\end{array}$ & Fixed O\&M (\$/kW-yr) \\
\hline & & 2015 & 16 \\
\hline Utility-scale PV & $14 \%-26 \%$ & $2,986-3,670$ & 71 \\
\hline CSP & $25 \%-49 \%$ & $8,272-10,168$ & 8 \\
\hline & \multicolumn{3}{|c|}{2030} \\
\hline Utility-scale PV & $15 \%-27 \%$ & $\$ 1,094-\$ 2,189$ & 51 \\
\hline CSP & $25 \%-49 \%$ & $\$ 3,710-6,177$ & \\
\hline
\end{tabular}

Source: NREL ATB

${ }^{82}$ SunShot Initiative, accessed at http://energy.gov/eere/sunshot/about

${ }^{83}$ NREL, Annual Technology Baseline and Standard Scenarios (web page, http://www.nrel.gov/analysis/data_tech_baseline.html). 
Research under the SunShot program covers a wide range of topics that includes work to understand and develop basic components such as solar PV cells, heat transfer fluids, and optical materials and coatings; applied work on manufacturing processes and essential subsystems; modeling and analysis of the electric grid to understand and optimize integration of renewable power systems, exploring and attacking impediments to market penetration; and promoting workforce training and market transparency to help make solar deployment faster and more efficient. A summary of the entire program can be found in the SunShot Initiative Portfolio $2014 .^{84}$

\section{Impact of Airborne Dust on Solar Collectors}

Airborne dust can inherently disrupt the transfer of solar energy to reflectors and collectors. The impact to collection efficiency varies with numerous factors, including technology type, dust characteristics, and humidity-the latter factors being highly location specific. The following summary is taken from a recent review of the issues in a 2012 Science Undergraduate laboratory Internship report (Sarver et al. 2012):

- The impact of dust and soiling is highly dependent on local conditions. Natural cleaning by rain and other moisture in temperate, tropical, and wet climates can be beneficial; however in arid, desert climates, occasional rain and dew can lead to more severe soiling problems due to cementation of settled dust.

- Dust degrades the energy delivery of both solar PV and CSP systems. Reduction in solar intensity reaching the solar converter has been evaluated and documented for the past five decades, and this reduction for uncleaned systems can be in the range of $20 \%$ to $50 \%$, or more. For PV systems, the soiling derate assumption is site specific, but typically varies between 1.5 and $6 \%$ for the region in question depending primarily on rainfall, dust, and air pollution (Kimber et al. 2006). Soiling is a more critical issue for reflective, i.e., CSP-relevant, surfaces. Small losses in surface reflectivity of a mirror result in major losses in CSP performance. In general, concentrating systems are more sensitive to dust in the air and dust accumulation and require more maintenance from the perspective of dust mitigation.

- Much of the dust mitigation work has focused on the restorative approach, i.e., surface washing. The most common approach involves periodic cleaning with vehicle-mounted systems with forced water jets. Work has also looked at the effects of mechanical cleaning with air flows and air/water combinations from nozzles to reduce water consumption. The cleaning method of choice remains water washing with either demineralized water or dilute detergent solutions. These systems are very effective, typically maintaining surfaces within a few percentage points of their "clean" reflective or transmissive performance. The availability of high-purity water is critical and work has been devoted to minimizing water consumption during cleaning. Recommended cleaning intervals depend on the geographic location and climatic zone, and system performance should be estimated based on the average, soiled condition. Common cleaning intervals are every few days for CSP mirrors; solar PV systems are usually cleaned much less frequently. Water consumption with conventional truck-mounted

\footnotetext{
${ }^{84}$ SunShot Initiative, Tackling Challenges in Solar: 2014 Portfolio, U.S. Department of Energy, DOE/EE-1081, May 2014. Accessed at http://energy. gov/eere/sunshot/about.
} 
sprayers for parabolic trough cleaning has been reported as 0.6-0.8 liters per square meter of collector area per event (Turchi et al. 2010).

- Research in preventative approaches includes both passive methods (which use coatings that prevent the attachment of the dust) and active methods (which actually repel the charged dust particles). Investigation of these more sophisticated methods continues with substantial inputs from the materials science, chemistry, physics, and engineering research communities. In the coatings area, recent developments with (super-) hydrophilic (and superhydrophobic) materials have led to some promising results that are potentially effective for both dry and "wet" dust conditions. However, the lifetime of these coating still needs to be validated. The inclusion of active layers to repel dust has grown out of interest and developments within the space industry. Several approaches have shown effectiveness and continue to be tested, evaluated, and analyzed for both technical and economic readiness.

A brief description of each of the solar technologies is provided in the following sections.

\section{Solar Photovoltaic Technologies}

Solar PV, as the name implies, are devices that convert sunlight directly into electricity. Solar PV generates power without no appreciable noise, pollution, or fuel consumption. Solar PV systems involve few moving parts and require little routine maintenance, especially compared with other power generation technologies. One disadvantage of solar PV and solar power in general is that it requires a large surface area per $\mathrm{kW}$ of power because sunlight is a diffuse resource. Efforts to make systems more efficient and to utilize unused or previously disturbed space, such rooftops or former agricultural land, can mitigate this problem.

A solar PV system consists of three basic subsystems: solar PV modules, power electronics, and structural and wiring hardware, commonly referred to as balance of system. PV module technology falls into two major technology groups, crystalline silicon and thin film, and there are two basic types of crystalline silicon (c-Si) PV: monocrystalline and multicrystalline. Silicon PV cells come in wafer form. Monocrystalline PV wafers are cut from single-crystal silicon ingots, while multicrystalline wafers are either cut from directionally solidified blocks or grown in thin sheets. In each case, the silicon is produced in such a way that an internal electric field is created in the wafer, and positive and negative electrical connections are added to form a cell as shown in Figure A9. The circuit is completed for each cell and multiple cells are then linked and encapsulated to form modules.

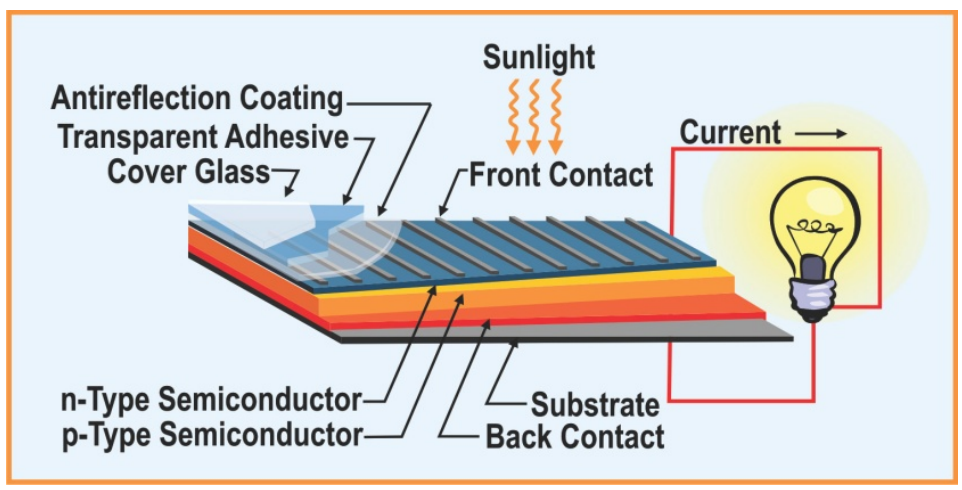

Figure A9. Typical PV cell construction. Illustration by NREL 
In contrast, thin film PV is deposited directly onto a rigid or flexible substrate. This substrate/ film structure is then integrated with electrical connections to form a circuit. Thin-film PV may use any of several different substances and various deposition methods can be used on a variety of substrates. Thin-film PV technology is categorized according to the photovoltaic material used. These include:

- Amorphous silicon (a-Si) and other thin-film silicon

- Cadmium Telluride (CdTe)

- Copper indium gallium selenide (CIGS)

- Dye-sensitized solar cell (DSC) and other organic solar cells.

Currently, CdTe is the most commonly used thin-film material. CdTe thin-film PV modules tend to be lower cost and lower efficiency versus silicon modules, and advances continue to be made in all the cell technologies (Figure A10).

The power electronics are an essential part of the PV system, in particular, an inverter converts direct current (DC) to alternating current (AC), and a transformer steps the electricity up to the appropriate voltage. Finally, the remaining components and procedures required to produce a complete PV system - mounting and wiring hardware, installation, etc. — constitute the balance of system.

Solar PV systems can be fixed in position, often tilted toward the south (in the northern hemisphere), or mounted on a tracker to better capture sunlight throughout the day (Figure A11). There are also concentrating PV (CPV) technologies that use trackers and lenses or mirrors to focus the sun's rays onto a high-efficiency PV cell. CPV systems use concentrating optics and more efficient (but more expensive PV cells). Concentrating optics allow the design to focus more sunlight on the high-efficiency cell. 


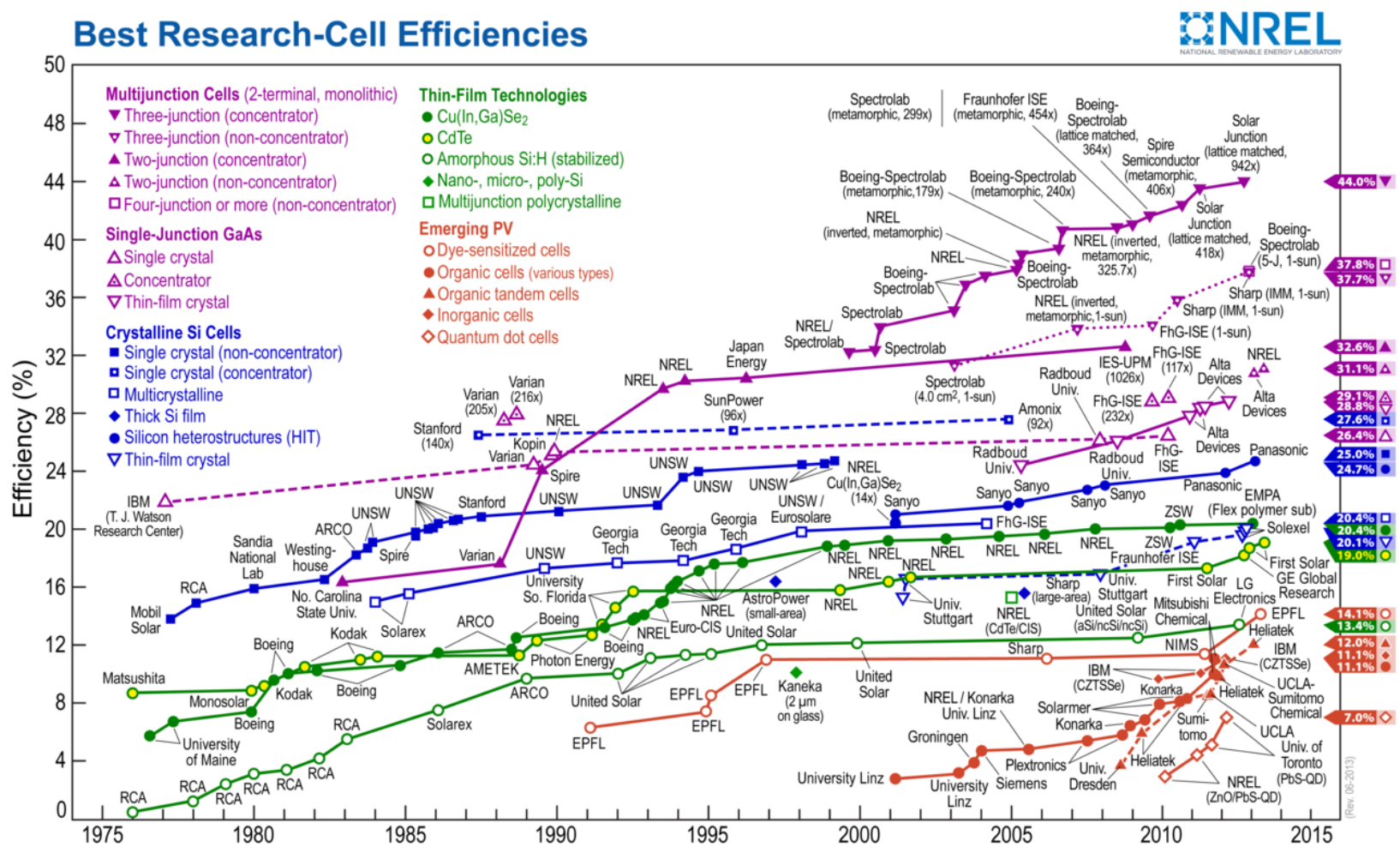

Figure A10. PV cell efficiencies for various technologies under standard laboratory conditions.

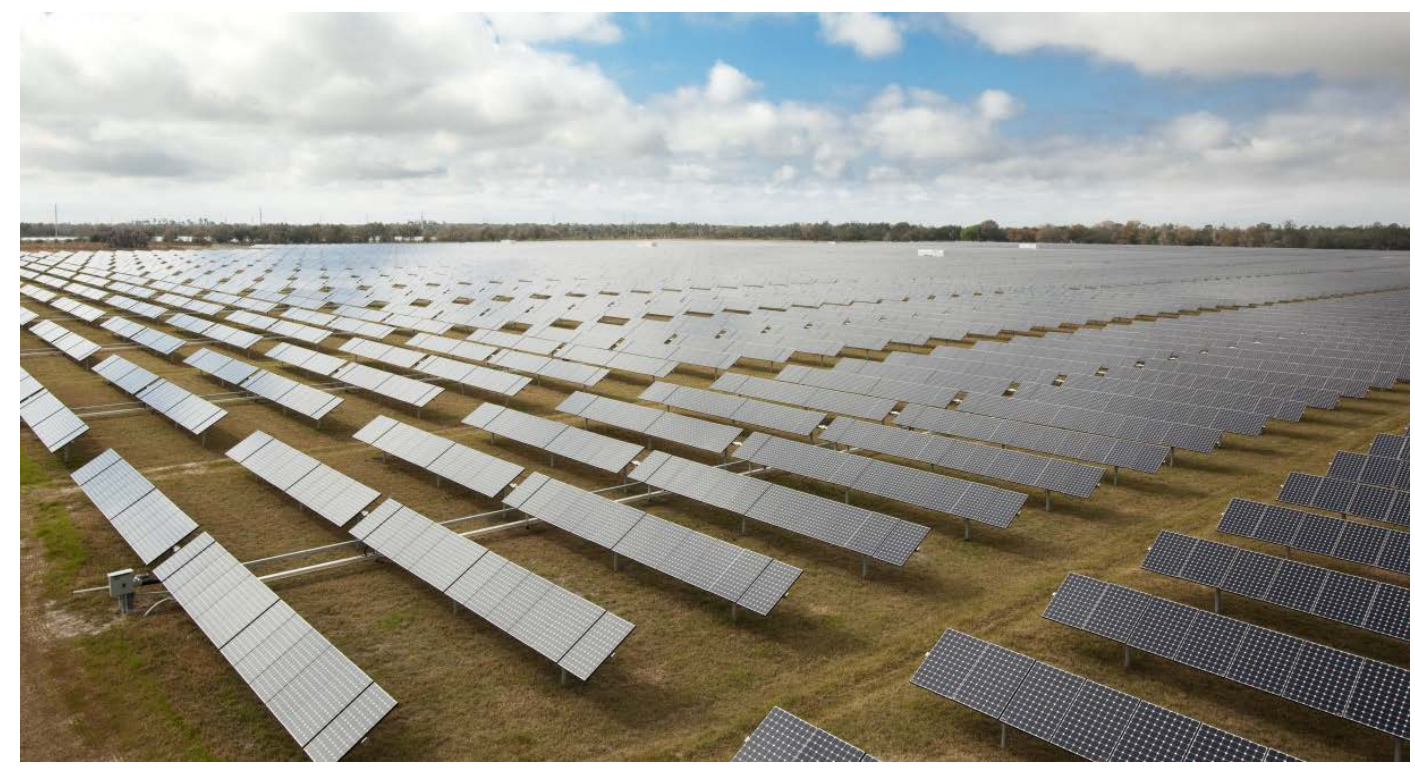

Figure A11. PV arrays placed in a fixed-tilt position or mounted on a tracker. Photo by NREL

As PV module and system costs have fallen in the last few years, PV installations have climbed across the United States (Figure A12). Utility-scale plants represent the lowest cost systems and have seen the greatest growth, with most deployment activity in California. 


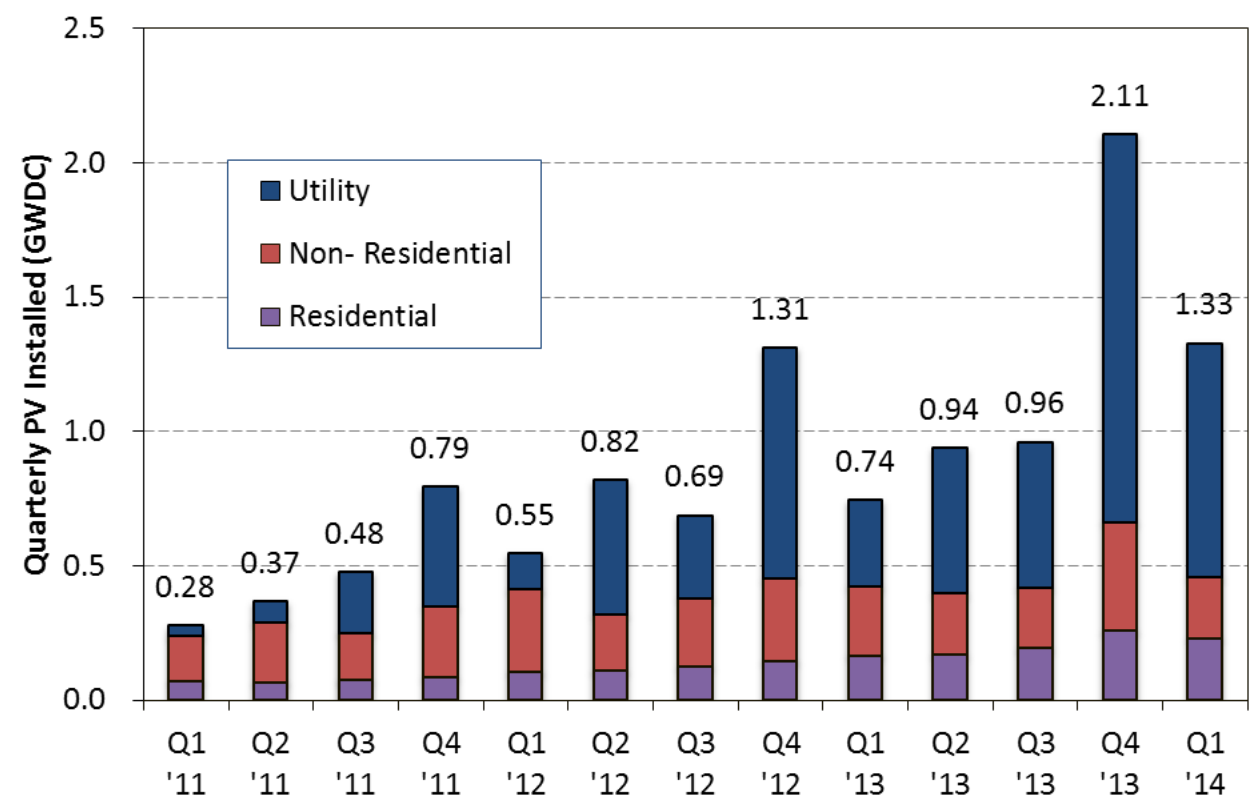

Source: GTM/SEIA U.S. Solar Market Insight Q1 2014

Figure A12. U.S. PV installations by market segment.

\section{Concentrating Solar Power Systems}

Concentration solar power systems differ from photovoltaic systems in that the solar energy is first captured as heat before being converting into electricity by a thermo-electric power cycle. CSP technologies include parabolic trough, linear Fresnel, power tower, and dish/engine systems. A major benefit of most CSP technologies is the ability to incorporate thermal energy storage to enhance reliability and dispatchability.

\section{Parabolic Trough Systems}

Parabolic trough power plants are the most mature of the CSP technologies, with over 3,500 MW in operation worldwide and some plants operating since the $1980 \mathrm{~s} .{ }^{85}$ Trough power plants have large arrays of solar collectors that feature mirrors curved in the shape of a parabola (or trough) to focus sunlight onto a pipe (Figure A13). A heat-transfer fluid (HTF), often synthetic oil, flows through the receiver pipe and is heated by the absorbed sunlight. This hot fluid is used to generate steam that turns a conventional steam turbine/generator to produce electricity. The spent steam from the turbine is condensed into water and recirculated by feedwater pumps to be transformed back into high-pressure steam. Wet, dry, or hybrid cooling can be used to cool and condense the spent steam; the selection will influence water consumption, cycle performance, and cost. A parabolic trough plant is composed of several subsystems: solar collector field, receiver and associated HTF system, power block, thermal storage (optional), fossil-fired backup (optional), and necessary ancillary facilities (Figure A14).

\footnotetext{
${ }^{85} \mathrm{http}: / /$ www.solarpaces.org/
} 


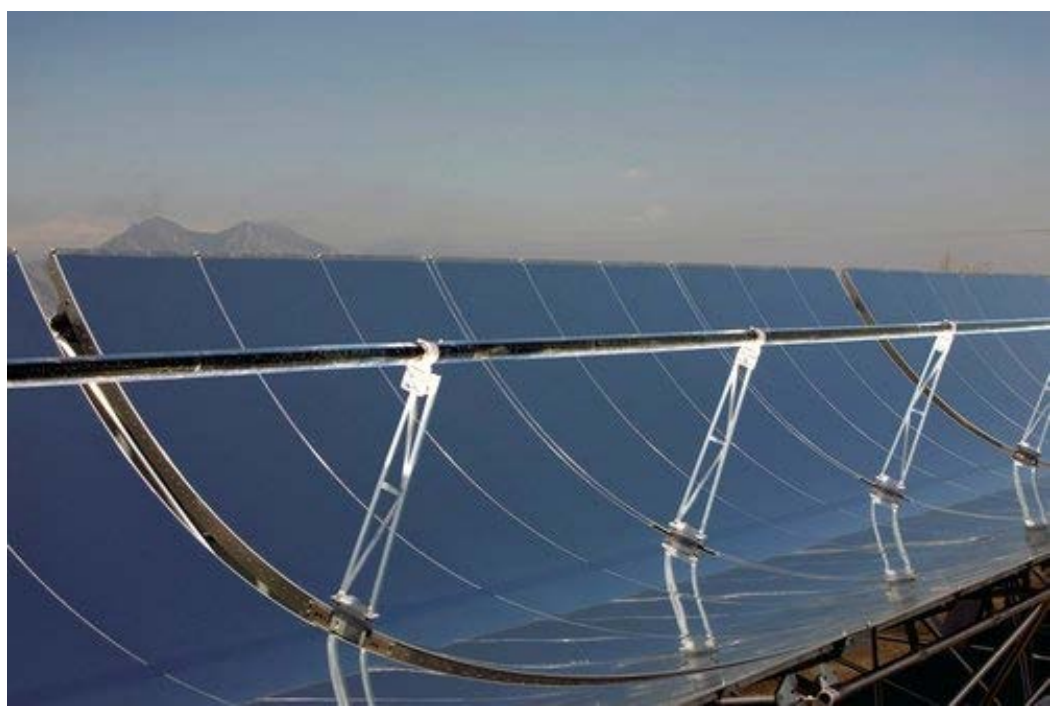

Figure A13. Parabolic trough collector and receiver tube. Photo from NREL 16604

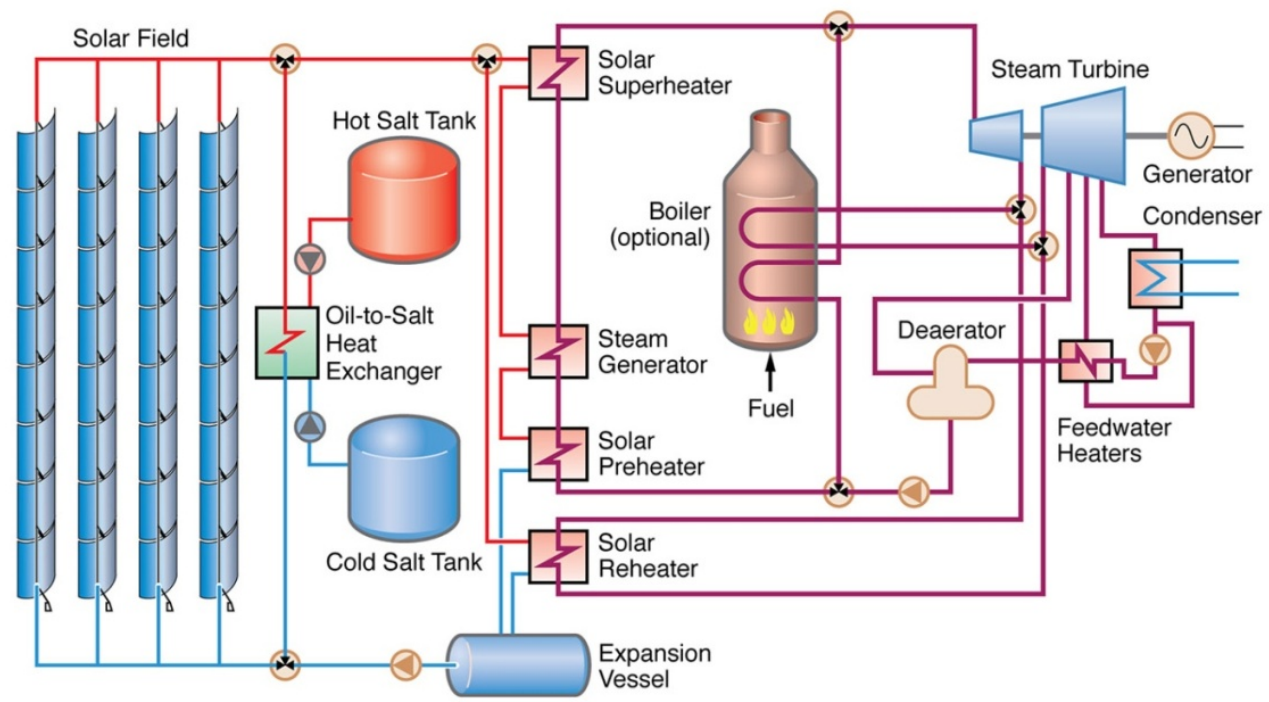

Figure A14. Simplified schematic of a parabolic trough power plant. Illustration from Electric Power Research Institute

\section{Linear Fresnel}

Linear Fresnel reflectors approximate the parabolic shape of a trough collector with long, ground-level rows of flat or slightly curved reflectors that reflect the solar rays onto an overhead linear receiver (Figure A15). A primary advantage of the linear Fresnel design versus the parabolic trough is the ability to keep the mirrors close to the ground and out of the wind. This feature, combined with flat reflectors and fixed receivers lead to lower capital costs relative to a parabolic trough plant. However, the collector simplicity advantages of the linear Fresnel system come with a cost; lower optical efficiency versus a parabolic trough. This lower optical efficiency is the main drawback of Fresnel systems with respect to troughs. On the positive side, the close-packing of linear Fresnel systems reduces the required land area compared to parabolic trough plants of equivalent capacity. 
Parabolic trough and linear Fresnel are both line-focus systems. In the case of the trough, the receiver pipe moves with the parabolic collector. In a Fresnel system the receiver is mounted high above the collector mirrors and does not move. This is a significant advantage for a Fresnel receiver because a fixed receiver is easier to build and maintain; a moving receiver requires flexible joints where the HTF enters and exits.

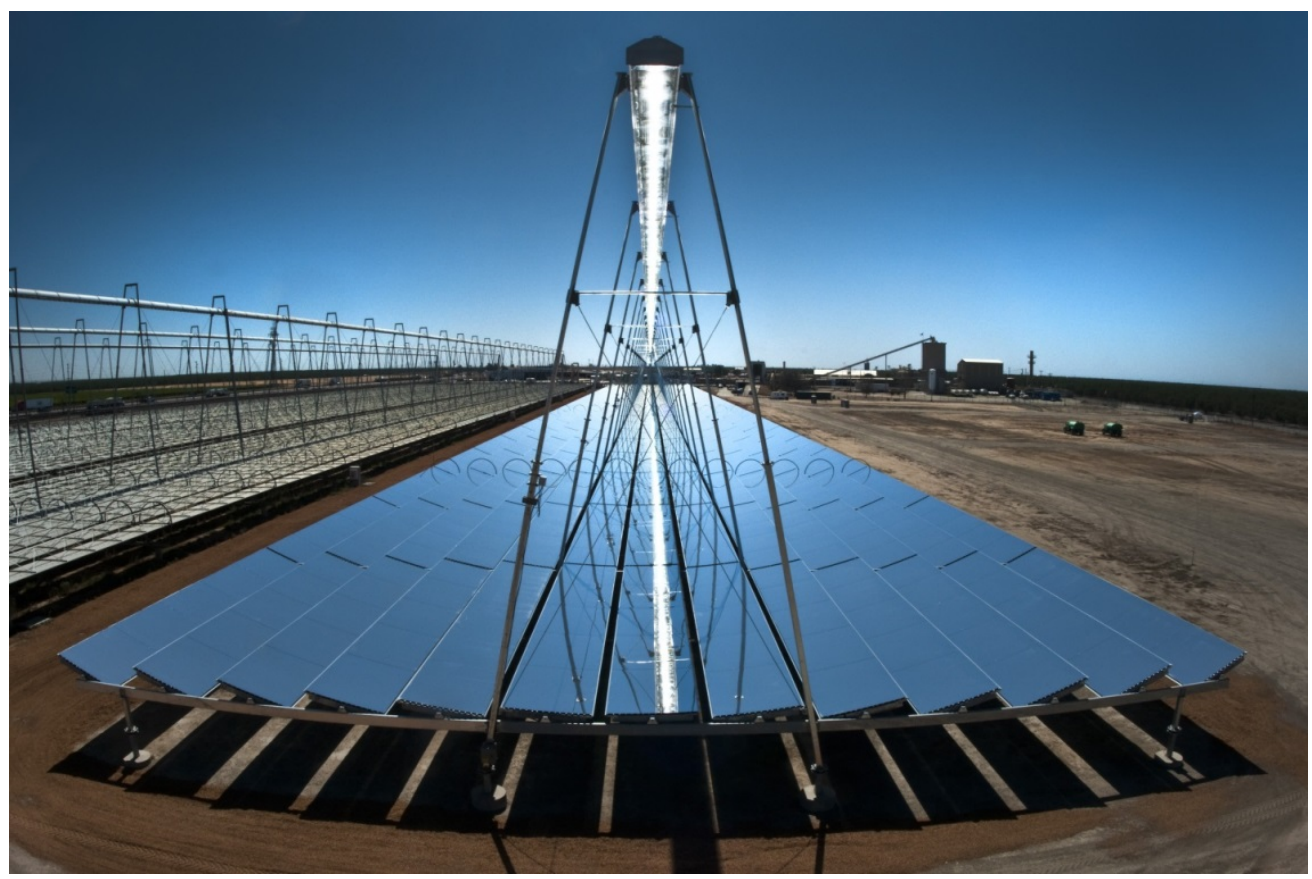

Figure A15. Linear Fresnel system made by Areva. Photo from NREL

Taking advantage of the benefits of a fixed receiver, most linear Fresnel systems use a water/steam HTF. That is, water flows though the receiver tube and is converted directly to steam. Direct steam Fresnel systems have achieved steam temperatures of greater than $400^{\circ} \mathrm{C}$ and some vendors hope to reach $500^{\circ} \mathrm{C}$ or above. Direct steam generation means there is no expensive oil HTF, nor need for a set of heat exchangers between the solar field and the steam turbine, further simplifying the plant design.

Some researchers have suggested that linear Fresnel systems could be deployed with a moltensalt HTF, such as done with power towers. Like a power tower, the linear Fresnel's non-moving receiver makes it easier to handle the molten salt. A molten salt HTF also makes it much easier to incorporate thermal energy storage by simply holding hot salt in an insulated tank. However, linear Fresnel plants still have substantial piping and protecting against salt freezing is not a trivial matter. Linear Fresnel systems are not as established as parabolic troughs and long term performance and cost data are lacking.

\section{Power Tower}

Whereas a parabolic trough or linear Fresnel plant moves fluid to solar collectors, a power tower system (Figure A16) moves the sunlight to a centrally located receiver. In essence, power towers spend most of their effort to move light rather than HTF. Power towers use heliostats (flat or nearly flat mirrors) that reflect sunlight onto a receiver. A large power-tower plant can utilize tens of thousands of heliostats, each under computer control. For this reason, power towers can 
be trickier to control than parabolic trough or linear Fresnel plants, but advances in software are overcoming these limitations.

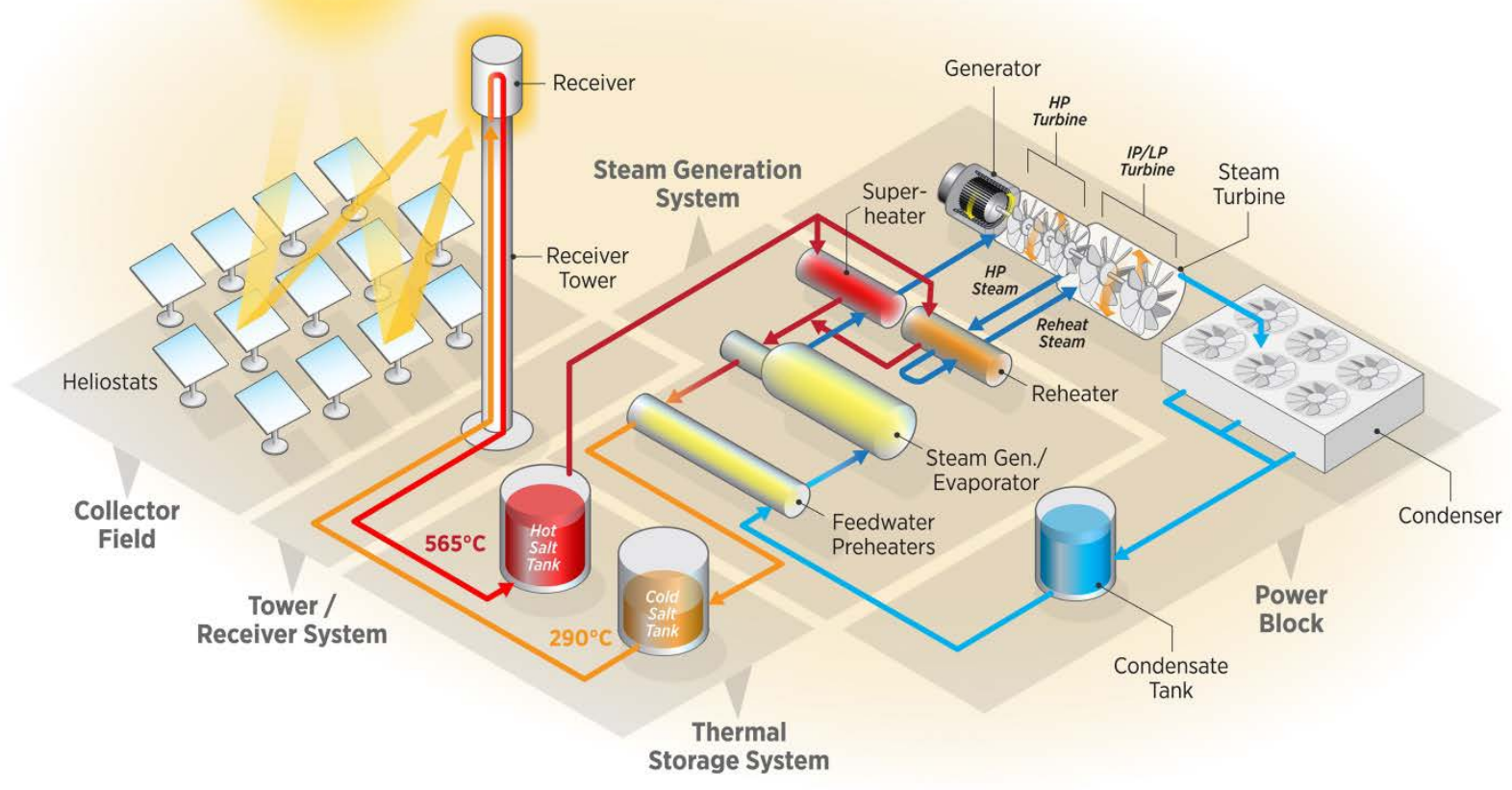

Figure A16. Schematic of a molten-salt power tower. Illustration by NREL

The two principal power tower designs are distinguished by the HTF in the receiver: steam or molten salt. In direct-steam power towers, heliostats reflect sunlight onto a receiver, which is basically a boiler mounted on top of a tower. Feedwater pumped from the power block is evaporated and superheated in the receiver to produce steam, which spins a turbine to generate electricity. Several characteristics of direct-steam power towers make them attractive: straightforward design; use of conventional boiler technology, materials, and manufacturing techniques; high thermodynamic efficiency; and low parasitic power consumption. Shortduration steam/water storage has been demonstrated at the 20 MW PS20 tower in Spain.

In a molten-salt power tower, "cold" salt at about $290^{\circ} \mathrm{C}$ is pumped from a storage tank to a receiver, where concentrated sunlight from the heliostat field heats the salt to about $565^{\circ} \mathrm{C}$. The salt is typically a mixture of sodium and potassium nitrate, which is a blend known as "solar salt". The hot salt is collected in a storage tank, and when power generation is required, hot salt is pumped to the steam generator, which produces high-pressure steam to spin a turbine/generator. The now-cooler salt from the steam generator is returned to the cold storage tank to complete the cycle. Owing to the negligible vapor pressure of the salt, both storage tanks are at atmospheric pressure. By placing the storage between the receiver and the steam generator, solar energy collection is de-coupled from electricity generation, and one can produce power and collect sunlight at completely different rates. Thus, passing clouds or sunsets do not affect turbine output. A strong advantage of molten salt power towers is the low cost and high efficiency of thermal energy storage (TES). In a molten salt tower, TES is less than half the cost 
of salt TES in trough plants because the larger temperature range across the storage system enables more energy to be stored per mass of salt.

The molten-salt power tower was first demonstrated at the $10 \mathrm{MW}$ Solar Two project in the 1990s and has since been commercialized with 20 MW Gemasolar in Spain and 110 MW Crescent Dunes in the United States.

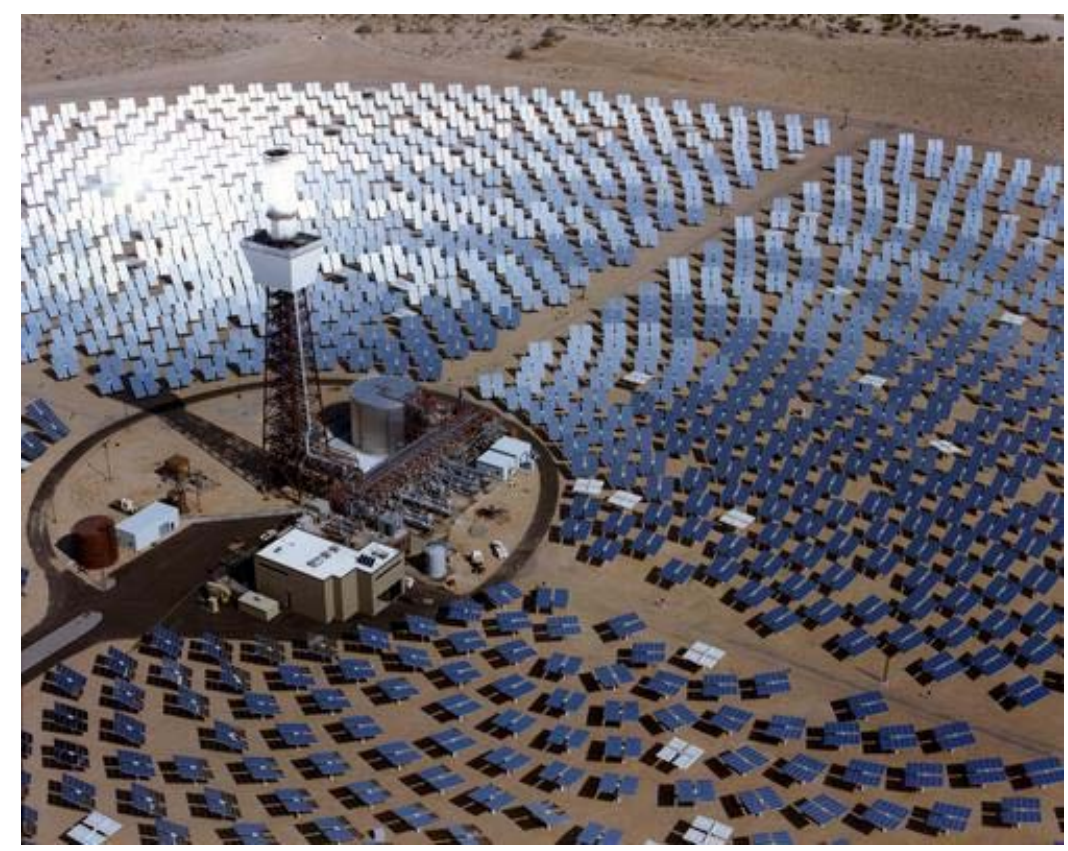

Figure A17. A molten-salt power tower. Photo from NREL

(Image credit NREL)

\section{Dish / Engine Systems}

Dish/engine CSP technology uses a reflector in the shape of a parabolic dish to concentrate sunlight. Parabolic dishes rotate about both the azimuth (compass direction) and elevation (height above ground) axes, constantly pointing at the sun as it crosses the sky. The reflected sunlight is directed at a receiver mounted on an arm extending out from the center of the dish (Figure A18). Within the receiver, a heater head collects this solar energy and uses the power to run an engine-driven generator to produce electricity. 


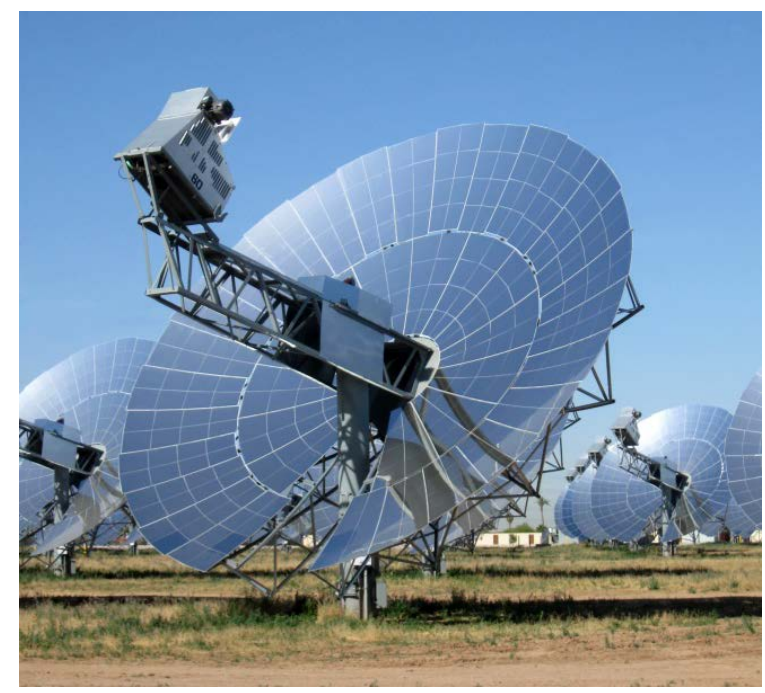

Figure A18. 25 kW dish/Stirling engine system made by Tessera Solar. Photo from NREL

As a modular technology, dish/engine systems are replicated to the scale required to meet the needs of each project site, potentially satisfying loads from $\mathrm{kW}$ to $\mathrm{GW}$. Dish systems can be installed on relatively uneven land, with $5 \%$ or more slope, thereby reducing the cost of site preparation for new projects.

Most dish systems use a form of the Stirling engine, although steam systems and air-Brayton turbines have been investigated. Dish/Stirling systems have demonstrated the highest in-thefield, solar-to-electric efficiency (31.4\%) of any solar technology. Dish/Stirling systems are aircooled by closed-loop systems (similar to an automobile engine), which, combined with the lack of a steam cycle, endow them with the lowest water use among all the CSP technologies.

Dish/engine systems do not have a central power block and circulating HTF, so integrating TES must be done at each engine. This modular design eliminates the economy of scale advantage enjoyed by centralized TES systems. Small TES designs using phase-change materials have been proposed for dish/engine systems, but none are in commercial use. Lack of TES means dish/engine systems compete directly with modular PV systems. As PV costs have fallen, dish/engine system have not obtained much commercial success and the two most prominent U.S. developers, Infinia and Tessera Solar, have gone out of business, although Infinia's technology has reemerged under Qnergy.

\section{CSP Power Block}

Parabolic trough, linear Fresnel, and power tower CSP technologies rely on steam Rankine power cycles that are essentially the same as those used in coal and nuclear power plants. These power cycles input high quality thermal energy, produce electric power, and discharge lowquality heat. All thermoelectric power systems require cooling. The cooling step in a Rankine power block condenses the low-pressure steam back into water for reuse. The water can then be efficiently pumped back to high pressure and returned to the boiler to produce high-pressure steam. The overall conversion efficiency of thermal energy into electricity directly depends on the temperatures of the heat source (hot) and the heat sink (cold). In modern CSP plants the gross thermal-to-electric efficiency is around $36 \%-42 \%$, and overall solar-to-electric efficiency is around $22 \%$ to $25 \%$. 
Cycle efficiency is maximized when the highest possible heat source temperature and the lowest possible heat sink temperature are obtained:

$$
\text { Power Cycle Efficiency } \propto 1-\frac{T_{\text {cold }}}{T_{\text {hot }}}
$$

Because of this relationship, power plant developers seek a cooling system that provides the lowest possible heat sink temperature. In general, the most convenient low-temperature heat sink is provided by water - either directly in the case of once-through cooling with a body of water or indirectly through evaporation. Where water is scarce or expensive, the water-cooled design may not be practical.

While water is the preferred medium for power-cycle cooling, its availability may be limited by policy or cost. Under these conditions, the CSP plant designer can opt for an air-cooled system or, if some water is available, a hybrid design that uses both air and water for cooling. An aircooled condenser condenses the steam by forcing ambient air over a bundle of finned tubes containing the low-pressure steam. A typical hybrid system includes both an air cooled condenser and a wet-cooled tower operating in parallel and the size of each can be adjusted depending on the design intent. The basic attributes of these designs are summarized in Table A5 (Turchi et al. 2010).

Table A5. Characteristics of Different Cooling Methods

\begin{tabular}{|c|c|c|}
\hline Cooling Type & Advantages & Disadvantages \\
\hline $\begin{array}{l}\text { Wet } \\
\text { (cooling } \\
\text { tower) }\end{array}$ & $\begin{array}{l}\text { Lowest installed cost } \\
\text { Low parasitic electricity consumption } \\
\text { Typically provides lowest cooling } \\
\text { temperature; gives highest power cycle } \\
\text { efficiency }\end{array}$ & $\begin{array}{l}\text { High water consumption } \\
\text { Water treatment and waste water } \\
\text { (blowdown) disposal required } \\
\text { Cooling tower plume in cold weather }\end{array}$ \\
\hline $\begin{array}{l}\text { Dry (Air } \\
\text { cooling) }\end{array}$ & $\begin{array}{l}\text { No water consumption } \\
\text { No water treatment required } \\
\text { No cooling-tower or blowdown pond } \\
\text { Lower O\&M costs (excluding fan power) }\end{array}$ & $\begin{array}{l}\text { More expensive equipment } \\
\text { Higher parasitic electricity } \\
\text { consumption } \\
\text { Poorer cooling at high dry-bulb temps } \\
\text { (cycle efficiency falls) }\end{array}$ \\
\hline Hybrid & $\begin{array}{l}\text { Reduced water consumption } \\
\text { Potential for lower levelized energy cost } \\
\text { compared to dry cooling } \\
\text { Maintains good performance during hot } \\
\text { weather }\end{array}$ & $\begin{array}{l}\text { Complicated system involving wet } \\
\text { and dry cooling; often highest capital } \\
\text { cost } \\
\text { Same disadvantages of wet system, } \\
\text { but to lesser degree }\end{array}$ \\
\hline
\end{tabular}

(Source: Turchi et al. 2010).

CSP Thermal Energy Storage

A very important characteristic of CSP technologies is the ability to provide power even when the sun is not shining. This is possible because most CSP systems can incorporate TES. In its simplest form, TES is achieved by storing a CSP plant's hot HTF in a large insulated tank. Such a system is simple and efficient, but overall cost depends on the cost of the HTF.

TES provides operating flexibility and enhanced dispatchability that can provide power when needed and makes life easier for electric grid operators. TES allows CSP plants to extend or shift 
energy generation to coincide with peak load demands. TES differs from electricity storage (e. $g$. , batteries) in several key ways. TES is more efficient and better suited to large-scale than batteries, and TES systems cost less and last longer than batteries. However, a TES system only works because a CSP plant produces heat first and then uses that heat to produce electricity. That is, TES only works in association with a CSP plant.

The current commercial TES option for parabolic trough systems uses molten nitrate salt as the storage medium in an indirect, two-tank system. Implementation of this TES system into parabolic trough power plants requires an indirect configuration-different HTF and storage fluids - because the oil HTF is too expensive to store directly and the storage salt has a high freezing point and could possibly freeze in the solar collectors if used as the HTF. Implementation of two-tank TES into molten-salt power towers is accomplished using direct storage of the molten salt HTF. The direct configuration eliminates the need for the heat exchanger required with indirect TES, thereby reducing cost and increasing the performance of the TES system. Roundtrip efficiency of TES in power towers has been estimated at $98 \%$ (Pacheco 2002). Direct TES is currently used in the Gemasolar power tower plant in Spain and the Crescent Dunes power tower in the United States.

\section{Solar Ponds}

Unlike the active solar collectors of the CSP technologies, a solar pond is a passive solar-thermal collection device that collects and stores thermal energy in a stratified shallow pond (Ranjan and Kaushik 2014). Solar ponds utilize a high-salinity mixture to maintain a density differential between the upper layer of the pond and the lower layer of the pond. In practice, a salt-gradient solar pond is stratified into three primary layers: an upper convective zone (UCZ) which sunlight passes through and may lose heat due to evaporation, a non-convective zone (NCZ) where there is a thermal gradient but ideally no mass transfer, and a hot, lower convective zone (LCZ) where sunlight is absorbed (Figure A19) (Ruskowitz et al. 2014).

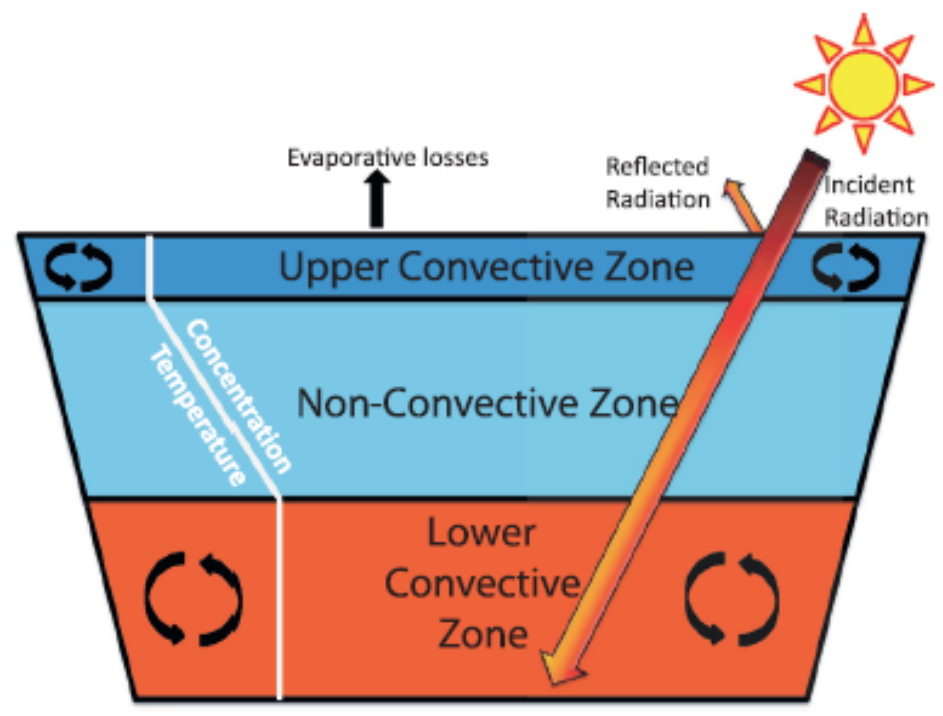

Source: Ruskowitz et al. 2014

Figure A19. Salt-gradient solar pond. 
Energy is extracted from the LCZ of the solar pond either by pumping the hot brine out to a heat exchanger or installing heat transfer piping in the pond itself. The former approach has been favored. Hot brine is extracted from one end of the pond via a distribution network and returned at the opposite end of the pond. Salt is a major cost in the creation of a salt-gradient solar pond, so regions that have high-salinity fluids available are preferred. The salt concentration ranges from 20-30 weight percent in the LCZ to near zero at the UCZ. Some make water is usually required to offset evaporative losses.

The solar gel pond (Figure A20) (El-Housayni and Wilkins 1987) is an alternative approach that uses a layer of polymer gel to separate the UCZ and LCZ. The gel layer density is designed to float on the LCZ and clear plastic sheeting can be used to encapsulate the polymer. The impermeable gel layer makes set up and control of the salt pond easier and pond depth can be shallower than in a salt-gradient solar pond. The salinity of the LCZ is about 2-7 weight percent. Advantages of the solar gel pond include: lesser salt requirement, lower evaporation rate, easier pond thermal management, and higher solar-to-thermal efficiency. The primary downside of this approach is a higher capital cost compared to the salt-gradient solar pond due to the cost of the polymer gel. However, reports indicate that the solar gel pond has a lower cost of delivered energy.

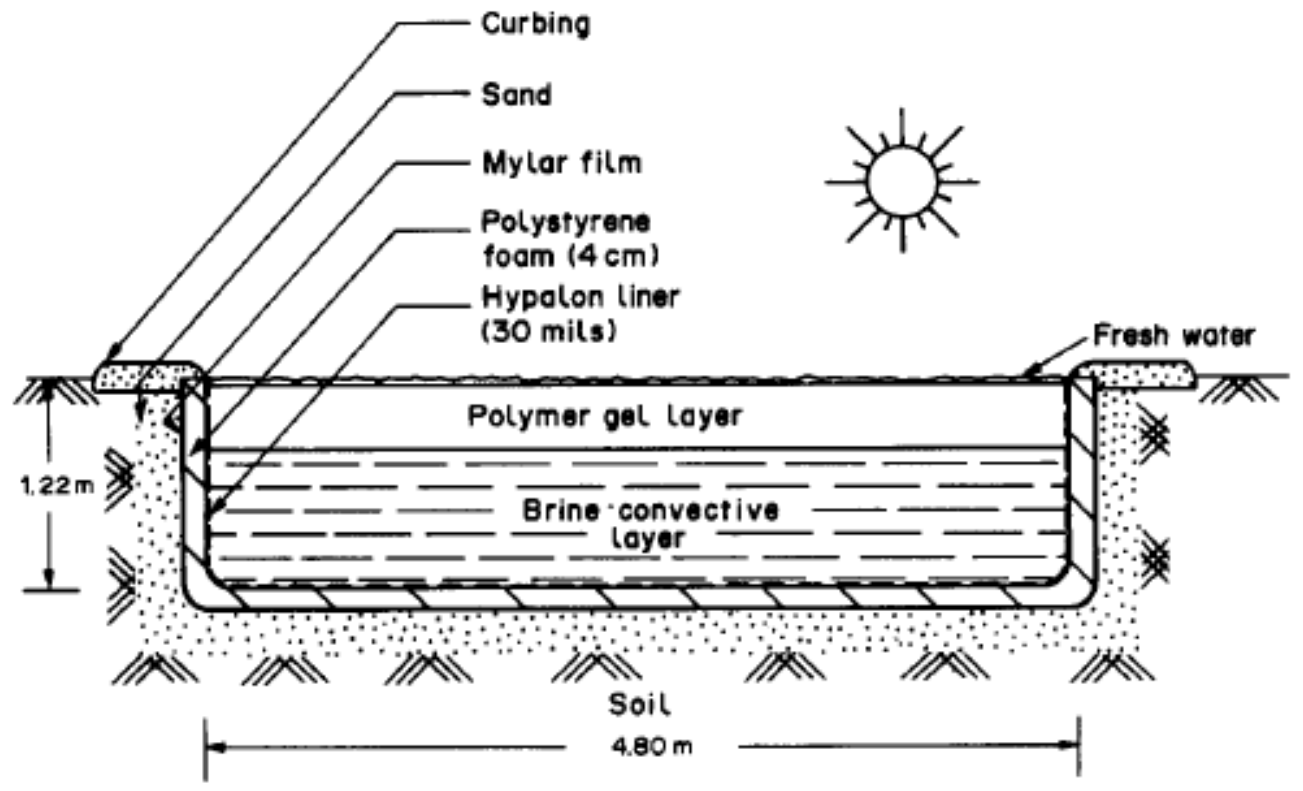

Source: El-Housayni and Wilkins 1987

Figure A20. A solar gel pond uses a polymer gel to separate the UCZ and LCZ layers.

The concept of the solar pond had been around for decades, but commercial development has been lacking. Test and prototype systems have been operated in several countries, including the United States (Figure A21). The annual solar-to-thermal efficiency of solar ponds has been reported as $15 \%$ to $25 \%$ (Ranjan and Kaushik 2014). Wang and co-workers report organic Rankine cycle (ORC) thermal-to-electric efficiencies on the order of $4 \%$ to $5.6 \%$ operating at conditions that would be compatible with a solar pond $\left(100^{\circ} \mathrm{C}\right.$ solar output to $25^{\circ} \mathrm{C}$ condenser $)$ (Wang et al. 2010). Assuming a 5\% thermal-to-electric cycle efficiency, a solar pond's annual solar-to-electric conversion efficiency would be on the order of $1 \%$, or $\sim 10-20$ times lower than a 
PV or CSP power system. To date, this low power conversion efficiency has prevented economic power generation from a solar pond.

Solar ponds are best suited for supplying low-grade thermal energy in moderate latitude regions $\left( \pm 40^{\circ}\right)$ with good sunlight. Temperatures reaching $100^{\circ} \mathrm{C}$ are possible, but $\approx 70^{\circ} \mathrm{C}$ is more typical. Their large thermal capacity offers $24 / 7$ energy delivery. The ponds require large, relatively flat land areas, with a manageable individual pond area of several hectares ( $\sim 10$ acres). Agha estimated the cost of $70^{\circ} \mathrm{C}$ thermal energy from a solar pond at 1.4 to $2.3 \notin / \mathrm{kWh}(\$ 4-\$ 6.7$ per one million British Thermal Units (MMBTU)) depending on salt cost (Agha 2009). For comparison, natural gas costs in the United States are currently about at \$2.85/MMBTU, but several times higher in much of the rest of the world. ${ }^{86}$

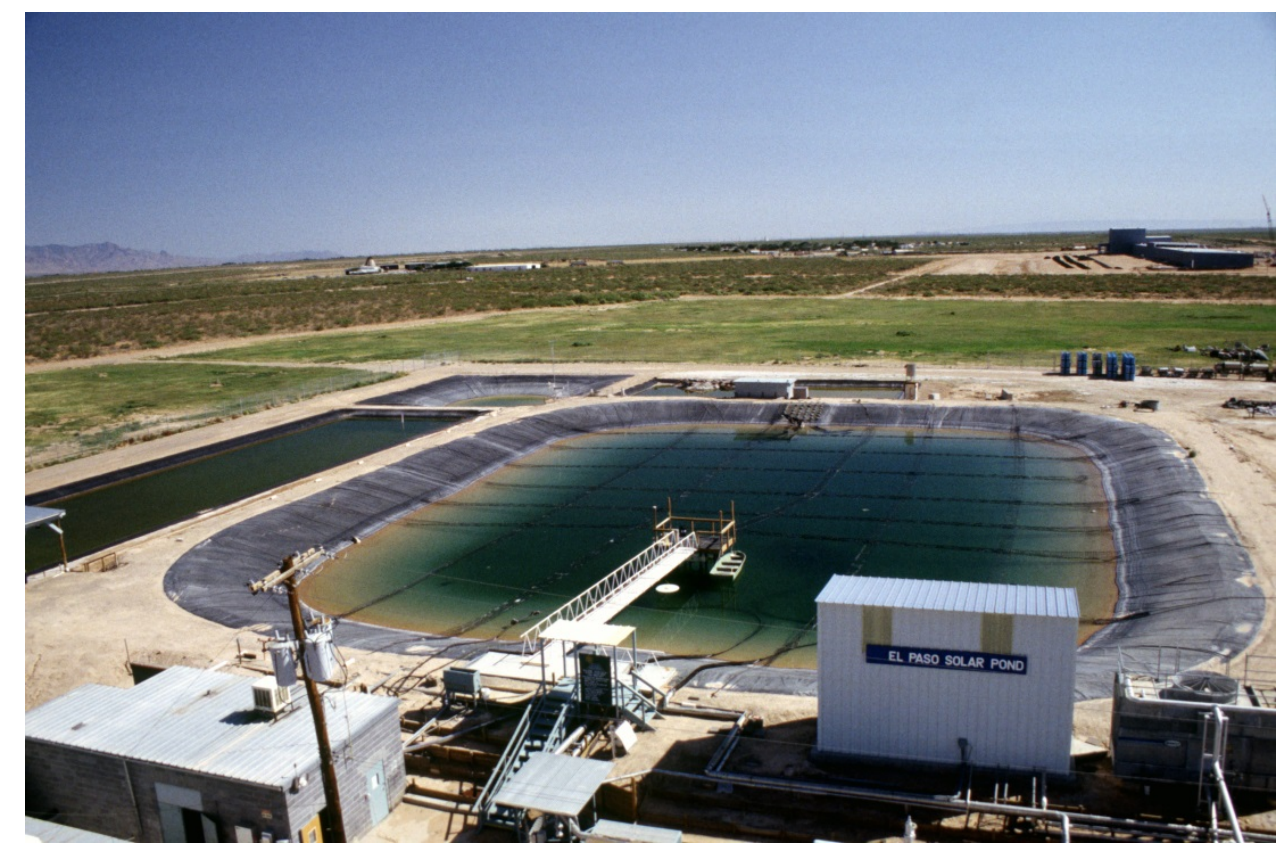

Figure A21. Solar pond test facility at the University of Texas EI Paso. Photo by NREL 08841

\section{Algal Biofuel Production}

The opportunities and challenges of algae are plentiful. This section will describe the basic processes of algal biofuel production while addressing prominent opportunities and challenges which affect the IID.

\section{The Role of Algae and Biofuels}

While the most common biomass feedstocks utilized today are terrestrial plants, oil-rich, carbon dioxide (CO2)-utilizing photosynthetic microalgae are technically viable alternatives. Using algal feedstocks to produce fuel, however, will require critical innovation to make it an economically viable option. Estimates for the current commercial production costs of algal biomass are approximately $\$ 1,500$ per ton. The two primary processes for conversion of algal

\footnotetext{
${ }^{86}$ US. Energy Information Administration. "Henry Hub Natural Gas Spot Price". 2015. http://www. eia. gov/dnav/ng/hist/rngwhhdM.htm, accessed April 27, 2015.
} 
biomass to liquid transportation fuels will require technological advances in algal cultivation, harvesting and dewatering to reduce the cost to approximately $\$ 300$ per ton (Davis et al. 2012).

\section{Past Algal Biofuels Research Efforts}

The Aquatic Species Program funded by DOE from 1978 to 1996 represents the most comprehensive research effort to date on fuels from algae. DOE invested \$22.1 million (nominal dollars) cumulatively over this time frame (Sheehan et al. 1998) to study a variety of aquatic species for use in renewable energy production, including microalgae, macroalgae, and cattails. The Aquatic Species Program demonstrated the feasibility of algal culture as a source of oil through algal strain isolation and characterization, studies of algal physiology and biochemistry, genetic engineering, engineering and process development, coupled with outdoor demonstration scale-up of algal mass culture. Techno-economic analyses and resource assessments were important aspects of the program, and helped prioritize resources toward the most important scientific and technical barriers. The program was discontinued when the optimistic estimates for the cost of algal biofuel production were in the $\$ 40$ to $\$ 60 /$ barrel range, a factor of two or three times higher than the cost of petroleum at that time (less than $\$ 20 /$ barrel in 1995). The program highlighted the need to understand and optimize the biological mechanisms of algal lipid accumulation and to find creative, cost-effective solutions for culture and process engineering development to isolate lipids from very dilute biomass suspensions.

DOE returned to the algal biofuels to overcome the limitations on production of biofuels from terrestrial biomass. The Billion Ton Study ${ }^{87}$ coauthored by DOE and U.S. Department of Agriculture (USDA) determined that it was feasible to produce approximately 1 billion tons of terrestrial biomass in the United States in a sustainable fashion. Given the theoretical yields for conversion of cellulosic sugars to biofuel of approximately 70 gge per ton of biomass, it was clear that terrestrial biomass could only support the production of 70 billion gge per year, a significant amount, but small in comparison with the 240 billion gallons of petroleum which we consume each year. ${ }^{88}$ An analysis of the resources available for cultivation of algae in the United States suggests that an equal amount of fuel could be produced each year from algal biomass (Wigmosta et al. 20011).

In 2008, DOE sponsored an Algal Biofuels Roadmapping workshop that identified the technology hurdles that needed to be overcome for commercial production of algal biofuels. The workshop and report, issued in 2010 set the stage for subsequent funding for R\&D by DOE which includes funding for four multi-institutional algae consortia: ${ }^{89}$

- National Alliance for Advanced Biofuels and Bioproducts

- Sustainable Algal Biofuels Consortium

- Consortium for Algal Biofuels Commercialization

- Cornell Consortium.

DOE has also provided support for build out and operation of pilot and demonstration scale production facilities for the algal biofuel companies, Sapphire, Solazyme, and Algenol. In

\footnotetext{
${ }^{87}$ U.S. DOE 2011- http://www1.eere.energy.gov/bioenergy/pdfs/billion ton update. pdf

${ }^{88} \mathrm{http}: / /$ www.eia.gov/tools/faqs/faq. $\mathrm{cfm} ? \mathrm{id}=23 \& \mathrm{t}=10$

${ }^{89}$ Information on all four consortia can be found here: http://energy.gov/sites/prod/files/2014/03/f14/algae_webinar.pdf.
} 
addition, USDA provided a $\$ 50$ million loan guarantee for the Sapphire demo facility. Since that time, DOE has issued a number of Funding Opportunity Announcements and has also provided non-competed funding for algal biofuel $R \& D$ at national labs and academic institutions.

NREL's current estimate for algal biofuel production is approximately \$17/gal, based on ALU (algal lipid extraction and upgrading) with ethanol as a co-product based on fermentation of the algal sugars released in the extraction process (Davis et al. 2012).

\section{Incentives for Biofuel}

In recognition of the energy security and environmental benefits of renewable liquid fuel production, legislation in the United States has been passed to support implementation.

\section{Renewable Fuels Standard (RFS)}

The Energy Independence and Security Act of 2007 (EISA) established the annual renewable fuel volume targets, mandating an overall level of 36 billion gallons of renewable fuel be blended into transportation fuel annually by 2022. To achieve these volumes, the Environmental Protection Agency (EPA) calculates a percentage-based standard for the following year. Based on the standard, each refiner, importer and non-oxygenate blender of gasoline determines the minimum volume of renewable fuel that it must ensure is used in its transportation fuel.

Table A6. EISA 2022 Overall Volumes and Standards

\begin{tabular}{|l|c|}
\hline Fuel Type & Volume (Billion Gal. ) \\
\hline Conventional biofuel or starch ethanol & 15 \\
\hline Advanced biofuels & 21 \\
\hline Cellulosic biofuels & 16 \\
\hline Biomass-based diesel & 1 \\
\hline Other advanced biofuels & 4 \\
\hline
\end{tabular}

Algal biomass can be used as a feedstock for the production of many different biofuels, depending on the conversion process. Algal lipids can be used to produce biodiesel or renewable diesel (diesel alternatives differentiated by their production methods), jet fuel and gasoline. Following lipid extraction, the remaining algal biomass can be converted to sugars and other simple molecules which can be used to produce ethanol and other advanced biofuels. It is generally understood that algal biofuels would fall under the heading of other advanced biofuels.

\section{Carbon Pollution Emission Guidelines for Existing Stationary Sources}

In June 2014, the EPA proposed rules for mitigation of CO2 emissions from power plants. ${ }^{90}$ The proposed rules generally favored carbon capture and storage technologies such as underground sequestration over carbon capture and use technologies of the sort being developed for algal biofuels. The algal biofuels community has made its voice heard regarding these rules to gain more support for their commercialization plans, but the EPA has not yet indicated that it would change its position.

\footnotetext{
${ }^{90}$ Federal Register 2014, https://www.federalregister.gov/articles/2014/06/18/2014-13726/carbon-pollution-emission-guidelines-for-existingstationary-sources-electric-utility-generating.
} 


\section{Production Stages}

The four main stages of algae-to-biofuel conversion are cultivation of the algae, harvesting of the algae, extracting the lipids and oils from the biomass, and conversion of the lipids or oils into a biofuel. Each of these stages offers a different set of challenges, some of which are mitigated by the resources available at the Salton Sea. A simplified version of an algal biofuels production process is shown in Figure A22.

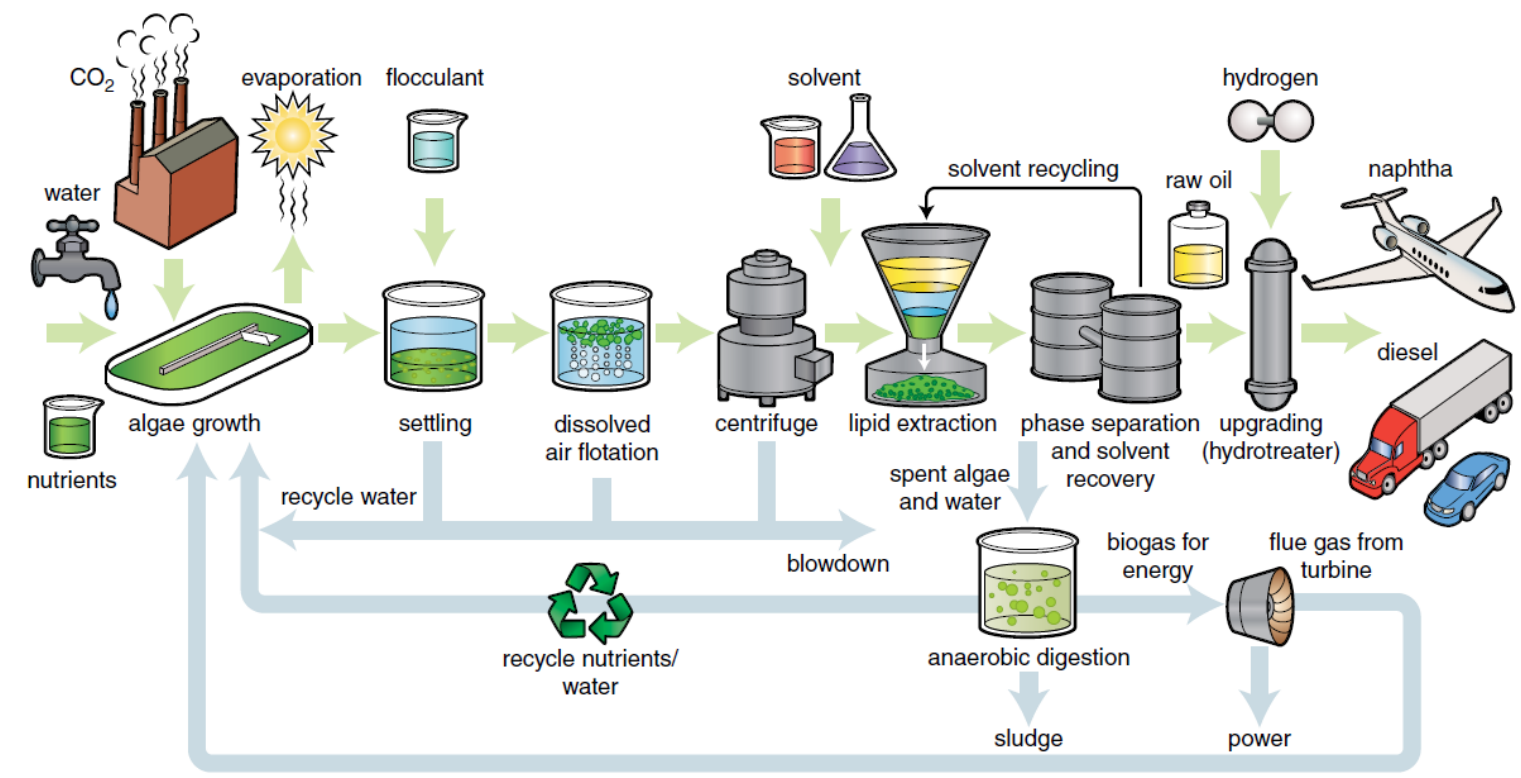

Source: Pienkos et al. 2011

Figure A22. Algal biofuels production process.

\section{Cultivation Technologies}

The production of microalgae for nutritional supplements is presently a small industry worldwide, with approximately 6,000 tons (dry weight organic material) being produced autotrophically (with sunlight and $\mathrm{CO} 2$ ) ${ }^{91}$ For comparison, a typical corn farmer produces about 10,000 tons of corn on 2,000 acres of crop land. However, the value of the microalgae crop to a food processer is about $\$ 10,000 /$ ton (for specialty human food supplement markets) compared with $\$ 100 /$ ton for the equivalent corn crop. The quality standards for algal cultivation for biofuel production are much lower than for food supplement production and thus the estimated cost for production is much lower as well (approximately $\$ 1000 /$ ton). It has been calculated that algal biofuel production could be economically viable if the cost of biomass production could be lowered to approximately $\$ 300 /$ ton. This will require improvements in the algal biology itself to achieve higher growth rates as well as reductions in the capital costs for the production system and operating costs for the harvest system.

A summary of the characteristics of the main cultivation systems is outlined in Table A7.

${ }^{91} \mathrm{http} / / /$ www1.eere.energy.gov/bioenergy/pdfs/algal_biofuels_roadmap.pdf 
Table A7. Summary of Algae Cultivation Characteristics (NREL)

\begin{tabular}{|c|c|c|c|c|}
\hline & $\begin{array}{l}\text { Large open, } \\
\text { unmixed } \\
\text { ponds }\end{array}$ & $\begin{array}{l}\text { Open raceway, } \\
\text { shallow mixed } \\
\text { ponds }\end{array}$ & $\begin{array}{c}\text { Closed } \\
\text { Photobioreactors }\end{array}$ & $\begin{array}{l}\text { Benthic Growth } \\
\text { Production Systems }\end{array}$ \\
\hline $\begin{array}{l}\text { Operating } \\
\text { Temperature }\end{array}$ & ambient & $5-30^{\circ} \mathrm{C}$ & $5-40^{\circ} \mathrm{C}$ & ambient \\
\hline Animal feed & & $\checkmark$ & $\checkmark$ & depends on water source \\
\hline $\begin{array}{l}\text { Wastewater } \\
\text { treatment }\end{array}$ & $\checkmark$ & $\checkmark$ & & $\checkmark$ \\
\hline $\begin{array}{l}\text { Biofuel } \\
\text { production }\end{array}$ & & $\checkmark$ & $\checkmark$ & $\checkmark$ \\
\hline Fertilizer & & $\checkmark$ & $\checkmark$ & $\checkmark$ \\
\hline Cost/Ton & $\begin{array}{c}\text { not } \\
\text { applicable }\end{array}$ & moderate & high & low \\
\hline Water use & $\checkmark$ to none & 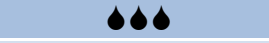 & $\diamond$ & $\checkmark$ to none \\
\hline $\begin{array}{l}\text { Land Use (ton } \\
\text { biomass/acre) }\end{array}$ & $\begin{array}{c}\text { not } \\
\text { applicable }\end{array}$ & $10-100$ & $10-100$ & $10-100$ \\
\hline $\begin{array}{l}\text { Maximum Land } \\
\text { Slope }\end{array}$ & $<5 \%$ & $<3 \%$ & $<3 \%$ & not applicable \\
\hline $\begin{array}{l}\text { Commercial } \\
\text { maturity* }\end{array}$ & Commercial & TRL 7 & TRL 5-6 & TRL 5-6 \\
\hline
\end{tabular}

*It must be noted that the TRL of the systems designed to produce biomass is low, and therefore the information in the table is a rough approximation.

There are five basic technologies currently used for microalgae production. The first four systems utilize sunlight, water, $\mathrm{CO} 2$, nitrogen and phosphorous to establish favorable environments for algae to grow. The rate of photosynthesis and growth of the algae depends in part on the balance of nutrients. The fifth technology utilizes growth on sugars or other organic compounds in the dark (heterotrophic growth), and appears to have limited benefits for fuel applications. Each technology has a different approach for establishing and maintaining this optimum growth environment.

Four basic algae harvesting technologies:

- Large open, unmixed ponds, for wastewater treatment and desalinized production. Wastewater treatment ponds, "oxidation ponds," are not true algae production ponds, as no algal biomass is harvested (Figure A23). A few wastewater treatment ponds are of a "high rate ponds" design, discussed below. Dunaliella salina production in Australia uses very large saline evaporation ponds ( $>100$ acres each). The algae dominate naturally in $>100 \mathrm{~g} / \mathrm{L}$ of salt and are produced at very low productivities (perhaps not much more than 1 ton/acre/yr). The algae are harvested by adsorption of polymers and their oil, which is very high in beta carotene, is extracted and sold commercially. The algal biomass has a value of $>\$ 50 / \mathrm{kg}$, based on the beta carotene content. ${ }^{92}$

${ }^{92} \mathrm{http}: / /$ www1.eere.energy.gov/bioenergy/pdfs/algal_biofuels_roadmap.pdf 


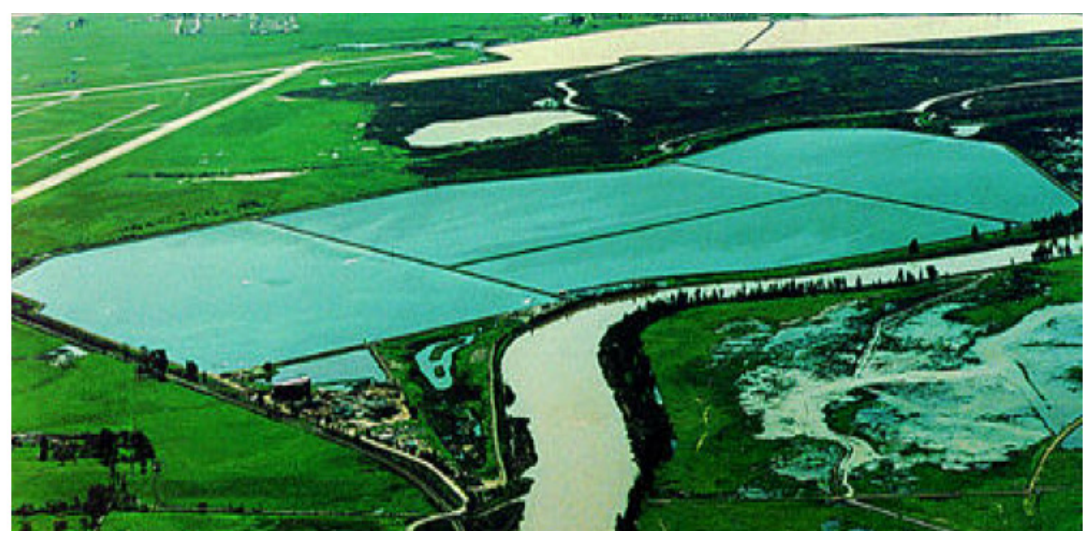

Figure A23. Typical oxidation pond. ${ }^{93}$

- Open, raceway, shallow, mixed ponds, 15 to $35 \mathrm{~cm}$ deep are typically mixed with paddlewheels, lined with plastic or cement (if necessary), and between 1/2 and 3/4 acres in total area. These are called high-rate ponds because their productivity is much higher (by approximately a factor of ten) than the unmixed ponds. The high-rate ponds are the main system currently used for the production of Spirulina (Arthrospira platensis) production world-wide, and also for commercial D. salina, Chlorella vulgaris, and Haematococcus pluvialis (for astaxanthin) production (Figure A24). Circular mixed ponds are still used in Chlorella production systems in the Far East, but are slowly being displaced by raceway-type designs. Estimated averages for the bulk selling prices are about $\$ 10 / \mathrm{kg}$ for Spirulina, $\$ 20 / \mathrm{kg}$ for Chlorella and $\$ 100 / \mathrm{kg}$ for Haematococcus (with Chinese production costs lower than other countries). ${ }^{94}$ Open ponds are the cultivation method of choice for four leading algae companies, Earthrise, Heliae, Sapphire, and Cellana. Until recently, only Sapphire was absolutely focused on biofuels, but changes within that organization indicate that it, too, has begun to focus on nearer term revenue generation with higher value products.

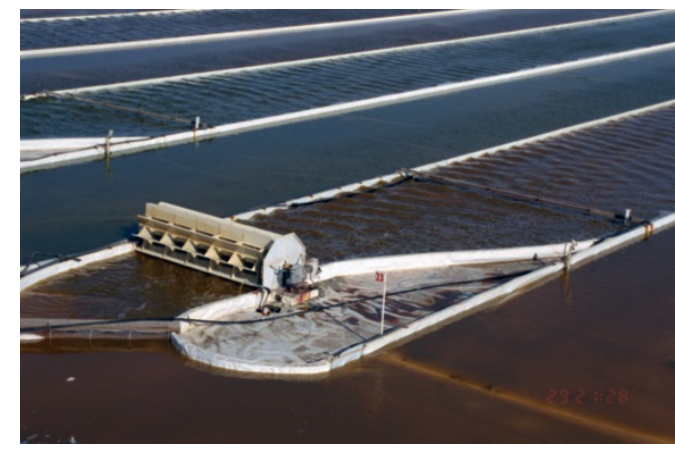

Figure A24. Spirulina production in open raceway ponds. Photo from NREL

- Closed photobioreactors, used in commercial operations have tubular reactors - either small diameter (approximately $5 \mathrm{~cm}$ ) or larger diameter $(>10 \mathrm{~cm}$ ), the latter generally being of a thin, non-rigid plastic bag type. Many other designs have been used, including

\footnotetext{
${ }^{93}$ Figure 2.5: Oxidation pond for wastewater treatment ( 100 ha, Napa, California). http://decarboni. se/publications/realistic-technology-andengineering-assessment-algae-biofuel-production/21-current-and-potential-uses-microalgae-biomass

${ }^{94}$ http://www.biofuelsdigest. com/bdigest/2015/02/11/sapphire-energy-biofuels-digests-2015-5-minute-guide/).
} 
flat plate reactors, hanging bag reactors, hemispherical dome reactors, etc. These closed photobioreactors are used to cultivate H. pluvialis commercially in Israel and in Hawaii and C. vulgaris in Germany, with typical prices well above $\$ 100 / \mathrm{kg}$, but hanging bag photobioreactors are now being deployed by Algenol for conversion of $\mathrm{CO} 2$ to ethanol along with fuel coproducts generated through processing of the biomass.

Photobioreactors with radically different configurations are being developed by Solix and BioProcess Algae.

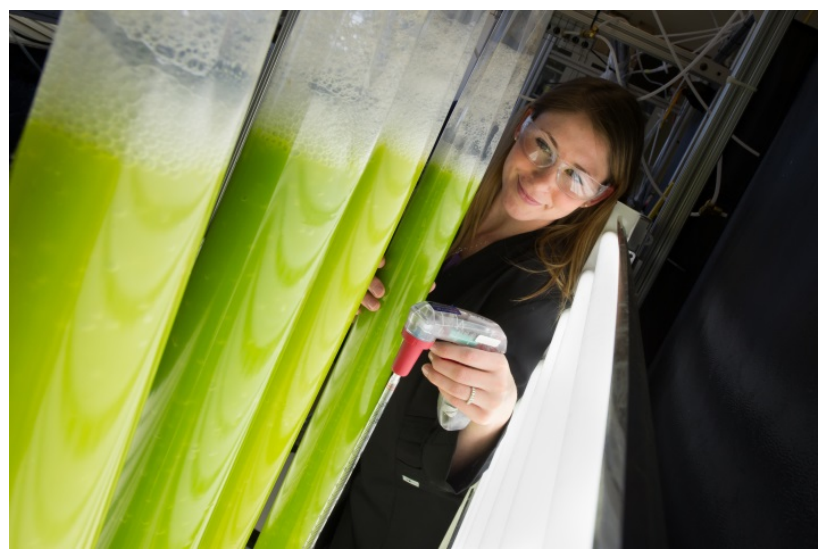

Figure A25. Samples being drawn from a tubular bag photobioreactor. Photo from NREL

- Benthic growth production systems are being developed often to cultivate and harvest algae grown in polyculture mode rather than in uniculture mode with specific production strains. These processes make use of a solid support that provides a substrate for algal cell attachment. These supports may be placed in bodies of water or waste water ponds to take advantage of natural mixing and nutrient supply. They are designed to provide a growth support for the indigenous algal population which could include several different species as well as bacteria and other microorganisms. With a mixed population of natural organisms, it is thought that robust growth could be obtained, at a price of control over biomass quality. The solid support can be removed from the water and the algal biomass removed by scraping, resulting in biomass that has been dewatered without the expensive harvest/dewatering processes needed for growth of free-floating (planktonic) algae. The most well known system for benthic growth is known as the TurfScrubber, though the BioProcess Algae photobioreactor involves benthic growth under a plastic tent to provide an atmosphere enriched in $\mathrm{CO} 2$. Proterro is commercializing a novel benthic growth mode photobioreactor to produce sucrose with minimal water usage. 


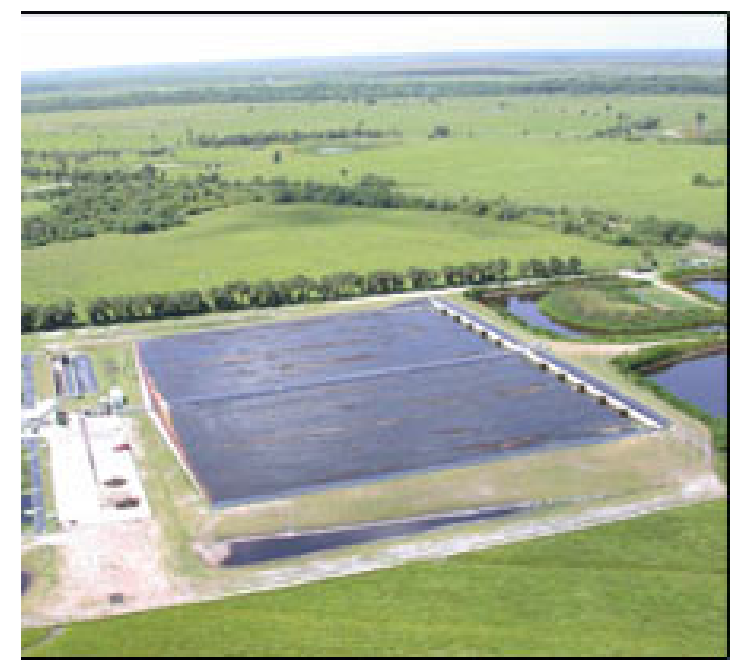

Figure A26. Algal Turf Scrubber ${ }^{\circledR}$ S-154 pilot plant in Central Florida. ${ }^{95}$

- Heterotrophic production of microalgae takes place in conventional fermentation tanks using sugars and O2. Although heterotrophic growth has been promoted as a means to produce biofuels, the primary practitioner of this approach, Solazyme, has focused its business plan on higher value products such as nutraceuticals, cosmaceuticals and food products. Others, including DSM have commercialized heterotrophic algal growth for production of omega-3 fatty acids such as docosahexaenoic acid and eicosopentenoic acid. For the sake of this study, heterotrophic growth will not be considered.

\section{Cultivation Challenges}

There remain significant challenges to each of the cultivation methods which have a direct cost impact on algal biofuel production.

\section{Sustained Algae Cultivation in Open Ponds}

The current technology for mass culture of microalgae is still in its infancy. Only a few strains are currently mass cultured on a large-scale ( $>1$ hectare) and sustained, year-long basis (even if not produced year round). Some experience, in particular from the DOE Aquatic Species Program, suggests that it will be possible to isolate, from suitable natural environments, and screen (with an appropriate protocol) additional strains for mass culture.

The envisioned technology for algal biomass production is based on the production of sufficient inoculum to get an algal culture (re)started whenever required. If re-starts are required too often, the inoculum production effort quickly becomes a major cost, as is the case for commercial Chlorella production, and certainly will be too costly for biofuel production. The ability to reinoculate and resume production within a matter of days is, however, a distinct advantage over terrestrial crops in which a crop loss costs the entire growing cycle (typically a year).

The techniques required to establish a mass culture must first minimize both culture contaminants and algae grazers (rotifers, amoeba, and others) that can cause production ponds to crash. Over an extended period, even a relatively modest advantage in growth rate would allow a

\footnotetext{
${ }^{95}$ http://www.hydromentia.com/Products-Services/Algal-Turf-Scrubber/Product-Documentation/Assets/ATS-Technical-Brochure.pdf
} 
minor contaminant to dominate the culture. Thus, it is imperative that the competitive advantage of any contaminants be reduced. In commercial algae mass culture (aside from Spirulina or Dunaliella, which use selective culture medium) this is achieved by mostly proprietary techniques, but includes limiting nutrient supplies to reduce the ability of the contaminants to grow. Rotifers and other grazers require different approaches, including occasional excursions in pond environmental conditions inimical to these animals. Even if weeds and grazers are successfully combated, there remain the viruses and other "diseases" (lytic bacteria, fungal infections, and others) to which algal cultures will be prone, and about which almost nothing is known. The situation may be compared to early agriculture, only at a microscopic scale and at a very fast tempo. Therefore, the rapid rates at which algal growth, contamination, grazing, infection, and recovery can unfold in a mass culture is a real advantage of these systems; and allows the study of these phenomena in weeks and months, instead of years and decades as with higher crops, as well as allow recovery of the affected cultures in days.

\section{Algae Cultivation in Closed Bioreactors}

Productivities in photobioreactors are limited by solar input, and growth technology cannot alter this limit. Many reports of improved areal productivity refer to the area of the growth vessel for the photobioreactor itself, and these numbers can be extremely high when the reactors are configured vertically. However, vertical photobioreactors must be situated far enough from each other so as to not shade each other. Thus, the basic limitation on areal productivity remains the same for both open ponds and closed photobioreactors.

Surface fouling due to bacteria, other organisms, and, in particular, algae, is one of the major problems encountered with closed photobioreactors. Cleaning the photobioreactors often becomes a major design and operational challenge. Another photobioreactor process issue is the inherent limitation in gas transfer through the closed system boundary. Both CO2 input and O2 evolution must be optimized for maximum productivity, and the lack of ability to be exchanged through the walls of can result in suboptimum concentrations of these gases in the photobioreactor.

\section{Algal Harvesting}

The potential oil yields (gal/acre) for algae are significantly higher than yields of oil seed crops (20 times higher than soybeans). Therefore, less algal biomass is required to produce biodiesel than from other biomass options. Low cost algal harvesting options do not currently exist, but this is an area of significant interest and effort for the private sector and for public-private partnerships such as the major consortium established by DOE, National Alliance for Advanced Biofuels, and Bio-Products.

Harvesting of algal biomass can be accomplished several ways. Attempts in the past have taken advantage of spontaneous settling of the algal cells, without using chemical flocculants. Other mechanisms include the auto flocculation process which depends on the co-precipitation of algal cells with calcium carbonate and other precipitates that form in hard waters subject to high $\mathrm{pH}$. Aside from settling, in some cases the algal biomass will float, either due to buoyancy (e.g., high oil content) or by using a dissolved air floatation process, as is widely used in chemical flocculation. The use of small amounts of chemical flocculants (polymers) to aid in such a process could be cost effective, depending on the amount used. Nevertheless, a significant engineering research effort aimed at developing cost-effective algal harvesting techniques will be 
required. In order to reduce cost and energy inputs, a three-stage harvesting process (flocculation, dissolved air floatation, and centrifugation) has been proposed by NREL (Davis et al. 2012).

\section{Conversion of Algal Biomass to Biofuels}

Interest in algal biomass as a biofuels feedstock has traditionally arisen from the high lipid content in algal cells that are grown under specific conditions (typically nitrogen starvation conditions). The differences between microscopic algal cells and seeds of oil-bearing terrestrial plants demand that different processes be employed for oil recovery. The most likely technology for algal oil recovery, currently in development, involves some form of solvent extraction (though other methods such as mechanical or electrochemical extraction have been proposed). Any process option is likely to be complicated, however, by the high water content of algal biomass. NREL has developed a wet processing of microalgae utilizing low $\mathrm{pH}$, high temperature cell disruption. This process also causes hydrolysis of the algal carbohydrates and precipitation of the proteins. Fractionation of the components into lipid, carbohydrate, and proteins streams can be used for production of valuable coproducts to help drive the overall economics. Once the algal oil is recovered and suitably upgraded, the conversion processes to biodiesel or green diesel are fairly well understood.

Complications may still arise from differences in overall lipid content (i.e., relative levels of triacylglycerols, phospholipids, and glycolipids) that will occur with changes in algal populations and climatic variations. The high inorganic content of algal biomass implies that there will be a cost to supply nutrients, but the apparently high nutrient levels in Salton Sea water (indicated by natural algal blooms) will reduce the need for commercial nutrients. In addition, the potential to convert the unvalorized components of algal biomass to methane via anaerobic digestion will result in the production of nutrient-rich sludge which can be recycled to the algae ponds.

A fairly recent development in algal processing relies on thermochemical processing of wet algal biomass in a process called hydrothermal liquefaction. This process converts all of the algal biomass into "green crude" which can be catalytically converted to fuels. This process is being developed by Sapphire and by Algenol in conjunction with the Pacific Northwest National Laboratory to supply oil refiners with green crude that can be blended with petrocrude for upgrading into transportation fuels and other refinery products.

\section{Commercialization Potential}

The technical challenges discussed represent significant obstacles to the development of economically viable biofuels from algae and until a large-scale system has actually been built and demonstrated, many uncertainties remain. Issues such as pond construction materials, mixing, optimal pond scale, and $\mathrm{CO} 2$ delivery have been considered and even in some cases explored, but definitive answers await detailed and expensive scale-up evaluation. The availability of resources at the Salton Sea under consideration, make it an ideal location to develop such a demonstration facility.

\section{Existing Algae Cultivation Technologies in the Salton Sea}

Synthetic Genomics (SGI) is an algae company with a small (40 acre) research and production facility located 1 mile from the southern tip of the Salton Sea. They are developing processes for 
the production of food and nutritional supplements. The value of protein for nutritional purposes is 3-4 times higher than the value of biofuels and so the path to commercialization can be shorter. SGI anticipates that a commodity product like fuels would require an algae farm of $>1000$ acres with unit ponds in the 5 to 10 acre range. They intend to scale up to a facility of several hundred acres to produce higher value products. They are taking advantage of the high salt concentration in Salton Sea water to grow marine and hypersaline strains of algae, though they noted that algal growth rates tend to decline with higher salt concentrations so productivity can be a problem. Even so, marine strains tend to be more robust than freshwater strains and less prone to pond crashes due to predators or pathogens. They are just as prone to competition with indigenous algal strains which can act as weeds and take over cultivation systems. Small scale production facilities will devote as much as $30 \%$ of the facility area for non-production operations (building, roads, etc.), but this percentage would drop to about $15 \%$ for larger scale production.

\section{Appendix B: Energy Market Analysis}

Market fundamentals will ultimately determine whether new renewable energy projects near the Salton Sea are economically competitive - and if so, whether they are competitive enough to bear the additional load of a Salton Sea restoration tax. This chapter examines the economic competitiveness of Salton Sea renewables in their most likely target markets, California, and Arizona.

The two markets are defined by the magnitude and coherence of their electricity demand, and by the transmission links from the IID balancing authority area. The map in Figure B1 shows the IID BA area and the connecting extra-high voltage (EHV) transmission paths. Historically, almost all of the power on this path across the Colorado River has flowed east to west, consisting mostly of power from the Palo Verde Nuclear Generating Station west of Phoenix supplying urban centers in Southern California. ${ }^{96}$

Nevertheless, the path has begun to accommodate counterflow in the opposite direction, including power from Salton Sea geothermal resources serving utility customers in Arizona. Both SRP and APS have PPAs with geothermal plants in the Salton Sea area. ${ }^{97}$ The large potential for additional counterflow to the east means that in some cases, access to Arizona could be easier than access to the rest of California.

\footnotetext{
${ }^{96}$ Western Electricity Coordinating Council (WECC), Annual Path Data (spreadsheets), various years through 2012, https://www.wecc.biz/Reliability/2012 Path Data. xlsx.

${ }^{97}$ Salt River Project, "SRP taps into super-hot renewable energy resource" (press release), Sept. 17, 2013; Arizona Public Service, Renewable Energy Portfolio (fact sheet), January 2013, https://www.aps.com/en/Documents/pdf/company/RenewableEnergyPort.pdf.
} 


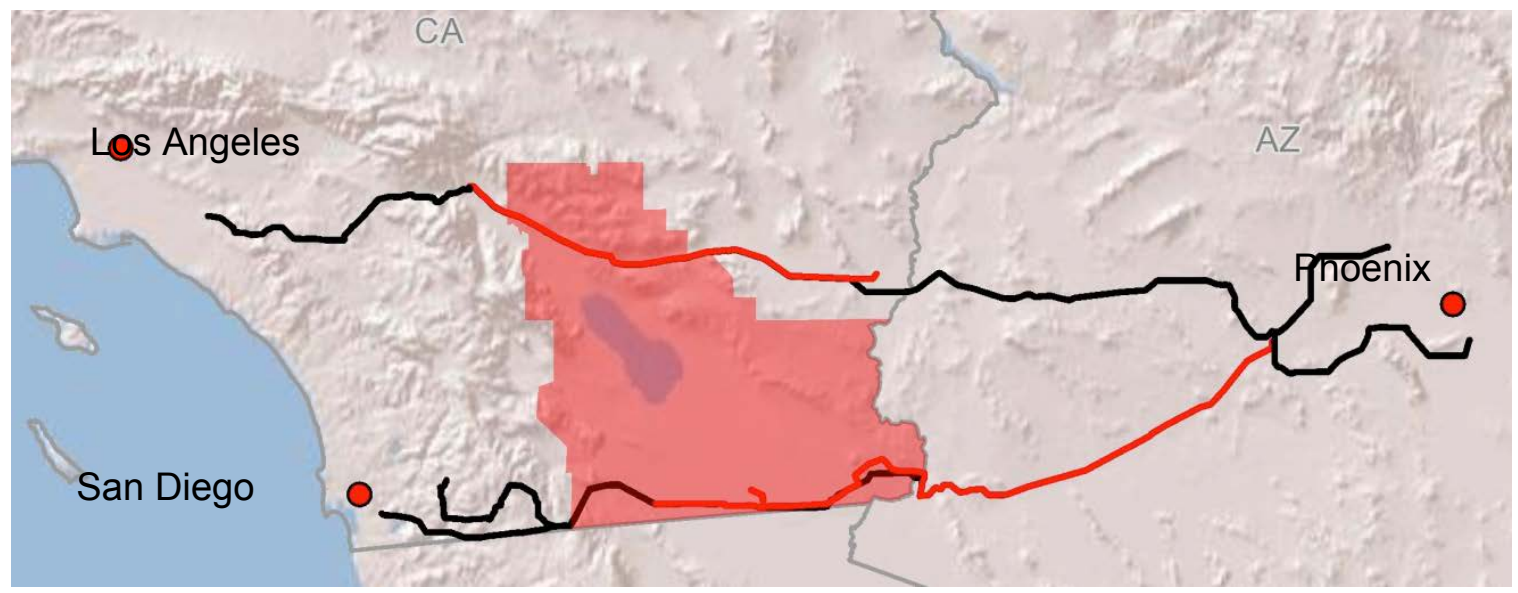

Lines indicate $500 \mathrm{kV}$ transmission to and from IID balancing authority area; red lines indicates planned upgrades.

Figure B1: Imperial Irrigation District with EHV transmission paths. ${ }^{98}$

With respect to market prices, southern California tends to be more lucrative than Arizona. From 2012 to 2014, wholesale power prices in southern California were 24\% higher than prices at the Palo Verde hub near Phoenix. The data was compiled by SNL Energy for day-ahead trades of energy for on-peak delivery. Annual average trading hub prices:

$\begin{array}{cccc} & \text { Palo Verde } & & \frac{\text { SP15 }(\mathrm{S} .}{\text { Cal. })} \\ 2014 & \$ 42.42 & & \$ 52.20 \\ 2013 & \$ 37.66 & & \$ 49.03 \\ 2012 & \$ 29.68 & & \$ 35.30\end{array}$

The analysis detailed below supports the following overall conclusions about the market for Salton Sea renewables.

- Both California and Arizona are likely to see higher demand for renewable resources by 2020 and beyond.

- Salton Sea renewables face different tradeoffs competing in the two markets. While high power prices make the California market more lucrative, there are many choices for new renewable development, even for baseload renewables such as geothermal. In Arizona, however, there are few practical alternatives to Salton Sea geothermal for renewable baseload. Power prices tend to be lower in Arizona than in California, so Salton Sea geothermal will likely continue to be an above-cost resource for a longer period.

- Salton Sea renewables have no discernible headroom for bearing an additional cost earmarked for Salton Sea reclamation. In California, for example, adding $\$ 5 / \mathrm{MWh}$ on top of the cost new Salton Sea geothermal projects could result in an additional $2 \%$ to $3 \%$ of the supply pool being economically superior. Although there is not currently sufficient economic headroom for a power production tax, policies favorable to renewable energy (streamlined permitting, increased RPS targets) could create a unique benefit to development within the region that might offset the additional tax.

\footnotetext{
${ }^{98}$ Western Electricity Coordinating Council (WECC), Annual Path Data (spreadsheets), various years through 2012, https://www.wecc.biz/Reliability/2012 Path Data. xlsx.
} 
This analysis begins with the supply side of the equation, focusing the cost of Salton Sea geothermal and solar resources relative to the cost of competing resources built elsewhere. It projects current technology costs into the near future, drawing on most recent information to estimate technology cost trajectories.

Examining the demand side begins with RPS policies in California and Arizona, including the recently-passed 50\% RPS law, which was passed as of the publication of this report. The analysis takes account of existing development and new procurements identified in utility integrated resource plans (IRPs) to estimate the likely residual demand for additional renewables related to RPS requirements. Beyond 2030, there is a potential for greater demand for renewable energy demand driven by California policy, such as the executive order for $80 \%$ GHG reductions below 1990 levels by 2050, as well as California AB-32.

The analysis then examines transmission and other infrastructure issues that could affect the ability of Salton Sea renewables to reach potential markets. It reviews current transmission plans by CAISO and utilities, identifies transmission development obstacles, and analyses transmission capacity that would be required to export Salton Sea renewables to various markets.

All supply options for both markets are assumed to be on an even regulatory footing-i.e., there is no special mandate on any utility to procure Salton Sea renewables as opposed to generically sourced renewables.

\section{Supply Trends}

We construct the supply picture as follows.

- Identify the renewable resources most likely to compete in large volumes for the two markets

- Establish plausible benchmark points for comparing the cost of various renewable energy options

- Compare the competitiveness of the Salton Sea area's prevalent renewable optionsgeothermal and solar - against the same technologies from different geographic areas

- Project current renewable technology costs forward under a plausible range of assumptions, and assess how each technology tends to perform against the combined cycle natural gas $(\mathrm{CCNG})$ benchmark

- Examine the competitive "headroom" of Salton Sea renewables (where "headroom" refers to the margin between the untaxed cost of Salton Sea renewables and the price point at which the resource would become uncompetitive).

This analysis necessarily deals with costs projected out to 2030 , which, due to the rapid pace of cost and technology innovations in the renewable energy industry, are highly uncertain. To account for the uncertainty inherent in such projections for solar technologies, wind technologies, and natural gas, this analysis characterizes future cost as a plausible range, and not as a single value. This could lead to analytical outcomes that appear ambiguous, but only because they pragmatically reflect uncertainty about future costs. 
This analysis relies on two tools for examining supply: NREL's Annual Technology Baseline and Standard Scenarios ${ }^{99}$, an ongoing project to provide annual updates for technology cost and performance based on current market intelligence by NREL and the DOE; as well as the calculator developed by CPUC to evaluate resource portfolios for compliance with the state's RPS.

The Annual Technology Baseline provides annual updates for technology cost and performance based on current market intelligence by NREL and the DOE. ${ }^{100}$ It also uses the most current analyses to track cost trajectories into the future.

The RPS Calculator includes estimates of undeveloped renewable energy potential based on a number of detailed resource assessments that screened resources based on various land use and performance criteria. ${ }^{101}$ In this analysis, the RPS Calculator is used primarily to evaluate the competitiveness of Salton Sea renewables relative to other yet-undeveloped renewable energy options likely to be available for future demand in California. This part of the analysis combines a technology's cost with the value it brings to the market: the value of energy it would replace and the value of its contribution to system reliability. Conclusions about the relative competitiveness of Salton Sea renewables are based on where they fall on the value-ordered supply curve. The farther up a resource is, the more vulnerable it is to being dominated economically by other resource options.

For purposes of this analysis, the RPS Calculator's Imperial renewable energy zone is geographically equivalent to the Salton Sea study area and the IID balancing authority area. Geothermal and solar are the largest-volume renewable resources in Imperial zone, and these are assumed to be the primary resources from the Salton Sea area that would compete in the Arizona and California markets. ${ }^{102}$

\section{Resources Competing for California}

The California market for renewable power is large and has a diverse set of resource options. Table B1 shows the undeveloped and potential new resources included in the RPS Calculator, expressed as GWh of energy per year.

Most of California's undeveloped geothermal potential is in the Imperial zone. Apart from these resources, the largest amounts of new geothermal potential in the RPS Calculator is located elsewhere in California or in Nevada.

\footnotetext{
${ }^{99}$ NREL, Annual Technology Baseline and Standard Scenarios (web page, http://www.nrel.gov/analysis/ data_tech_baseline.html).

${ }^{100}$ NREL, Annual Technology Baseline and Standard Scenarios (web page, http://www.nrel.gov/analysis/ data_tech_baseline.html)

${ }^{101}$ California Public Utility Commission, RPS Proceeding Materials version 6.0+ (web page, http://www.cpuc.ca.gov/PUC/energy/Renewables/RPS+Proceeding+Materials+Version+6.htm

${ }^{102}$ About $10 \%$ of the renewable resources already developed in the Salton Sea area actually interconnected directly with CAISO rather than IID. For the demand and supply sections of this analysis, "Salton Sea area," "Imperial zone," and "IID" are geographic references that do not distinguish between interconnection with IID and with CAISO.
} 
Table B1: Undeveloped Potential Resources in the RPS Calculator (GWh per year)

\begin{tabular}{|l|r|r|}
\hline & All available & Imperial Zone \\
\hline Large Solar PV (fixed tilt)* & 404,016 & 22,244 \\
\hline Wind & 212,277 & 1,008 \\
\hline Geothermal & 39,294 & 10,681 \\
\hline Distributed Solar PV & 30,705 & 290 \\
\hline Biomass & 29,834 & 24,515 \\
\hline Hydro & 1,085 & \\
\hline Biogas & & \\
\hline
\end{tabular}

*For the purposes of this table, we use fixed-tilt photovoltaics (PV) as indicative of all utility-scale solar potential, with the understanding that a specific site could be developed with tracking PV or thermal concentrating solar power (CSP).

(Source: CPUC RPS Calculator)

Southern California, Arizona, and southern Nevada have solar photovoltaic (PV) resources capable of producing with high capacity factors. The RPS Calculator places about $69 \%$ of the potential new capacity in California, with the most of remainder divided between Arizona (12\%) and Nevada (11\%). As a general rule, CSP can be a viable alternative for the flattest areas with good solar potential.

Wind accounts for $29 \%$ of potential new resources, with most of it spread among California, Wyoming, New Mexico and British Columbia. The resources in Wyoming and New Mexico indicate higher capacity factors than California's remaining undeveloped wind resources, and thus could be competitive even after taking into account long-distance transmission costs (Corbus et al. 2014).

Based on the volume of undeveloped potential, Salton Sea resources' most likely competitors in the California market include:

- For baseload renewable power production: geothermal resources from Nevada and elsewhere in California.

- For variable generation:

○ utility-scale PV from Nevada, Arizona, and elsewhere in California

o wind from Wyoming.

\section{Resources Competing for Arizona}

Solar is Arizona's most prevalent indigenous renewable resource. After screening out areas that are environmentally sensitive or difficult to develop, the state has estimated 47,000 $\mathrm{GWh} /$ year of solar potential, all with very high capacity factors and relatively low cost per MWh of energy generated.

Wind is also a part of the Arizona renewables market, but its characteristics could change significantly with transmission expansion from New Mexico. The state has some wind potential in the north central and northwest part of the state. New Mexico's wind potential is larger, however, and has some of the highest capacity factors in the West. Two of Arizona's major 
utilities - Salt River Project and Tucson Electric Power - are partners in a major transmission project that would enable delivery of up to 3,000 MW of New Mexico wind power to Phoenix and other markets in the state. ${ }^{103}$

Salton Sea geothermal projects may also be competitive in Arizona as baseload renewable power, however, as SRP in Arizona is a current buyer of geothermal power from the Salton Sea's 50 MW Hudson Ranch plant. For this analysis, the large-volume resources assumed most likely to compete with Salton Sea renewables in the Arizona market are in-state solar and wind power, and New Mexico wind power.

\section{Benchmarking Costs}

To understand how Salton Sea renewables might fare in the open market against competing supplies, we construct a cost benchmark using a hypothetical combined cycle natural gas generator (CCNG) built in California sometime between 2015 and 2030, operated as a baseload resource. Comparing renewable energy cost trends against this benchmark provides one indicator of the technology's economic strength. It also provides a market context for comparing two renewable options. For example, one renewable project's cost advantage over another might diminish in importance if both projects are substantially above the benchmark.

Figure B2 shows the CCNG cost benchmark used in this analysis. It is based on the following assumptions:

- The overnight capital cost of a newly built CCNG is $\$ 1,200 / \mathrm{kW}$. We add $\$ 55 / \mathrm{kW}$ to this amount for dry-cooled configurations. This adder accommodates compliance with rules governing the use of once-through cooling, and it internalizes future operational risks due to the possibility of extended drought that could limit the availability of water for cooling.

- The CCNG is operated as a baseload plant, with a capacity factor of $85 \%$.

- Greenhouse gas mitigation costs accelerate from a 2012 level of $\$ 10 /$ metric ton at an inflation-adjusted rate of $5 \%$ per year.

- Natural gas supply costs are variable. Future changes in gas costs could result in combined cycle generation costs well outside the stated assumptions.

${ }^{103}$ U.S. Bureau of Land Management, Record of Decision for the SunZia Southwest Transmission Project, January 2015 (http://www.blm.gov/nm/st/en/prog/more/lands_realty/sunzia_southwest_transmission.html). 
Source: All-in costs estimated by NREL. Upper and lower bounds are based on the forecasted price of natural gas under two scenarios used by EIA in its 2014 Annual Energy Outlook. The high price scenario assumes lower natural gas supply-specifically, that the ultimate recovery per shale gas, tight gas, and tight oil well is $50 \%$ lower than in EIA's reference case. The low price scenario assumes higher natural gas supply-specifically, that the ultimate recovery per shale gas, tight gas, and tight oil well is 50\% higher and well spacing is $50 \%$ lower (or the number of wells left to be drilled is $100 \%$ higher) than in EIA's reference case. We assume a CCNG capital cost of $\$ 1,200 / \mathrm{kW}$, plus an adder of $\$ 55 / \mathrm{kW}$ for dry cooling. Variable costs include a greenhouse gas offset adder of $\$ 10 / \mathrm{metric}$ ton, escalating from 2012 at a real annual rate of $5 \%$.

Figure B2: Cost benchmark based on new cycle natural gas generator.

The potential variation in a CCNG's levelized cost of energy (LCOE) is captured in the potential variation in the price of natural gas. This benchmark uses forecasts by the Energy Information Administration (EIA) to represent scenarios for high gas prices and low gas prices. The high price scenario assumes lower natural gas supply — specifically, that the ultimate recovery per shale gas, tight gas, and tight oil well is 50\% lower than in EIA's reference case for its 2014 Annual Energy Outlook. The low price scenario assumes higher natural gas supplyspecifically, that the ultimate recovery per shale gas, tight gas, and tight oil well is $50 \%$ higher and that well spacing is $50 \%$ lower (that is, the number of wells left to be drilled is $100 \%$ higher) than in EIA's reference case.

Using these assumptions, the plausible cost range for a new CCNG built in 2015 is $\$ 72 / \mathrm{MWh}$ to $\$ 86 / \mathrm{MWh}$ (in constant 2015 dollars). This band increases to a plausible range of $\$ 81 / \mathrm{MWh}$ to $\$ 119 / \mathrm{MWh}$ in 2030. The implication is that renewable technologies with future costs falling within this band have the best chance of being economically competitive with a newly built CCNG plant.

\section{Current Costs}

Table B2 shows the current technology costs assumed for this analysis. They begin with costs developed for NREL's Annual Technology Baseline (v6.0). Because this analysis focuses on a specific geography, base costs are adjusted using state multipliers developed for the Western Electricity Coordinating Council. ${ }^{104}$ These multipliers account for general differences in labor

\footnotetext{
${ }^{104}$ Energy and Environmental Economics, Capital Cost Review of Power Generation Technologies (final report and recommendations approved by WECC), March 2014, Table 33 (https://www.wecc.biz/Reliability/2014_TEPPC_Generation_CapCost_Report_E3.pdf).
} 
costs, taxes, right-of-way values, and other factors that affect project costs. This estimate follows the methodology used by NREL to estimate transmission costs for Wyoming wind power:

$$
\frac{A R}{M W \times C F \times 8,760 \times(1-\text { loss })}
$$

where $A R$ is the annual revenue requirement for the transmission project (dollars), $M W$ is the transmission project's total transfer capability (megawatts), $C F$ is the generator's annual capacity factor (\%), and loss is the transmission project's line loss factor (\%). Total transmission development costs are assumed to be $145 \%$ of capital costs, annualized at $7.7 \%$ over 50 years. Assumed capital cost for a $500 \mathrm{kV}$ line from Wyoming to a CAISO interconnection is $\$ 3$ billion; assumed capital cost for a $500 \mathrm{kV}$ line from New Mexico to Arizona is \$2 billion.

Of note, however, is that both these options depend on EHV transmission projects that are still in the permitting phase and do not yet exist.

Table B2. Renewable Technology Cost Assumptions (2015 dollars)

\begin{tabular}{|c|c|c|c|c|}
\hline & & $\begin{array}{l}\text { Capital Cost }{ }^{\mathrm{a}} \\
(\$ / \mathbf{k W})\end{array}$ & $\begin{array}{l}\text { Fixed O\&. }{ }^{\mathrm{a}} \\
(\$ / \mathbf{k} W-y r)\end{array}$ & $\begin{array}{l}\text { LCOE } \\
\text { (\$/MWh) }\end{array}$ \\
\hline \multirow{2}{*}{$\begin{array}{l}\text { Geothermal } \\
\text { (flash) }\end{array}$} & in California & $\$ 7,088$ & $\$ 368$ & $\$ 128$ \\
\hline & in Nevada & $\$ 6,487$ & $\$ 337$ & $\$ 117$ \\
\hline \multirow{2}{*}{$\begin{array}{l}\text { Geothermal } \\
\text { (binary) }\end{array}$} & in California & $\$ 7,442$ & $\$ 236$ & $\$ 134$ \\
\hline & in Nevada & $\$ 6,811$ & $\$ 216$ & $\$ 122$ \\
\hline \multirow{3}{*}{$\begin{array}{l}\text { Solar PV } \\
\text { (1-axis tracking) }\end{array}$} & in California & $\$ 3,670$ & $\$ 25$ & $\$ 127$ \\
\hline & in Nevada & $\$ 3,359$ & $\$ 22$ & $\$ 116$ \\
\hline & in Arizona & $\$ 2,986$ & $\$ 21$ & $\$ 103$ \\
\hline \multirow{3}{*}{$\begin{array}{l}\text { Solar thermal (CSP) } \\
\text { (12 hours storage) }\end{array}$} & in California & $\$ 10,168$ & $\$ 89$ & $\$ 217$ \\
\hline & in Nevada & $\$ 9,306$ & $\$ 82$ & $\$ 198$ \\
\hline & in Arizona & $\$ 8,272$ & $\$ 73$ & $\$ 176$ \\
\hline \multirow{3}{*}{ Wind } & in California & $\$ 2,091$ & $\$ 60$ & $\$ 97$ \\
\hline & in Wyoming & $\$ 1,481$ & $\$ 46$ & $\$ 76^{\mathrm{C}}$ \\
\hline & in New Mexico & $\$ 1,563$ & $\$ 48$ & $\$ 74^{\mathrm{a}}$ \\
\hline
\end{tabular}

a'Base costs are from NREL's 2015 Annual Technology Baseline, v6.0, with the following WECC regional adjustment multipliers cited in footnote 11:

$\begin{array}{ll}\text { California: } & 1.18 \\ \text { Arizona: } & 0.96 \\ \text { New Mexico: } & 0.95 \\ \text { Nevada: } & 1.08 \\ \text { Wyoming: } & 0.90\end{array}$

\footnotetext{
${ }^{\mathrm{b}}$ Solar $\mathrm{PV}$ costs are per $\mathrm{kW}_{\mathrm{AC}}$, assuming DC-to-AC inverter loading multiplier of 1.3. Includes long-distance EHV transmission cost of \$29/MWh, assuming delivery to California.

${ }^{d}$ Includes long-distance EHV transmission cost of $\$ 22 / \mathrm{MWh}$, assuming delivery to Arizona.
}

For geothermal and solar PV, the LCOE tends to be lower if the projects are sited in Nevada rather than California, which economically disadvantages Salton Sea renewables. We estimate 
that Nevada geothermal and solar resources could have a $9 \%$ cost advantage over the same technologies built near the Salton Sea.

Apart from wind power from Wyoming and New Mexico, the resource with the lowest levelized cost is solar PV in Arizona. High productivity and lower project costs tend to give Arizona solar PV a 19\% cost advantage over Salton Sea renewables, making it economically stronger in its home market. It is still currently more expensive than the CCNG benchmark, but as described in the next section, this could change within a few years.

\section{Cost Trajectories for Major Renewable Energy Technologies}

Tracking cost trajectories helps to understand how the technology's market competitiveness could change over time, relative to the CCNG cost benchmarks. The technology's all-in costs are measured by its LCOE at five-year increments based on trends in capital costs and fixed operation and maintenance (O\&M) costs. These costs trajectories do not include geographic adjustments, because the purpose of this part of the analysis is to reflect changes over time, such as technology or cost innovations that are assumed to have an equivalent effect on new projects regardless of where they might be built. For solar technologies, the trajectories shown in the figures below are likely to play out similarly for any geography along the same latitude, due to similar insolation across the southwest. Further, it is likely that the current between-state differences, such as the cost of labor, will hold as these technology trajectories change over time.

Federal tax incentives are calculated as part of the LCOE only according to their provisions under current law. Otherwise, LCOE estimates for future years do not include the effect of the investment tax credit or the production tax credit.

Figures B3 through B5 illustrate the cost trends affecting Salton Sea renewables and their competing resources, benchmarked against natural gas. For each technology, LCOE is based on a 20 -year cost recovery, $50 \%$ debt and $50 \%$ equity, and a weighted average capital cost of $8.9 \%$.

Geothermal development costs vary spatially based on site-specific conditions, and the differences can be significant. Figure B3 therefore depicts geothermal technology costs as a $\pm 10 \%$ variation from the generic values used in the Annual Technology Baseline This captures a significant portion of the locational cost variation seen in today's geothermal market. Salton Sea geothermal tends to be in the higher part of this range due to the fact that the water from the underground heat reservoirs is briny, thus requiring more corrosion-resistant materials.

Geothermal costs overall are not expected to change significantly. Consequently, its projected time of economic opportunity is largely a function of how quickly the CCNG benchmark rises. These trends suggest a crossover point beginning around 2025 for the least-cost geothermal projects, expanding to the rest of the industry around 2030. However, the true cost of baseload geothermal, as compared to intermittent solar and its needed redundant backup, is still unresolved. The additional value of this baseload geothermal capacity to energy grids may make this technology more competitive over time, despite currently projected higher costs.

In contrast with geothermal, costs for new utility-scale solar development have been falling so rapidly that the uncertainty concerns the pace at which the reductions will continue into the 
future. Thus the gaps between low and high cost projections shown in Figure B4 are relatively small today but tend to increase over time.

Utility-scale solar PV appears to be trending toward a period of increasing economic opportunity in California and the Southwest around 2020 if not sooner. Concentrating solar power (CSP) is starting at a much higher cost point, and is more likely to encounter its period of economic opportunity much later.

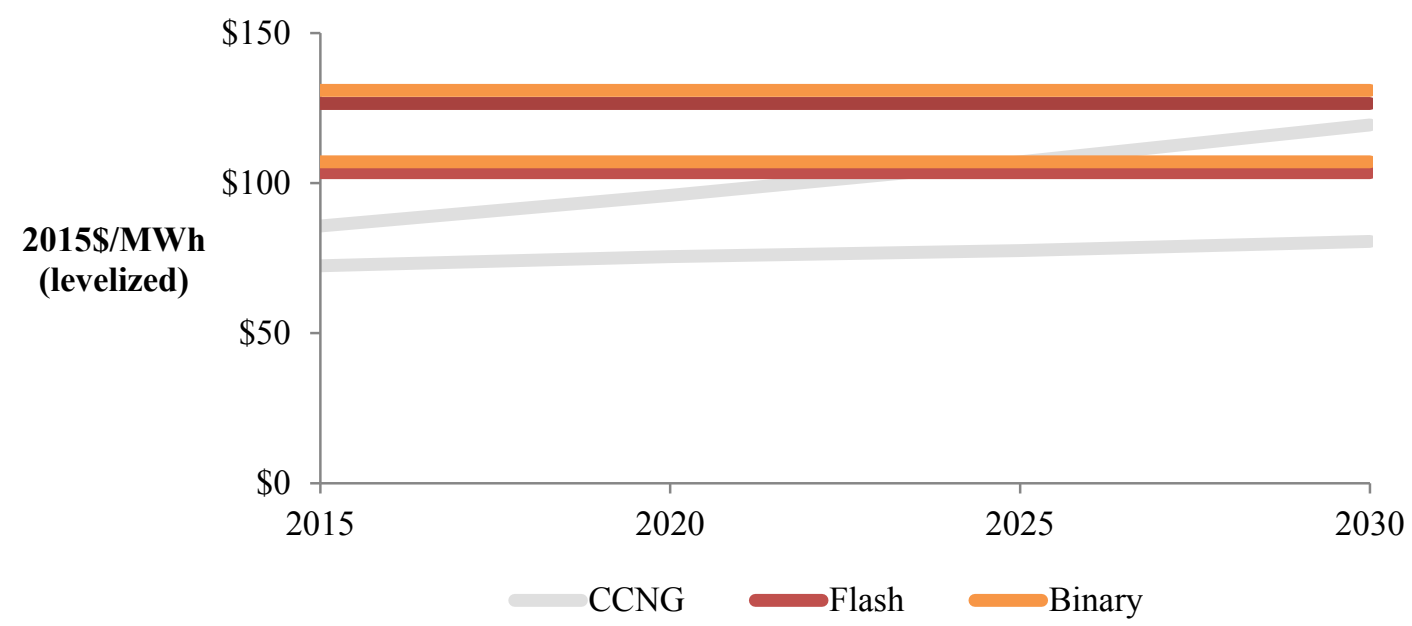

High and low projections are based on NREL Annual Technology Baseline, $\pm 10 \%$ to account for potential projectspecific variations. Gray lines indicate CCNG projected.

Figure B3: Geothermal cost trajectories.

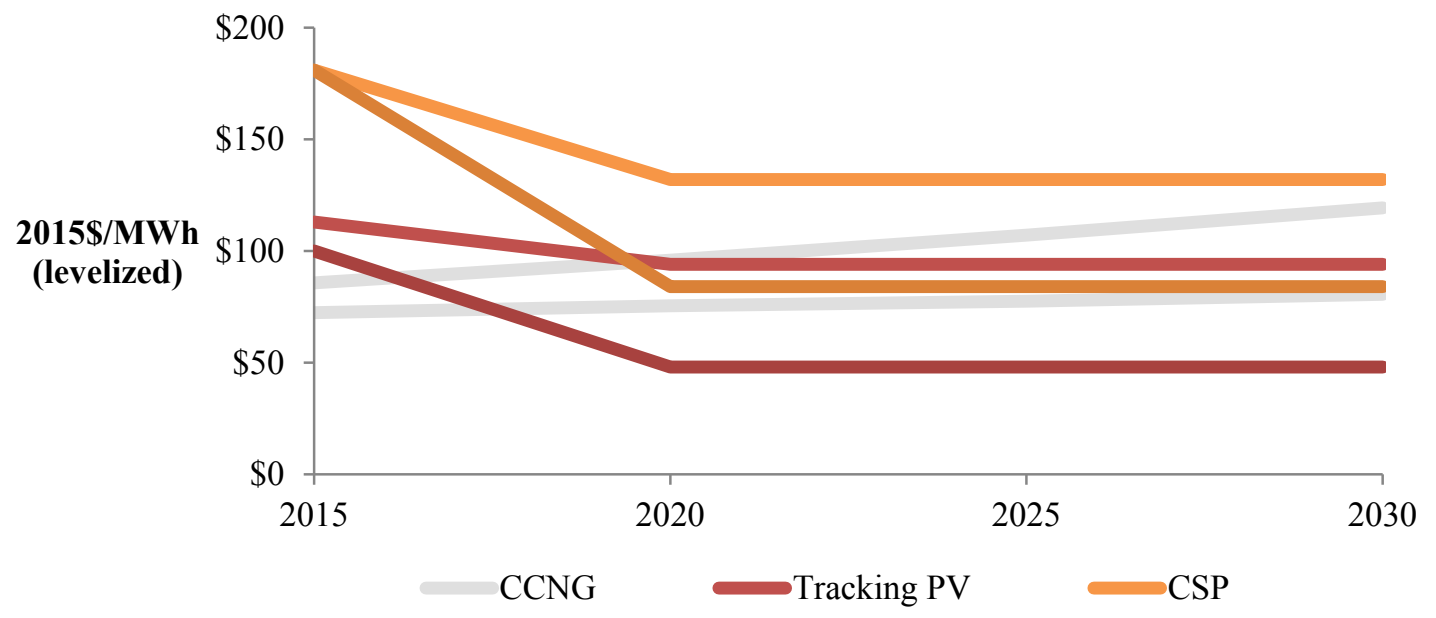

Figure B4: Utility-scale solar cost trajectories. 


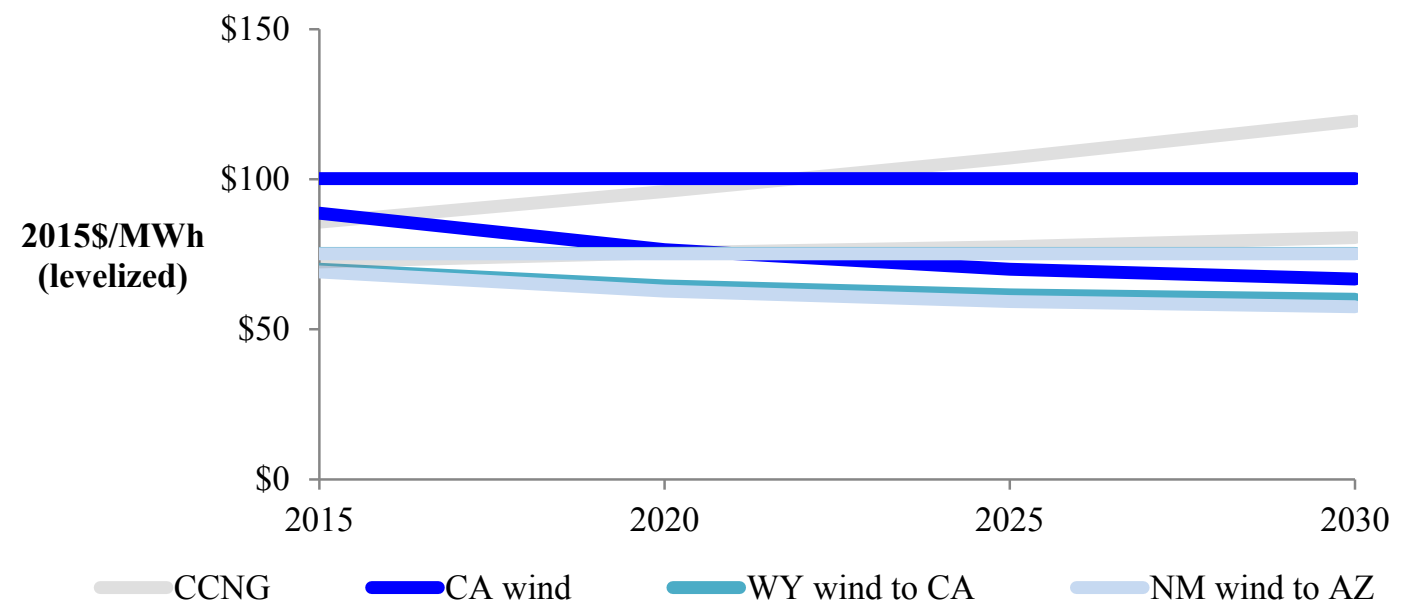

Wyoming wind to California includes a $\$ 29 / \mathrm{MWh}$ adder to account for bulk transmission costs to California. New Mexico wind to Arizona includes a \$22/MWh adder to account for bulk transmission costs to Arizona.

Figure B5: Wind cost trajectories.

Up to now, wind has been the most cost-competitive renewable technology relative to CCNG. Most of the sites in California with the highest capacity factors have already been developed, however, leaving undeveloped areas where capacity factors tend to be lower. The cost trends for California wind resources shown in Figure B5 are based on the use of low wind speed turbines (higher towers and larger rotor diameters) and capacity factors of around $32 \%$.

For Salton Sea resources, however, the economic competition from wind in the California market is most likely to come from Wyoming, where wind is more consistent and capacity factors are exceptionally high (around 49\%). While the LCOE for Wyoming wind is low at the busbar, getting the power to California requires additional investments in EHV transmission. In the Arizona market, the economic competition from wind resources is most likely to come from New Mexico, which like Wyoming has a large amount of undeveloped resources with potentially high capacity factors. Costs declines are expected to continue, although at a slower pace than for solar PV.

Technical comparisons between technologies will often use LCOE as a metric because it controls for factors that are impossible to represent consistently and systematically. LCOE can be calculated with or without incentives such as the investment tax credit (ITC), flexibility that can facilitate cross-technology comparisons of underlying cost trends. Inputs are applied in a uniform manner, and factors that are site-specific such as insolation and local taxes can be captured in an objective and nondiscriminatory manner. LCOE inputs include, among other factors:

- market cost of panels, inverters, and other equipment related to production

- cost of land and site development

- applicable state and local taxes

- site insolation (raw kilowatts of sunshine per square meter of land, averaged over a typical year) 
- the cost of capital (debt, equity, and the ratio between debt and equity)

- the rate of degradation in the equipment's productive capacity

- the number of years over which costs are to be recovered

What LCOE does not capture is the project-specific deal-making that ultimately leads to a PPA. For example, a purchaser may have a strong preference for low prices early in the contract term. This could lead to a PPA with a discounted first-year price, combined with an escalation clause that increases the price slightly each year. Deal provisions, such as: escalation rate, $30 \%$ ITC, term length, state income and sales tax rates, project financing, and additional grid services can all result in a disparity between the LCOE and ultimate PPA price of a technology.

\section{Headroom}

To test economic headroom, we measure how a hypothetical tax might affect the competitive position of Salton Sea renewables in the overall supply curve for potential new resources serving California. This "tax" represents additional revenue requirements placed on a new project that might be earmarked for financing Salton Sea reclamation efforts.

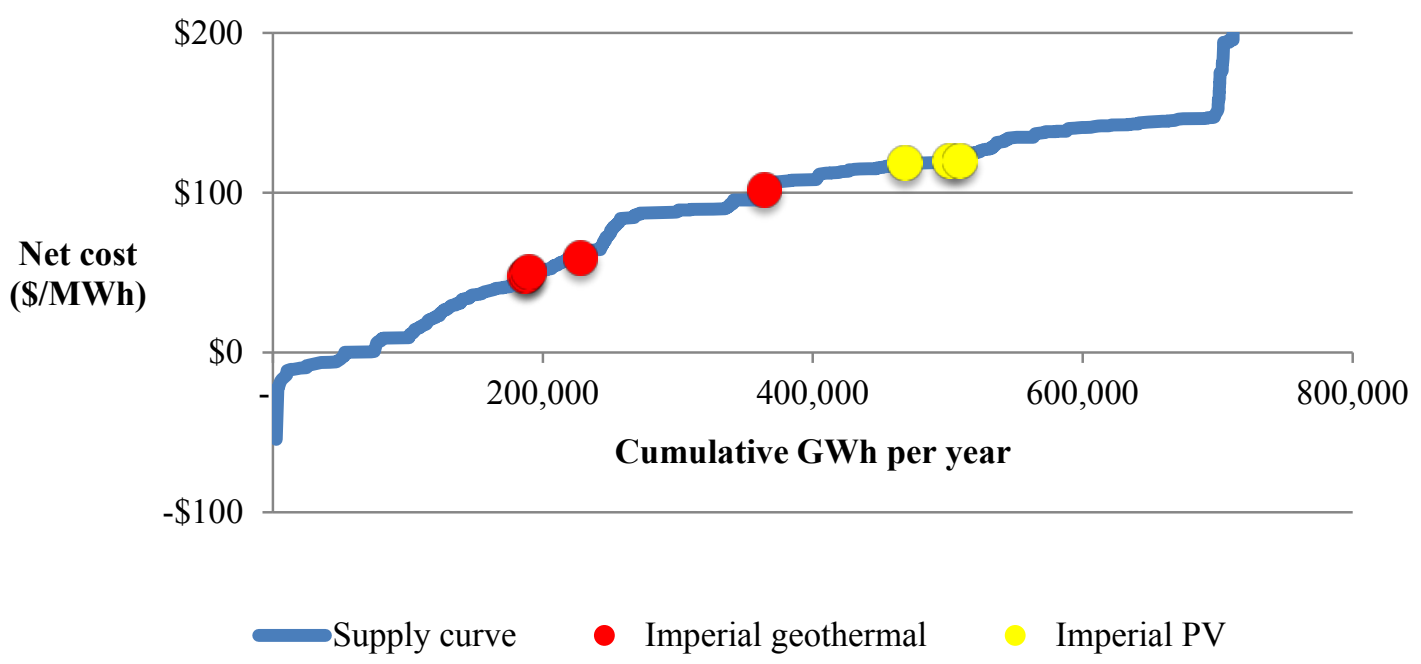

Source: CPUC RSP Calculator

\section{Figure B6: Net cost of potential new resources included in the RPS calculator (Point estimates of the range of net costs.}

Figure B6 shows the undeveloped resources included in the CPUC Calculator, ordered by the estimated net cost of each potential development. "Net cost" is calculated as the project's estimated first-year PPA price, minus the forecasted price of energy, minus the capacity value (how the project would keep the grid stable). Solar has a lower capacity value than geothermal because it is more variable and less controllable. Each point on the curve indicates how much potential generation exists at or below a given level of net cost. The net cost figures indicated in Figure B6 differ from the LCOE's summarized in the executive summary and the previous cost trajectories section due to their inclusion of numerous market factors such as transmission costs, capacity value, and market value of the energy provided. The LCOE calculations intentionally 
exclude variable market factors and incentives such as the investment tax credit, in order to establish a cost baseline for the technologies under review.

Figure B6 suggests that the total supply curve for California comprises more than $700,000 \mathrm{GWh}$ per year worth of renewable capacity. The amount of future demand that might ultimately be placed on this supply is subject to many variables, but one plausible indicator of the magnitude of demand is the effect of increasing the California RPS from 33\% to 50\%. The difference between the two targets, based on total retail electric sales in the state for 2013 and 2014, amounts to around 44,000 GWh annually. ${ }^{105} \mathrm{~A}$ companion indicator is the additional amount of renewables selected by the RPS Calculator when modeling a 50\% RPS, which is about 74,000 GWh per year more than when modeling a 33\% RPS.

These two indicators suggest that demand for new renewables in California is unlikely to reach the higher-cost segments of the supply curve, even if demand is driven further beyond the 50\% RPS target beyond 2030. Even among projects with lower net costs, competition is likely to be strong.

Salton Sea's least-cost, highest-value geothermal ranks near the 25th percentile of the supply curve, meaning its net cost is lower than $75 \%$ of all other options. The area's solar resources are further up the supply curve. The PV cost trends indicated in Figure B4 could lead to an overall improvement over time, but this advantage would accrue similarly to all other solar resources, which in total constitute more than half of the overall supply curve.

If new geothermal were to carry an additional $\$ 5 / \mathrm{MWh}$ burden to help finance Salton Sea reclamation, its competitive position on the supply curve would slip by 2 to 3 percentage points. That is, an additional $2 \%$ to $3 \%$ of the potential supply could become economically superior. This shift might not be significant under scarcity conditions, but it could be a significant handicap in a market characterized by large surpluses.

Put another way, if total demand amounts to around $10 \%$ to $15 \%$ of total supply, resources near the 25 th supply percentile will already be facing intensely competitive conditions where even a small loss of position could be significant.

The area's best solar resources — which already tend to be in the most costly half of the overall supply curve-would slip by about 7 percentage points.

\section{Demand Drivers: California}

California has implemented two keystone policies promoting the development of a cleaner economy and lower electric utility emissions: the California Global Warming Solutions Act (Assembly Bill 32); and an ambitious RPS. These policies have incentivized renewable generation expansion across the state. The CARB recently published its updated AB 32 compliance plan, which calls for near zero emissions from the electric utility sector by 2050 . In addition, Gov. Jerry Brown has directed the CPUC to assess pathways for increasing the state's RPS.

\footnotetext{
${ }^{105}$ These calculations are for general benchmarking purposes only and are not RPS demand forecasts. They do not account for new resources needed to meet the $33 \%$ RPS or for replacement needs that arise from the retirement of older renewable facilities.
} 
The state has enacted other policies to support these statutory goals, including:

- A preferred resources procurement strategy

- The prohibition on conventional coal to serve as a baseload resource

- A battery storage mandate (to counteract the potential reliability concerns associated with expanding renewable generation).

Another key policy not directly associated with carbon reduction is California's requirement that existing power plants reduce water consumption, particularly through restricting the use of oncethrough cooling for thermal generation. This complicates the reliability picture because of the resulting retirement of existing generation and the potential for further retirements.

\section{Renewables Portfolio Standard}

One of the major drivers of carbon emission reductions in California has been the implementation of the state's RPS. Initially enacted in $2002,{ }^{106}$ California has since amended the RPS twice in $2006^{107}$ and in 2011 . The current RPS requires all electricity providers to achieve $33 \%$ renewable energy generation by $2020 .{ }^{108}$ In 2013, California enacted Assembly Bill 327 granting the CPUC authority to expand the state's RPS through rulemaking. ${ }^{109}$ The CPUC has an ongoing rulemaking that is in part focused on evaluating the expansion of the RPS program beyond the $33 \%$ target, ${ }^{110}$ and as of the publication of this report, a $50 \%$ RPS target was recently passed into law.

California's current 33\% RPS has three compliance periods. The first culminated at the end of 2013, when utilities were required to procure renewables in amounts no less than $20 \%$ of retail sales. Procurements must reach $25 \%$ by the end of 2016 , and $33 \%$ by the end of $2020 .^{111}$

In 2013, all the state's utilities were 99\% in compliance with RPS requirements. ${ }^{112}$ The CPUC expects that the state's investor-owned utilities (IOU) will meet the $25 \%$ target in 2016 based on existing and planned projects, but meeting the 2020 goal will require significantly more renewable generation over that which is already planned. ${ }^{113}$

California utilities can procure renewable generation from any location within the WECC provided they are consistent with the CPUC's three portfolio content categories ${ }^{114}$ including:

- Category 1: qualifying renewable generation delivered to, or serving, a California balancing authority, without substituting electricity from another source (not less than $75 \%$ of procurements towards 2020 compliance).

\footnotetext{
${ }^{106}$ See bill here: http://www.energy.ca.gov/portfolio/documents/documents/SB1078.PDF.

${ }^{107}$ See bill here: http://www.leginfo.ca.gov/pub/05-06/bill/sen/sb_0101-0150/sb_107_bill_20060926 chaptered.pdf.

${ }^{108}$ See bill here: http://www.leginfo.ca.gov/pub/11-12/bill/sen/sb 0001-0050/sbx1_2 bill 20110412 chaptered.pdf.

${ }^{109}$ See bill here: http://leginfo.legislature.ca.gov/faces/billNavClient.xhtml?bill_id=201320140AB327\&search_keywords.

${ }^{110} \mathrm{http}: / /$ delaps 1. cpuc.ca.gov/CPUCProceedingLookup/f? $\mathrm{p}=401: 56: 3574229083682::$ NO:RP,57,RIR:P5 PROCEEDING SELECT:R1105005.

$111 \mathrm{http}: / /$ www.dsireusa.org/incentives/incentive.cfm? Incentive Code $=$ CA25R\&ee $=1$.

112 http://emp.lbl.gov/sites/all/files/RPS\%20Compliance\%20Data October\%202014 0.xlsx.

${ }_{113}$ This figure can be found on page 4: http://www.cpuc.ca.gov/NR/rdonlyres/CA15A2A8-234D-4FB4-BE41-

05409E8F6316/0/2014Q3RPSReportFinal.pdf.

${ }^{114}$ http://www.cpuc.ca.gov/PUC/energy/Renewables/hot/33RPSProcurementRules.htm.
} 
- Category 2: qualifying renewable generation delivered to a California balancing authority, after being firmed and shaped by another source (not more than $25 \%$ of procurements towards 2020 compliance).

- Category 3: qualifying renewable generation that is not covered under Category 1 or 2, such as unbundled renewable energy credits (not more than $10 \%$ of procurements towards 2020 compliance).

These procurement requirements limit but do not preclude the potential for some out-of-state renewable providers to serve California's RPS requirements. ${ }^{115}$ In 2013, out-of-state renewable generation accounted for about $20 \%$ of California's RPS-eligible generation. ${ }^{116}$

CAISO and PacifiCorp currently operate an energy imbalance market (EIM), which is expected to more cost effectively (Milligan et al. 2013) integrate regional renewable facilities into the system. NV Energy is scheduled to join the EIM in 2015; Puget Sound Energy in Washington is also studying the possible affiliation. If the EIM is successful as a tool for integrating wind and other variable renewables, it could to some extent reduce reliability advantage otherwise enjoyed by geothermal resources from the Salton Sea region and other areas.

\section{AB 32 - Air Resources Board - State of California}

California enacted AB 32 in 2006. The law requires the state to reduce its carbon emissions to $15 \%$ below 1990 levels by 2020 and to $80 \%$ below 1990 emissions by $2050 .^{117}$

The law directs the CARB to develop regulations for achieving this goal. It authorized CARB to create a cap-and-trade program as a market-based platform for reducing aggregate emissions cost effectively. In 2014, California linked its emission program with Quebec and published the first update to their AB 32 compliance plan. ${ }^{118}$ The plan prioritizes reductions in emissions from electric utilities and calls on the utility sector to reach near zero GHG emissions by 2050.

To implement the emission goals of $\mathrm{AB} 32$, the state's energy agencies will develop rules to improve demand response and energy efficiency participation, and to streamline interconnection processes for distributed generators. ${ }^{119}$

\section{Utility Procurement Policies}

In line with the state's emphasis on renewable generation to meet electricity load, California has enacted three other policies that incentivize or address impacts of higher renewable generation on the grid.

\section{Coal}

In 2003 the California Energy Commission (CEC), CPUC, and California Consumer Power and Conservation Financing Authority developed a joint priority system to evaluate new generation

\footnotetext{
${ }^{115}$ SB 14 initially proposed in 2009 would have required utilities to procure renewable energy from only sources within the state and this policy was vetoed by then Governor Schwarzenegger. http://leginfo.ca.gov/pub/09-10/bill/sen/sb 0001-0050/sb 14 vt 20091012.html.

${ }^{116}$ See Table 25 page 326 http://www.energy.ca.gov/2013publications/CEC-100-2013-001/CEC-100-2013-001-CMF-small.pdf.

${ }^{117}$ See bill here: http://www.leginfo.ca.gov/pub/05-06/bill/asm/ab 0001-0050/ab 32 bill 20060927 chaptered.html. The long term 2050 goal is based upon Governor Brown's Executive Order S-3-05: http://gov.ca.gov/news.php?id=1861.

${ }_{118} \mathrm{http} / /$ www.arb.ca.gov/cc/scopingplan/2013 update/first_update climate change_scoping_plan.pdf.

${ }_{119119} \mathrm{http} / / /$ www.arb.ca.gov/cc/scopingplan/2013 update/first update climate change scoping plan.pdf.
} 
decisions. This system is referred to as the loading order and it prioritizes energy efficiency, demand response, and renewable generation over fossil fuel generation.

In 2006, the California legislature passed SB 1368 that set carbon emission performance

standards for any California utility's owned or contracted baseload electricity generation. ${ }^{120}$ The legislature determined that utilities could only contract with, invest in, or construct baseload generation sources that produce electricity at or below the carbon emission rate of a combinedcycle natural gas plant. The bill, in essence, precludes any future utility investment in coal-fired generation, unless it employs carbon capture and sequestration CCS technology or some other emission control technology.

\section{Storage}

Cost-effective electricity storage could marginally improve the demand for PV relative to the demand for baseload renewables such as geothermal. The California legislature enacted AB 2514 in 2010 to address the presence of more variable generation on the grid. The law requires the CPUC to evaluate the role energy storage systems can play in the broader market and if deemed appropriate develop procurement targets for each IOU to achieve by 2016 and $2021 .^{121}$ The CPUC responded by requiring Pacific Gas and Electric (PG\&E), SCE, and SDG\&E to procure a combined total of $1,325 \mathrm{MW}$ of energy storage by 2020 , with installations no later than $2024 .^{122}$

The CPUC has set storage solicitation goals for the 2014 to 2016 biennial at $16 \mathrm{MW}$ for SCE and SDG\&E, along with an 80.5 MW goal for PG\&E. ${ }^{123}$ Whether the utilities meet these targets, and at what cost, will be in part contingent upon the slope of cost declines for battery storage. ${ }^{124}$ Nevertheless, SCE has procured over $261 \mathrm{MW}$ of battery storage that can be employed to achieve their mandated targets, which is significantly more than their biennial requirement. ${ }^{125}$ If this trend continues, the CPUC may be inclined to support more renewable capacity to serve load requirements.

\section{San Onofre Generating Station Retirement}

In 2012, SCE, the operator of the San Onofre Generating Station (SONGS), identified a small radioactive steam leak and a systemic weakening of tubing within its newly installed steam generator system. ${ }^{126} \mathrm{SCE}$ announced the early retirement of both units at SONGS in June 2013. ${ }^{127}$ CAISO has identified the retirement of SONGS as a risk to local reliability in the Los Angeles Basin. This retirement has significantly reduced system reserve margins across the Los Angeles Basin, enhancing the risk of service outages under heavy load conditions. ${ }^{128}$ Service outages would be even more likely, in the event critical regional high-voltage transmission lines went out of service, resulting in deficient voltage levels. Finally, in the absence of SONGS, some

\footnotetext{
${ }^{120}$ Access the bill here: http://www.energy.ca.gov/emission_standards/documents/sb_1368_bill_20060929_chaptered.pdf.

${ }^{121}$ See bill here: http://www.leginfo.ca.gov/pub/09-10/bill/asm/ab_2501-2550/ab_2514_bill_20100929_chaptered.html. The law allowed public

utilities to develop their own procurement plans if they determined that energy storage would be cost effective.

${ }^{122}$ See the decision here: http://docs.cpuc.ca.gov/PublishedDocs/Published/G000/M079/K533/79533378.PDF.

${ }^{123} \mathrm{http}: / /$ docs.cpuc.ca.gov/PublishedDocs/Published/G000/M127/K426/127426247.PDF.

${ }_{124}$ Wolff, Eric (2014). "Cheaper batteries from Tesla could transform the grid.” SNL Financial Inc. www.snl.com.

${ }^{125}$ https://www.sce.com/wps/portal/home/procurement/solicitation/lcr/!ut/p/b0/04_Sj9CPykssy0xPLMnMz0vMAfGjzOK9PF0cDd1NjDz9nQxdD RyDPS1cXD1cDYL9zfQLsh0VAQ4EJ6E!/.

${ }^{126}$ http://articles.latimes.com/2013/jun/07/local/la-me-0608-san-onofre-20130608. http://latimesblogs.latimes.com/lanow/2012/02/san-onofrepower-plant-leak.html.

${ }_{127}$ http://www.songscommunity.com/news2013/news060713.asp.

${ }^{128}$ http://www.caiso.com/Documents/BriefingSummer2012OperationsPreparedness-Presentation-Mar2012.pdf.
} 
local transmission lines could be overloaded. ${ }^{129}$ It should also be noted that the SONGS financial settlement along with natural gas replacement of SONGS is currently under review, investigation, and potential litigation.

To address these reliability concerns, the CPUC recently approved a plan to allow SCE and SDG\&E to procure up to 3,300 MW of new generation. ${ }^{130}$ The plan allows these utilities to procure a significant majority of this capacity from natural gas generators. Given the reliability benefits associated with geothermal generation, it is possible that these utilities might consider this generation in their procurement decisions. ${ }^{131}$ We discuss the renewable generation component in the regional utility planning section below.

\section{Once-Through Cooling}

Though generally unrelated to these carbon and renewable integration policies, California's decision to regulate the cooling systems employed across the utility sector will also influence the overall market.

In 2010, the State Water Resources Control Board (SWRCB) approved a once through cooling phase out plan that impacted 19 power plants with a combined operating capacity over 17,500 MW. ${ }^{132}$ SWCRB found that dry cooling systems were the best available technology and established this as the benchmark for compliance. ${ }^{133}$ SWCRB phased in compliance with this regulation from 2010 through 2029 in order to reduce potential reliability impacts associated with installing new cooling systems, or utility decisions to retire certain plants.

Several obligated plants have since been retired, but in general, most plant owners have suggested they plan to retrofit their plants. ${ }^{134}$ The Diablo Canyon Nuclear Plant is one example, though there has been controversy surrounding whether the costs associated with compliance are justified. ${ }^{135}$ As a result, the future of the plant's 2,200 MW of generation is unclear. If the plant is retired, the CPUC may offer a similar procurement decision to that of SONGS, which could promote some expansion in renewable generation.

\section{Demand Drivers: Arizona}

Arizona has an RPS for utilities under state regulation. The interim goal for 2013 (the most recent compliance reports) was $4 \%$ of retail sales, gradually increasing each year to $15 \%$ of sales in 2025 . The RPS requires $30 \%$ of each year's requirement to come from distributed resources, so the RPS-related demand for which Salton Sea resources will compete is $10.5 \%$ of retail sales by 2025 . Salt River Project, the state's largest non-jurisdictional utility, has voluntarily adopted a comparable renewable energy goal.

\footnotetext{
${ }^{129} \mathrm{http}: / /$ www.caiso.com/Documents/2014SummerAssessment.pdf.

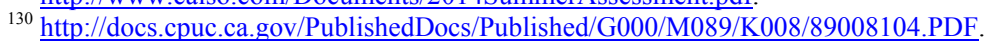

${ }^{131}$ In 2014, legislators proposed SB 1139, which sought to require IOUs to leverage the reliability benefits of geothermal generation, but the bill

did not pass. See bill language here: http://leginfo.legislature.ca.gov/faces/billNavClient.xhtml?bill_id=201320140SB1139.

${ }_{132}^{132} \mathrm{http} / / /$ www.energy.ca.gov/renewables/tracking_progress/documents/once through cooling.pdf.

${ }_{133}$ This was in part based on a 2006 CEC study on this issue, see Maulbetsch, J.S. and DiFilippo, M.N. (2006). Cost and Value of Water Use at Combined-Cycle Power Plants. http://www.energy.ca.gov/2006publications/CEC-500-2006-034/CEC-500-2006-034.PDF.

${ }^{134} \mathrm{http}: / /$ www.energy.ca.gov/renewables/tracking progress/documents/once through cooling.pdf.

135 “SDG\&E seeks to skip competitive bidding with Carlsbad power purchase deal." SNL Financial Inc. (2014), www.snl.com.
} 
In 2013, both of the state's largest IOUs-APS and Tucson Electric Power (TEP)—were ahead of schedule with respect to both total renewable energy procurement and the carve-out for distributed generation. APS procurements came to $6.8 \%$ of sales, while TEP's came to $5.6 \%$.

\section{Regional Utility Planning}

Integrated resource plans (IRP) indicate how utilities read and respond to short-term trends in supply and demand. This section examines the current IRPs of five California utilities: PG\&E, SCE, LADWP, SDG\&E, and IID. For the Arizona market, we evaluate the IRPs from the three largest utilities in the state: APS, SRP, and TEP.

Many of utilities expect to retire or discontinue purchase agreements with a portion of coal generation. Most of the replacement power is expected to come from renewables and natural gas resources, with much of the new renewable capacity directed towards compliance with state RPS requirements.

Most of the renewable procurements identified in utility IRPs are new solar photovoltaic capacity (Figure B7). Apart from unspecified renewable procurements, new storage capacity is a distant second, driven largely by $\mathrm{AB} 2510$. Planned geothermal procurements are about $9 \%$ the size of planned solar procurements in terms of nameplate capacity.

Many of the planned solar procurements are associated with specific projects. Projects near the Salton Sea could compete for much of the demand not yet awarded, provided there is sufficient transmission capacity within a reasonable proximity. Arizona utilities could conceivably buy Salton Sea solar power, but as detailed in the previous discussion about supply, they are unlikely to be economically competitive with Arizona's in-state solar resources. Salton Sea geothermal projects may be competitive in Arizona as baseload renewable power, however, as SRP in Arizona is a current buyer of geothermal power from the Salton Sea's 50 MW Hudson Ranch plant. 


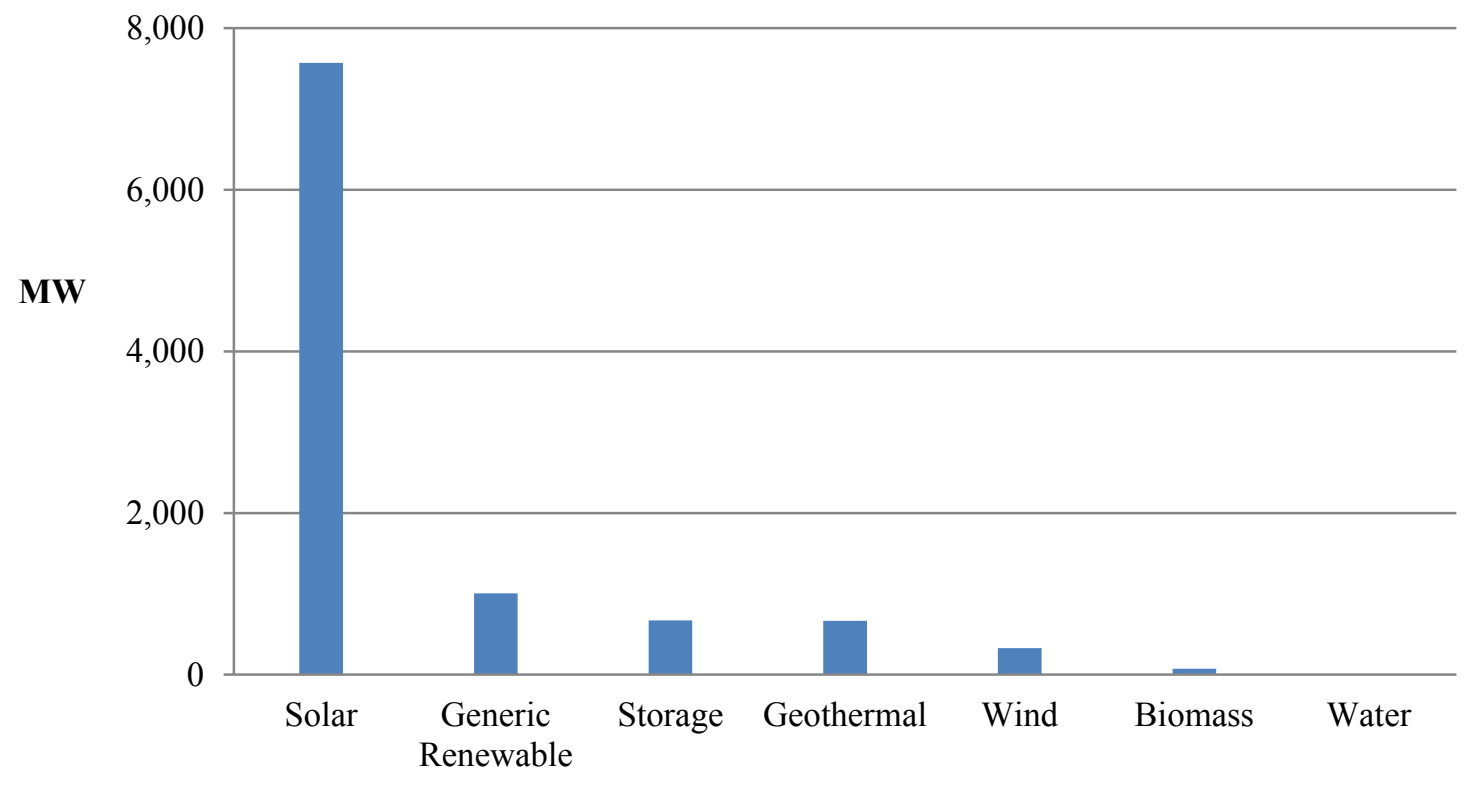

Fuel Type

Sources: PG\&E, SCE, LADWP, SDG\&E, and IID Integrated Resource Plans

Figure B7. Regional renewable planned capacity expansion based on current IRPs.

Though most of these utilities are expecting to meet RPS requirements through increased solar capacity, some intend to add geothermal capacity. Of these, about half of the expected new capacity is associated with planned projects (IID, SCE, and SRP), while the Salton Sea region could serve the remaining $250 \mathrm{MW}$ of new geothermal capacity sought by APS and LADWP. However, these utilities do not expect to procure new geothermal until 2020-2025.

\section{Pacific Gas \& Electric}

PG\&E is the largest electric utility in the state of California ${ }^{136}$ with 5.1 million electricity customers across the northern and central portions of the state. ${ }^{137}$ PG\&E expects load to increase to about $23,000 \mathrm{MW}$ by 2020 .

The utility anticipates adding $855 \mathrm{MW}$ of net new contracted renewable capacity to its fleet, but PG\&E notes that it expects to be short about 597 GWhs of RPS eligible renewable generation by 2020. The utility has since put out a solicitation for up to $1,600 \mathrm{GWhs}$ per year of renewable generation for RPS compliance. ${ }^{138}$

Most of PG\&E's procurement historically has been from solar. ${ }^{139}$ Of the projects expected to come online through 2020, none are located in either Imperial or Riverside counties. ${ }^{140}$

\footnotetext{
${ }^{136} \mathrm{http}: / /$ www.eia.gov/electricity/state/california/xls/sept03ca.xls.

$137 \mathrm{http} / / /$ www.pge.com/en/about/company/profile/index.page.

${ }^{138}$ http://www.pge.com/includes/docs/pdfs/b2b/wholesaleelectricsuppliersolicitation/RPS2014/RPS Solicitation_Protocol 01052015.pdf.

${ }^{139}$ See http://www.cpuc.ca.gov/NR/rdonlyres/A00F02FF-B55F-40AF-AECF-

AA258DD74378/0/RPS_Project_Status Table_2014_November.xls. And

http://www.pge.com/en/myhome/saveenergymoney/cleanenergyca/newsroom/article/toputility.page.

${ }^{140} \mathrm{http}$ ://www.cpuc.ca.gov/NR/rdonlyres/A00F02FF-B55F-40AF-AECF-AA258DD74378/0/RPS_Project_Status_Table_2014_November.xls.
} 


\section{Southern California Edison}

SCE is the second largest electric utility in California ${ }^{141}$ serving about 5 million electric customers across southern California. ${ }^{142} \mathrm{SCE}$ does not disclose its current load in its long term procurement plan, but it does expect its capacity need to increase from about 10,900 MW in 2015 to 13,739 MW by $2021^{143}$

In response to the retirement of SONGS and local transmission constraints, the CPUC authorized SCE to procure up to 2,500 MW of new capacity through $2021 .{ }^{144} \mathrm{SCE}$ has since signed contracts for a total of 2,220 MW including 1,700 MW of natural gas, $261 \mathrm{MW}$ of energy storage, $211 \mathrm{MW}$ of demand response, and $50 \mathrm{MW}$ of solar. ${ }^{145,146}$

Even though storage performed well in this capacity solicitation, SCE expects to meet much of its RPS requirements through solar resources. Currently, SCE has over 3,000 MW of prospective solar projects pending approval from the CPUC. ${ }^{147}$ In comparison, SCE intends to procure 225 MW of new geothermal capacity, through its recent power purchase agreement with the geothermal Geysers Plant. Despite this addition, SCE anticipates that geothermal as a percentage of its renewable generation mix will decline over its planning period. ${ }^{148}$

It is likely that SCE will require more renewable generation ${ }^{149}$ to meet future RPS obligations, though it is unclear when they will procure it. ${ }^{150}$ Solar from the Salton Sea region could compete for a part of SCE's future needs. ${ }^{151}$

\section{Los Angeles Department of Water and Power}

LADWP is the third largest utility in California ${ }^{152}$ with 3.8 million electric customers in the Los Angeles metropolitan area. ${ }^{153}$ LADWP served a load of 5,680 MW in 2014 and they expect this to increase to 7,065 MW by 2034 .

LADWP intends to procure over 2,000 MW of new renewable energy capacity through 2034. This generation will position the utility to meet $40 \%$ of total demand with renewable resources by 2030. LADWP expects much of this new capacity to be sourced from solar, with a near-term goal of $800 \mathrm{MW}$ of local solar by 2023. In the event this local solar expansion can be

\footnotetext{
${ }^{141} \mathrm{http}: / /$ www.eia.gov/electricity/state/california/xls/sept03ca.xls.

$142 \mathrm{http} / / /$ www.edison.com/content/dam/eix/documents/investors/sec-filings-financials/c8189 EIX-SCE 2013 10K As Filed 2481.pdf.

143 http://www.cpuc.ca.gov/NR/rdonlyres/8AB05FC4-80D3-4679-AC09-

41EABDA5131B/0/SCE2010LTPP2AB57BundledProcurementPlanAppendices_PUBLIC.pdf.

${ }_{144}$ http://docs.cpuc.ca.gov/PublishedDocs/Published/G000/M089/K008/89008104.PDF.

${ }^{145}$ https://www.sce.com/wps/portal/home/procurement/solicitation/lcr/!ut/p/b0/04_Sj9CPykssy0xPLMnMz0vMAfGjzOK9PF0cDd1NjDz9nQxdD RyDPS1cXD1cDYL9zfQLsh0VAQ4EJ6E!/.

${ }^{146} \mathrm{https}: / \mathrm{www}$. sce.com/wps/portal/home/procurement/solicitation/lcr/!ut/p/b0/04_Sj9CPykssy0xPLMnMz0vMAfGjzOK9PF0cDd1NjDz9nQxdD RyDPS1cXD1cDYL9zfQLsh0VAQ4EJ6E!/.

${ }^{147} \mathrm{http} / / /$ www.cpuc.ca.gov/NR/rdonlyres/A00F02FF-B55F-40AF-AECF-AA258DD74378/0/RPS Project_Status_Table 2014_November.xls.

${ }_{148} \mathrm{http}: / /$ www.cpuc.ca.gov/NR/rdonlyres/8AB05FC4-80D3-4679-AC09-

41EABDA5131B/0/SCE2010LTPP2AB57BundledProcurementPlanAppendices PUBLIC.pdf.

${ }^{149} \mathrm{http} / / /$ www.cpuc.ca.gov/NR/rdonlyres/CA15A2A8-234D-4FB4-BE41-05409E8F6316/0/2014Q3RPSReportFinal.pdf.

${ }_{150}$ It is also possible that the utility could renew contracts, or repower existing renewable facilities, which could temper their demand for new capacity. http://www.cpuc.ca.gov/NR/rdonlyres/CA15A2A8-234D-4FB4-BE41-05409E8F6316/0/2014Q3RPSReportFinal.pdf.

${ }^{151}$ For example, SCE's largest planned project is the $406 \mathrm{MW}$ expansion at the existing Imperial Valley Solar PV Project in Imperial County, California. http://www.cpuc.ca.gov/NR/rdonlyres/A00F02FF-B55F-40AF-AECF-

AA258DD74378/0/RPS Project Status Table 2014_November.xls.

152 http://www.eia.gov/electricity/state/california/xls/sept03ca.xls.

153 https://www.ladwp.com/cs/idcplg?IdcService=GET_FILE\&dDocName=OPLADWPCCB419127\&

$\underline{\text { RevisionSelectionMethod=LatestReleased. }}$.
} 
implemented without adverse impacts on the grid, LADWP will look to procure more solar resources within its service territory.

Though LADWP expects to procure much of its renewable generation from solar, at current it expects to add $166 \mathrm{MW}$ of geothermal over its planning period. Of this capacity, $100 \mathrm{MW}$ is not yet associated with a project and developers in the Salton Sea region could be well situated to meet this demand. However, LADWP notes that this procurement goal could be reduced if solar costs decline and higher solar penetration does not pose a reliability risk. ${ }^{154}$ Thus, if LADWP's plans come to fruition, the utility may not represent a large market for Salton Sea generators either solar or geothermal.

\section{San Diego Gas \& Electric}

SDG\&E is the fourth largest utility in California, ${ }^{155}$ with 1.4 million electric customers across San Diego and Orange counties. ${ }^{156}$ SDG\&E anticipates a load requirement of 4,850 MW in 2015 and they expect this to increase to nearly $5,360 \mathrm{MW}$ by $2024 .^{157}$

SDG\&E was also impacted by the retirement of SONGS, and the CPUC granted SDG\&E the authority to procure an additional $500 \mathrm{MW}$ to $800 \mathrm{MW}$ of capacity by 2020 to replace SONGS. Of this generation, at minimum SDG\&E is required to procure $25 \mathrm{MW}$ of storage capacity, along with $175 \mathrm{MW}$ of additional preferred resources. The utility can then procure $600 \mathrm{MW}$ from any source, for which the utility has expressed interested in purchasing the electricity from the proposed natural gas-fired Carlsbad Energy Center $(636 \mathrm{MW})^{158}$.

Much of SDG\&E's current renewable mix is associated with solar generation and they expect to add an additional $275 \mathrm{MW}$ of solar to meet future RPS requirements. ${ }^{159}$ As noted, even if SDG\&E purchases Carlsbad, they may still procure up to $175 \mathrm{MW}$ of additional renewable capacity. ${ }^{160}$

SDG\&E currently has no geothermal in its procurement, and has given little indication it would procure geothermal resources to meet future needs, which would represent a departure from their recent practices. ${ }^{161}$ Historical practice suggests that SDG\&E may procure solar generation and projects from the Salton Sea region.

\section{Imperial Irrigation District}

IID is the sixth largest electric utility in the state of California with 145,000 customers across Riverside and San Diego counties. ${ }^{162}$ IID had a peak load requirement of 1,160 MW in 2013 and they expect load to increase to about 1,615 MW by 2033.

\footnotetext{
${ }^{154}$ https://www.ladwp.com/cs/idcplg?IdcService=GET_FILE\&dDocName=OPLADWPCCB419127\&

RevisionSelectionMethod=LatestReleased.

${ }^{155} \mathrm{http}: / / \mathrm{www}$. eia.gov/electricity/state/california/xls/sept03ca.xls.

$156 \mathrm{http} / / / \mathrm{www}$. sdge.com/aboutus.

157 https://www.sdge.com/sites/default/files/regulatory/PUBLIC-SDGE-Bundled-Plan.pdf.

158 "SDG\&E seeks to skip competitive bidding with Carlsbad power purchase deal." SNL Financial Inc. (2014), www.snl.com.

${ }^{159} \mathrm{https} / /$ www.sdge.com/sites/default/files/regulatory/PUBLIC-SDGE-Bundled-Plan.pdf.

${ }^{160}$ SDG\&E will make its final procurement decision in early 2016: http://www.sdge.com/all-source-2014-rfo.

${ }^{161} \mathrm{https}: / / \mathrm{www}$. sdge.com/sites/default/files/regulatory/PUBLIC-SDGE-Bundled-Plan.pdf.

162 http://www.iid.com/Modules/ShowDocument.aspx?documentid=9280.
} 
IID expects the retirement of its share in the coal-fired San Juan Generating Station to require $150 \mathrm{MW}$ of replacement baseload resources, which they anticipate will be sourced from a renewable project. IID expects that this project along with the addition of between $30 \mathrm{MW}$ and $50 \mathrm{MW}$ of geothermal and between $20 \mathrm{MW}$ and $60 \mathrm{MW}$ of solar in the 2017-2020 timeframe will keep them in compliance with their RPS requirements.

\section{Arizona}

Arizona is a key potential market for Salton Sea renewables because of its easy access. Most of the power on existing transmission across the Colorado River flows east-to-west into California; there is significant counterflow capability in the opposite direction that could accommodate sales to Arizona without major transmission additions.

APS is the largest retailer of electricity in Arizona ${ }^{163}$ with over 1.2 million customers. ${ }^{164}$ APS's service territory spans nearly 35,000 square miles across much of the central portion of the state. ${ }^{165}$ In 2014, APS served a load of 8,125 MW and they expect load to increase to over 12,980 MW by 2029.

APS plans add about $425 \mathrm{MW}$ of renewable energy through 2029 to remain in compliance with the Arizona RPS. ${ }^{166}$ Of this capacity, APS intends to add $242 \mathrm{MW}$ of solar, $150 \mathrm{MW}$ of geothermal, and $33 \mathrm{MW}$ of wind capacity. The utility did not link this capacity with specific projects or locations. It is likely given Arizona's strong solar resources and APS's procurement history that they would procure solar generation from in-state. ${ }^{167}$ APS could look to the Salton Sea for additional geothermal generation, and in fact already has one PPA in place for 11 MW. ${ }^{168}$ APS' IRP, however, does not anticipate procuring either until at the earliest 2023.

SRP is the second largest retail electricity provider in Arizona and the largest public utility in the state. ${ }^{169}$ SRP serves nearly one million customers across 3,000 square miles in the Phoenix Metropolitan area. ${ }^{170}$ In 2013, SRP had a peak load requirement of about 7,450 MW and they expect that to increase to about 7,700 MW by $2016 .{ }^{171}$

As a public utility, SRP is not required to comply with Arizona's RPS, but it has adopted a voluntary sustainable resource standard in which it has committed to meeting $20 \%$ of its retail load through renewable and energy efficiency resources by $2020 .{ }^{172}$ In SRP's 2012 IRP they suggested they would procure $156 \mathrm{MW}$ from renewable generation sources through 2016. SRP

\footnotetext{
${ }^{163}$ EIA (2013). Table 3. Top Five Retailers of Electricity, with End Use Sectors, 2012 Arizona. http://www.eia.gov/electricity/state/arizona/xls/sept03az.xls.

${ }^{164}$ See APS (2014). Integrated Resource Plan. http://www.aps.com/library/resource\%20alt/2014 IntegratedResourcePlan.pdf. Accessed 7/8/14.

${ }^{165}$ See APS (2014). Integrated Resource Plan. http://www.aps.com/library/resource\%20alt/2014_IntegratedResourcePlan.pdf. Accessed 7/8/14.

${ }^{166}$ APS (2014). Integrated Resource Plan. http://www.aps.com/library/resource\%20alt/2014_IntegratedResourcePlan.pdf. Accessed 7/8/14.

${ }^{167}$ APS (2014). Integrated Resource Plan. Accessed 7/8/14 from: http://www.aps.com/library/resource\%20alt/2014_IntegratedResourcePlan.pdf. See also SNL Financial Inc. www.snl.com. Accessed 7/8/14.

${ }^{168}$ CE Turbo.

${ }^{169}$ EIA (2013). Table 3. Top Five Retailers of Electricity, with End Use Sectors, 2012 Arizona. http://www.eia.gov/electricity/state/arizona/xls/sept03az.xls.

${ }^{170}$ SRP (2014). 2014 SRP Annual Report: http://www.srpnet.com/about/financial/pdfx/AnnualReport-FY2014 web.pdf.

${ }^{171}$ SRP (2012). Integrated Resource Plan FY 2013. http://ww2.wapa.gov/sites/western/es/irp/Documents/SRP2013.pdf. Accessed 7/21/14.

${ }^{172}$ SRP (2014). Resource Stewardship Sustainability Portfolio. http://www.srpnet.com/environment/earthwise/pdfx/ResourceStewardship.pdf.
} 
has since signed contracts to purchase $64 \mathrm{MW}$ of solar capacity within Arizona ${ }^{173}$ and $113 \mathrm{MW}$ of geothermal generation from two facilities one each in Utah ${ }^{174}$ and California. ${ }^{175}$

These planned projects will contribute to SRP's compliance with their sustainability goal, while diversifying SRP's renewable energy portfolio. ${ }^{176}$ It is unclear whether SRP will procure additional renewable generation to meet its goal at this time, so at least over the short term SRP may not be in the market for renewable generation from the Salton Sea region.

TEP is the third largest utility in Arizona ${ }^{177}$ and it serves 400,000 customers mainly across the Tucson metro area, in Pima County. ${ }^{178}$ TEP had a peak load requirement of nearly $2675 \mathrm{MW}$ in 2014 and they expect this to increase to about 3200 MW by 2028 .

To satisfy its RPS requirements, TEP expects to add $321 \mathrm{MW}$ of new renewable capacity by 2028, split between solar (227 MW) and wind (94 MW). TEP has already announced several projects slated to come online in 2015 that will help meet its RPS requirements, all of which are located in Arizona.

TEP has not announced projects associated with the remaining capacity (224 MW), which will primarily be sourced from solar generators $(181 \mathrm{MW})$. TEP has historically procured solar generation entirely within the state ${ }^{179}$ and we can expect that trend to continue. It is possible that TEP could source the remaining $43 \mathrm{MW}$ of wind from developers in the Salton Sea region, but they do not expect to procure this wind generation until 2023-24. Therefore, TEP will likely not procure renewable generation from the Salton Sea region until 2023 at the earliest, and it is uncertain how competitive wind generation from this region would be at that time.

\section{Transmission Capability from IID into CAISO}

Of the 768 MW of the geothermal generation now operating in the Salton Sea area, about twothirds is under contract to Southern California Edison and uses most of the transfer capability from IID into CAISO. The permanent retirement of SONGS and the resulting local reliability issues temporarily limited transfer capability even further, but CAISO projects that recommended mitigations and the approved projects in Southern California area will restore overall deliverability from IID to what it was before SONGS retirement.

In its draft transmission plan for 2014 and 2015, CAISO estimates that existing transmission and upgrades under way can accommodate between $500 \mathrm{MW}$ and $750 \mathrm{MW}$ of new generation from IID into southern California, after taking into account generation in IID that is already connected to the CAISO system or is under construction. In addition, based on discussion with IID, there is currently $900 \mathrm{MW}$ of capacity on Path 42, and significant deliverability out of the IID BA.

\footnotetext{
${ }^{173}$ Harelson, Scott (2014). SRP Signs Deal with sPower for Solar Energy Facility near Florence. http://www.srpnet.com/newsroom/releases/112014.aspx.

${ }^{174}$ SRP (2014). Third Quarter Report SRP Fiscal Year 2014. http://www.srpnet.com/about/financial/pdfx/FY2014/ 3rdOtrRpt FY2014.pdf. The Cove Fort facility is in early development and SNL Financial does not have a confirmed operation date for the plant.

${ }^{175}$ SRP (2014). Resource Stewardship Sustainability Portfolio. http://www.srpnet.com/environment/earthwise/pdfx/ResourceStewardship.pdf.

${ }^{176}$ SRP (2014). Resource Stewardship Sustainability Portfolio. http://www.srpnet.com/environment/earthwise/pdfx/ResourceStewardship.pdf.

${ }^{177}$ EIA (2013). Table 3. Top Five Retailers of Electricity, with End Use Sectors, 2012 Arizona.

http://www.eia.gov/electricity/state/arizona/xls/sept03az.xls.

${ }^{178}$ TEP (2014). Tucson Electric Power 2014 Integrated Resource Plan. https://www.tep.com/doc/planning/2014-TEP-IRP.pdf. Accessed 7/7/14.

${ }^{179}$ See TEP (2014). Tucson Electric Power 2014 Integrated Resource Plan. https://www.tep.com/doc/planning/2014-TEP-IRP.pdf and SNL

Financial Inc. data www.snl.com. Accessed 7/7/14.
} 
CAISO also conducted a limited information-only assessment of two recently proposed projects, and concluded that they might accommodate as much as $2,500 \mathrm{MW}$ of renewable generation. ${ }^{180}$

\section{Competitive Edge of Salton Sea Renewables}

The Salton Sea area could be a source of renewable power in both the California and Arizona markets, but it is unlikely to have any economic headroom to accommodate the additional revenue burden of Salton Sea reclamation. Developing geothermal and solar projects in the Salton Sea area tends to be more expensive than the same technologies developed in Arizona or Nevada. This is due largely to differences in the cost of labor, taxes, and other expenses that tend to be higher in the state of California. ${ }^{181}$ Policies favorable to renewable energy could create a unique benefit to development within the region. These could include utilizing the North American Development Bank for development expertise and to leverage interest rate cost savings, streamlining permitting requirements, and providing certainty surrounding environmental permitting costs. Additional potential developments which could affect these findings include the implementation of more aggressive in-state renewable energy capacity goals, and additional project cost declines uniquely benefitting the Salton Sea region (i.e., local incentives, exceptional transmission access).

While the Salton Sea has abundant solar resources with potentially high productivity, so too do competing areas in California, Arizona and Nevada. Global horizontal irradiance is about the same across the three-state region from Las Vegas, NV down to Yuma, AZ, so the amount of energy produced for every megawatt of installed capacity is equally high. ${ }^{182}$ Cost per megawatt of installed capacity is likely to be lower in Arizona, putting Salton Sea PV at an economic disadvantage in that market relative to in-state solar. While cost reductions are trending toward parity with natural gas on an LCOE basis around 2020 (if not sooner), these improvements will help competing solar areas just as much as they will help Salton Sea.

The Arizona market may be friendlier to Salton Sea geothermal because it has no significant geothermal resource potential of its own. Transmission access - as counterflow on the EHV path between Imperial and Phoenix - could also favor Salton Sea geothermal in serving Arizona load. Even if it is easier to reach, however, the Arizona market could be softer. The largest utilities seem to be ahead of their RPS-related procurement needs. In addition, wholesale prices tend to be lower in Arizona than in California, which could exacerbate resistance to above-market costs.

\footnotetext{
${ }^{180}$ The projects are the Midway-Devers $500 \mathrm{kV}$ AC line project, and the Western Area Power Administration's Strategic Transmission Expansion Plan (STEP). Both were submitted in CAISO's 2014 request window.

${ }^{181}$ Energy and Environmental Economics, Capital Cost Review of Power Generation Technologies (final report and recommendations approved by WECC), March 2014, Table 33 (https://www.wecc.biz/Reliability/2014_TEPPC_Generation_CapCost_Report_E3.pdf).

${ }^{182}$ NREL, Solar Power Prospector (geographic information system mapping tool), “Avg. annual GHI," queried March 2015.
} 


\section{Appendix C: Revenue Potential Calculations}

Table C1. Potential Revenue under Current Conditions

\begin{tabular}{l} 
Potential \\
Revenue \\
under Current \\
Conditions \\
\hline Geothermal \\
(IID KGRA) \\
Offshore (low) \\
\hline Geothermal \\
(IID KGRA) \\
Offshore (high) \\
\hline Geothermal \\
(IID KGRA) \\
Offshore (low) \\
\hline Geothermal \\
(IID KGRA) \\
Offshore (high) \\
\hline AB 1471 (CA \\
2014 Water \\
Bond)
\end{tabular}

\begin{tabular}{|l|c|c|c|c|c|c|}
\hline Estimate & $\begin{array}{c}\text { Cap. } \\
\text { Factor }\end{array}$ & $\begin{array}{c}\text { PPA } \\
\text { price } \\
\text { (low) }\end{array}$ & $\begin{array}{c}\text { PPA } \\
\text { price } \\
\text { (high) }\end{array}$ & $\begin{array}{c}\text { GW } \\
\text { Cap. } \\
\text { (low) }\end{array}$ & $\begin{array}{c}\text { GW } \\
\text { Cap. } \\
\text { (high) }\end{array}$ & $\begin{array}{c}\text { Lease rate \% } \\
\text { royalties }\end{array}$ \\
\hline
\end{tabular}

Revenue Potential Calculation= Capacity factor X 8760 X GW Capacity X 1000 X PPA Price (MWh) X Lease rate

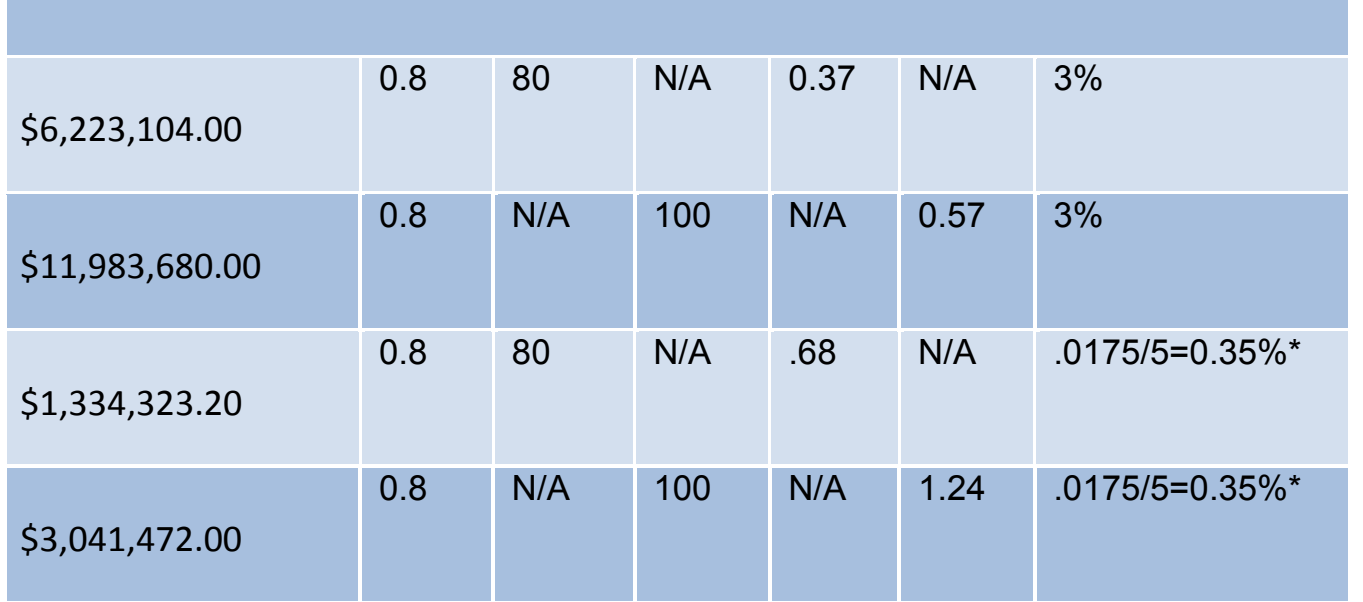

Total CA water bond is $\$ 475 \mathrm{M}$, $\$ 200 \mathrm{M}$ assumed as upper limit given other liabilities within water bond. $\$ 200,000,000 / 14=\$ 14,285,714.29$

* For all geothermal leases issued after the passage of the EPAct 2005, there is a required $1.75 \%$ royalty rate of the gross proceeds for the first ten years of production, which increases to $3.75 \%$ afterwards. Currently, $20 \%$ of these royalties are allocated to the project county. Given the required development and construction period for geothermal projects, and study period through 2030, the initial 10-year royalty rate was assumed. See section 5.5 .1 for additional detail. 
Table C2. Potential Revenue under Future Conditions

\begin{tabular}{|c|c|c|c|c|c|c|c|c|}
\hline & Estimate & $\begin{array}{l}\text { Cap. } \\
\text { Factor }\end{array}$ & $\begin{array}{l}\text { PPA } \\
\text { price } \\
\text { (low) }\end{array}$ & $\begin{array}{l}\text { PPA } \\
\text { price } \\
\text { (high) }\end{array}$ & $\begin{array}{l}\text { Acre } \\
\text { age }\end{array}$ & $\begin{array}{l}\text { Acre/M } \\
\text { W }\end{array}$ & $\begin{array}{l}\text { GW } \\
\text { Cap. }\end{array}$ & $\begin{array}{l}\text { Lease } \\
\text { rate } \% \\
\text { royalty }\end{array}$ \\
\hline $\begin{array}{l}\text { Potential } \\
\text { Revenue under } \\
\text { Future } \\
\text { Conditions }\end{array}$ & \multirow{2}{*}{\multicolumn{8}{|c|}{$\begin{array}{l}\text { Revenue Potential Calculation= } \\
\text { Capacity factor X } 8760 \times \text { GW Capacity X } 1000 \times \text { PPA Price (MWh) X Lease rate } \\
\text { Capacity Calculation= (Acreage/ Acre/MW) } / 1000 \\
\$ 0 \mathrm{M} \text { assumes that mineral recovery from geothermal brines does not reach } \\
\text { commercialization by } 2030 \text {. } \\
\$ 25.8 \mathrm{M} \text { assumes that mineral recovery from geothermal brines reaches } \\
\text { commercialization by } 2030 \text {, and that revenues from plant operations are sufficient to } \\
\text { accommodate a } 3 \% \text { IID geothermal royalty rate on gross proceeds (the current land } \\
\text { lease royalty rate assessed on gross PPA proceeds of geothermal plants). } \\
\text { See section } 4.2 .1 \text { for full calculation. }\end{array}$}} \\
\hline $\begin{array}{l}\text { Mineral recovery } \\
\text { from geothermal } \\
\text { brines (offshore } \\
\text { KGRA) } \\
\text { (Low-High) }\end{array}$ & & & & & & & & \\
\hline $\begin{array}{l}\text { Algal biofuels } \\
\text { (offshore non- } \\
\text { KGRA)* }\end{array}$ & \multicolumn{8}{|c|}{$\begin{array}{l}\$ 1.2 \text { to } 2.3 \mathrm{M} \text {. Assumes } \$ 3 / \text { gal cost competiveness by } 2030,1-2 \% \text { IID land lease } \\
\text { rate: } \\
\text { Low: } \$ 3 / \text { gal } X 39,000,000 \text { gallons } \times .01=\$ 1,170,000 \\
\text { High: } \$ 3 / \text { gal } X 39,000,000 \text { gallons } X .02=2,340,000\end{array}$} \\
\hline $\begin{array}{l}\text { Salinity Gradient } \\
\text { Solar Ponds } \\
\text { (offshore non- } \\
\text { KGRA)* (Low) }\end{array}$ & $\$ 630,720$ & 0.9 & 80 & $\mathrm{~N} / \mathrm{A}$ & $\mathrm{N} / \mathrm{A}$ & $\mathrm{N} / \mathrm{A}$ & 0.1 & $1 \%$ \\
\hline $\begin{array}{l}\text { Salinity Gradient } \\
\text { Solar Ponds } \\
\text { (offshore non- } \\
\text { KGRA)* (High) }\end{array}$ & $\$ 1,576,800$ & 0.9 & $\mathrm{~N} / \mathrm{A}$ & 100 & N/A & $\mathrm{N} / \mathrm{A}$ & 0.1 & $2 \%$ \\
\hline $\begin{array}{l}\text { Solar PV } \\
\text { (offshore non- } \\
\text { KGRA) (Low) } \\
\end{array}$ & $\$ 1,022,663$ & .232 & 40 & $\mathrm{~N} / \mathrm{A}$ & 9,938 & 7.9 & 1.258 & $1 \%$ \\
\hline $\begin{array}{l}\text { Solar PV } \\
\text { (offshore non- } \\
\text { KGRA) (High) }\end{array}$ & $\$ 3,067,990$ & .232 & $\mathrm{~N} / \mathrm{A}$ & 60 & 9,938 & 7.9 & 1.258 & $2 \%$ \\
\hline $\begin{array}{l}\text { Solar PV (onshore } \\
\text { BLM SEZ) (Low) }\end{array}$ & $\$ 1,463,270$ & .232 & 40 & $\mathrm{~N} / \mathrm{A}$ & N/A & $\mathrm{N} / \mathrm{A}$ & 1.8 & $1 \%$ \\
\hline $\begin{array}{l}\text { Solar PV (onshore } \\
\text { BLM SEZ) (High) }\end{array}$ & $\$ 4,389,811$ & .232 & N/A & 60 & N/A & N/A & 1.8 & $2 \%$ \\
\hline $\begin{array}{l}\text { Desert Renewable } \\
\text { Energy } \\
\text { Conservation Plan } \\
\text { - Habitat } \\
\text { Restoration }\end{array}$ & \multicolumn{8}{|c|}{$\begin{array}{l}\text { DRECP revenues were calculated based on the Draft DRECP non-acquisition } \\
\text { mitigation cost estimates from Table } 23 \text { EIR/EIS Appendix I, } 2014 \text {. These costs } \\
\text { were given as net-present values, and were undiscounted in order to ensure equal } \\
\text { comparison with the other potential revenues. The DRECP nominal discount rate } \\
\text { (excluding inflation) is } 3.6 \% \text { over a } 25 \text { year period. } \\
\text { Low estimate calculated based on a pro-rata allocation of the Imperial County } \\
\text { Habitat Restoration costs. This pro-rata allocation was based on the proportion of } \\
\text { acreage allocated to the endangered pupfish, compared to the total habitat } \\
\text { restoration acreage for all species ( } 8,000 / 47,000)=17 \% \\
\text { The high estimate assumes that the full Imperial and Riverside County Habitat } \\
\text { Restoration costs were allocated to Salton Sea restoration efforts. }\end{array}$} \\
\hline
\end{tabular}




\section{References}

Agha, K. R., "The thermal characteristics and economic analysis of a solar pond coupled low temperature multistage desalination plant," Solar Energy, 83, 501-510, (2009).

Al-Karaghouli, A., and Kazmerski, L.L., Energy consumption and water production cost of conventional and renewable-energy powered desalination processes. Renewable and Sustainable Energy Reviews, (2013).

Ashwood, A. and D. Bharathan, Hybrid Cooling Systems for Low-Temperature Geothermal Power Production. National Renewable Energy Laboratory: NREL/TP-5500-48765; (2011).

Balta, M. T., Dincer, I., \& Hepbasli, A., Thermodynamic assessment of geothermal energy use in hydrogen production. International Journal of Hydrogen Energy, 2009.

Balta, M. T., Dincer, I., and Hepbasli, A., Potential methods for geothermal-based hydrogen production. International Journal of Hydrogen Energy, 35(10), 4949-4961, 2009.

Billman W. J., Brown L. A, Zaki M., Eccentric Tool Increases Liner Size Capacity in Challenging Salt Dome Application Allowing Longest Horizontal Well in Gulf of Suez, Society of Petroleum Engineers (2000).

Bolinger, M., and S. Weaver, “Utility-Scale Solar 2012,” LBNL-6408E, Lawrence Berkeley National Laboratory, September 2013.

Boucier, W. L., M. Lin, and G. Nix, Recovery of Mineral and Metals from Geothermal Fluids. Lawrence Livermore National Laboratory; UCRL-CONF-215135, (2003).

Bronicki, L., Innovative Geothermal Power Plants: Fifteen Years of Experience. Proceedings of the World Geothermal Congress: Florence, Italy, (1995).

Bujakowski W., B. Tomaszewska, B. Kepinska, and M. Balcer, Proceedings of the World Geothermal Congress: Bali, Indonesia, (2010).

Camacho, L. M., L. Dumée, J. Zhang, J. Li, M. Duke, J. Gomez, and S. Gray. "Advances in Membrane Distillation for Water Desalination and Purification Applications," Water, (2013).

Canadian Geothermal Energy Association (CanGEA), Direct Utilization of Geothermal Energy: Suitable Applications and Opportunities for Canada. Canadian Geothermal Energy Association, Calgary, Alberta, (2014).

CARB, An Evaluation of Fuel Cell Electric Vehicle Deployment and Hydrogen Fuel Station Network Development, California Environmental Protection Agency, Air Resources Board, http://www.carb.ca.gov/msprog/zevprog/ab8/ab8_report_final_june2014. pdf.

Colorado School of Mines, An Integrated Framework for Treatment and Management of Produced Water: Technical Assessment of Produced Water Treatment Technologies. Colorado School of Mines, Golden, Colorado, (2009). 
Corbus, D. Hurlbut, P. Schwabe, E. Ibanez, M. Milligan, G. Brinkman, A. Paduru, V. Diakov, and M. Hand, "California-Wyoming Grid Integration Study Phase 1-Economic Analysis", NREL/TP-6A20-61192, March 2014.

Davis, R., Fishman, D., Frank, E., et al., "Renewable Diesel from Algal Lipids: An Integrated Baseline for Cost, Emissions, and Resource Potential from a Harmonized Model," Argonne National Laboratory, ANL/ESDA/12-4 (2014).

EES Consulting, Salton Sea Revenue Potential Study Final, Imperial, California Imperial Irrigation District, (2013).

El-Housayni, K., and E. Wilkins, "Benefit Cost Analysis of Gel Solar Ponds," Energy Convers. Mgmt., 27, 219-236 (1987).

Geothermal Education Office (GEO). Direct (Non-Electrical) Uses of Geothermal Waters (2005). http://geothermal.marin.org/geoenergy.html.

Geothermal Energy Association, Geothermal Power: International Market Overview. Geothermal Energy Association, Washington, DC; (2013).

GeothermEx, Consultant Report: New Geothermal Site Identification and Qualification, California Energy Commission Public Interest Energy Research Program, (2004).

Green, E., Particulate Matters: Settling the Dust on Owens Dry Lakebed, Arid: A Journal of Desert Art, Design and Ecology (2014). http://aridjournal.com/particulate-matters-emily-green.

Heuberger J., Geothermal/Alternative Energy and Transmission Element County of Imperial General Plan, Imperial County Planning and Development Services Department, (2006). http://ods. od. nih. gov/factsheets/Selenium-HealthProfessional/.

Hulen, J., Kaspereit, D., Norton, D., Osborn, W. and Pulka, F.S., Refined Conceptual Modeling and a New Resource Estimate For the Salton Sea Geothermal Field, Imperial Valley, California Geothermal Resources Council Transactions (2002).

Jones K.L., Johnson P.D., Young S., Glotfelty, M., Jones, A.H., Imperial Irrigation District: Geothermal Resource Assessment, The Aerospace Corporation and Clear Creek Associates (2011).

Kagel, A., The State of Geothermal Technology - Part II: Surface Technology. Geothermal Energy Association, Washington, DC, (2008).

Kalina, A. New Thermodynamic Cycles and Power Systems for Geothermal Applications. Geothermal Resources Council Transactions, (2006).

Kanoglu, M., Dincer, I., and Rosen, M. (2007). Geothermal energy use in hydrogen liquefaction. International Journal of Hydrogen Energy, (2007). 
Kimber, A., Mitchell, L., Nogradi, S., Wenger, H., "The Effect of Soiling on Large GridConnected Photovoltaic Systems in California and the Southwest Region of the United States," Photovoltaic Energy Conversion, Conference Record of the 2006 IEEE 4th World Conference, May 2006.

Kuyumcu C., Solaroglu D. U., Akar S., Ipek B., A Directional Geothermal Well in Turkey: GK4 Case Study, GRC Transactions, (2012).

Mainomi A., Minerals Recovery from Salton Sea Geothermal Brines: A Literature Review and Proposed Cementation Process, Geothermics, (1982).

McCollum, D., Yang, C., Yeh, S., and Ogden, J., Deep greenhouse gas reduction scenarios for California - Strategic implications from the CA-TIMES energy-economic systems model.

Energy Strategy Reviews, (2012).

Melaina, M., and Bremson, J., Refueling Availability for Alternative Fuel Vehicle Markets: Sufficient Urban Station Coverage, Energy Policy, (2008).

Melaina, M., and Penev, M., (2013). Hydrogen Station Cost Estimates (No. NREL/TP-540056412). http://www. nrel. gov/docs/fy13osti/56412.pdf.

Melaina, M., and Webster, K., Role of Fuel Carbon Intensity in Achieving 2050 Greenhouse Gas Reduction Goals within the Light-Duty Vehicle Sector. Environmental Science \& Technology, (2011).

Milligan, M., Clark, K., King, J., Kirby, B., Guo, T., Liu, G., Examination of Potential Benefits of an Energy Imbalance Market in the Western Interconnection, (2013). http://www.nrel.gov/docs/fy13osti/57115.pdf.

Mines, G., Richard, C., Nathwani, J., Hanson, H., Wood, R., Geothermal Plant Capacity Factors, Proceedings, 40th Workshop on Geothermal Reservoir Engineering, Stanford University, Stanford, CA, (2015).

Ong, Sean, Land-Use Requirements for Solar Power Plants in the United States. Golden, Colorado (2013). http://www.nrel.gov/docs/fy13osti/56290.pdf.

Pacheco, J. E., "Final Test and Evaluation Results from the Solar Two Project," SAND20020120, (2002).

Pienkos, P.T., Laurens, L., and Aden, A. (2011). Making Biofuel from Microalgae," American Scientist, (2011).

Ranjan, K.R. and Kaushik, S.C., "Thermodynamic and economic feasibility of solar ponds for various thermal applications: A comprehensive review," Renewable and Sustainable Energy Reviews, 32, (2014).

Ruskowitz, J.A., Suárez, F., Tyler, S.W., Childress, A.E., Evaporation suppression and solar energy collection in a salt-gradient solar pond, Solar Energy, 2014. 
Sarver, T., A. Al-Qaraghuli, and L. L. Kazmerski, "A Comprehensive Review of the Impact of Dust on the Use of Solar Energy: History, Investigations, Results, Literature, and Mitigation Approaches," Science Undergraduate Laboratory Internship (SULI) report, National Renewable Energy Laboratory, September, 2012.

Sheehan, J., Dunahay, T., Benemann, J., and Roessler, P. A Look Back at the U.S. Department of Energy's Aquatic Species Program-Biodiesel from Algae, (1998).

http://www.nrel.gov/biomass/pdfs/24190.pdf.

Stephens, T., Transportation Energy Futures Series: Non-Cost Barriers to Consumer Adoption of New Light-Duty Vehicle Technologies (2013).

SunShot Vision Study, U.S. Department of Energy, DOE/GO-102012-3037, February 2012.

Turchi, C. S., M. J. Wagner, and C. F. Kutscher, "Water Use in Parabolic Trough Power Plants: Summary Results from WorleyParsons' Analyses," NREL/TP-5500-49468, December 2010.

U.S. Department of Defense, Strategic and Critical Materials 2013 Report on Stockpile Requirements, Report to Congress, January 2013.

http://mineralsmakelife.org/assets/images/content/resources/Strategic_and_Critical_Materials_20 13_Report_on_Stockpile_Requirements.pdf.

U.S. Fish \& Wildlife Service, Sonny Bono Salton Sea National Wildlife Refuge: Wildlife List (2008). http://www. fws.gov/saltonsea/pdf/SaltonSea WildlifeList'08. 6. pdf.

Wang, J. L., L. Zhao, and X. D. Wang, "A comparative study of pure and zeotropic mixtures in low-temperature solar Rankine cycle,” Applied Energy, 87, 3366-3373 (2010).

Wigmosta, M.S., Coleman, A.M., Skaggs, R.J., Huesemann, M.H. and Lane, L.J. National microalgae biofuel production potential and resource demand. Water Resources Research, (2011). http://www. algaebiomass. org/wp-content/uploads/2012/11/wigmostapalgae_resource2011.pdf. 